\title{
Effects of Natural and Human Factors on Groundwater Quality of Basin-Fill Aquifers in the Southwestern United States-Conceptual Models for Selected Contaminants
}

Volatile organic compounds

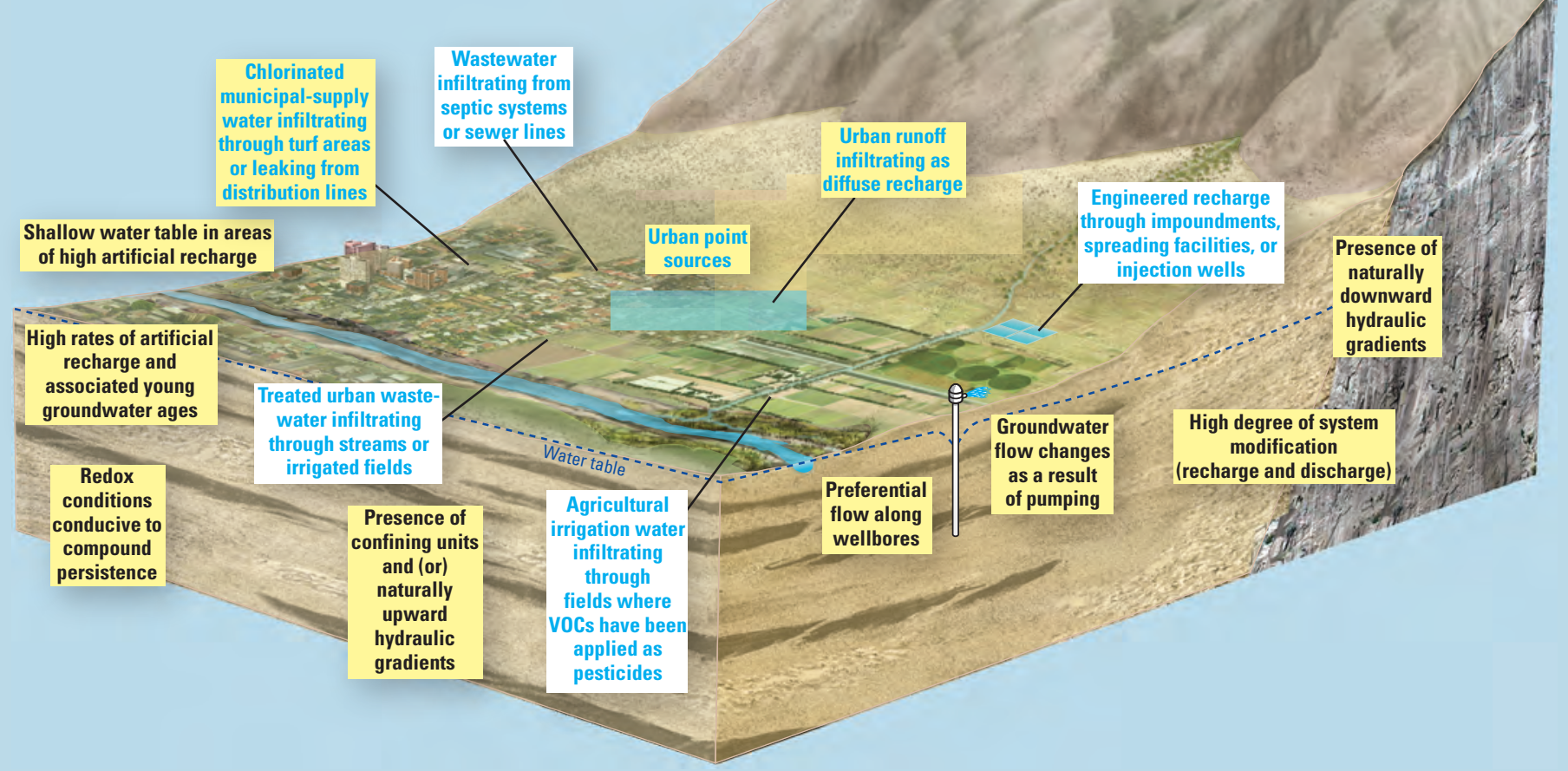

Scientific Investigations Report 2011-5020 
Cover: Illustrations of conceptual model of major natural and human factors affecting the vulnerability of Southwestern basin-fill aquifers to contamination with volatile organic compounds. 


\section{Effects of Natural and Human Factors on Groundwater Quality of Basin-Fill Aquifers in the Southwestern United States-Conceptual Models for Selected Contaminants}

By Laura M. Bexfield, Susan A. Thiros, David W. Anning, Jena M. Huntington, and Tim S. McKinney

National Water-Quality Assessment Program

Scientific Investigations Report 2011-5020 


\title{
U.S. Department of the Interior \\ KEN SALAZAR, Secretary
}

\section{U.S. Geological Survey \\ Marcia K. McNutt, Director}

\section{U.S. Geological Survey, Reston, Virginia: 2011}

\author{
For more information on the USGS — the Federal source for science about the Earth, its natural and living resources, \\ natural hazards, and the environment, visit http://www.usgs.gov or call 1-888-ASK-USGS \\ For an overview of USGS information products, including maps, imagery, and publications, \\ visit http://www.usgs.gov/pubprod \\ To order this and other USGS information products, visit http://store.usgs.gov
}

Any use of trade, product, or firm names is for descriptive purposes only and does not imply endorsement by the U.S. Government.

Although this report is in the public domain, permission must be secured from the individual copyright owners to reproduce any copyrighted materials contained within this report.

Suggested citation:

Bexfield, L.M., Thiros, S.A., Anning, D.W., Huntington, J.M., and McKinney, T.S., 2011, Effects of natural and human factors on groundwater quality of basin-fill aquifers in the southwestern United States - conceptual models for selected contaminants: U.S. Geological Survey Scientific Investigations Report 2011-5020, 90 p. 


\section{Contents}

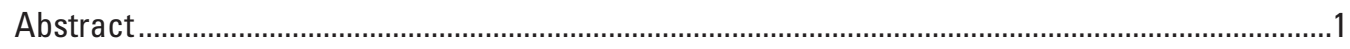

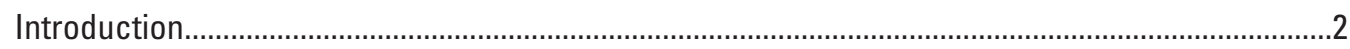

Background on the Southwest Principal Aquifers Study ......................................................

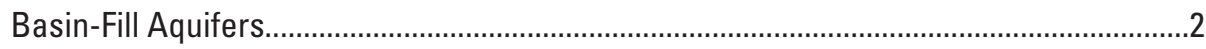

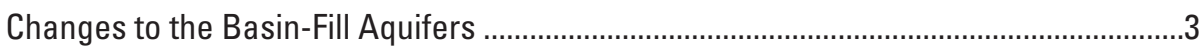

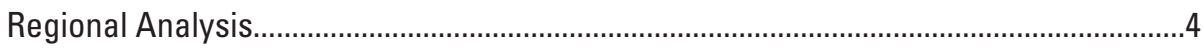

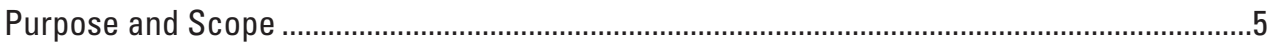

Previous Regional Investigations of Southwestern Basin-Fill Aquifers ....................................

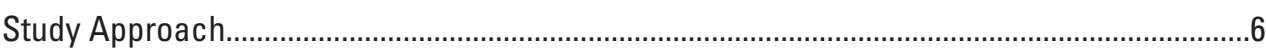

Factors with the Potential to Influence Aquifer Vulnerability and Their Variability Among Case-

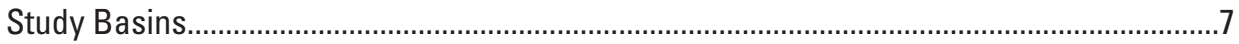

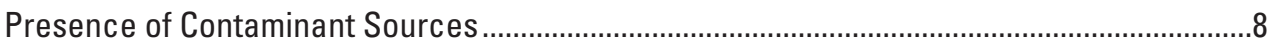

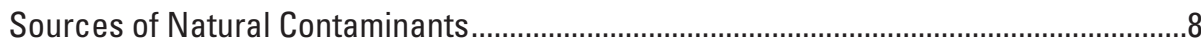

Sources of Human-Related Contaminants ................................................................11

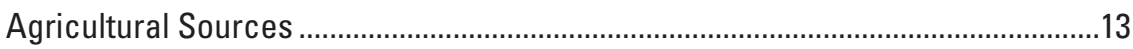

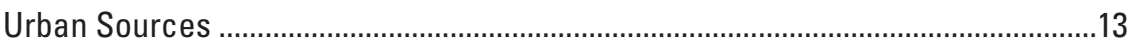

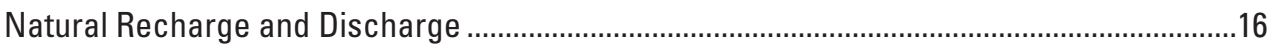

Sources and Mechanisms of Natural Recharge …………….....................................16

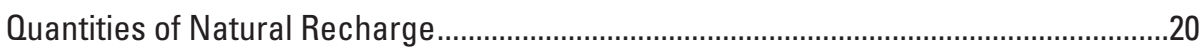

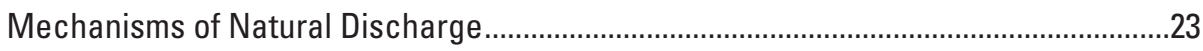

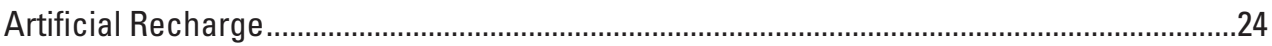

Sources and Mechanisms of Artificial Recharge .....................................................24

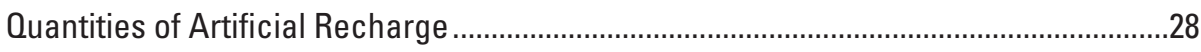

Time Scale of Development..................................................................................

Groundwater Ages and Residence Times .................................................................

Human Alterations to Groundwater Movement and Discharge ............................................36

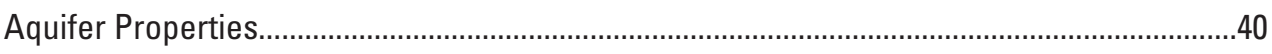

Synthesis of Contaminant Occurrence and Major Factors Affecting Aquifer Vulnerability in

Case-Study Basins .......................................................................................................

Contaminants with Important Natural and Human Sources ..................................................54

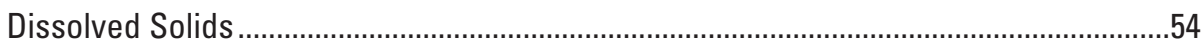

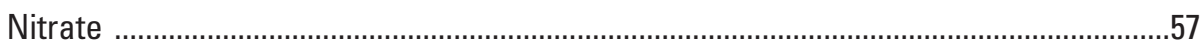

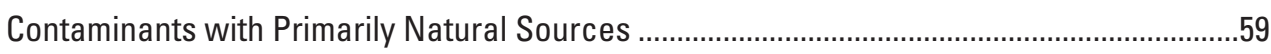

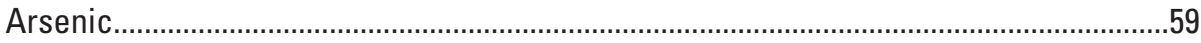

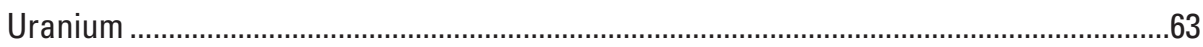

Contaminants with Primarily Human Sources .....................................................................64

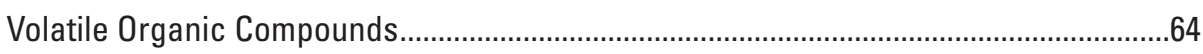

Pesticide Compounds ................................................................................................73

Conceptual Models of Important Factors Affecting Vulnerability of Southwestern Basin-Fill

Aquifers with Respect to Selected Contaminants ...............................................................74

Contaminants with Important Natural and Human Sources ....................................................76

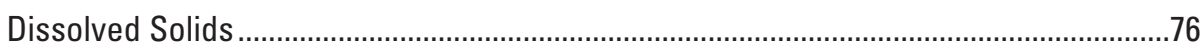

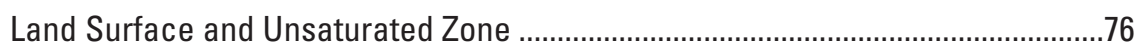

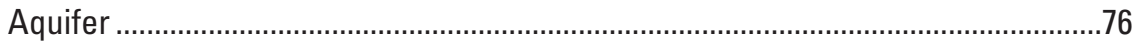




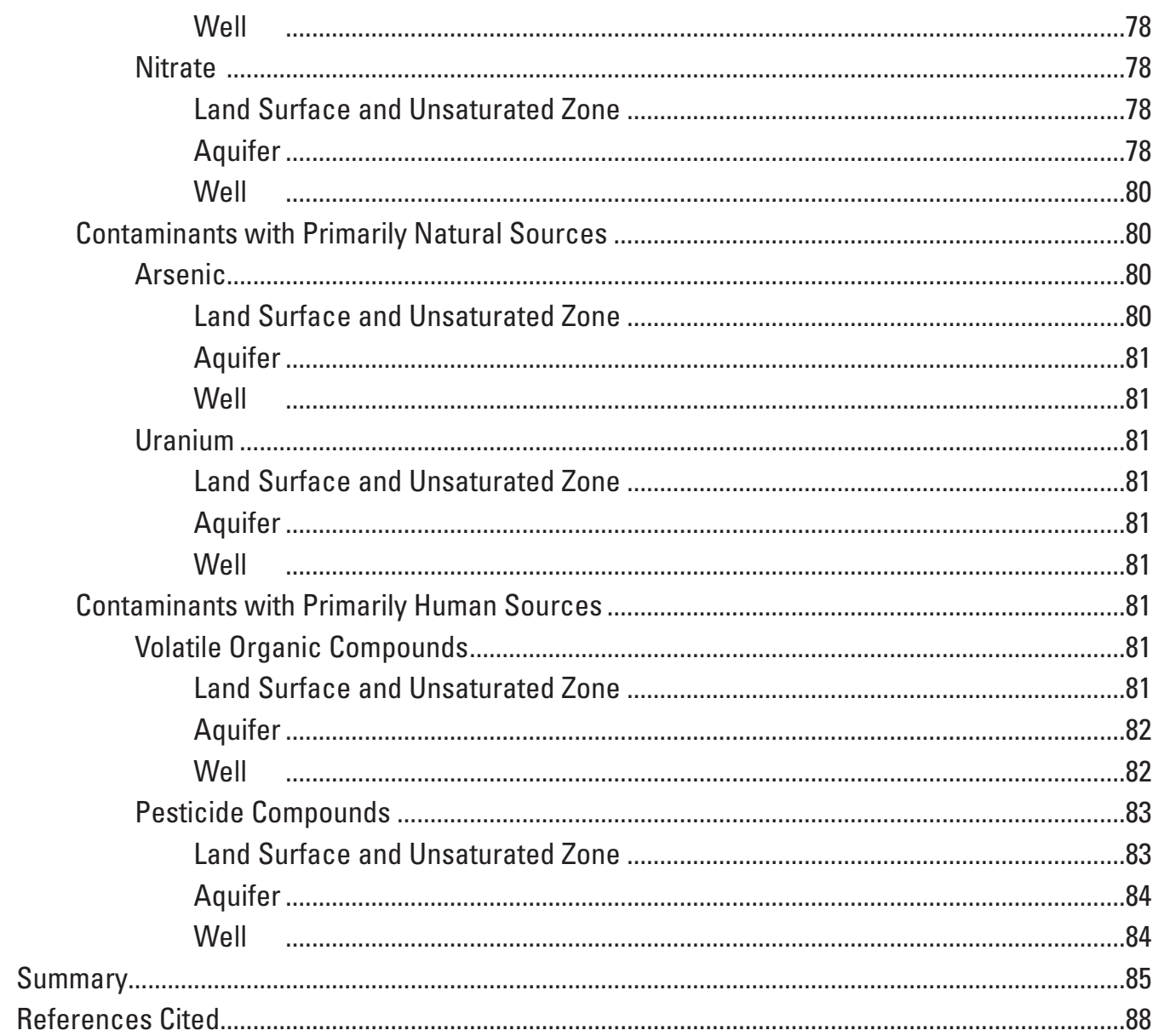

\section{Figures}

1 Map showing principal aquifers and locations of 15 basins previously studied by the National Water Quality Assessment Program in the Southwest Principal Aquifers study area 3

2 Map of generalized geology across the Southwest Principal Aquifers study area ........9

3 Pie diagrams showing categorization of generalized geology surrounding the 15 case-study basins in the Southwest Principal Aquifers study area...........................12

4 Map showing land use in the Southwest Principal Aquifers study area ......................14

5 Graph showing categorization of land use in the 15 case-study basins in the Southwest Principal Aquifers study area

6 Graph showing irrigated acreage in the 15 case-study basins in the Southwest Principal Aquifers study area.

7 Graphs showing $A$, total population and population density and $B$, percent of population on septic systems in the 15 case-study basins in the Southwest Principal Aquifers study area.

8 Generalized block diagrams for the Alamosa Basin of the San Luis Valley, Colorado, showing the basin-fill deposits and components of the groundwater system under $A$, predevelopment and $B$, modern conditions.

9 Pie diagrams showing categorization of recharge and discharge mechanisms for the 15 case-study basins in the Southwest Principal Aquifers study area under predevelopment and modern conditions 
10 Graph showing normalized quantities of recharge to the 15 case-study basins in the Southwest Principal Aquifers study area .....

11 Map showing values of the aridity index across the Southwest Principal Aquifers study area

12 Graph showing relation between land use and recharge for predevelopment and modern conditions in the 15 case-study basins in the Southwest Principal

Aquifers study area

13 Graph showing estimated quantities of groundwater pumping from case-study basins in the Southwest Principal Aquifers study area under modern conditions........37

14 Graph showing relation between increase in recharge and increase in discharge between predevelopment and modern conditions for the 15 case-study basins in the Southwest Principal Aquifers study area.

15 Generalized diagram of the potential influence of deep wells on vertical groundwater flow in an alluvial basin

16 Graphs showing a comparison of selected categories of generalized geology surrounding the 15 case-study basins in the Southwest Principal Aquifers study area for basins where interaction with rocks or sediments prior to recharge is and is not a primary source of $A$, dissolved solids, $B$, arsenic, or $C$, uranium to groundwater

17 Graphs showing a comparison of the case-study basins in the Southwest Principal Aquifers study area where $A$, agricultural or $B$, urban land use was cited as a primary contributor to groundwater contamination with respect to contaminants with human sources

18 Graphs showing a comparison of the case-study basins in the Southwest Principal Aquifers study area where $A$, high rates of artificial recharge and (or) a large degree of modification of the groundwater system or $B$, hydraulicgradient change as a result of groundwater pumping was cited as affecting the distribution of selected contaminants in groundwater.

19 Diagram showing the conceptual model of major $A$, natural and $B$, human factors affecting the vulnerability of Southwestern basin-fill aquifers to contamination with dissolved solids

20 Diagram showing the conceptual model of major $A$, natural and $B$, human factors affecting the vulnerability of Southwestern basin-fill aquifers to contamination with nitrate

21 Diagram showing the conceptual model of major natural and human factors affecting the vulnerability of Southwestern basin-fill aquifers to contamination with arsenic

22 Diagram showing the conceptual model of major natural and human factors affecting the vulnerability of Southwestern basin-fill aquifers to contamination with uranium

23 Diagram showing the conceptual model of major natural and human factors affecting the vulnerability of Southwestern basin-fill aquifers to contamination with volatile organic compounds

24 Diagram showing the conceptual model of major natural and human factors affecting the vulnerability of Southwestern basin-fill aquifers to contamination with pesticide compounds 


\section{Tables}

1 Case-study alluvial basins in the Southwestern United States included in the analysis in this report

2 Factors examined for their potential influence on groundwater quality in basin-fill aquifers of the Southwestern United States

3 Common natural and (or) human-related contaminants in Southwestern basin-fill aquifers and potential sources

4 Major agricultural land cover in the 15 case-study basins in the Southwest Principal Aquifers study area

5 Summary of the recent use of imported river water, treated wastewater, and captured runoff in the 15 case-study basins in the Southwest Principal Aquifers study area

6 Estimates of groundwater age ranges by depth and of mean groundwater residence times within the 15 case-study basin aquifers in the Southwest Principal Aquifers study area

7 Summary of aquifer properties that are important to characterization of intrinsic susceptibility and vulnerability within the 15 case-study basins in the Southwest Principal Aquifers study area.

8 Redox environments and $\mathrm{pH}$ ranges observed for groundwater in the 15 casestudy basins in the Southwest Principal Aquifers study area

9 For each of the 15 case-study basins in the Southwest Principal Aquifers study area, locations where concentrations of $A$, dissolved solids, and $B$, nitrate, which have important natural and human sources, exceed specified thresholds in groundwater and associated sources and hydrogeologic controls

10 For each of the 15 case-study basins in the Southwest Principal Aquifers study area, locations where concentrations of $A$, arsenic, and $B$, uranium, which have primarily natural sources, exceed specified thresholds in groundwater and associated sources and hydrogeologic controls

11 For each of the 15 case-study basins in the Southwest Principal Aquifers study area, locations where $A$, volatile organic compounds, and $B$, pesticide compounds, which have primarily human sources, have been detected in groundwater and associated sources and hydrogeologic controls

12 Potentially important factors recommended for inclusion in assessments/ modeling of the vulerability of Southwestern alluvial basins to contamination with selected constituents 


\section{Conversion Factors}

Inch/Pound to SI

\begin{tabular}{|c|c|c|}
\hline Multiply & By & To obtain \\
\hline \multicolumn{3}{|c|}{ Length } \\
\hline inch (in.) & 2.54 & centimeter $(\mathrm{cm})$ \\
\hline foot $(\mathrm{ft})$ & 0.3048 & meter $(\mathrm{m})$ \\
\hline mile (mi) & 1.609 & kilometer $(\mathrm{km})$ \\
\hline \multicolumn{3}{|c|}{ Area } \\
\hline acre & 4,047 & square meter $\left(\mathrm{m}^{2}\right)$ \\
\hline square mile $\left(\mathrm{mi}^{2}\right)$ & 2.590 & square kilometer $\left(\mathrm{km}^{2}\right)$ \\
\hline \multicolumn{3}{|c|}{ Volume } \\
\hline acre-foot (acre-ft) & 1,233 & cubic meter $\left(\mathrm{m}^{3}\right)$ \\
\hline \multicolumn{3}{|c|}{ Flow rate } \\
\hline acre-foot per year (acre-ft/yr) & 1,233 & cubic meter per year $\left(\mathrm{m}^{3} / \mathrm{yr}\right)$ \\
\hline inch per year (in/yr) & 25.4 & millimeter per year $(\mathrm{mm} / \mathrm{yr})$ \\
\hline \multicolumn{3}{|c|}{ Radioactivity } \\
\hline picocurie per liter $(\mathrm{pCi} / \mathrm{L})$ & 0.037 & becquerel per liter $(\mathrm{Bq} / \mathrm{L})$ \\
\hline \multicolumn{3}{|c|}{ Hydraulic conductivity } \\
\hline foot per day (ft/d) & 0.3048 & meter per day $(\mathrm{m} / \mathrm{d})$ \\
\hline
\end{tabular}

Temperature in degrees Celsius $\left({ }^{\circ} \mathrm{C}\right)$ may be converted to degrees Fahrenheit $\left({ }^{\circ} \mathrm{F}\right)$ as follows:

${ }^{\circ} \mathrm{F}=\left(1.8 x^{\circ} \mathrm{C}\right)+32$

Temperature in degrees Fahrenheit $\left({ }^{\circ} \mathrm{F}\right)$ may be converted to degrees Celsius $\left({ }^{\circ} \mathrm{C}\right)$ as follows:

${ }^{\circ} \mathrm{C}=\left({ }^{\circ} \mathrm{F}-32\right) / 1.8$

Vertical coordinate information is referenced to the insert datum name (and abbreviation) here for instance, "North American Vertical Datum of 1988 (NAVD 88)."

Horizontal coordinate information is referenced to the insert datum name (and abbreviation) here for instance, "North American Datum of 1983 (NAD 83)."

Altitude, as used in this report, refers to distance above the vertical datum.

Specific conductance is given in microsiemens per centimeter at 25 degrees Celsius $(\mu \mathrm{S} / \mathrm{cm}$ at $\left.25^{\circ} \mathrm{C}\right)$.

Concentrations of chemical constituents in water are given either in milligrams per liter (mg/L) or micrograms per liter $(\mu \mathrm{g} / \mathrm{L})$. 


\title{
Effects of Natural and Human Factors on Groundwater Quality of Basin-Fill Aquifers in the Southwestern United States-Conceptual Models for Selected Contaminants
}

\author{
By Laura M. Bexfield, Susan A. Thiros, David W. Anning, Jena M. Huntington, and Tim S. McKinney
}

\section{Abstract}

As part of the U.S. Geological Survey National WaterQuality Assessment (NAWQA) Program, the Southwest Principal Aquifers (SWPA) study is building a better understanding of the factors that affect water quality in basin-fill aquifers in the Southwestern United States. The SWPA study area includes four principal aquifers of the United States: the Basin and Range basin-fill aquifers in California, Nevada, Utah, and Arizona; the Rio Grande aquifer system in New Mexico and Colorado; and the California Coastal Basin and Central Valley aquifer systems in California. Similarities in the hydrogeology, land- and water-use practices, and water-quality issues for alluvial basins within the study area allow for regional analysis through synthesis of the baseline knowledge of groundwater-quality conditions in basins previously studied by the NAWQA Program. Resulting improvements in the understanding of the sources, movement, and fate of contaminants are assisting in the development of tools used to assess aquifer susceptibility and vulnerability.

This report synthesizes previously published information about the groundwater systems and water quality of 15 information-rich basin-fill aquifers (SWPA case-study basins) into conceptual models of the primary natural and human factors commonly affecting groundwater quality with respect to selected contaminants, thereby helping to build a regional understanding of the susceptibility and vulnerability of basinfill aquifers to those contaminants. Four relatively common contaminants (dissolved solids, nitrate, arsenic, and uranium) and two contaminant classes (volatile organic compounds (VOCs) and pesticide compounds) were investigated for sources and controls affecting their occurrence and distribution above specified levels of concern in groundwater of the casestudy basins. Conceptual models of factors that are important to aquifer vulnerability with respect to those contaminants and contaminant classes were subsequently formed. The conceptual models are intended in part to provide a foundation for subsequent development of regional-scale statistical models that relate specific constituent concentrations or occurrence in groundwater to natural and human factors.
Synthesis of information available for the SWPA casestudy basins indicated the types of sources (natural and human) that are important to occurrence of the studied contaminants in groundwater. Among natural sources of contaminants, the geologic composition of rocks and (or) sediments within the alluvial basin and in adjacent recharge areas is of primary importance for dissolved solids, arsenic, and uranium. The presence of geothermal water is another important source for dissolved solids and arsenic, and flushing of natural soil-zone or subsoil accumulations is an important source for nitrate. Among human sources of contaminants, excess irrigation water infiltrating through agricultural fields is important for dissolved solids, nitrate, and pesticide compounds; infiltrating agricultural wastewater also is important for dissolved solids and nitrate. Urban sources, including point sources (such as landfills, leaky storage tanks, spills, and (or) improper disposal points in industrial, commercial, and (or) military settings), chlorinated municipal-supply water infiltrating through irrigated yards/turf areas or leaking from distribution pipes, seepage of water from sewer and septic systems, treated urban wastewater infiltrating through streams or irrigated fields, diffuse urban runoff, and (or) engineered recharge water are important for dissolved solids, nitrate, VOCs, and pesticide compounds.

Natural and human-related factors other than sources also are important to the vulnerability of Southwestern basin-fill aquifers to contamination. Among natural hydrogeologic factors, rates of evapotranspiration are important for dissolved solids and nitrate; presence/absence of confining units and (or) of upward versus downward natural hydraulic gradients are important for dissolved solids, nitrate, VOCs, and pesticide compounds; redox conditions in the aquifer are important for nitrate, VOCs, pesticide compounds, arsenic, and uranium; and $\mathrm{pH}$ values and groundwater residence times in the aquifer are important for arsenic. Among human-related factors, depth to water in areas of artificial recharge, contribution of artificial recharge to the basin budget, magnitude of pumping stresses, and well depth are all important for dissolved solids, nitrate, VOCs, and pesticide compounds; preferential groundwater flow along wellbores is another important control for VOCs and pesticides. In addition, presence of urban recharge in areas of previous agricultural activity is important for nitrate. 
The conceptual models presented in this report are intended to provide a general understanding of major factors that should be considered in broad-scale characterization of aquifer vulnerability in alluvial basins of the Southwestern United States and to help guide future efforts at statistical modeling of contaminant occurrence. The conceptual models should not be viewed as representing all potential factors important to the vulnerability of all Southwestern basin-fill aquifers to any class of contaminant. Future advancements in the knowledge of factors affecting aquifer vulnerability within individual Southwestern basin-fill aquifers will allow for continuing improvement of the understanding of factors that also are important on a regional scale.

\section{Introduction}

The National Water-Quality Assessment (NAWQA) Program of the U.S. Geological Survey is conducting a regional analysis of water quality in the principal aquifer systems in the southwestern United States (Southwest). The Southwest Principal Aquifers (SWPA) study is building a better understanding of the susceptibility and vulnerability of basin-fill aquifers in the region to groundwater contamination by synthesizing the baseline knowledge of groundwater-quality conditions in 15 basins previously studied by the NAWQA Program (fig. 1). The improved understanding of aquifer susceptibility and vulnerability to contamination is assisting in the development of tools that water managers can use to assess and protect the quality of groundwater resources. The NAWQA Program is performing similar regional investigations for other principal aquifers across the country (Lapham and others, 2005).

\section{Background on the Southwest Principal Aquifers Study}

Basin-fill aquifers underlie about 49 percent of the 409,000-mi² SWPA study area (McKinney and Anning, 2009) and are the primary groundwater supply for cities and agricultural communities in the region. In several areas, these aquifers provide base flow to streams that support important aquatic and riparian habitats. When aggregated across the study area, the basin-fill aquifers comprise four of the principal aquifers of the United States: the Basin and Range basin-fill aquifers in California, Nevada, Utah, and Arizona; the Rio Grande aquifer system in New Mexico and Colorado; and the California Coastal Basin aquifers and the Central Valley aquifer system in California (fig. 1; U.S. Geological Survey, 2003a).

About 46.6 million people live in the SWPA study area (Oak Ridge National Laboratory, 2005), mostly in urban metropolitan areas but also in rural agricultural communities that tend about 14.4 million acres $\left(22,500 \mathrm{mi}^{2}\right)$ of cropland (U.S. Geological Survey, 2003b). Other rural areas contain small communities with mining, retirement, and (or) tourism/ recreational-based economies. Because of the generally limited availability of surface-water supplies in the arid to semiarid climate, cultural and economic activities in the region are particularly dependent on good-quality groundwater supplies. In the year 2000, about 33.7 million acre-ft of surface water was diverted from streams, and about 23.0 million acre- $\mathrm{ft}$ of groundwater was withdrawn from aquifers in the SWPA study area (U.S. Geological Survey, 2008). Irrigation and publicsupply withdrawals from basin-fill aquifers in the study area for 2000 were about 18.0 million acre-ft and 4.1 million acre$\mathrm{ft}$, respectively, and together account for about one quarter of the total withdrawals from all aquifers in the United States (Maupin and Barber, 2005). Although irrigation and public supply are the primary uses of basin-fill aquifer withdrawals in the study area, water use varies locally by basin and withdrawals for industrial, mining, and electric power generation also are substantial in some areas.

\section{Basin-Fill Aquifers}

Basin-fill aquifers primarily consist of sand and gravel deposits that partly fill structurally formed depressions and are bounded by consolidated-rock mountains. In some areas, fine-grained deposits of silt and clay are interbedded with the porous sand and gravel deposits, forming confining units that retard vertical movement of groundwater. Most basins contain thick sequences of basin-fill deposits, and the sediments generally become increasingly more compacted and less permeable with depth. Many basins are drained by a stream that flows (sometimes intermittently) through a gap in the consolidated rock, although some basins are closed and groundwater and surface water are removed naturally only by evapotranspiration. High-energy mountain streams have formed alluvial fans with coarse-grained sediment deposited along the mountain fronts. The unsaturated zones below alluvial-fan surfaces usually are several hundred feet thick and are underlain by an unconfined aquifer. Steep alluvial fans transition to a relatively flat valley floor where lacustrine and fluvial depositional environments often have created layers of fine-grained sediment interbedded with more permeable layers of sand and gravel. This usually results in confined conditions and upward vertical gradients in discharge areas in the central part of the basin. Somewhat continuous clay layers occur within about $100 \mathrm{ft}$ of the land surface in some basins, forming a shallow aquifer system above the uppermost clay layer that can be perched or that can contribute to or receive water from the underlying confined aquifer.

The primary sources of natural recharge to the deeper parts of the basin-fill aquifers are precipitation on the surrounding mountains and infiltration from streams. Runoff from the surrounding mountains seeps into the coarser-grained streamchannel and alluvial-fan deposits near the basin margins. Precipitation also can infiltrate the consolidated mountain rock where it is fractured or porous and can move into the basin-fill deposits. Low precipitation rates, combined with high evaporation rates, result in a relatively small contribution of groundwater recharge from precipitation falling on the basin floor (generally less than 5 percent of annual precipitation). Much 


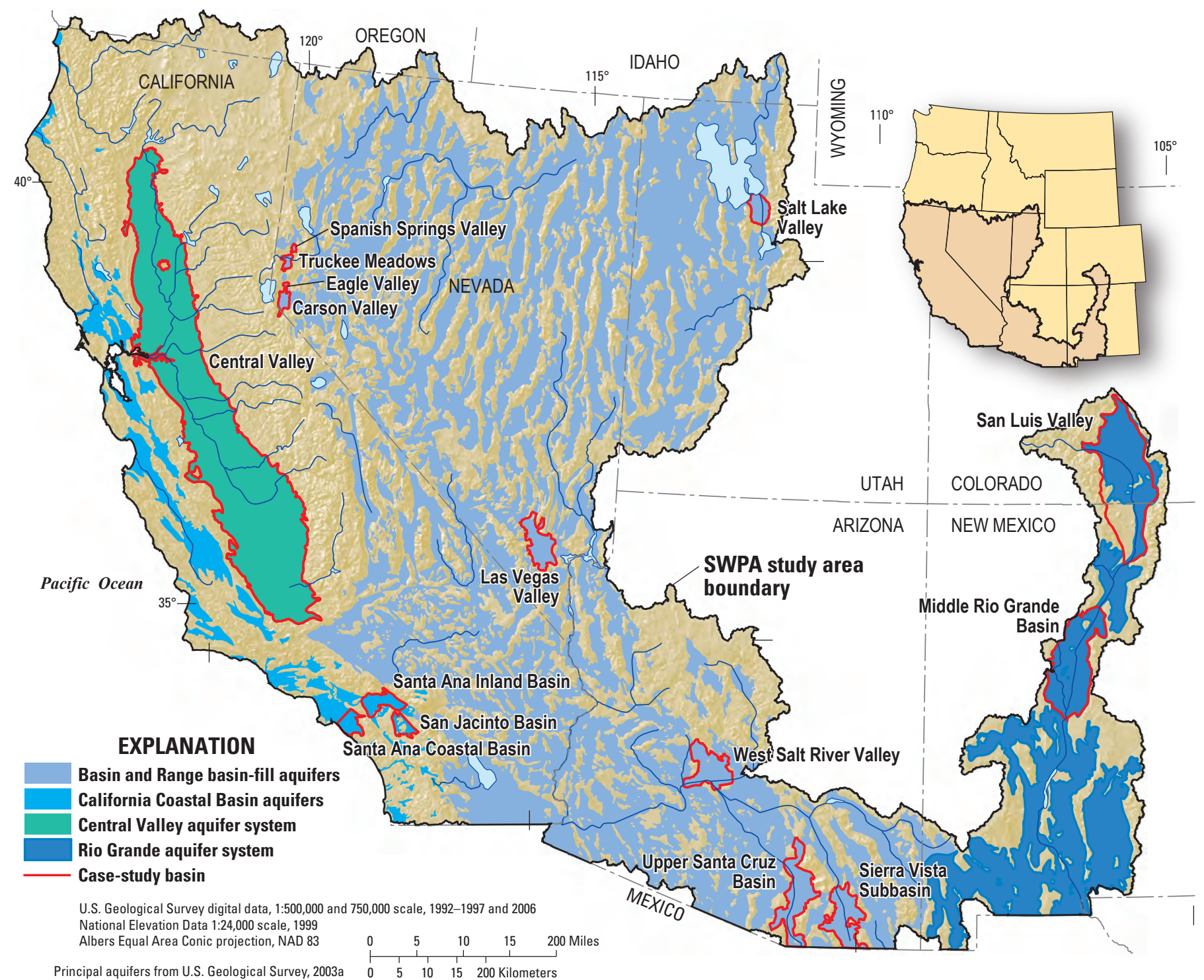

Figure 1. Principal aquifers and locations of 15 basins previously studied by the National Water Quality Assessment Program in the Southwest Principal Aquifers study area.

of that recharge is focused as infiltration through ephemeral stream channels. Some recharge occurs as subsurface inflow of groundwater from adjacent basins.

Before human development of water resources began in the alluvial basins, groundwater recharge and discharge were in equilibrium. Groundwater discharge typically was by evapotranspiration of shallow groundwater in wetlands or playas (in closed basins) and by discharge to streams flowing through the basins. The cities of Las Vegas, Nevada; Tucson, Arizona; and San Bernardino, California, owe their locations to the availability of groundwater that used to discharge to streams or springs throughout the year. In some basins, natural discharge occurs as subsurface outflow to adjacent basins; however, in other basins, faulting and constrictions in the bedrock that surrounds the aquifer restrict groundwater outflow (Anning and Konieczki, 2005).

\section{Changes to the Basin-Fill Aquifers}

With water development, some basin-fill aquifers have changed considerably as a result of an increase in the amount and number of mechanisms for recharge and discharge. Artificial recharge sources include seepage of irrigation water applied to crops and lawns; seepage from canals, water distribution pipes, sewer pipes, and septic systems; infiltration of stormwater runoff from retention basins, recharge basins, and dry wells; seepage of treated wastewater through streambeds or irrigated fields; and infiltration in recharge ponds or well-injection of surface water or imported water. Recharge from these artificial sources introduces water to parts of the groundwater system that previously received little or no recharge from the land surface. For some basins, the increase in recharge and redistribution of water to areas that previously did not receive recharge have resulted in increased saturated 
thicknesses, increased flow velocities, and (or) changes in flow directions.

For many basins, withdrawal from pumping wells has become the primary source of groundwater discharge and is greater than groundwater recharge. In some basins, the imbalance between recharge and discharge has led to large decreases in groundwater storage and (or) decreases in groundwater discharge to streams and evapotranspiration. Water-level declines and changes in flow directions and magnitudes occur where groundwater withdrawals are large. The increased rates of recharge and discharge associated with water development have increased flow through many basin-fill aquifers, especially from the land surface to the shallower parts of the aquifer. However, groundwater withdrawals from the deep wells typically used for public supply also have resulted in enhanced movement of groundwater from shallower to deeper parts of the basin-fill aquifers. Water development, therefore, typically results in aquifers being more susceptible to water-quality degradation by human activities at the land surface and more vulnerable to contaminants where sources are present.

The ease with which water enters and moves through an aquifer is described as its intrinsic susceptibility (Focazio and others, 2002). Aquifer susceptibility depends on the aquifer properties and other characteristics such as recharge rate, the presence or absence of an overlying confining unit, groundwater traveltime, thickness and characteristics of the unsaturated zone, and pumping. The vulnerability of groundwater to contamination is the probability for contaminants to reach a specified part of an aquifer after being introduced, usually at the land surface. Vulnerability depends on the properties of the groundwater system (susceptibility), the proximity of contaminant sources, and the chemical characteristics of the contaminant. Long groundwater residence times and slow rates of contaminant degradation in basin-fill aquifers of the SWPA study area can make the process of contaminating groundwater virtually irreversible and treatment prohibitively expensive or otherwise impractical. Therefore, it is imperative to understand the primary natural and human factors associated with the susceptibility and vulnerability of these aquifers to contamination, which allows water managers to plan for their optimal protection and utilization.

\section{Regional Analysis}

Similarities in hydrogeology, land- and water-use practices, and water-quality issues among the basin-fill aquifers of the SWPA study area allow for regional analysis. Regional analysis begins by determining the primary influential factors that commonly affect water quality and the associated susceptibility and vulnerability of basin-fill aquifers to contamination, on the basis of data and information from a subset of information-rich basin-fill aquifers in the study area. Variations in the presence and magnitude of these influential factors across the basins allow for determination of the effects of each factor and for development of conceptual and mathematical susceptibility and vulnerability models of these effects. The models formed for these areas then can be extended to areas lacking groundwater-quality data and interpretive studies.

During its first data-collection and analysis phase from 1991 to 2001, the NAWQA Program sampled wells and established baseline water-quality conditions for basin-fill aquifers in 15 basins across the study area (SWPA case-study basins) (fig. 1 and table 1). Groundwater quality also was investigated for relations to natural and human factors on the basis of a wide suite of constituents including major ions, nutrients, trace elements, pesticides, and volatile organic compounds (VOCs). These studies developed detailed knowledge of local conditions and factors affecting groundwater quality for each basin individually, and the SWPA study is developing a regional understanding by synthesizing results from the 15 basin studies into a common set of factors and themes found to affect water quality in basin-fill aquifers across the Southwest. The synthesis consists of three major components:

1. A review that summarizes current knowledge about the groundwater systems and the status of, trends in, and influential factors affecting groundwater quality of basin-fill aquifers in the 15 individual basins previously studied by NAWQA (Thiros and others, 2010),

2. Development of conceptual models of the primary natural and human factors commonly affecting groundwater quality with respect to selected contaminants, thereby helping to build a regional understanding of the susceptibility and vulnerability of basin-fill aquifers to those contaminants (this report), and

3. Development of statistical models that relate specific constituent concentrations or occurrence in groundwater to

Table 1. Case-study alluvial basins in the Southwestern United States included in the analysis in this report.

\begin{tabular}{ll}
\hline \multicolumn{1}{c}{ Case-study alluvial basin } & \multicolumn{1}{c}{ Principal aquifer system } \\
\hline Salt Lake Valley, Utah & Basin and Range Basin-Fill Aquifers \\
\hline Truckee Meadows, Nevada & Basin and Range Basin-Fill Aquifers \\
\hline Eagle Valley, Nevada & Basin and Range Basin-Fill Aquifers \\
\hline Carson Valley, Nevada & Basin and Range Basin-Fill Aquifers \\
\hline Spanish Springs Valley, Nevada & Basin and Range Basin-Fill Aquifers \\
\hline Las Vegas Valley, Nevada & Basin and Range Basin-Fill Aquifers \\
\hline West Salt River Valley, Arizona & Basin and Range Basin-Fill Aquifers \\
\hline Upper Santa Cruz Basin, Arizona & Basin and Range Basin-Fill Aquifers \\
\hline $\begin{array}{l}\text { Sierra Vista Subbasin (of the Upper } \\
\text { San Pedro Basin), Arizona }\end{array}$ & Basin and Range Basin-Fill Aquifers \\
\hline $\begin{array}{l}\text { San Luis Valley, Colorado and New } \\
\text { Mexico }\end{array}$ & Rio Grande Aquifer System \\
\hline $\begin{array}{l}\text { Middle Rio Grande Basin, New } \\
\text { Mexico }\end{array}$ & Rio Grande Aquifer System \\
\hline $\begin{array}{l}\text { San Jacinto Basin (of the Santa Ana } \\
\text { Basin), California }\end{array}$ & California Coastal Basin Aquifers \\
\hline Santa Ana Inland Basin, California & California Coastal Basin Aquifers \\
\hline Santa Ana Coastal Basin, California & California Coastal Basin Aquifers \\
Central Valley, California & Central Valley Aquifer System \\
\hline
\end{tabular}


natural and human factors linked to the susceptibility and vulnerability of basin-fill aquifers to contamination (ongoing investigation).

Resource managers and scientists will be able to use the results of the SWPA regional water-quality studies in assessing the susceptibility and vulnerability of groundwater to contamination in both thoroughly and sparsely studied basins across the SWPA study area. By identifying natural and human factors and processes affecting the occurrence and transport of selected contaminants, the assessments will allow managers and scientists to apply findings to broader classes of contaminants. Regional-scale models and other decision-support tools that integrate aquifer characteristics, land use, and waterquality monitoring data will help water managers to estimate water-quality conditions in unmonitored areas, assess the susceptibility and vulnerability of groundwater under different future basin-development scenarios, and develop cost-effective groundwater-monitoring programs.

\section{Purpose and Scope}

This report documents conceptual models of the primary natural and human factors commonly affecting selected contaminants in groundwater of basin-fill aquifers in the SWPA study area. Specifically, this report includes descriptions of:

1. Natural and human factors that have the potential to influence groundwater quality across Southwestern basin-fill aquifers and values of those factors represented among the 15 SWPA case-study basins previously studied by NAWQA and summarized in the companion report "Conceptual understanding and groundwater quality of selected basin-fill aquifers in the Southwestern United States" (Thiros and others, 2010).

2. A synthesis of information about and commonalities among natural and human factors documented to influence aquifer susceptibility and vulnerability with respect to selected contaminants in the 15 SWPA case-study basins.

3. Conceptual models of the most important natural and human factors affecting the susceptibility and vulnerability of Southwestern basin-fill aquifers to selected contaminants, as indicated by the synthesis of available information for the 15 SWPA case-study basins.

This report builds on individual studies of factors that affect water quality, as summarized in Thiros and others (2010), by synthesizing and simplifying findings into generalized conceptual models for selected contaminants. The conceptual models are intended in part to provide a foundation for subsequent development of regional-scale statistical models that relate specific groundwater-quality constituent concentrations or occurrence to natural and human factors linked to the susceptibility and vulnerability of basin-fill aquifers to contamination. Several natural and human factors that potentially affect groundwater quality are represented by datasets compiled by McKinney and Anning (2009) as part of the SWPA study.

\section{Previous Regional Investigations of Southwestern Basin-Fill Aquifers}

Multiple studies have been published on various aspects of the groundwater systems in individual basin-fill aquifers around the Southwest, but only a few studies have attempted to provide a regional picture of processes affecting groundwater flow and water quality. The publications that are available for individual Southwestern basins are too numerous to address here but are listed in Thiros and others (2010) for the 15 basins described in detail in that SWPA study report. Each basin description in Thiros and others (2010) discusses the current knowledge of groundwater quality in that basin and provides information about various influential factors believed to affect the groundwater quality, including population, land use, water use, recharge and discharge mechanisms, and flow directions. Data for several of the natural and human factors presented in Thiros and others (2010), particularly those factors relating to physiography, population, land use, and water use, are compiled in McKinney and Anning (2009) for all 425 basins within the SWPA study area.

Previous SWPA regional investigations have documented and modeled natural and human effects on selected constituents in basin-fill aquifers across the SWPA study area. Paul and others (2007) used NAWQA data collected for 1993-2004 to investigate water quality of the shallow, upper parts of several basin-fill aquifers in the SWPA study area and found them vulnerable to high nitrate concentrations (above 10 $\mathrm{mg} / \mathrm{L}$ ) where fertilizer is used, land is irrigated using sprinkler methods, and oxidizing conditions are present in the groundwater. Similarly, Paul and others (2007) found that occurrence of selected pesticides is affected by oxidation/reduction conditions, soil permeability, groundwater temperature, and depth to the screened interval of the well. Occurrence of selected VOCs was found to be affected by oxidation/reduction conditions, $\mathrm{pH}$, and industrial land use. Anning and others (2007) investigated salinity in many basin-fill aquifers of the SWPA study area and found that dissolved-solids concentrations typically increase along flow paths as a result of geochemical reactions with the aquifer matrix, dissolution of disseminated salts and massive evaporite deposits, and evapotranspiration of shallow groundwater by natural vegetation or by agricultural crops. Mixing with inflows of groundwater, stream seepage, or irrigation seepage with higher concentrations also was shown to cause increases in dissolved-solids concentrations along flow paths.

Other USGS studies with large areal extents in the Southwest include those of the Regional Aquifer-System Analysis (RASA) and the Regional Groundwater Availability Programs. Many of these studies used computer models to develop estimates of water availability at the time of the study and into the future. The National Ground-Water Atlas was compiled using RASA findings as a general source of information on groundwater resources (Miller, 1999) and includes the principal aquifer systems described in this report. 
Other publications also have investigated components of the groundwater budgets for multiple Southwestern basin-fill aquifers. Hogan and others (2004) and Stonestrom and others (2007) focused particularly on arid and semiarid recharge mechanisms and quantities. Anning and Konieczki (2005) classified Southwestern basins on the basis of hydrogeologic characteristics, whereas Reilly and others (2008) investigated groundwater availability. Paschke (2007) described regional groundwater budgets, general groundwater-quality characteristics, and areas modeled to contribute recharge to public-supply wells in four basins within the SWPA study area.

\section{Study Approach}

Three major tasks were required to construct conceptual models of natural and human factors commonly affecting selected contaminants in groundwater of basin-fill aquifers within the SWPA study area. The first was compilation of information about factors that could potentially affect groundwater quality and the range in values for those factors represented among the 15 SWPA case-study basins. The second was synthesis of information on the occurrence of selected contaminants and on major factors documented or otherwise likely to affect aquifer vulnerability with respect to those contaminants in each of the case-study basins. Third was incorporation of the synthesized information into conceptual models of the most important sources and hydrogeologic factors that commonly affect those contaminants between the land surface and wells, largely determining the overall susceptibility and vulnerability of SWPA basin-fill aquifers to those contaminants.

Compilation of information about factors that could potentially affect groundwater quality in the SWPA study area included natural and human sources and hydrogeologic factors thought to influence transport of contaminants to groundwater and fate of contaminants within the basin-fill aquifers of the 15 case-study basins described in Thiros and others (2010). Factors that were examined for their potential influence on contaminants in groundwater are listed in table 2; factors related to hydrogeology, land use, water use, natural and artificial recharge, groundwater traveltime, and general chemical characteristics of water in the aquifer are included. Tables and diagrams of specific measures of these factors - and combinations of factors - were created to examine the range of values present among case-study basins. In order to generate defensible conceptual models about aquifer vulnerability constructed using information from these case-study basins, the basins needed to represent a wide range of conditions with respect to factors listed in table 2.
Information on the occurrence of selected contaminants in the case-study basins and on major factors believed to affect aquifer vulnerability with respect to those contaminants was synthesized in summary tables (organized by individual contaminant or contaminant class) and on diagrams. The areal and vertical distribution of an individual contaminant or contaminant class within a basin was described with respect to a specified concentration threshold or in terms of presence/ absence, as appropriate. Selection of important sources and hydrogeologic factors to be listed in the tables for an individual basin was based on previously published studies of groundwater quality in the basin combined with knowledge of the overall hydrogeologic characteristics of the basin. The summary tables were designed to use consistent qualitative descriptions of potential sources and hydrogeologic factors that were general enough for application to any Southwestern basin. For individual contaminants or contaminant classes, table entries were compared across basins to allow determination of the contaminants that were most commonly of concern across broad spatial scales and of the sources and hydrogeologic factors that were most commonly documented to affect contaminant occurrence. Where applicable, graphs and statistical tests were used to compare relevant data (such as percent agricultural land) between basins where a certain source/factor (such as irrigation water infiltrating from agricultural fields) was cited as a primary contributor to contamination and basins where it was not cited. For statistical testing, the exact form of the rank-sum test (Helsel and Hirsch, 1995) was used to determine the probability that the central value of two groups was significantly different.

After information on factors most commonly of importance to contaminant occurrence among the case-study basins had been synthesized, that information was incorporated into contaminant-specific conceptual models of the most important sources and hydrogeologic factors affecting aquifer vulnerability. The conceptual models were designed to illustrate the effects of those sources and hydrogeologic factors on the transport of contaminants to groundwater and the fate of contaminants within Southwestern basin-fill aquifers - that is, to illustrate processes occurring everywhere along a flow path from the land surface to wells. The conceptual models also were designed to emphasize factors that were cited as being of importance in at least 20 percent of case-study basins, to keep the number of major factors manageable and prevent the models from becoming too complex for practical application. The models incorporated the same descriptions of sources and hydrogeologic factors used in the second step of the model approach, so that the descriptions would be general enough to apply to even sparsely-studied basins (as opposed to the information-rich case-study basins used in model development). 
Table 2. Factors examined for their potential influence on groundwater quality in basin-fill aquifers of the Southwestern United States.

\begin{tabular}{l} 
Natural factors \\
\hline Presence of natural contaminant sources \\
Lithology of basin-fill deposits and surrounding bedrock \\
Presence of faults as preferred pathways
\end{tabular}

Aquifer properties
Hydraulic-conductivity distribution
Presence of extensive clay layers
Unsaturated-zone thickness
Natural vertical hydraulic gradients
Groundwater chemistry (redox and $\mathrm{pH}$ )

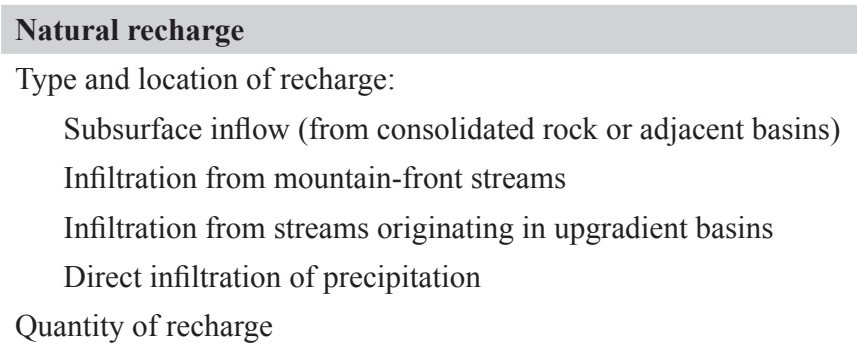

\section{Natural discharge}

Type and location of discharge:

Evapotranspiration

Subsurface outflow

Discharge to streams

\begin{tabular}{l} 
Human factors \\
\hline Presence of human contaminant sources \\
Agricultural land use \\
Urban land use
\end{tabular}

\section{Artificial recharge}

Source of artificial recharge water (for example, native surface water or treated wastewater)

Type and location of recharge:

Infiltration from irrigation canals

Infiltration through irrigated fields/lawns

Infiltration from stream channels (used for artificial recharge or to transport imported water)

Infiltration from spreading basins

Injection wells

Dry wells

Septic fields

Quantity of recharge

\section{Other}

Groundwater ages/traveltimes

Basin flow-system type (open or closed)

Chemical/physical properties of natural contaminants

\section{Factors with the Potential to Influence Aquifer Vulnerability and Their Variability Among Case-Study Basins}

A variety of natural and human factors acting on regional and (or) local scales have the potential to influence groundwater quality in basin-fill aquifers in the SWPA study area. The descriptions of the 15 SWPA case-study basins presented in Thiros and others (2010) include general overviews of groundwater quality and discussions of the factors thought to affect transport of contaminants to groundwater and fate of contaminants within the aquifers of those basins. In this section, the means by which those factors would be likely to affect groundwater quality are detailed, and examples of the documented influence of selected factors are provided using

\section{Alterations to groundwater movement and discharge \\ Gradient change resulting from artificial recharge \\ Location and quantity of groundwater withdrawal \\ Discharge to groundwater drains \\ Wells acting as short-circuits for groundwater flow \\ Gradient change resulting from new discharge mechanisms}

\section{Other}

Time scale of development

Altered groundwater ages/traveltimes

Chemical/physical properties of human contaminants information presented in Thiros and others (2010), unless other citations are specified. Also, for each factor, the range of values present among case-study basins is presented and discussed using statistics documented in McKinney and Anning (2009), unless other citations are specified.

The discussion of factors below is divided into sections that address the sources of various contaminants, the means by which those contaminants can be transported to an aquifer, and the possible fate of those contaminants along a flow path within an aquifer. The section on sources addresses the issue of how natural and (or) manmade contaminants can become available for potential transport to the aquifer. The sections on recharge and discharge processes address the natural and human-related driving forces (recharge) that can result in transport of a contaminant to an aquifer, and the mechanisms of water removal that might or might not also 
allow for associated contaminants to be removed from the aquifer (discharge). Natural recharge processes are discussed separately from human-related (or artificial) recharge sources because of the very different recharge distributions, quantities, and mechanisms that have been introduced to Southwestern basin-fill aquifers through human activities. The section on human alterations to groundwater movement and discharge addresses how human activities have altered flow paths and flow rates within aquifers, resulting in changes with respect to the particular parts of an aquifer that are most vulnerable to contamination. Finally, the section on aquifer properties addresses natural characteristics that can affect how easily water is transported to and through the aquifer and factors that can affect the fate and transport of particular contaminants (such as how readily those contaminants might become immobilized or degraded).

\section{Presence of Contaminant Sources}

Constituents that are considered groundwater contaminants include both manmade compounds (such as chlorinated solvents and pesticides) and naturally occurring constituents (such as dissolved solids and arsenic) that can prohibit the use of water for drinking or other purposes if they are present at concentrations exceeding certain thresholds. In order for contaminants to impact the quality of groundwater in an individual aquifer, they must be present in an area where they can be transported to the aquifer, either by natural mechanisms or through human activities. Some common constituents considered to be natural and (or) human-related contaminants, along with potential sources of those contaminants, are listed in table 3. The presence of sources of natural and human-related contaminants can differ widely among Southwestern basins, depending on such factors as geology and land use.

\section{Sources of Natural Contaminants}

Probably the most important control on the availability of natural contaminants to the groundwater of Southwestern basin-fill aquifers is geology. Some geologic materials weather more easily than others, which can result in a larger contribution of dissolved constituents to groundwater. The individual constituents contributed to water during weathering vary according to the composition of the geologic material that is being broken down. Also, some geologic materials have large quantities of particular constituents sorbed to their surfaces; even in the absence of weathering, those constituents can be released to groundwater under geochemical conditions that are conducive to desorption.

Table 3. Common natural and (or) human-related contaminants in Southwestern basin-fill aquifers and potential sources.

\begin{tabular}{|c|c|}
\hline \multicolumn{2}{|c|}{ Natural contaminants and sources } \\
\hline Contaminant & Potential sources \\
\hline Arsenic & $\begin{array}{l}\text { Desorption from aquifer materials } \\
\text { or surrounding bedrock; mineral } \\
\text { dissolution; movement of old, } \\
\text { mineralized water from depth } \\
\text { (possibly along faults) }\end{array}$ \\
\hline Dissolved solids & $\begin{array}{l}\text { Evapotranspiration in recharge } \\
\text { or discharge areas; dissolution } \\
\text { of minerals in the aquifer } \\
\text { or surrounding bedrock; } \\
\text { recharge though soil zones } \\
\text { where dissolved solids } \\
\text { have concentrated through } \\
\text { evapotranspiration; movement } \\
\text { of old, mineralized water from } \\
\text { depth (possibly along faults) }\end{array}$ \\
\hline Fluoride & $\begin{array}{l}\text { Mineral dissolution; weathering of } \\
\text { surrounding bedrock }\end{array}$ \\
\hline Nitrate & $\begin{array}{l}\text { Recharge through soil zones where } \\
\text { nitrate has concentrated through } \\
\text { evapotranspiration or through } \\
\text { fixation by natural vegetation; } \\
\text { mineral dissolution }\end{array}$ \\
\hline Radon & $\begin{array}{l}\text { Radioactive decay as part of } \\
\text { the decay series of naturally } \\
\text { occurring uranium }\end{array}$ \\
\hline Uranium & $\begin{array}{l}\text { Weathering of surrounding bedrock } \\
\text { (particularly granitic rocks); de- } \\
\text { sorption from aquifer materials } \\
\text { or surrounding bedrock }\end{array}$ \\
\hline
\end{tabular}

\begin{tabular}{|c|c|c|}
\hline \multicolumn{3}{|c|}{ Human-related contaminants and sources } \\
\hline Contaminant type & Example compound(s) & Potential sources \\
\hline Dissolved solids & Not applicable & $\begin{array}{l}\text { Agricultural irrigation return flow; } \\
\text { agricultural wastewater; urban irrigation } \\
\text { water and (or) runoff; septic-tank effluent; } \\
\text { treated urban wastewater; engineered } \\
\text { recharge; artificial recharge through } \\
\text { soil zones where dissolved solids have } \\
\text { concentrated through evapotranspiration }\end{array}$ \\
\hline $\begin{array}{l}\text { Gasoline hydrocarbons, } \\
\text { oxygenates }\end{array}$ & $\begin{array}{l}\text { Benzene; methyl tert-butyl } \\
\text { ether }\end{array}$ & Leaky storage tanks; gasoline spills \\
\hline Nitrate & Not applicable & $\begin{array}{l}\text { Agricultural irrigation return flow; } \\
\text { agricultural wastewater; urban irrigation } \\
\text { water and (or) runoff; septic-tank } \\
\text { effluent; sewer-line leakage; treated urban } \\
\text { wastewater; artificial recharge through } \\
\text { soil zones where nitrate has concentrated } \\
\text { through evapotranspiration }\end{array}$ \\
\hline Pesticides (agricultural) & $\begin{array}{l}\text { Atrazine, diuron, } \\
\text { metolachlor, simazine }\end{array}$ & $\begin{array}{l}\text { Agricultural irrigation return flow; } \\
\text { accidental spills }\end{array}$ \\
\hline Pesticides (urban) & Prometon & Urban irrigation water and (or) runoff \\
\hline Solvents & $\begin{array}{l}\text { Tetrachloroethylene, } \\
\text { trichloroethylene }\end{array}$ & Leaky storage tanks; solvent spills \\
\hline Trihalomethanes & Chloroform & $\begin{array}{l}\text { Water-distribution line leakage; sewer-line } \\
\text { leakage; infiltration of chlorinated urban } \\
\text { irrigation water and (or) runoff }\end{array}$ \\
\hline
\end{tabular}


Knowledge of the type of bedrock surrounding an individual basin is particularly useful in determining which natural contaminants are most likely to be present in groundwater of that basin. The type of surrounding bedrock is important for several reasons: some groundwater in the aquifer of the basin might have recharged directly through that bedrock, some surface water that recharges the aquifer might have flowed along that bedrock, and that bedrock is commonly the source rock for alluvium that composes the basin-fill aquifer. An example of the importance of bedrock type to the availability of potential groundwater contaminants was illustrated by modeling the sources and accumulation of dissolved solids in the Southwest using a mass-balance analysis of the contributions and losses of dissolved solids for river systems (Anning and others, 2007). Model results indicated that the delivery rates of dissolved solids to river reaches varies significantly by rock type, given all other conditions are equal, with crystalline rocks contributing 6.52 (ton $/ \mathrm{yr}) / \mathrm{mi}^{2}$, volcanic rocks contributing 10.66 to 16.20 (ton $/ \mathrm{yr}) / \mathrm{mi}^{2}$, and most sedimentary rock types of Precambrian through Tertiary age (including carbonate rocks) contributing at least 29.28 and as much as 131.58 (ton/yr)/ $\mathrm{mi}^{2}$ (Anning and others, 2007).

The generalized types of bedrock present in the hydrogeologic areas surrounding the 15 case-study basins, as determined from soils and exposed rocks, are shown on figure 2. Hydrogeologic areas are defined as having coincident groundwater and surface-water basin boundaries, such that they generally surround and contain the flow paths of most water likely to be found in the aquifers of the alluvial basins they include (see text box, "Alluvial Basins and Hydrogeologic Areas").

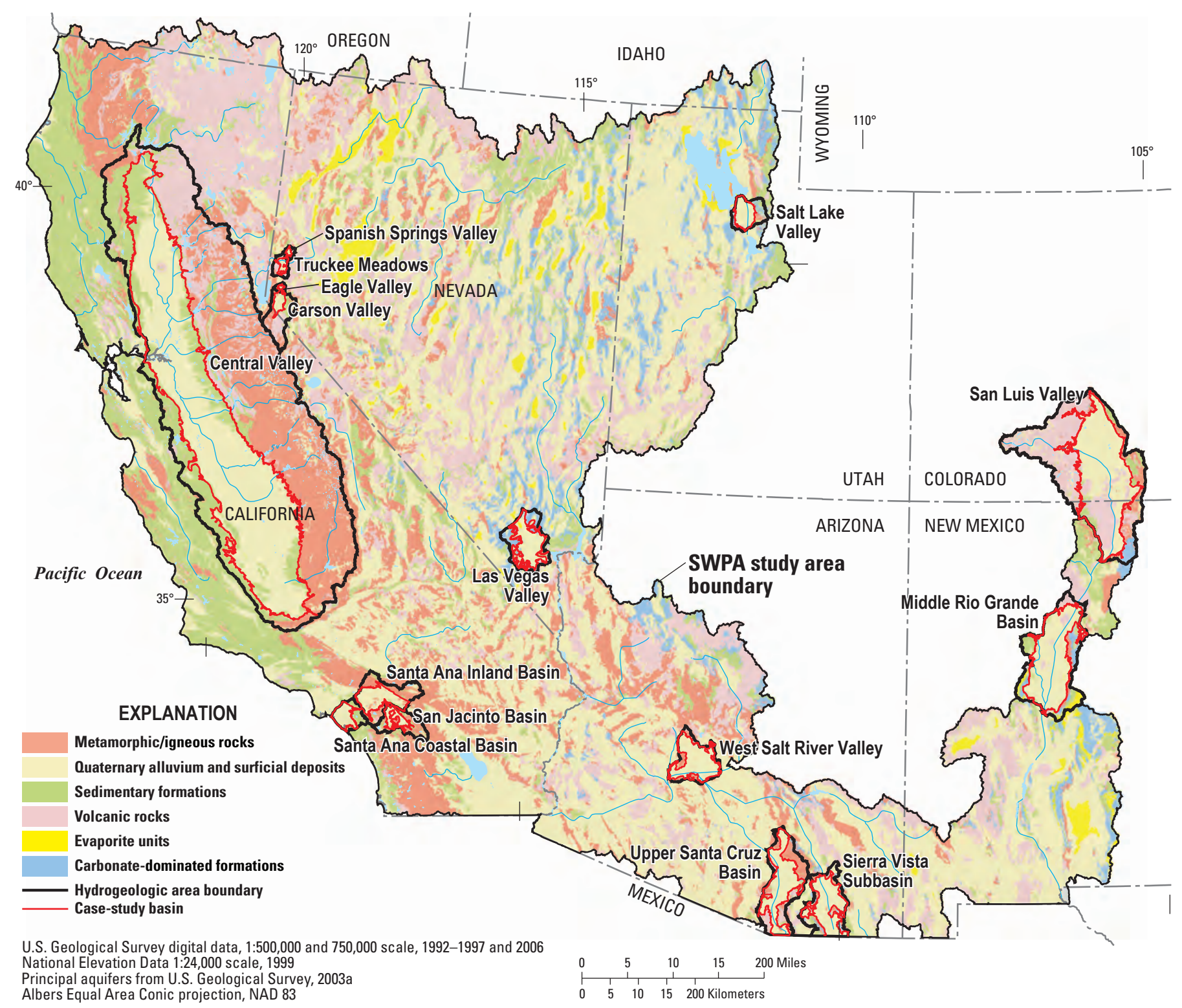

Figure 2. Generalized geology across the Southwest Principal Aquifers study area. 


\section{Alluvial Basins and Hydrogeologic Areas}

Alluvial basins and hydrogeologic areas are important hydrologic control volumes that are related but not coincident (see figure). Alluvial basins in the Southwestern United States are geologic basins defined by areas where blocks of consolidated rock have dropped down relative to

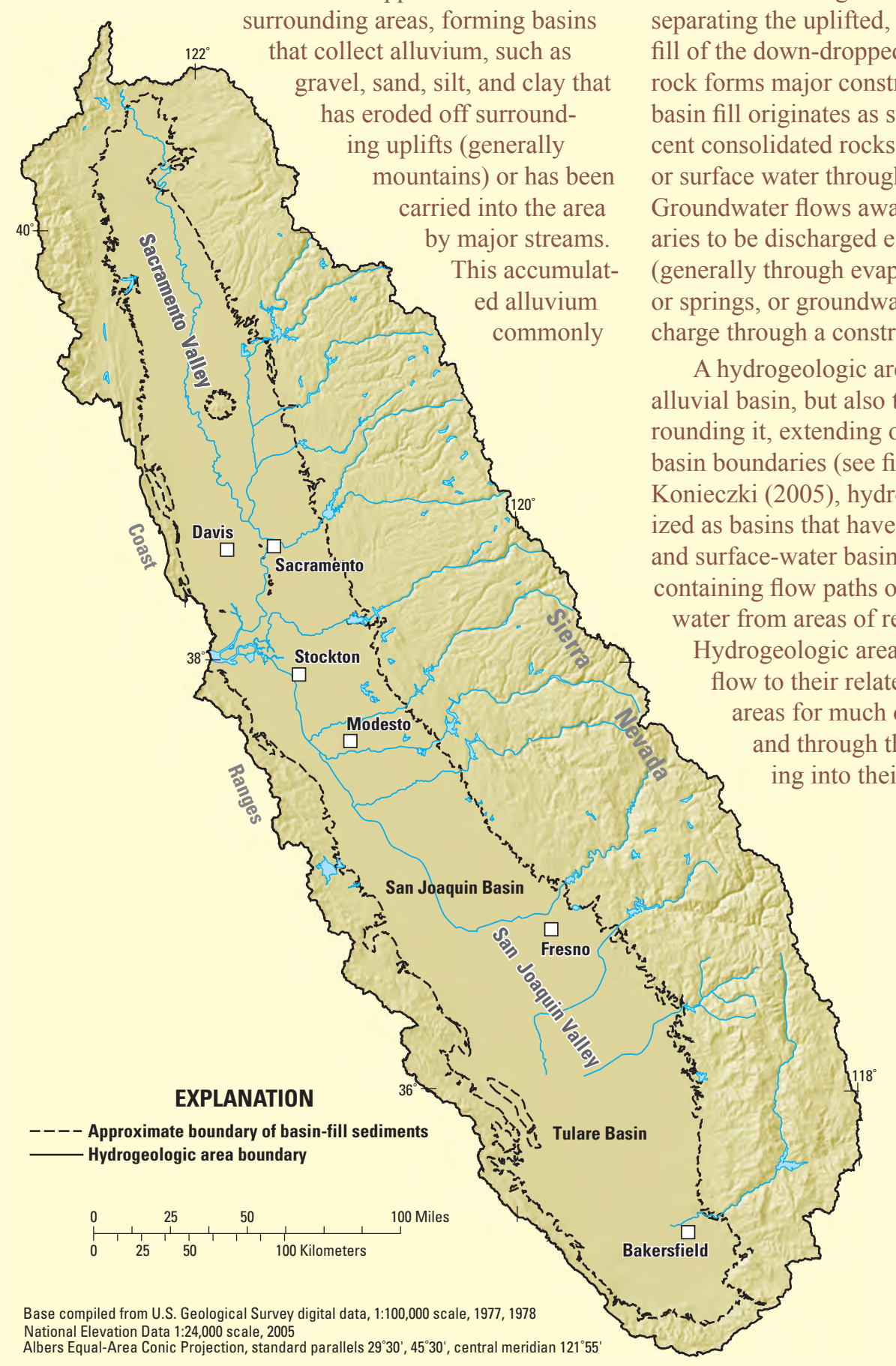

is referred to as 'basin fill' and, where saturated, makes up the primary aquifer of each alluvial basin. As a result, each alluvial basin typically can be considered not only a geologic basin, but also a groundwater basin. The boundaries of alluvial basins generally are defined along major faults separating the uplifted, consolidated rocks from the basin fill of the down-dropped blocks, or where consolidated rock forms major constrictions. Groundwater within the basin fill originates as subsurface recharge from adjacent consolidated rocks or as infiltration of precipitation or surface water through soils, streams, or lakes/ponds. Groundwater flows away from most alluvial-basin boundaries to be discharged either toward the center of the basin generally through evapotranspiration, discharge to streams or springs, or groundwater pumping) or as subsurface disconstriction to an adjacent alluvial basin. figure). As stated in Anning and and surface-water basin boundaries, surrounding and ntaining flow paths of both surface water and ground ater from areas of replenishment to areas of discharge. Hydrogeologic areas, therefore, provide subsurface inw to their related alluvial basins and are the source eas for much of the surface water flowing into nd through the alluvial basins and (or) infiltrating into their basin-fill aquifers.

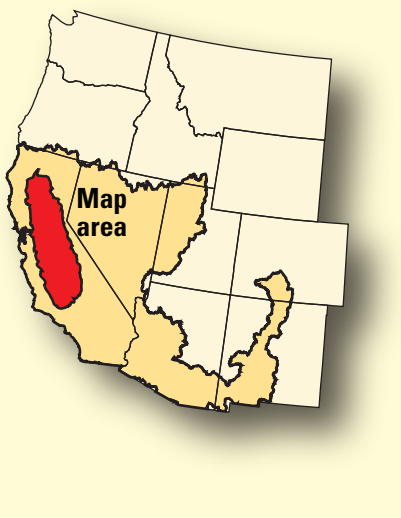


The 15 case-study basins vary widely in terms of the dominant types of surrounding geology (fig. 2 and fig. 3). Metamorphic or intrusive igneous rocks, which generally do not tend to weather easily, cover more than half the land surface in hydrogeologic areas surrounding five case-study basins: Central Valley, San Jacinto, Santa Ana Inland, Upper Santa Cruz, and West Salt River Valley. Metamorphic and igneous rocks generally have relatively low arsenic concentrations of around $5 \mathrm{mg} / \mathrm{kg}$ or less (Smedley and Kinniburgh, 2002) but can have relatively high uranium concentrations, particularly for granite (DeSimone, 2009). Volcanic rocks have been categorized separately from other igneous rocks because they are indicative of environments where some constituents of concern might have been present in fluids and (or) have been sorbed onto geologic materials. Although volcanic rocks generally do not have particularly high concentrations of arsenic, they commonly have been implicated in the occurrence of high-arsenic groundwater, possibly because of other chemical characteristics (such as higher $\mathrm{pH}$ ) of groundwater typically associated with volcanic rocks (Smedley and Kinniburgh, 2002) or because arsenic is more readily mobilized from volcanic rocks and derived sediments (Spencer, 2002). Uranium in volcanic rocks typically occurs at relatively high concentrations, 5 to 50 times higher than in granite (Ulmer-Scholle, 2009). Volcanic rocks cover about 40 percent or more of the land surface in the hydrologic areas surrounding the Carson Valley, San Luis Valley, Spanish Springs Valley, and Truckee Meadows.

For this analysis, rock types other than metamorphic/ igneous or volcanic have been divided into the following four classes: Quaternary alluvium and surficial deposits, sedimentary formations (sandstone, siltstone, mudstone, and (or) shale other than Quaternary alluvium or surficial deposits), carbonate-dominated formations, and evaporite units. Sedimentary formations, which generally erode relatively easily but commonly do not readily undergo chemical weathering, cover 46 percent or more of the land surface in the hydrogeologic areas surrounding the Eagle Valley and Santa Ana Coastal Basin. On average, sedimentary formations are enriched in arsenic relative to igneous rocks, reflecting the presence of minerals or other materials that contain arsenic in their structure or through sorption (Smedley and Kinniburgh, 2002); with the exception of shales, most sedimentary formations have relatively low uranium concentrations (Ulmer-Scholle, 2009). Unconsolidated Quaternary alluvium, which covers no more than 14 percent of the land surface in the hydrogeologic area surrounding any of the case-study basins, has similar chemical characteristics to sedimentary formations. Carbonate-dominated formations, which can weather quite easily, cover about 60 percent of the hydrogeologic area surrounding the Las Vegas Basin. Although carbonates can sorb constituents of concern under some conditions, arsenic concentrations are generally low (Smedley and Kinniburgh, 2002). The hydrogeologic areas surrounding the remaining basins (Middle Rio Grande, Salt Lake Valley, and Sierra Vista subbasin) have no single dominant rock type; metamorphic/non-volcanic igneous, sedimentary, and carbonate rocks each cover at least 10 percent of the hydrogeologic area surrounding each of these basins. Evaporite units, which tend to weather very easily but do not generally sorb constituents of concern, also cover more than 10 percent of the hydrogeologic area surrounding the Middle Rio Grande Basin.

Although not themselves sources of natural contaminants, some faults (particularly faults with large offsets that have resulted in the juxtaposition of rocks of very different age and composition) appear likely to facilitate localized upward movement of geothermal and (or) highly mineralized groundwater. This upward movement results in the transport of natural contaminants from great depth into shallower aquifers used for water supply. In the Middle Rio Grande Basin, the Salt Lake Valley, and the Upper Santa Cruz Basin, higher concentrations of dissolved solids and individual constituents of concern such as arsenic have been observed near major faults, sometimes in association with anomalously warm water temperatures. However, in some cases, faults may actually act as barriers to groundwater flow, thereby impeding mixing between waters of differing composition.

Other factors that can influence the quantity of natural contaminants transported into basin-fill aquifers include evapotranspiration (whereby natural contaminants become increasingly concentrated in surface or soil water) and hydraulic gradients (which determine where water recharges/ discharges and the direction in which groundwater flows). For example, evapotranspiration can result in the build-up of naturally occurring dissolved constituents, including nitrate, in the unsaturated zone in areas where groundwater recharge is not occurring. If a change (either natural or human-induced) subsequently results in the movement of recharge water through that unsaturated zone, the dissolved constituents that are present can be leached to the groundwater in large concentrations. Other ways in which evapotranspiration and hydraulic gradients can influence water quality are discussed in detail in later sections of this report.

\section{Sources of Human-Related Contaminants}

Human activities that can release contaminants into the environment fall into two broad land-use categories - agricultural and urban. Although some contaminants commonly can be released by either agricultural or urban activities, other potential contaminants tend to be used predominantly in only one of these two land-use categories. The dominant types of potential contaminant releases - diffuse or point-source-also can differ, as described in this section. Ideally, in an assessment of the potential for a specific chemical to contaminate groundwater, data on the quantity and location of the use of that particular chemical within the area of interest would be utilized. However, chemical-use data usually are not available at the required spatial and temporal scales. Data for agricultural and urban land use (which are widely available) typically make a reasonable surrogate for chemical-use data because the types of chemicals and potential forms of release associated with these land uses are fairly well known. 


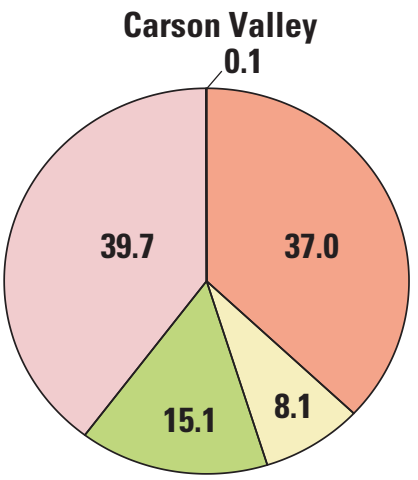

Middle Rio Grande Basin
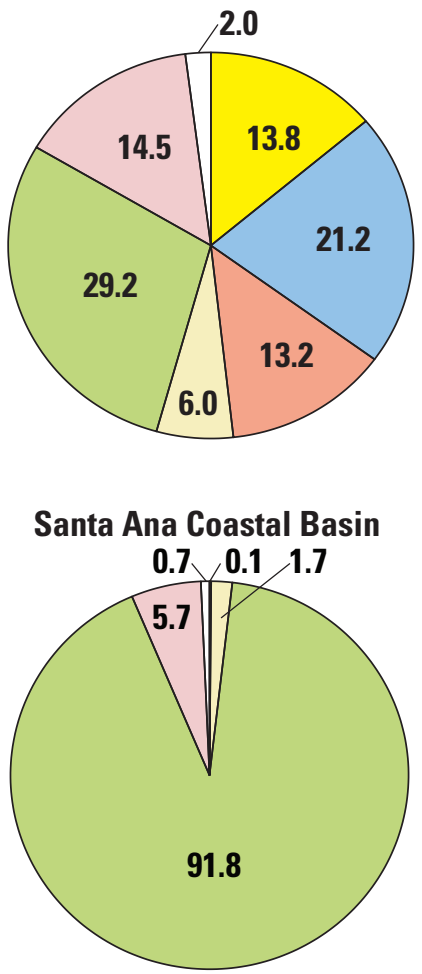

Truckee Meadows

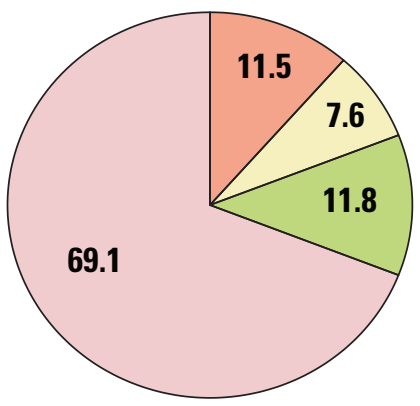

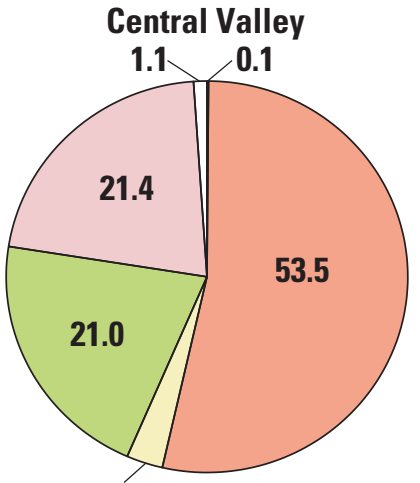

2.9

Salt Lake Valley
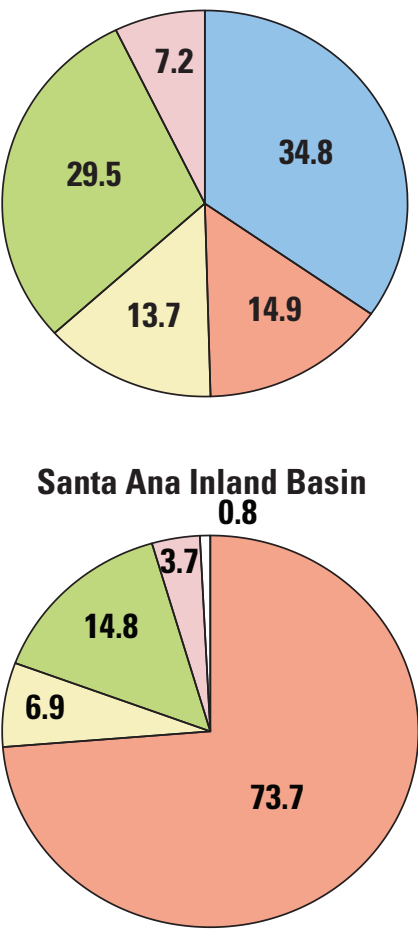

Upper Santa Cruz Basin

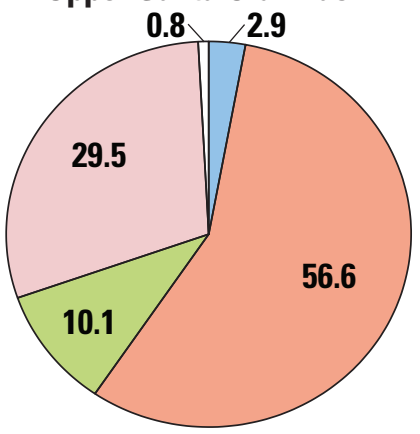

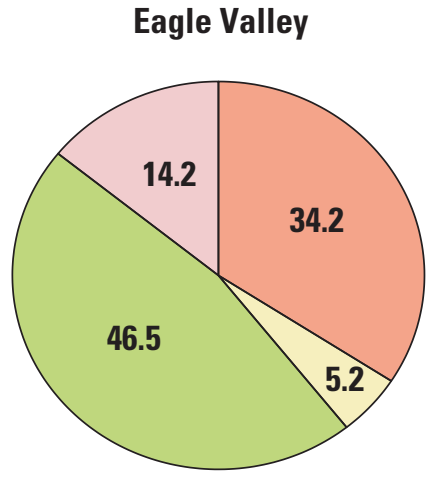
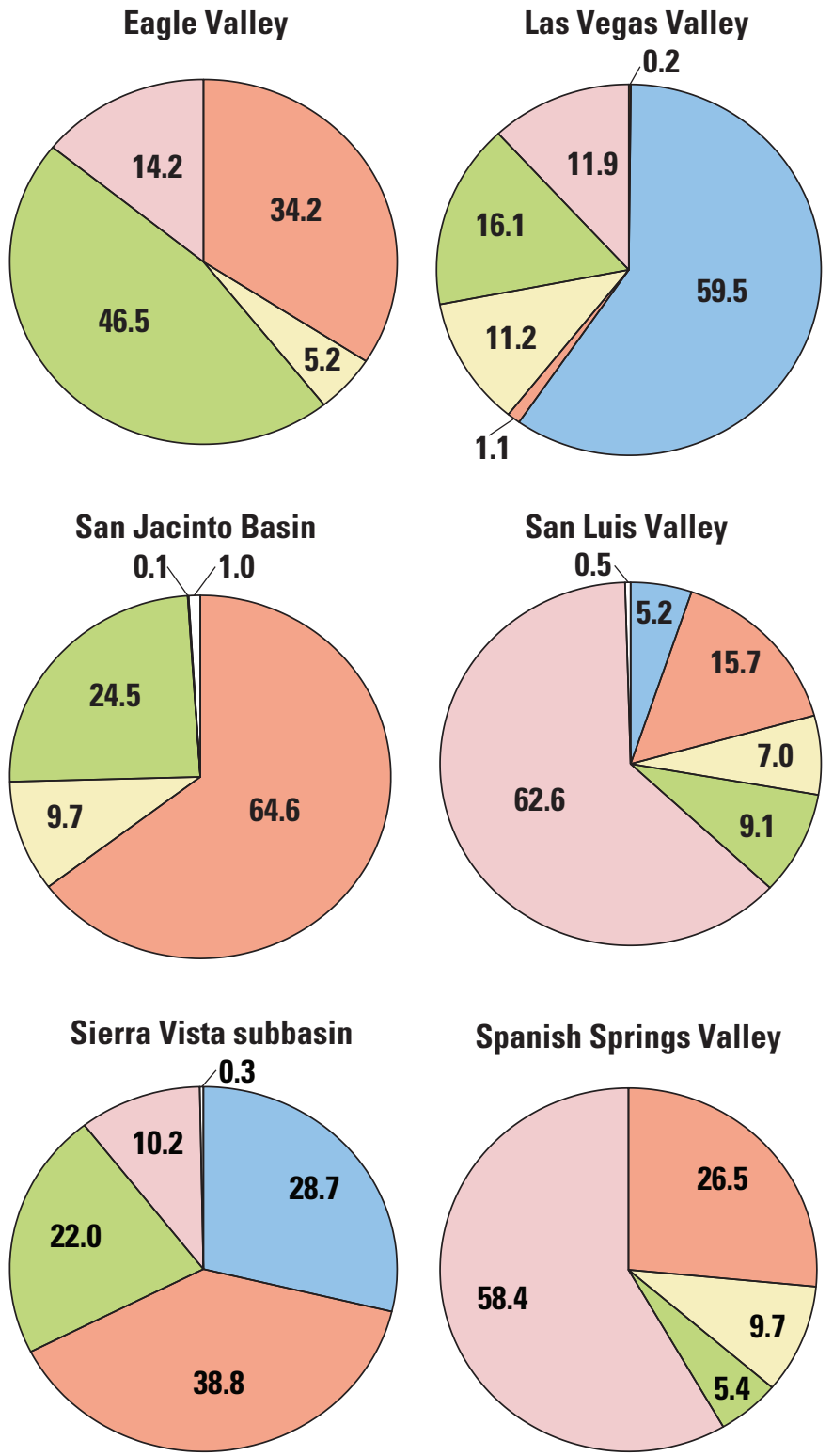

Spanish Springs Valley

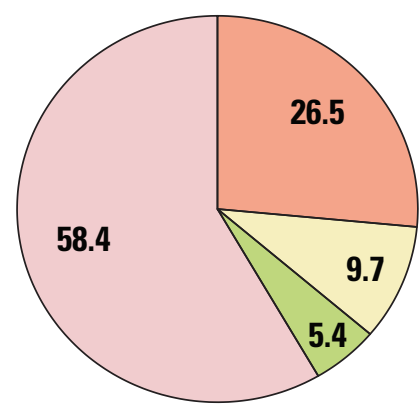

West Salt River Valley

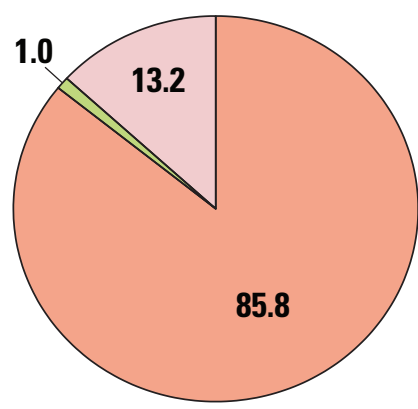

\section{EXPLANATION}

Generalized rock type-Value shown is percent of generalized rock type

Metamorphic/igneous rocks

Quaternary alluvium and surficial deposits

Sedimentary formations

Volcanic rocks

Evaporite units

Carbonate-dominated formations

Other/unknown

Figure 3. Categorization of generalized geology surrounding the 15 case-study basins in the Southwest Principal Aquifers study area. 


\section{Agricultural Sources}

Crop yields often are enhanced through the use of fertilizers and pesticides (including herbicides, insecticides, and (or) fungicides). Widespread use of these compounds, however, results in the potential for agricultural land to be a considerable source of groundwater contaminants. In general, agricultural activity is considered to be a potential diffuse source of contamination - meaning that potential contaminants are applied to the land across broad areas; however, point-source contamination can also be associated with agricultural activity, such as through spills at sites where agricultural chemicals are stored or handled. The application of irrigation water, which is used on essentially all cropland in the SWPA study area, provides a potential driving force for the movement of chemicals applied to crops through the soil zone and into the groundwater. In addition, evapotranspiration of irrigation water applied to fields concentrates solutes in the soil and increases the dissolvedsolids concentrations of excess irrigation water that recharges the groundwater system. Dissolved-solids concentrations of shallow groundwater in agricultural areas also can be affected by agricultural practices if irrigation raises the water table close enough to the land surface to increase evapotranspiration, which has historically occurred in the Middle Rio Grande Basin and San Luis Valley.

Agricultural chemical use and, therefore, the potential availability of associated contaminants differ among crop types because of variability in the required nitrogen input and in the types of pests to which a crop is susceptible. The most common groundwater contaminant associated with fertilizer application is nitrogen (particularly in the form of nitrate), which is more mobile in soil than other fertilizer components such as phosphorus. Paul and others (2007) found that nitrate concentrations exceeded the U.S. Environmental Protection Agency (USEPA) drinking-water standard of $10 \mathrm{mg} / \mathrm{L}$ in more than 25 percent of all shallow groundwater samples collected from agricultural areas across seven alluvial basins in the SWPA study area. Pesticides vary with respect to their active ingredients, some of which are much more mobile and (or) persistent - and, therefore, more likely to be transported to groundwater - than others. Various pesticide compounds known as degradates, or daughter products, form in as little as a few days as the pesticides applied to crops break down. Some VOCs - particularly fumigants - also are used on crops and can be transported to groundwater. Paul and others (2007) found that the most commonly detected pesticides were simazine, atrazine, and diuron; deethylatrazine, which is a degradate of atrazine, was detected more commonly than its parent compound. Dibromochloropropane (DBCP) was the most commonly detected fumigant pesticide (belonging to the VOC class of compounds), even though it was detected only in the Central Valley.

Agricultural land use throughout the SWPA study area is mapped in figure 4. Although the mapped agricultural land consists primarily of irrigated cropland, livestock operations (such as confined animal-feeding operations, which can be sources of elevated dissolved solids and nutrients in particular) are included. Crops tend to be cultivated on relatively flat valley floors, particularly along rivers and streams that can be used to supply irrigation water to fields. Among the 15 case-study basins, agricultural land use ranges from essentially none in the Las Vegas Valley to about 61 percent in the Central Valley (fig. 5). Other basins with about 20 percent or more land under cultivation are the Carson Valley, San Jacinto Basin, and West Salt River Valley. Among basins having irrigated agriculture, irrigated acreage ranges from just over 200 in Eagle Valley to nearly 7.8 million in the Central Valley (fig. 6). These values represent recent agricultural land use, which in some basins is substantially less extensive than in the past, prior to widespread replacement of agricultural land by urban development.

The most common crops being cultivated in various basins are listed in table 4 . Alfalfa, which does not require high nitrogen inputs but is commonly treated with the herbicide diuron, is cultivated in several basins. Crops requiring higher nitrogen inputs, such as cotton and grains, also are grown in the SWPA case-study basins. Relatively high use of herbicides (including diuron) and insecticides is required for cotton. Herbicide use also is common on grains - atrazine is particularly associated with corn cultivation. Simazine use is common on vegetables and in orchards and vineyards. The fumigant DBCP was used on vegetables and ornamental crops until it was banned for these uses in the late 1970s. As evidenced by recent detections of DBCP in groundwater of the Central Valley (Burow and others, 2008), historical use of banned pesticides can be important for groundwater quality even decades later if the pesticide or its degradates are particularly persistent.

\section{Urban Sources}

Urban land is associated with the manufacturing, storage, and use of a wide variety of chemical types, including VOCs, pesticides, and fertilizers. Urban activity can be a source of either point-source or diffuse contamination of groundwater. Contamination by VOCs is more commonly associated with point sources, such as leaky storage tanks, landfills, or accidental spills. Such point sources are generally more likely to be present in industrial or commercial areas than residential areas. Infiltration of stormwater runoff is another potential source of VOCs to groundwater that can be either diffuse or focused, depending on whether infiltration occurs across broad areas or only through streambeds/channels. Runoff that infiltrates subsequent to road-salt application can be a substantial source of dissolved solids in colder urban areas like the Salt Lake Valley. Contamination by pesticides or fertilizers can be associated either with point sources or with diffuse sources (particularly use on urban turf grasses); pesticides also are commonly used along roadways and utility rights-of-way. Evapotranspiration of irrigation water applied to turf grasses also can result in increased dissolved-solids concentrations in groundwater. Septic tanks or leaky sewer lines can be a source of nitrogen, VOCs, and (or) dissolved solids to groundwater in urban areas. For example, elevated nitrate concentrations in groundwater of the Spanish Springs Valley have been attributed to seepage from septic tanks. 


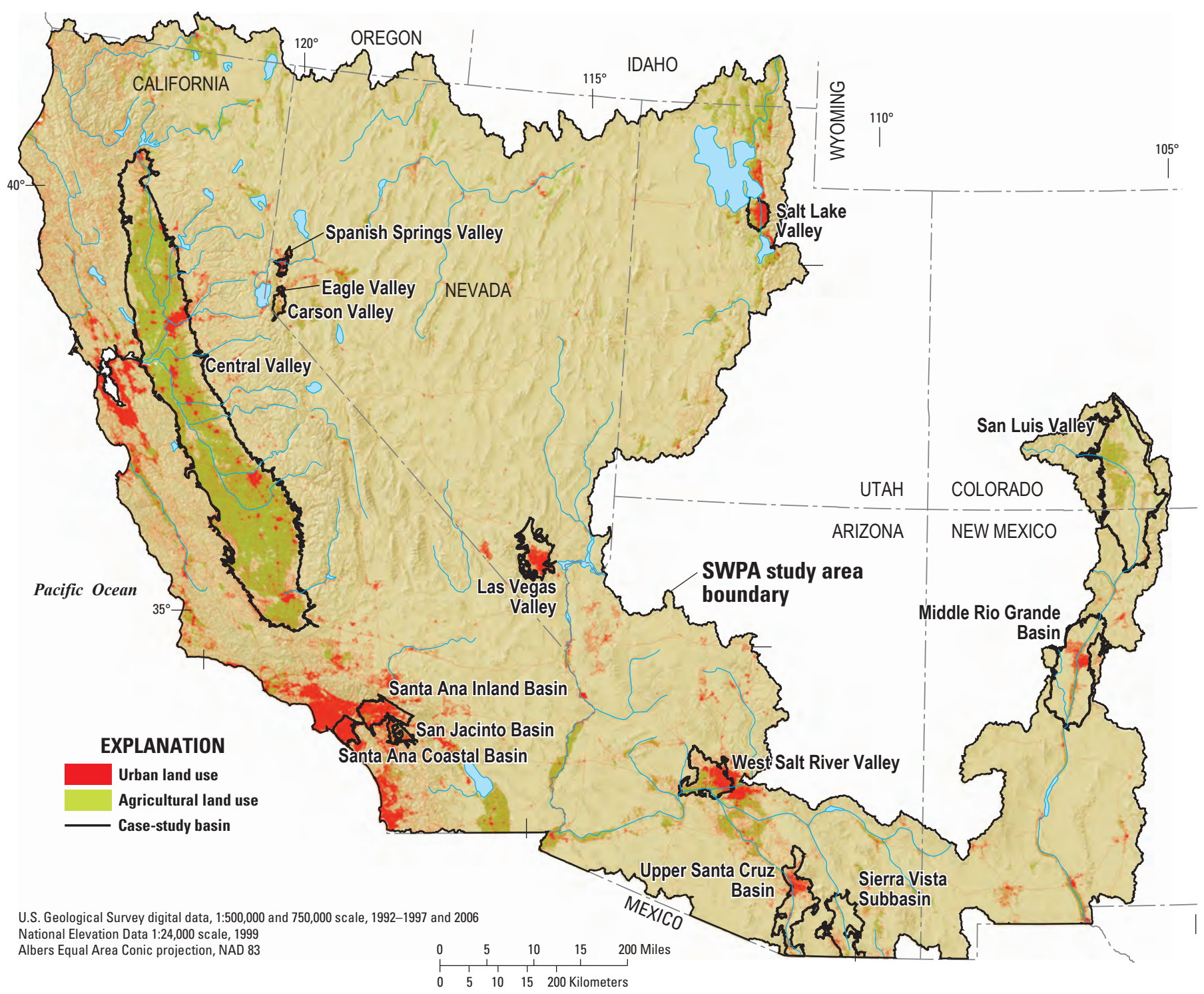

Figure 4. Land use in the Southwest Principal Aquifers study area.

When comparing shallow groundwater quality between agricultural and urban areas of the SWPA study area, Paul and others (2007) found a few differences in the most commonly detected contaminants. Although nitrate was detected in urban areas, concentrations exceeded the USEPA drinking-water standard of $10 \mathrm{mg} / \mathrm{L}$ in less than 10 percent of all samples (compared with 25 percent in agricultural areas). Prometon - an herbicide that is not applied to crops - was the most commonly detected pesticide in urban areas, although the degradate deethylatrazine was detected even more frequently. Atrazine and simazine also were commonly detected in urban samples (in 24 and 17 percent of samples, respectively).

Among VOCs, trichloromethane (chloroform) was the most commonly detected compound in urban areas (29 percent of samples). Tetrachloroethene (PCE), trichloroethene (TCE), and methyl tert-butyl ether (MTBE) were each detected in 5 percent or more of samples.
Urban land use throughout the SWPA study area is mapped in figure 4. Urban areas are located in a variety of topographic settings, including along basin margins. Among the 15 case-study basins, urban land use ranges from about 2 percent of total land area in the San Luis Valley to more than 90 percent in the Santa Ana Coastal Basin (fig. 5); 9 of the basins have more than 25 percent urban land. In 2005, population among the 15 basins ranged from less than 15,000 in Spanish Springs Valley to more than 6 million in the Central Valley (fig. 7A); population density ranged from 15 persons per square mile in the San Luis Valley to 7,000 persons per square mile in the Santa Ana Coastal Basin (fig. 7A). The fraction of the basin population on septic systems (as opposed to sewer systems) in 2000 also ranged widely, from only about 2 percent in the Santa Ana Coastal Basin to more than 90 percent in Spanish Springs Valley (fig. 7B). 


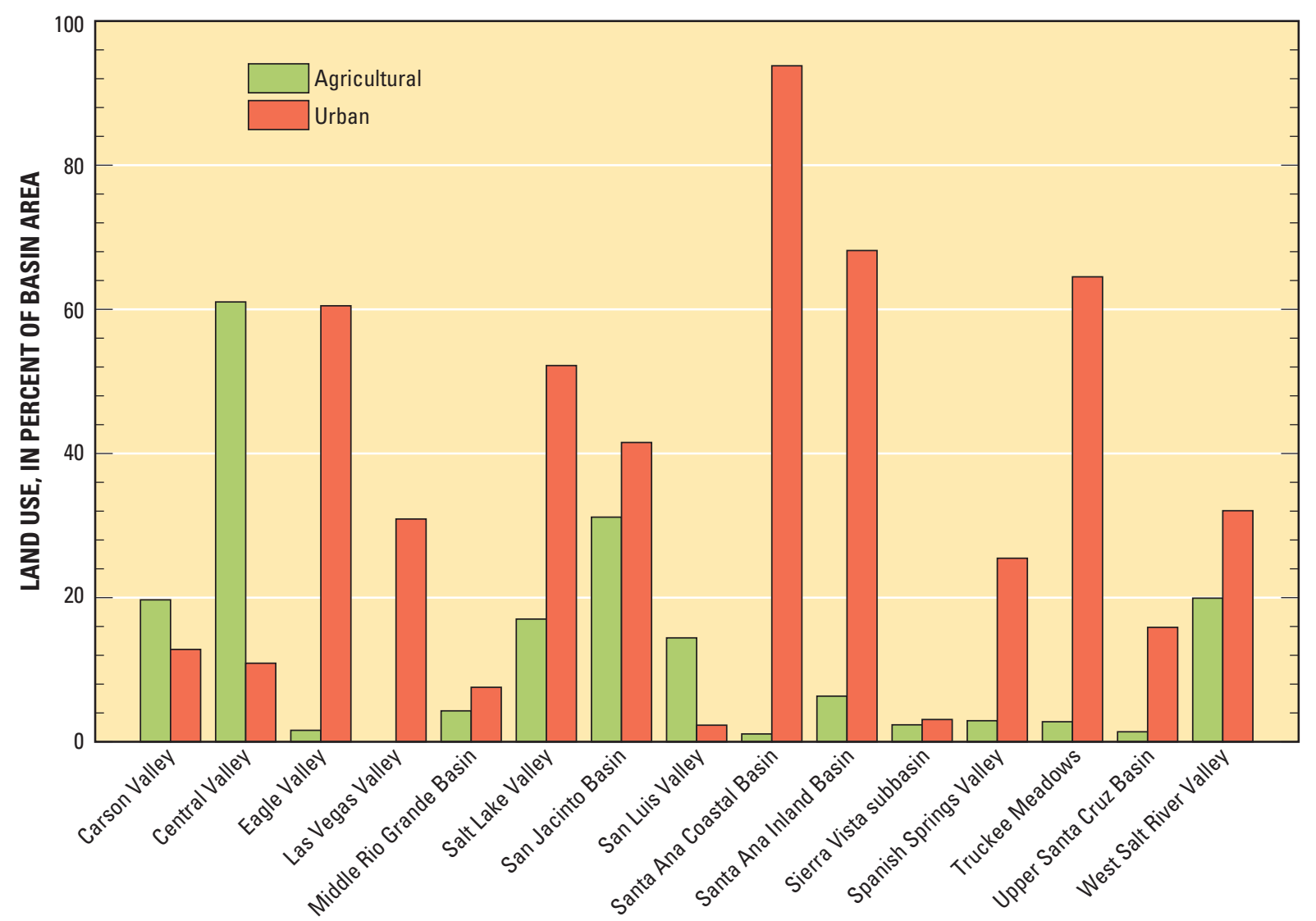

Figure 5. Categorization of land use in the 15 case-study basins in the Southwest Principal Aquifers study area.

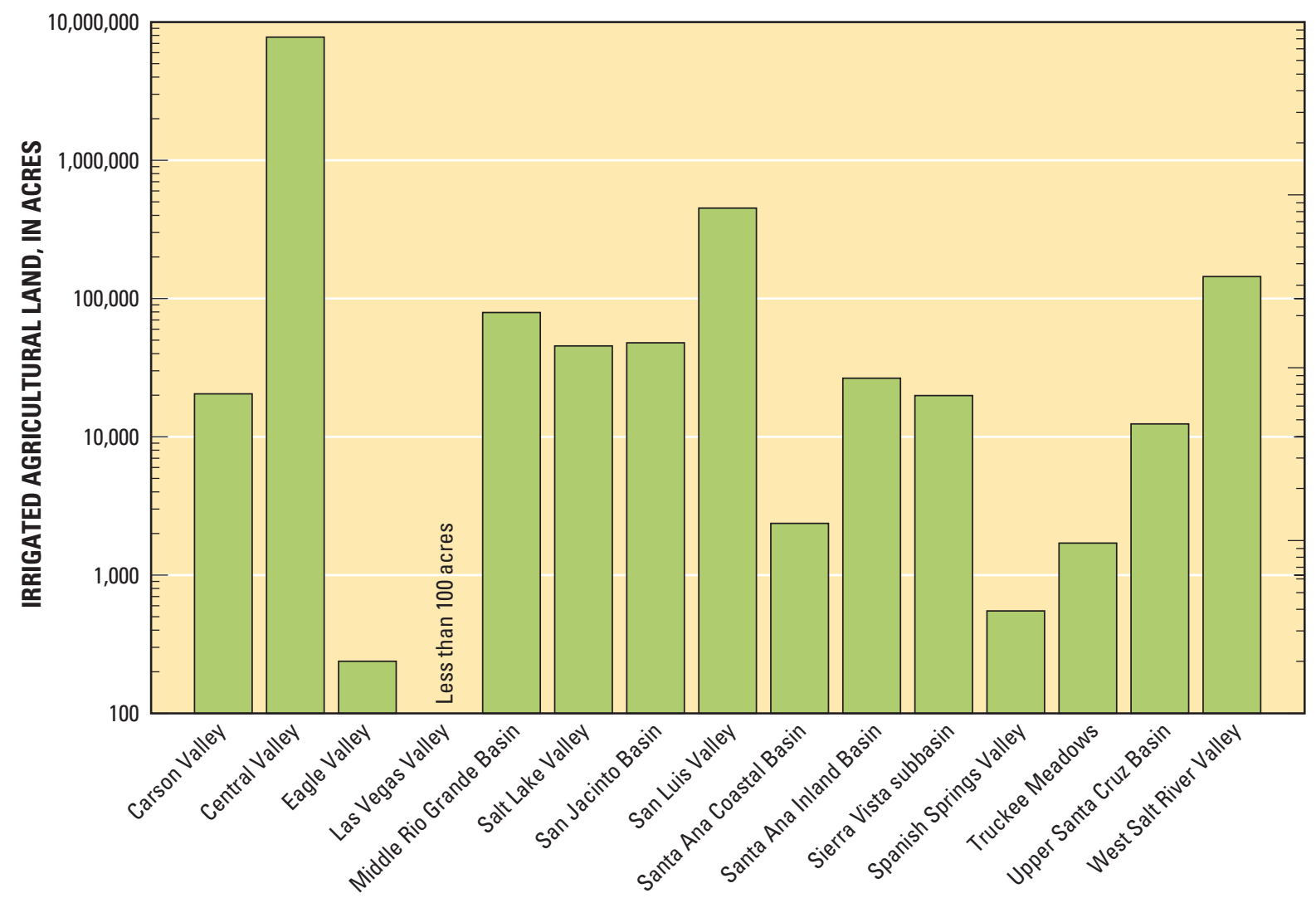

Figure 6. Irrigated acreage in the 15 case-study basins in the Southwest Principal Aquifers study area. 
Table 4. Major agricultural land cover in the 15 case-study basins in the Southwest Principal Aquifers study area.

\begin{tabular}{|c|c|c|}
\hline Basin & $\begin{array}{l}\text { Percent } \\
\text { agricultural } \\
\text { land in } \\
2001\end{array}$ & Major agricultural land cover \\
\hline Carson Valley & 43 & alfalfa, pasture, flax \\
\hline Central Valley & 57 & $\begin{array}{l}\text { grains, hay, cotton, vegetables, citrus, } \\
\text { fruit, nuts, corn, rice, grapes }\end{array}$ \\
\hline Eagle Valley & 7 & pasture \\
\hline Las Vegas Valley & 0 & no appreciable agriculture in basin \\
\hline Middle Rio Grande & 2 & $\begin{array}{l}\text { alfalfa, planted pasture, vegetables, } \\
\text { corn }\end{array}$ \\
\hline Salt Lake Valley & 7 & alfalfa, pasture, grains \\
\hline San Jacinto & 38 & alfalfa, hay, wheat \\
\hline San Luis Valley & 20 & $\begin{array}{l}\text { alfalfa, native hay, barley, wheat, } \\
\text { potatoes, vegetables }\end{array}$ \\
\hline Santa Ana Coastal & 5 & pasture, cropland, orchards, vineyards \\
\hline Santa Ana Inland & 8 & $\begin{array}{l}\text { field crops, pasture, orchards, } \\
\text { vineyards, dairy cows }\end{array}$ \\
\hline Sierra Vista Subbasin & 1 & hay, nuts, vegetables \\
\hline Spanish Springs Valley & 5 & alfalfa, pasture \\
\hline Truckee Meadows & 3 & alfalfa, meadow hay, pasture \\
\hline Upper Santa Cruz & 1 & $\begin{array}{l}\text { cotton, hay, grains, fruits, nuts, } \\
\text { vegetables }\end{array}$ \\
\hline West Salt River Valley & 13 & hay, cotton, grains, vegetables \\
\hline
\end{tabular}

\section{Natural Recharge and Discharge}

The types and quantities of recharge to and discharge from the groundwater system of an alluvial basin exert strong controls on the quality of groundwater in that basin. The potential for transport of natural and (or) human-related contaminants into and through the groundwater system is dependent on the areal location where recharge occurs (basin margins or valley floor, for example), the depth at which the recharge originates (at the land surface or in the subsurface, for example), and the residence time of the water that has recharged. Discharge mechanisms also are important in controlling whether dissolved constituents concentrate in groundwater through time or are flushed out of the aquifer system. This section focuses on natural recharge and discharge mechanisms that have existed in the alluvial basins of the SWPA study area over much longer time scales than human mechanisms. Under modern conditions, even recharge occurring through natural mechanisms can transport humanrelated contaminants to groundwater, as discussed below.

\section{Sources and Mechanisms of Natural Recharge}

The locations of recharge to the basin-fill aquifer of an individual basin can be divided into two broad areas (fig. 8): basin margins (which, for the purposes of this study, include the alluvial slopes that typically occur along mountain fronts) and valley floors (relatively flat areas onto which alluvial slopes grade). The types of natural recharge that commonly occur along basin margins (fig. 8A and text box on "Hydrogeologic Characteristics of the San Luis Valley") include subsurface groundwater inflow from adjacent basins and (or) mountain blocks and infiltration of mountain-front streams, in addition to some direct infiltration of precipitation. Along basin margins, sediments tend to be conducive to groundwater recharge because they are mostly coarse-grained and poorly sorted, with relatively few interbedded clay layers. Hydraulic gradients in the aquifer along basin margins tend to be downward, enhancing movement of recharge to greater depths. On valley floors, more common interbedded clay layers combined with lower rates of precipitation and higher rates of evapotranspiration tend to result in less groundwater recharge; also, generally upward hydraulic gradients in the aquifer inhibit the downward movement of any recharge that does occur. Where recharge does occur on valley floors, it is likely to be from infiltration of surface water in streams or arroyos, although lakes or other sources of focused recharge also can be present. In some basins with relatively high rates of precipitation (and in higherelevation basins with substantial snowfall and snowmelt [Flint and Flint, 2007]) recharge can occur from direct infiltration of precipitation on valley floors (fig. 8A). The relative quantities of water recharging through these various mechanisms play a role in determining aquifer susceptibility.

Subsurface groundwater inflow can enter the basin from a neighboring alluvial basin or other type of groundwater basin. This inflow tends to consist primarily of relatively old groundwater that reached the water table at its original recharge location hundreds to thousands of years before entering the alluvial basin of interest. Because of its age, this inflow generally has a low potential to introduce human-related contaminants to the basin-fill aquifer but a relatively high potential to introduce some natural contaminants (such as dissolved solids or arsenic) that are more likely to be present in water that has had long contact times with potentially reactive sediments. For example, subsurface inflow entering the Middle Rio Grande Basin from groundwater basins to the west has elevated concentrations of dissolved solids.

Recharge along mountainous basin margins generally includes infiltration of water from mountain-front streams and groundwater inflow entering the basin fill either in shallow alluvium along streams or from deeper bedrock. Because these various components of recharge are typically difficult to distinguish from each other, this report uses the term "mountain-front recharge" to refer to their combined contribution, even though previous investigations might have labeled deeper groundwater 

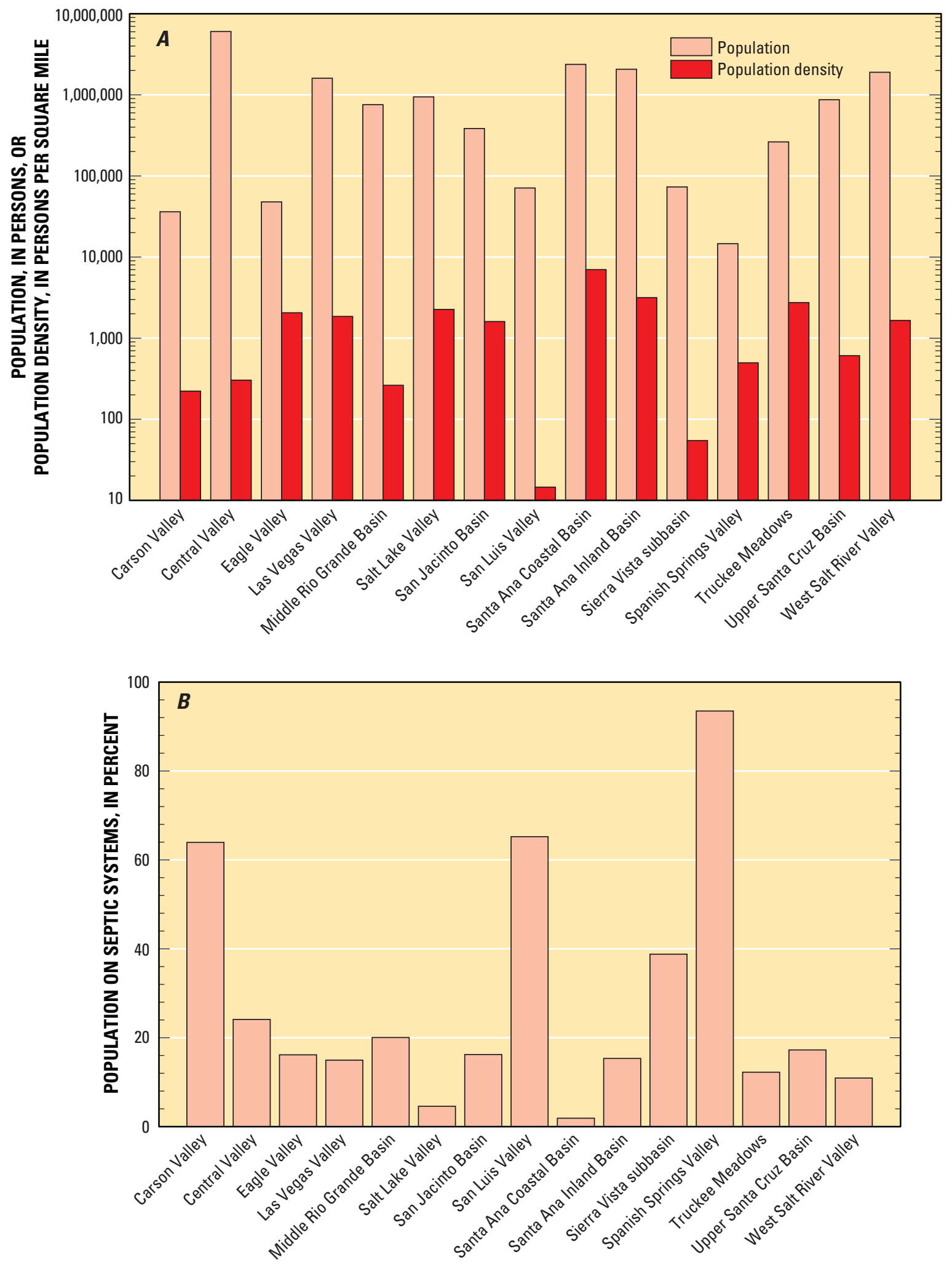

Figure 7. A, total population and population density and $B$, percent of population on septic systems in the 15 case-study basins in the Southwest Principal Aquifers study area. 


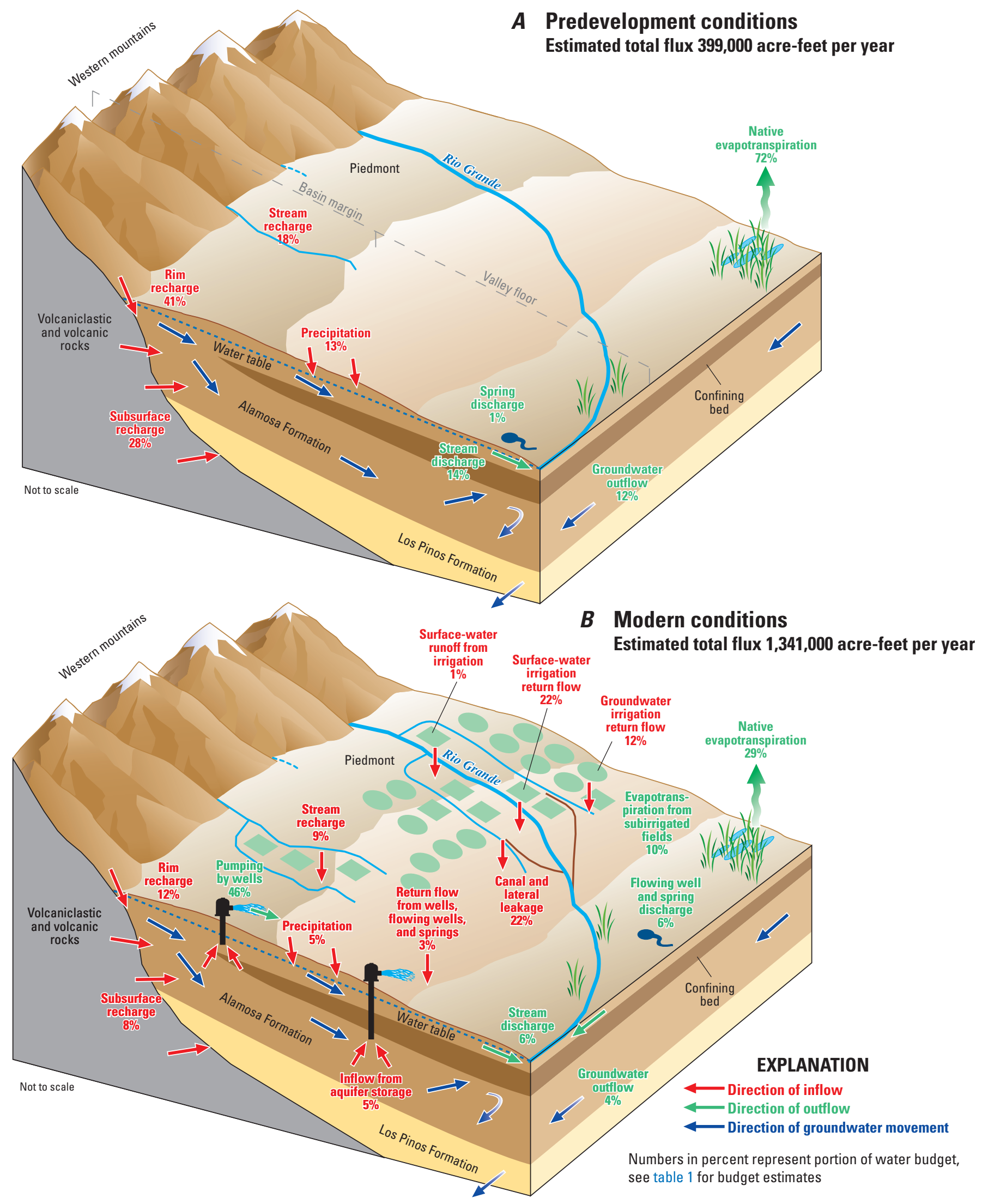

Figure 8. Generalized block diagrams for the Alamosa Basin of the San Luis Valley, Colorado, showing the basin-fill deposits and components of the groundwater system under $A$, predevelopment and $B$, modern conditions. 


\section{Hydrogeologic Characteristics of the San Luis Valley}

The San Luis Valley (the Valley) in southern Colorado and northern New Mexico includes many hydrogeologic features that are found in other parts of the SWPA study area. The Valley has areas that are externally drained through groundwater discharge to a perennial stream (the Rio Grande) and areas that are internally drained through evapotranspiration of groundwater. Depth to water ranges from a few feet in the central part of the Valley floor, where hydraulic gradients are naturally upward, to more than $80 \mathrm{ft}$ along the margins, where hydraulic gradients are naturally downward. Near the margins of the Valley, aquifer materials are relatively permeable and conditions are unconfined, whereas toward the center of the Valley the presence of thick, laterally extensive clay deposits results in confined conditions.

The most current groundwater budget for the San Luis Valley actually applies only to the Colorado part of the Valley, where most of the basin-fill deposits (with a thickness up to about $19,000 \mathrm{ft}$ in places) are located. Under predevelopment conditions, about 70 percent or more of the total annual recharge of 399,000 acre-ft to the basin-fill aquifer occurred along or near the margins of the Valley, generally as mountain-block and mountain-front recharge (fig. 8). Some recharge also occurred through direct infiltration of precipitation on the Valley floor. Discharge under predevelopment conditions was mostly through evapotranspiration.

As a result of land and water development, primarily for agriculture, annual recharge to the basin-fill aquifer in the Valley increased by more than two times, to 1.34 million acre-ft, under modern conditions. More than sixty percent of total recharge now occurs on the Valley floor, primarily through the infiltration of irrigation water from fields and canals, which has resulted in water-level rise in some places. More than half of groundwater discharge occurs through groundwater pumping, which has resulted in the removal of water from aquifer storage and associated groundwater declines in some areas. These changes to the groundwater system have increased the vulnerability of the basin-fill aquifer to some human-related contaminants, as indicated by the widespread occurrence of nitrate concentrations above background levels in shallow parts of the aquifer. inflow as "mountain-block recharge." Mountain-front streams that contribute recharge to basin-fill aquifers in the SWPA study area commonly contain water for only a relatively short distance from basin margins - except during large storm events and (or) snowmelt - because of the presence of coarse basin sediments that result in relatively high infiltration rates. These streams, which typically originate at high elevations inside the hydrogeologic area containing the alluvial basin, receive runoff from precipitation and shallow groundwater inflow from bedrock. In the areas where these streams originate, there tends to be relatively little human activity that could contribute human-related contaminants to the streams, although residential areas in particular can be present. Depending on the rock type across which the stream flows, concentrations of natural contaminants in the stream water could be of concern. Contaminants that are present in the stream and shallow groundwater in associated alluvium can be transported to the basin-fill aquifer during infiltration and recharge. Deeper groundwater inflow from mountain blocks can vary substantially in age, depending particularly on whether flow is through transmissive fractures or the bulk matrix of the bedrock. Depending on the type of bedrock, older groundwater inflow could contain relatively high concentrations of some natural contaminants. For example, elevated arsenic concentrations in the northwestern part of the Middle Rio Grande Basin have been attributed in part to inflow of relatively old, deep groundwater with high arsenic concentrations resulting from contact with volcanic rocks.

Unsaturated-zone studies have indicated that diffuse recharge by means of the direct infiltration of precipitation contributes only minimally to total recharge in most arid and semiarid basins (Walvoord and Scanlon, 2004). However, studies in some individual basins such as the Central Valley (Faunt and others, 2009) have indicated that diffuse recharge from precipitation is a substantial component of natural recharge to the basin-fill aquifer. Precipitation generally is low in concentrations of both natural and human-related contaminants before reaching the land surface, but it can transport contaminants that are present at the surface or in the soil zone to the groundwater. Basin margins typically have less human activity (particularly non-residential activity) than flatter valley floors where agricultural and (or) urban activity can be widespread, providing the potential for a range of contaminants (including dissolved solids, nitrate, VOCs, and pesticide compounds) to be available for transport to the water table. However, in the absence of large quantities of groundwater pumping, the generally upward natural hydraulic gradients beneath valley floors can help to prevent transport of contaminants to substantial depths within the basin-fill aquifer.

Natural streams - perennial and ephemeral_crossing valley floors also are potential major sources of groundwater recharge. Streams that reach the valley floor of an individual 
basin can originate either inside or outside the hydrogeologic area of that basin. Naturally perennial streams in the SWPA study area generally are in hydraulic connection with the aquifer and can either lose or gain water, whereas ephemeral streams (or arroyos) generally are not in hydraulic connection with the aquifer and lose water along most or all of their lengths. Depending on the hydrologic and land-use characteristics of areas along the stream path, input to the stream (which could include runoff, agricultural return flow, or sewage-treatment plant outflow) may or may not have included water with substantial concentrations of natural or humanrelated contaminants that can be transported to the basin-fill aquifer during infiltration. For example, the Rio Puerco, an ephemeral stream that recharges the aquifer across large areas of the Middle Rio Grande Basin, has naturally elevated concentrations of dissolved solids and uranium.

The 15 case-study basins of the SWPA study area differ with respect to the mechanism(s) dominating natural groundwater recharge (fig. 9), based on predevelopment groundwater budgets intended to represent conditions prior to substantial human development (Thiros and others, 2010). These budgets were assembled from recharge studies and (or) groundwater flow models that cover the majority of each basin or, in the case of the Santa Ana Inland Basin, subbasins that together cover the majority of the basin. Because the dominant recharge mechanisms vary by basin, the potential for contaminants to be transported to the aquifer vary as well. Under predevelopment conditions, subsurface groundwater inflow from neighboring alluvial basins provided more than half the recharge only to the Chino subbasin of the Santa Ana Inland Basin. Mountain-front recharge (including inflow from the mountain block) provided more than half the recharge to Carson Valley, Eagle Valley, Las Vegas Valley, Salt Lake Valley, San Jacinto Basin, San Luis Valley, the Sierra Vista subbasin, and Truckee Meadows, and to the Bunker Hill subbasin of the Santa Ana Inland Basin. However, for the San Jacinto Basin, mountain-front recharge dominated for eastern subbasins and the basin as a whole, whereas infiltration of precipitation on the basin and stream loss on the valley floor combined to dominate recharge in western subbasins. In the Central Valley and Spanish Springs Valley, more than half of recharge was categorized as infiltration of precipitation on the basin, although this value for the Central Valley could include recharge from ephemeral streams, particularly in upland areas. Stream loss on the valley floor provided more than half the recharge to the Middle Rio Grande Basin, Santa Ana Coastal Basin, Upper Santa Cruz Basin, and West Salt River Valley. On the basis of this information, natural recharge under predevelopment conditions appears to have occurred mainly along the margins of most basins, but predominantly in the interior of a few basins (or subbasins), particularly in California, Arizona, and New Mexico. Changes in the contributions from various recharge sources under modern conditions will be discussed in the later section on artificial recharge.

\section{Quantities of Natural Recharge}

The quantity of annual recharge to a basin-fill aquifer plays a role in aquifer vulnerability in several ways. For example, recharge quantity is a determining factor in the traveltime of water through an aquifer-when comparing two aquifers of equal volume and assuming no change in storage, groundwater would move more quickly on average through the aquifer with the higher recharge rate, resulting in a younger average groundwater age. Recharge quantity can also affect the depth to water-if the recharge rate to an individual aquifer increased but discharge did not undergo a corresponding increase, there would be a change in storage that would result in the water table being on average closer to the land surface. In addition, recharge provides a driving force for moving contaminants from the land surface to the water table - with the exception of flow by a pure nonaqueous phase liquid or gaseous phase, contaminants at the land surface will reach the underlying water table only if recharge is occurring at the location where those contaminants are present. However, recharge also provides a means for lowering contaminant concentrations through dilution - for the same mass of available contaminant, more recharge water will result in a lower average contaminant concentration.

To compare recharge quantities among alluvial basins, the annual volume of recharge to an individual basin would ideally be normalized to the volume of the aquifer in that basin. However, even within an individual basin, the thickness of the basin-fill aquifer typically varies substantially and is not well defined at all points because of insufficient data. Therefore, for the purpose of comparison of recharge quantities among basins in this study, the annual volume of recharge to an individual basin was normalized to the surficial area of the aquifer in that basin (fig. 10). Although not ideal, this means of normalizing recharge quantities helps to account for the vast differences in size among the 15 case-study basins, so that order-of-magnitude comparisons can reasonably be made. On the basis of the recharge per unit area calculated using information from recharge studies and (or) groundwater flow models of the basins (fig. 10), the four case-study basins - or parts of basins - that receive the most natural recharge (more than $8.0 \mathrm{in} / \mathrm{yr}$ ) are the Eagle Valley, Salt Lake Valley, Santa Ana Coastal Basin, and Bunker Hill subbasin of the Santa Ana Inland Basin. With the exception of Eagle Valley, all these areas are on the windward side of major mountain ranges and would, therefore, be expected to have relatively high precipitation rates. These basins also are mostly adjacent to areas with low values of the aridity index (annual precipitation divided by potential evapotranspiration, as calculated and mapped for this report; fig. 11), indicating the potential for a greater fraction of precipitation to reach the water table than in areas with a high aridity index. The seven basins with natural recharge rates of less than $1.3 \mathrm{in} / \mathrm{yr}$ are the Las Vegas Valley, Middle Rio Grande Basin, San Jacinto Basin, Sierra Vista subbasin, Spanish Springs Valley, Upper Santa Cruz Basin, and West Salt River Valley, most of which are in the southeastern part of the SWPA study area (in southern Nevada, Arizona, and New Mexico), where the aridity index tends to be highest. 


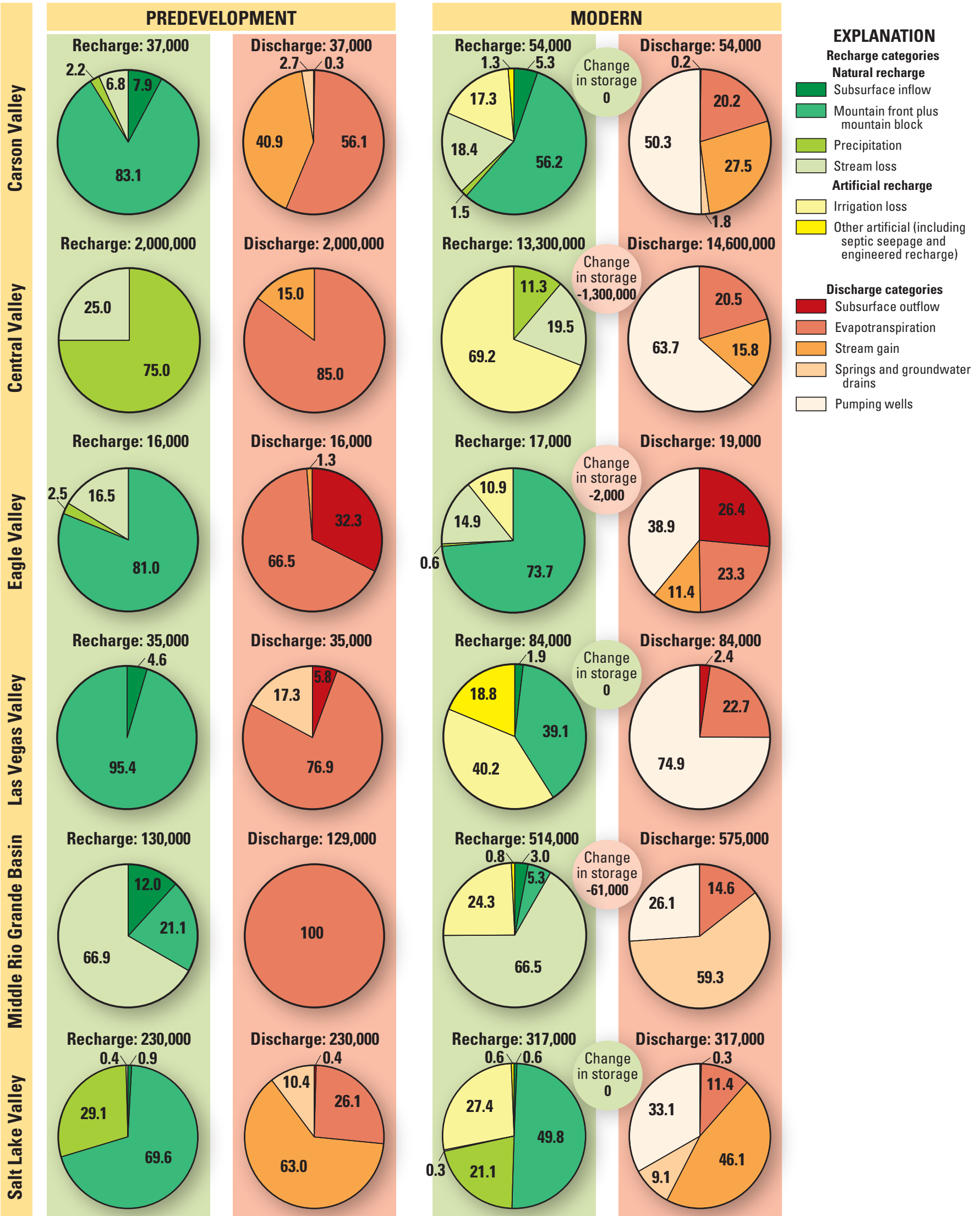

Figure 9. Categorization of recharge and discharge mechanisms for the 15 case-study basins in the Southwest Principal Aquifers study area under predevelopment and modern conditions. 


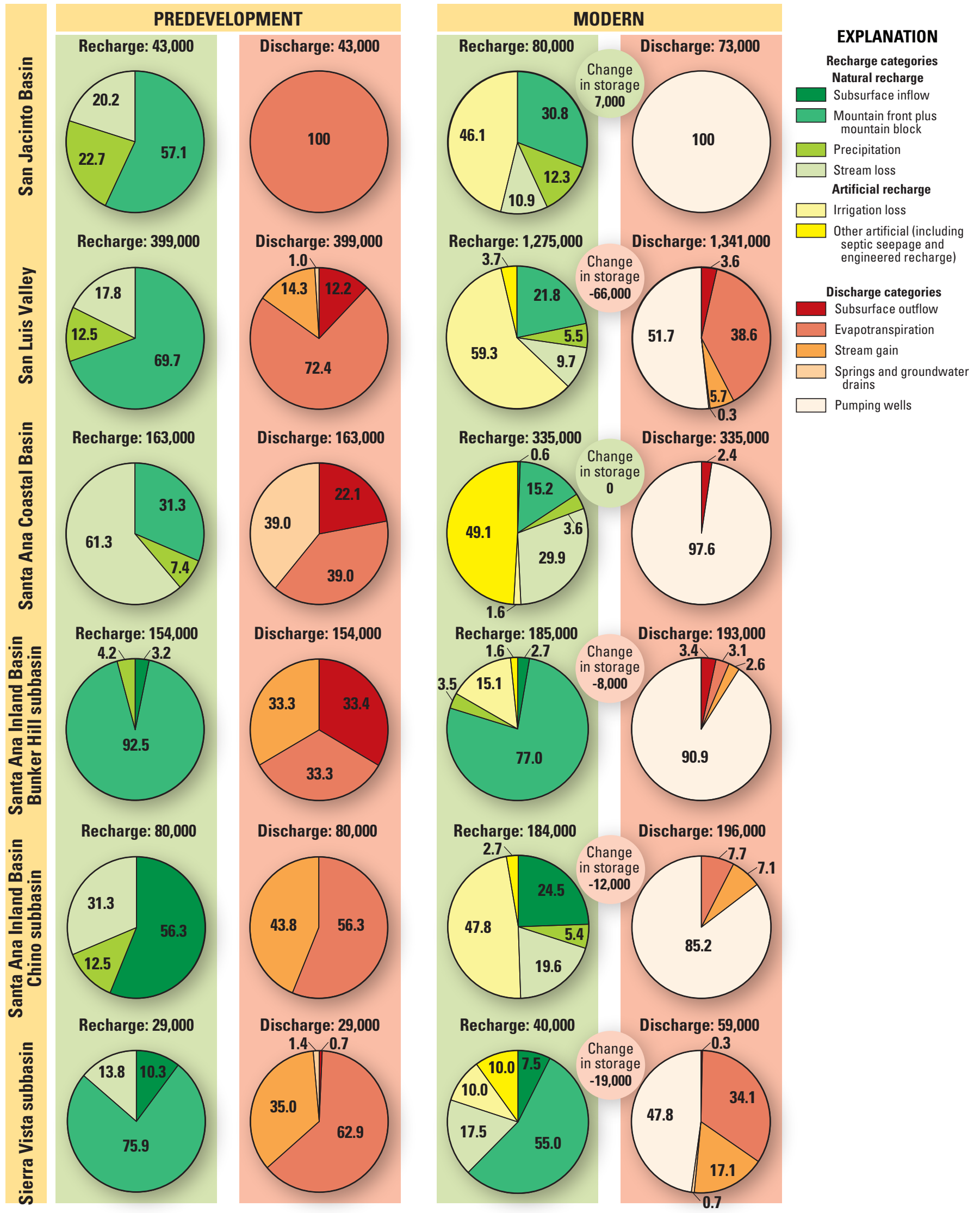

Figure 9. Pie diagrams showing categorization of recharge and discharge mechanisms for the 15 case-study basins in the Southwest Principal Aquifers study area under predevelopment and modern conditions.-Continued 


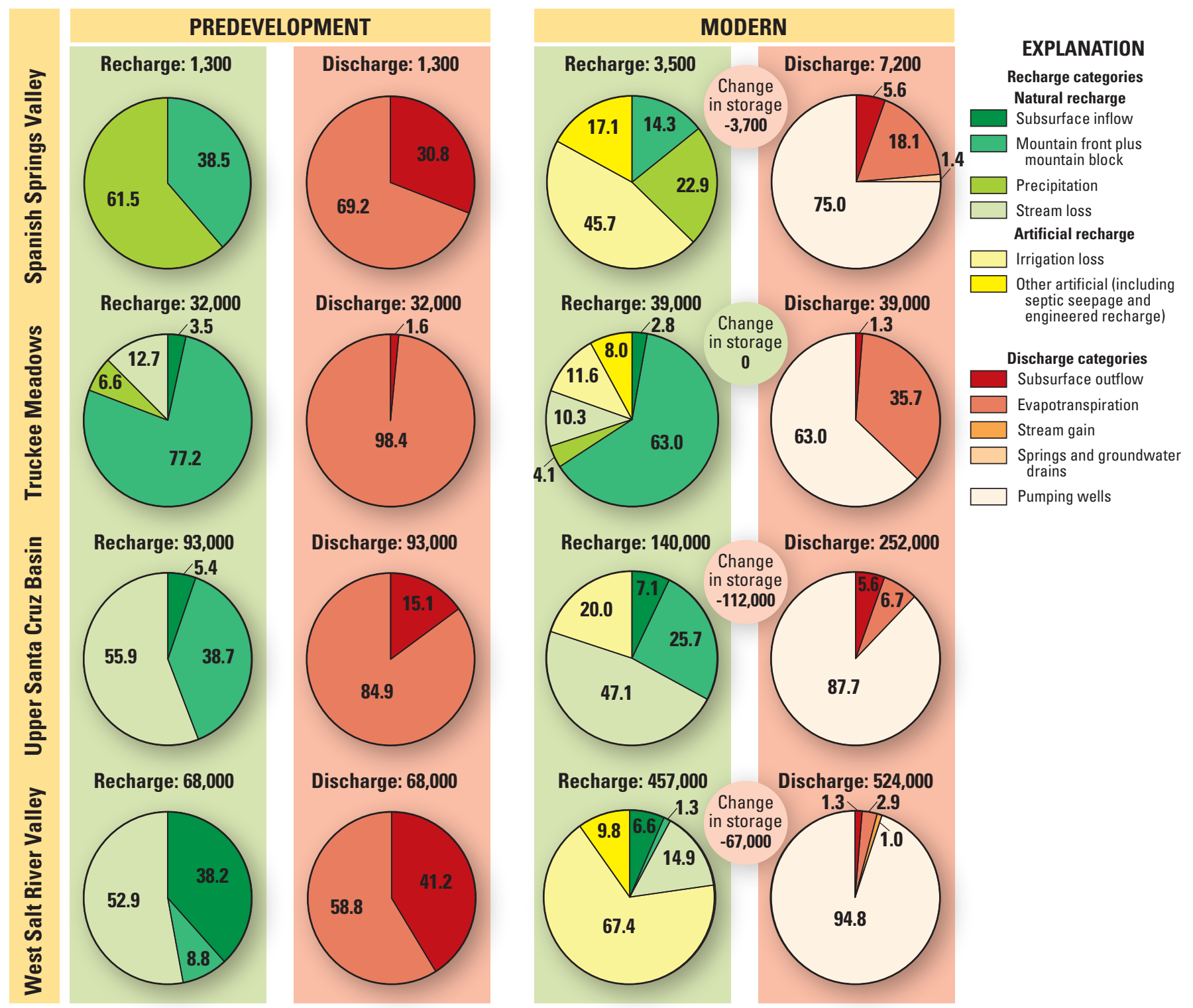

Figure 9. Pie diagrams showing categorization of recharge and discharge mechanisms for the 15 case-study basins in the Southwest Principal Aquifers study area under predevelopment and modern conditions.-Continued

\section{Mechanisms of Natural Discharge}

Natural mechanisms of discharge from basin-fill aquifers in the SWPA study area can be divided into two general groups: mechanisms that remove only water from the groundwater system and mechanisms that remove both water and solutes. Evapotranspiration, a process that includes evaporation of water from soil and transpiration of water by plants, removes only water and leaves solutes behind, resulting in an increase in the dissolved-solids concentration (including the concentration of selected individual contaminants) in the remaining groundwater through time. Evapotranspiration is the only natural mechanism for the discharge of groundwater from basins that are closed with respect to surface-water and groundwater drainage. Of the 15 SWPA case-study basins, only parts of the Central Valley, San Luis Valley, and San Jacinto Basin are essentially closed under most conditions. Discharge of groundwater to streams leaving the basin and (or) to springs and subsurface groundwater outflow are the other natural mechanisms of discharge from SWPA basin-fill aquifers. These mechanisms remove both water and solutes from the groundwater system. Under natural conditions, aquifers are assumed to have no change in storage on average, such that discharge from the groundwater system equals recharge to the system.

The 15 case-study basins of the SWPA study area differ with respect to the mechanism(s) dominating natural groundwater discharge (fig. 9), based on groundwater budgets derived from hydrologic studies or from groundwater flow models covering each basin in whole or in part. Under 


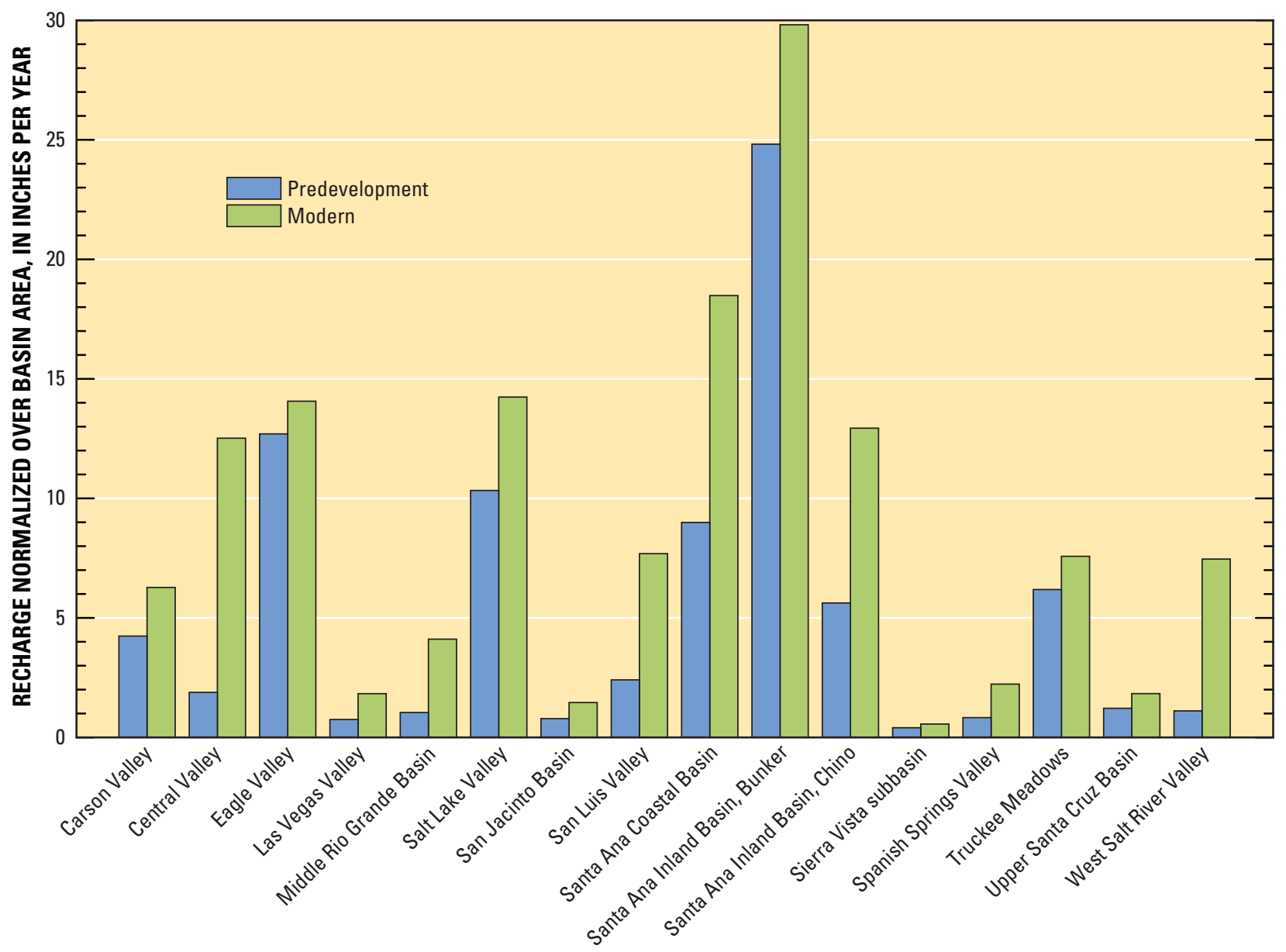

Figure 10. Normalized quantities of recharge to the 15 case-study basins in the Southwest Principal Aquifers study area.

predevelopment conditions, evapotranspiration was documented to account for more than half the discharge from all or part of 13 basins. Discharge to streams accounted for more than half the discharge from the Salt Lake Valley.

\section{Artificial Recharge}

Artificial recharge sources (defined for the purposes of this report as recharge sources that did not exist under predevelopment conditions) can substantially alter a groundwater system with respect to the location and quantity of recharge, resulting in changes to aquifer susceptibility. When human activity results in groundwater recharge where none was previously present, dissolved constituents that have built up in the unsaturated zone over time can be leached to the groundwater in large concentrations. Also, beneath areas where this new recharge is introduced, "young" water (defined in detail in the "Groundwater Ages and Residence Times" section) with the potential to carry human-related contaminants can reach parts of the aquifer where previously only water that recharged upgradient prior to human development was present. Because most artificial recharge sources are associated with agricultural or urban activities, they are generally more likely than natural recharge sources to contain human-related contaminants that can be transported to the aquifer at concentrations of concern. Changes in the quantity and distribution of recharge can also substantially alter hydraulic gradients, resulting in new flow directions and faster horizontal and (or) vertical movement of groundwater and any associated dissolved contaminants. In most of the 15 SWPA case-study basins, artificial recharge has become a substantial source of water to the basin-fill aquifer and has resulted in documented changes to the groundwater flow system (fig. 9).

\section{Sources and Mechanisms of Artificial Recharge}

Artificial recharge to basin-fill aquifers in the SWPA study area generally can be categorized according to its association with either agricultural or urban activities. Agricultural recharge sources are mainly related to the transport and application of water for crop irrigation. Urban recharge sources can be related to the transport of water for public supply, the application of water for urban irrigation, and (or) the disposal of wastewater. Urban recharge sources also can be related to the intentional enhancement of groundwater recharge and (or) underground storage of water for future supply; for the purposes of this report, any such source of recharge is considered "engineered" recharge. The sources of water that result 


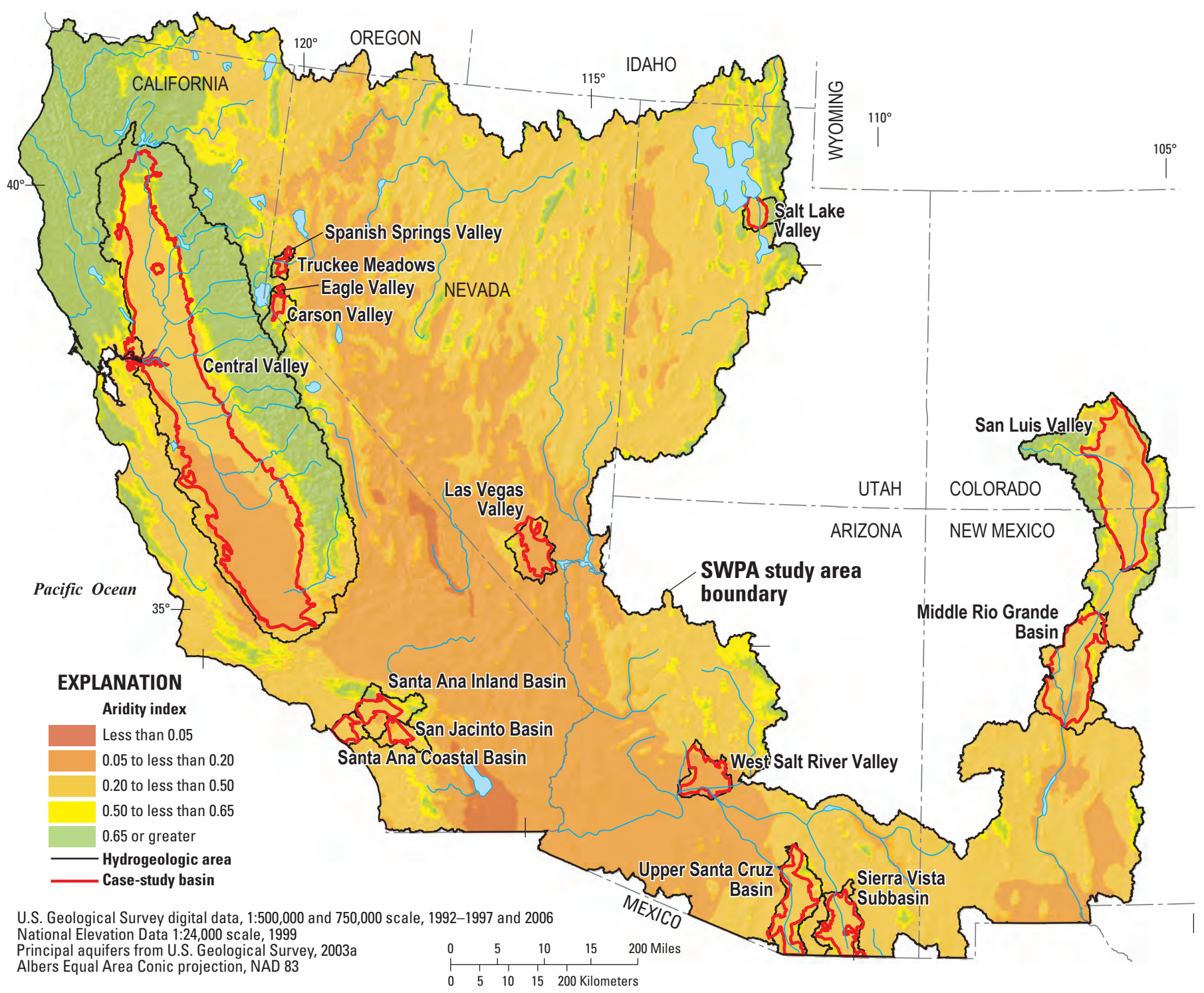

Figure 11. Values of the aridity index across the Southwest Principal Aquifers study area.

in artificial recharge to an aquifer through any of these various agricultural or urban processes can either be native to the individual basin of interest or imported to the basin from other areas. These sources of water can include native river water, imported river water, treated wastewater, captured stormwater runoff, and captured seasonal runoff. In many of the 15 casestudy basins, water other than native river water is used for irrigation and (or) public supply (table 5). Examples of sources of artificial recharge are shown in figure $8 \mathrm{~B}$.

Artificial recharge related to agricultural activities typically occurs through seepage of water from unlined irrigation canals and (or) seepage of excess irrigation water applied to fields. In areas where surface water is the primary source of irrigation water, typical consequences of irrigated agriculture are to spread out recharge of stream water across broad valley areas and increase the total quantity of stream water reaching the aquifer, such as has been documented for the Middle Rio Grande Basin. In areas where groundwater is a major component of irrigation water, its use increases recharge to and discharge from the groundwater system, with a net loss of groundwater in the aquifer because of evapotranspiration, such as has been documented for the San Luis Valley. Additional sources of artificial recharge in agricultural areas include seepage of water from ponds where irrigation water is stored prior to application and from waste ponds at feedlots. The water quality of artificial recharge resulting from agriculture can vary widely. For example, recharge from irrigation canals carrying diverted surface water can commonly be low in dissolved solids, nitrate, and manmade compounds. However, excess irrigation water and seepage from feedlot ponds commonly have elevated levels of dissolved solids, nitrate, and (or) manmade compounds such as pesticides. 
Table 5. Summary of the recent use of imported river water, treated wastewater, and captured runoff in the 15 case-study basins in the Southwest Principal Aquifers study area.

[Unless otherwise noted, references for the information presented are listed in corresponding basin chapters in Thiros and others (2010). Abbreviations: acre-ft/ yr, acre-feet per year]

\begin{tabular}{cll}
\hline Basin & Imported river water & Treated wastewater \\
\hline Carson Valley & None. & $\begin{array}{l}\text { Treated effluent from the Lake } \\
\text { Tahoe Basin since the late }\end{array}$ \\
& & 1960s and from Eagle Valley \\
& since 1988 is applied as & irrigation water and is stored in \\
& reservoirs and wetlands.
\end{tabular}

Central Valley Up to 7.5 million acre-ft/yr of surface water (mostly from the Sacramento Valley) can be transported southward from the Delta (California Department of Water Resources, 1993). Much of this imported water is used for agriculture in the San Joaquin Valley.

\section{Eagle Valley $\quad \begin{aligned} & \text { About } 1,800 \text { acre-ft/yr (based on average } \\ & 1995-1998 \text { conditons) of Carson River water } \\ & \text { from induction wells in the Dayton Valley } \\ & \text { hydrographic area is used for Carson City } \\ & \text { municipal supply. }\end{aligned}$}

Las Vegas Valley Artificial recharge of treated Colorado River water through injection wells occurs in the northwestern and central parts of the valley (about 15,900 acre-ft was artificially recharged in 2005). Unconsumed landscape irrigation water piped from Lake Mead recharges the shallow aquifer, estimated to be about 50,000 acre-ft in 1987.
No known use of treated wastewater.
Recharge from irrigation of golf courses with treated effluent is about 600 acre-ft/yr.
Water captured in reservoirs built on streams feeding the valley is used for irrigation and recharges the aquifer. The quantity of captured runoff varies widely from year to year, but on average is estimated to enhance aquifer recharge by about 2,000,000 acre-ft/yr. Dry wells are used to dispose of storm runoff locally.

About 1,100 acre-ft/yr imported from Marlette and Hobart Lakes and small amounts (700 acre-ft total from 1991-1997) recharged through infiltration beds in Vicee Canyon are used for Carson City municipal supply. Values based on average 1995-1998 conditons.

About 16,200 acre-ft of treated

No known plans to use captured runoff. wastewater effluent was reclaimed and used to irrigate greenspace such as parks and golf courses in 2005 .

\section{Middle Rio Grande About 110,000 acre-ft/yr of water is diverted from the San Juan River Basin to the Rio Grande Basin. Some of this imported water is consumed before reaching the Middle Rio Grande Basin, where the City of Albuquerque owns 48,200 acre-ft/yr that is diverted for drinking-water supply. Future City plans for this water include underground storage.}

Salt Lake Valley An average of about 111,000 acre-ft/yr was imported to the valley for public supply from surface-water sources in the Weber and Duchesne River Basins for 1997-2003.
Treated industrial and municipal wastewater is used for urban turf irrigation in Albuquerque; full capacity is estimated at 6,700 acre-ft/yr (City of Albuquerque Public Works Department, 1997).

No known plans to use captured runoff.

No known use of treated wastewater.
Artificial recharge of treated surface water through injection wells in the southeast part of the valley. Reported recharge averaged about 400 acre-ft/ yr in 2000-09 (Utah Division of Water Rights, written commun., January 5, 2010).

\begin{tabular}{|c|c|c|}
\hline San Jacinto & $\begin{array}{l}\text { Aqueducts for State Project water from northern } \\
\text { California and for Colorado River water pass } \\
\text { through the San Jacinto Basin. Both of these } \\
\text { imported water sources have been utilized } \\
\text { in the region for irrigation and municipal } \\
\text { supply. About } 84,000 \text { acre-ft was imported in } \\
2005 \text {, mostly for public supply. }\end{array}$ & $\begin{array}{l}\text { Recharge occurs through seepage } \\
\text { at retention basins, spreading } \\
\text { basins, and percolation ponds } \\
\text { filled with treated wastewater. } \\
\text { About } 16,600 \text { acre-ft/yr is es- } \\
\text { timated to recharge the eastern } \\
\text { subbasins and about } 20,300 \\
\text { acre-ft/yr the western subbasins } \\
\text { from unconsumed irrigation } \\
\text { and other artificial sources } \\
\text { including treated wastewater. }\end{array}$ \\
\hline
\end{tabular}

San Luis Valley None, but groundwater is pumped from the San
Luis closed basin and delivered to the Rio
Grande to help meet compact obligations (average 22,560 acre-ft/yr for 1986-97).
Recharge and retention basins are estimated to capture about 1,000-3,000 acre-ft/yr of excess runoff.
Unquantified capture of irrigation water occurs in recharge pits in agricultural areas. 
Table 5. Summary of the recent use of imported river water, treated wastewater, and captured runoff in the 15 case-study basins in the Southwest Principal Aquifers study area.-Continued

\begin{tabular}{|c|c|c|c|}
\hline Basin & Imported river water & Treated wastewater & Captured runoff \\
\hline Santa Ana Coastal & $\begin{array}{l}\text { Orange County Water District began importing } \\
\text { water from the Colorado River in the early } \\
1950 \text { s; it was the dominant source of ground- } \\
\text { water recharge from about } 1957 \text { to } 1971 \text {. } \\
\text { Water imported from northern California } \\
\text { also has been used to recharge the aquifer. } \\
\text { Artificial recharge of imported water during } \\
1986-2005 \text { ranged from about } 10,000 \text { to } \\
80,000 \text { acre-ft/yr. }\end{array}$ & $\begin{array}{l}\text { Estimated base flow in the Santa } \\
\text { Ana River below Prado Dam } \\
\text { has increased from about } \\
40,000 \text { acre-ft in } 1970 \text { to } \\
\text { about } 155,000 \text { acre-ft in } 2001 \text {, } \\
\text { primarily due to increases in } \\
\text { treated wastewater discharge } \\
\text { in the upgradient Inland } \\
\text { Basin. Much of this base flow } \\
\text { recharges the Coastal Basin } \\
\text { aquifer. Within the basin, about } \\
42,000 \text { acre-ft/yr of water has } \\
\text { been treated for infiltration at a } \\
\text { recharge facility near the Santa } \\
\text { Ana River since } 2008 \text {. }\end{array}$ & $\begin{array}{l}\text { Annual recharge to the aquifer from captured Santa } \\
\text { Ana River stormflow is estimated to average } \\
\text { about } 60,000 \text { acre-ft. }\end{array}$ \\
\hline Santa Ana Inland & $\begin{array}{l}\text { Total water imports from northern California } \\
\text { to the Bunker Hill subbasin averaged about } \\
10,000 \text { acre-ft/yr for } 1972-98 \text {, with an aver- } \\
\text { age of } 6,000 \text { acre-ft/yr artificially recharged. } \\
\text { Water imported from northern California for } \\
\text { direct use in the Chino subbasin increased } \\
\text { from about } 11,000 \text { acre-ft in } 1980 \text { to about } \\
55,000 \text { acre-ft in } 2005 \text { (Inland Empire Utili- } \\
\text { ties Agency, 2005). }\end{array}$ & $\begin{array}{l}\text { No known use of treated wastewa- } \\
\text { ter in the Bunker Hill subbasin. } \\
\text { Infiltration of imported water } \\
\text { and treated municipal wastewa- } \\
\text { ter effluent at artificial recharge } \\
\text { facilities in the Chino subbasin } \\
\text { averaged about } 5,000 \text { acre-ft/yr } \\
\text { for } 1960-2006 \text {. }\end{array}$ & $\begin{array}{l}\text { Most of the annual recharge to the Bunker Hill } \\
\text { subbasin is from the infiltration of mountain } \\
\text { runoff (136,500 acre-ft). Much of the runoff is } \\
\text { diverted into stormwater-detention basins in or } \\
\text { adjacent to stream channels for groundwater } \\
\text { recharge. Recharge from captured stormwater } \\
\text { runoff in the Chino subbasin is estimated to have } \\
\text { averaged about } 9,000 \text { acre-ft/yr for } 1960-2006 \text {. }\end{array}$ \\
\hline $\begin{array}{l}\text { Sierra Vista Sub- } \\
\text { basin }\end{array}$ & None. & $\begin{array}{l}\text { Some treated wastewater from } \\
\text { Sierra Vista is artificially } \\
\text { recharged, and some treated } \\
\text { wastewater from Benson is ap- } \\
\text { plied to landscape irrigation. }\end{array}$ & $\begin{array}{l}\text { Unquantified capture of stormwater runoff occurs } \\
\text { in recharge or detention pits within urban areas. }\end{array}$ \\
\hline $\begin{array}{l}\text { Spanish Springs } \\
\text { Valley }\end{array}$ & $\begin{array}{l}\text { Transmission losses from the Orr Ditch and } \\
\text { excess irrigation water applied to crops } \\
\text { recharged about } 1,450 \text { acre-ft of Truckee } \\
\text { River water to shallow parts of the basin-fill } \\
\text { aquifer in } 1994 \text {. }\end{array}$ & $\begin{array}{l}\text { No known use of treated waste- } \\
\text { water. }\end{array}$ & No known plans to use captured runoff. \\
\hline $\begin{array}{l}\text { West Salt River } \\
\text { Valley }\end{array}$ & $\begin{array}{l}\text { Imported Colorado River water, and surface } \\
\text { waters originating outside West Salt River } \\
\text { Valley in the upper Agua Fria, Salt, and } \\
\text { Verde River Basins diverted for municipal } \\
\text { uses as well as irrigation of urban landscap- } \\
\text { ing and croplands. }\end{array}$ & $\begin{array}{l}\text { Much of the treated wastewater } \\
\text { from two treatment plants is } \\
\text { used to irrigate non-edible } \\
\text { crops in the western part of } \\
\text { the basin. Treated wastewater } \\
\text { from several plants is released } \\
\text { for intentional recharge } \\
\text { through streambeds or artificial } \\
\text { recharge facilities. }\end{array}$ & $\begin{array}{l}\text { Dry wells are used to capture urban stormwater } \\
\text { runoff. Irrigation runoff is captured by canals and } \\
\text { redistributed for subsequent irrigation. }\end{array}$ \\
\hline
\end{tabular}


Artificial recharge related to urban activities can occur through a wide variety of mechanisms. Similar to agricultural irrigation, the transport and application of water for urban irrigation (of lawns, parks, and golf courses, for example) allows for artificial recharge across broad areas through seepage from leaky distribution pipes and infiltration of excess irrigation water. Water intended for public supply also seeps from leaky distribution pipes, and the fraction that is not consumed by households is subject to seepage from leaky sewer lines. In unsewered areas, septic fields can be a substantial source of artificial recharge (septic fields contribute 17 percent of total modern recharge in Spanish Springs Valley, for example). In some basins in the SWPA study area, treated wastewater is used for irrigation (for example, Eagle Valley, Las Vegas Valley, and Upper Santa Cruz Basin) or is diverted to engineered recharge facilities that include percolation ponds or injection wells (for example, see the text box, "Engineered Recharge in the Santa Ana Coastal Basin"). Storm-detention basins commonly have been constructed to capture runoff from mountains or impervious urban surfaces; at least part of this captured water typically is intended for aquifer recharge. Multiple dry wells (generally pits, trenches, or holes filled with high-permeability material and lined with a filter) are used in some urban areas such as Modesto, California (Jurgens and others, 2008), and Phoenix, Arizona, to reduce urban runoff and route water to the subsurface. In a few basins such as the Santa Ana Inland Basin and Truckee Meadows, streams are diverted to engineered recharge facilities (such as spreading basins or injection wells) for the recharge of native and (or) imported surface water. Even when not diverted to such facilities, addition of imported surface water to natural stream channels can enhance aquifer recharge by raising the stage in the channel upstream from locations where the water is diverted for use, resulting in greater infiltration.

As with artificial recharge related to agricultural activities, artificial recharge related to urban activities can vary widely in water quality. For example, recharge from basins capturing mountain runoff might have very low concentrations of dissolved solids, nitrate, and manmade compounds. Seepage from water distribution lines might have low levels of most potential contaminants but might contain chlorination byproducts, such as trihalomethanes. Seepage from sewer lines or septic fields might be elevated in dissolved solids and nitrate and might contain household chemicals. Infiltrating urban runoff might contain pesticides (from landscaping) and petroleum products (from paved areas). Therefore, the areal distribution of - and quantities of water from - these various sources of artificial recharge can have a substantial influence on groundwater quality.

\section{Quantities of Artificial Recharge}

The quantities of artificial recharge to the 15 SWPA casestudy basins from agricultural and urban sources vary widely. The quantity of artificial recharge from irrigated agriculture and its associated infrastructure depends not only on the areal extent of crops and unlined canals but also on irrigation methods (flood versus sprinkler) and their efficiency. In addition, the degree to which natural river stage is altered by irrigation practices (diversions, reservoir releases, and additions of imported water) in an individual basin can have an effect on recharge quantity. The quantity of artificial recharge from urban sources also depends on a variety of factors, including the extent of sewered versus unsewered urban areas, the methods used to dispose of wastewater, and the degree to which engineered recharge facilities are utilized.

On the basis of groundwater budgets for the 15 case-study basins, artificial recharge has become a major source - and, in several cases, the dominant source - of groundwater recharge to most basins under modern conditions. Combined irrigation losses resulting from seepage from irrigation canals, irrigated agricultural fields, and urban turf areas currently provide at least half of the recharge to the basin-fill aquifers in the Central Valley, San Luis Valley, and West Salt River Valley (fig. 9). The quantity of water recharged through irrigation losses in these three basins ranges from about 308,000 acre- $\mathrm{ft} / \mathrm{yr}$ in the West Salt River Valley to about 9.2 million acre-ft/yr in the Central Valley, or (on the basis of recharge per unit area) about $4.6 \mathrm{in} /$ $\mathrm{yr}$ in the San Luis Valley to about $8.7 \mathrm{in} / \mathrm{yr}$ in the Central Valley. Although irrigation losses do not dominate recharge in the San Jacinto Basin as a whole, they do account for more than half the recharge to the western subbasins. Irrigation losses contribute 15 percent or less of the recharge to the basin-fill aquifers in the Eagle Valley, Santa Ana Coastal Basin, Sierra Vista subbasin, and Truckee Meadows.

For most of the 15 case-study basins, other artificial recharge sources -including septic-tank seepage, water-system leakage, recharge through impoundments and spreading facilities, and recharge through injection wells - contribute substantially less water to basin-fill aquifers than irrigation loss does (fig. 9). The major exception is the Santa Ana Coastal Basin, where nearly half (about 165,000 acre-ft/yr or $9.1 \mathrm{in} / \mathrm{yr}$ ) of all groundwater recharge comes from engineered recharge, primarily through spreading facilities. Urban sources of artificial recharge contribute about 10 percent or more of recharge in Las Vegas Valley (through injection wells), the Sierra Vista subbasin (through effluent recharge and turf facilities and septic-tank seepage), Spanish Springs Valley (through septictank seepage), and West Salt River Valley (through recharge facilities and artificial lakes). The Santa Ana Coastal Basin, Las Vegas Valley, and West Salt River Valley all have populations exceeding one million, making the intentional use of artificial recharge to enhance the availability of groundwater for public supplies an attractive and cost-effective water-management option. The quantity of water that is artificially recharged can change seasonally and annually as a result of water demand and the availability of supplies.

In all 15 case-study basins, the addition of artificial recharge has resulted in at least a 10 percent increase in total recharge to the basin-fill aquifer between predevelopment and modern conditions (fig. 10). The magnitudes of changes that have taken place in recharge between predevelopment and modern conditions in relation to changes in land use are 


\section{Engineered Recharge in the Santa Ana Coastal Basin}

Artificial recharge to the groundwater system and pumping from wells has accelerated the movement of water and the transport of dissolved constituents through much of the Santa Ana Coastal Basin basin-fill aquifer. The aquifer provides about 70 percent of the water needs for more than 2.5 million people in the Coastal Basin with more than 200 large-capacity public-supply wells accounting for most of the groundwater discharge (about 333,000 acre-ft/yr) from the basin (Woodside and Westropp, 2009). The Orange County Water District actively manages the Coastal Basin aquifer to meet both water quantity and quality goals.

Groundwater recharge from natural streamflow infiltration and at engineered recharge facilities is essential to balance groundwater pumping from the basin for public supply.

The Santa Ana River begins in the San Bernardino Mountains and flows west more than $100 \mathrm{mi}$ to the Pacific Ocean. Almost all of the flow in the river is diverted after it enters the Coastal Basin for recharge at engineered recharge facilities designed to replenish the basin-fill aquifer. Currently, flow in the Santa Ana River to the basin consists predominantly of perennial base flow that is mostly treated wastewater from the upstream Santa Ana Inland Basin (Mendez and Belitz, 2002) and intermittent stormflow that includes runoff from urban and agricultural land. The river channel and recharge basins provide most of the recharge to the aquifer, about 250,000 acre-ft/yr.

The Orange County Water District began largescale recharge to the Coastal Basin with water imported from the Colorado River in the early 1950s and it was the dominant source of recharge from about 1957 to 1971 (Wildermuth Environmental, Inc., 2000). The imported water historically had higher concentrations of dissolved solids (about $700 \mathrm{mg} / \mathrm{L}$ ) than the native groundwater (generally less than about 500 $\mathrm{mg} / \mathrm{L}$ ) and, as a consequence, concentrations of dissolved solids in groundwater began to increase (Herndon and others, 1997). Imported water from the Colorado River and northern California is used less extensively now for artificial recharge because of water-quality and availability issues.
Treated wastewater, processed using microfiltration, reverse osmosis, and advanced oxidation, began recharging the Coastal Basin aquifer in 2008. About 37,000 acre-ft of treated water with low concentrations of dissolved solids was recharged in 2008 at spreading basins near the Santa Ana River (Woodside and Westropp, 2009).

Artificial recharge and groundwater pumping have resulted in very large vertical and lateral rates of groundwater flow through the basin-fill aquifer. Tritium-helium-3 apparent ages of water sampled from 300-500 ft below land surface along a flow path originating at recharge basins near the Santa Ana River indicated that groundwater less than five years old had traveled more than one mile from the recharge basins (Davisson and others, 2004). Groundwater ages progressively increased to over 20 years old approximately 5-6 mi west of the recharge basins (Davisson and others, 2004). Vertically, groundwater was less than one year old more than $500 \mathrm{ft}$ below the recharge basins (Davisson and others, 2004). The water can move quickly into the aquifer because thin unsaturated zones underlie the recharge basins. Water-quality data showed that water entering the ground at the recharge facilities extended over $11 \mathrm{mi}$ into the aquifer along a studied flow path (Dawson and others, 2003).

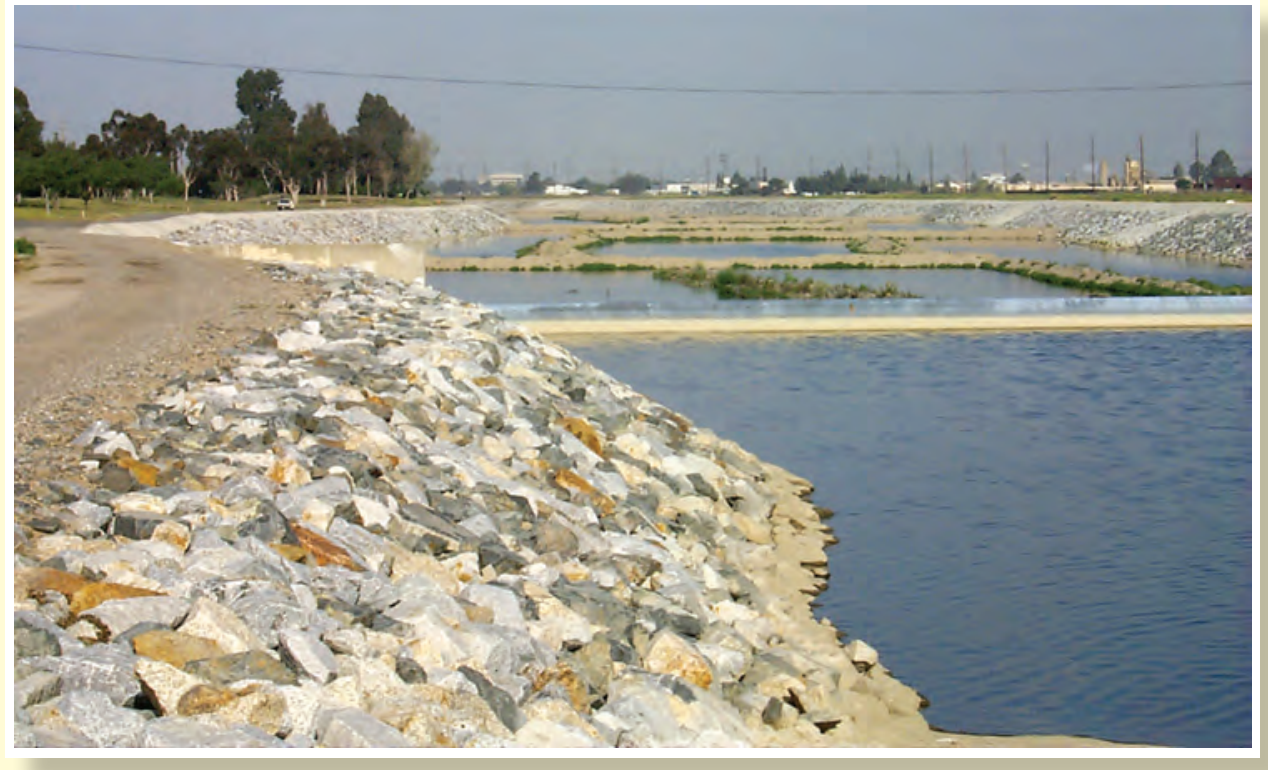

Water managers utilize the flow of the Santa Ana River for recharging the groundwater basin. An inflatable rubber dam across the Santa Ana River impounds water to facilitate diversion into recharge ponds (photograph by Carmen Burton, U.S. Geological Survey). 
demonstrated in figure 12. In effect, this figure illustrates how much the potential driving force for contaminant transport to the aquifer (groundwater recharge) has increased along with the availability of several types of potential contaminants (represented by land use). For three basins or major subbasinsEagle Valley, the Bunker Hill subbasin of the Santa Ana Inland Basin, and Truckee Meadows - the increase in total recharge has been 25 percent or less, despite agricultural plus urban land use covering at least 60 percent of the area in each basin. Therefore, although the availability of potential contaminants appears to have increased over large areas of these basins, the driving force needed to transport contaminants to the aquifer has not increased substantially relative to other basins.

For eight basins or major subbasins - Central Valley, Las Vegas Valley, Middle Rio Grande Basin, San Luis Valley, Santa Ana Coastal Basin, the Chino subbasin of the Santa Ana Inland Basin, Spanish Springs Valley, and West Salt River Valley-groundwater recharge has at least doubled (figs. 10 and 12). In the Central Valley and West Salt River Valley in particular, groundwater recharge is currently more than five times greater than it was under predevelopment conditions, with sources of artificial recharge contributing about 11.3 million acre-ft/yr (10.6 in/yr) and 389,000 acre-ft/yr (7.0 in/yr), respectively. In most of the basins where recharge has at least doubled, about 30 percent or more (and as much as 95 percent) of the land use in the basin is agricultural or urban (fig. 12), indicating the likely presence of potential contaminant sources across relatively broad areas. For the Middle Rio Grande Basin (agricultural and urban land use totaling 12 percent), San Luis Valley (agricultural and urban land use totaling 17 percent), and Spanish Springs Valley (agricultural and urban land use totaling 28 percent), the dramatic increase in recharge has been accompanied by smaller areas of development and, therefore, a smaller increase in the availability of contaminants associated with human activities.

\section{Time Scale of Development}

The time scale over which development (either agricultural or urban) has occurred can be reflected in present-day groundwater quality. This time-scale factor relates both to when artificial recharge began to have a major impact on the groundwater flow system (which is indicative of the amount of water currently in the aquifer that originated as artificial recharge) and to when human-related contaminants began to be available for transport to the aquifer. Current groundwater quality in basins where irrigated agriculture and associated infrastructure are present and had already progressed

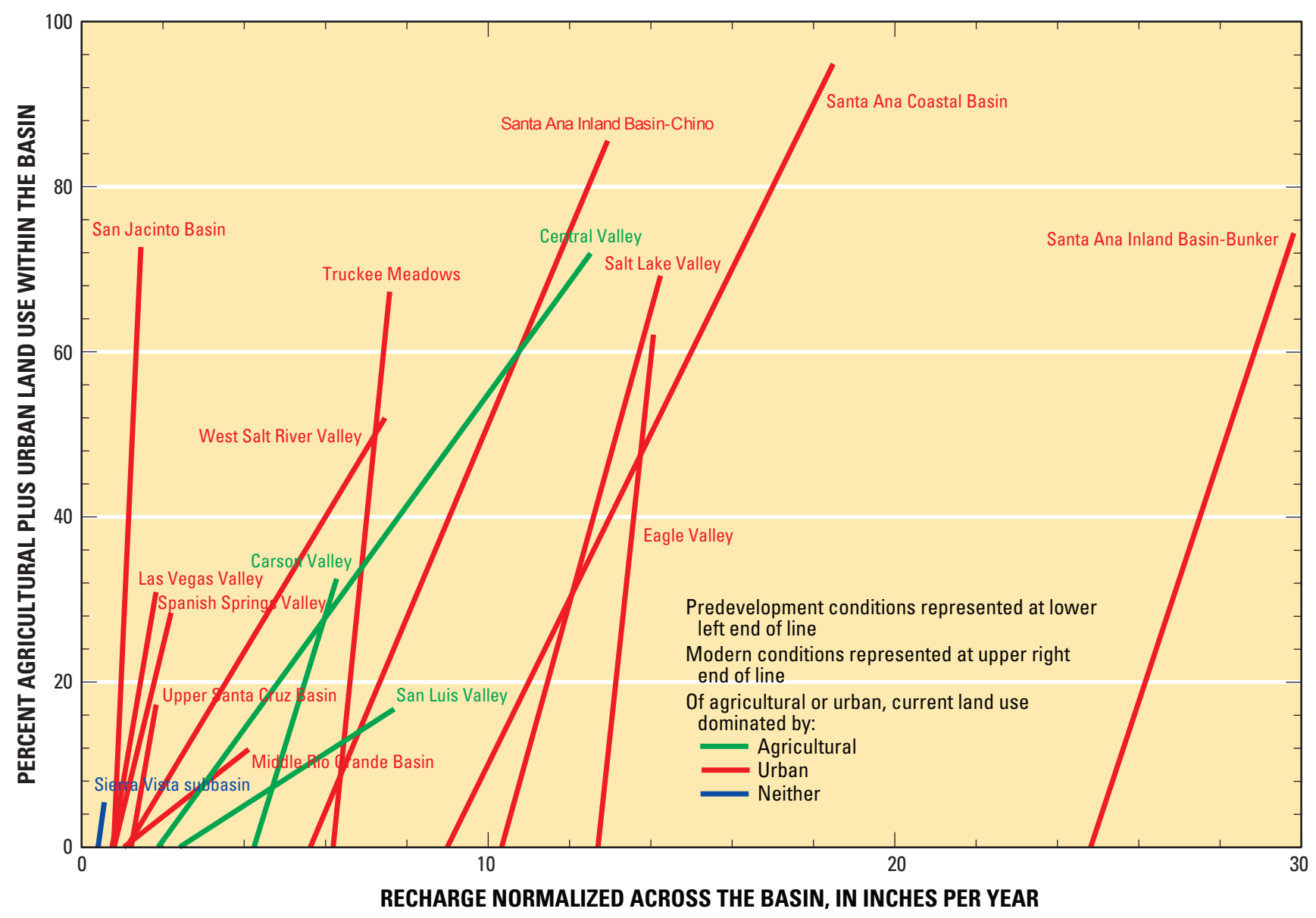

Figure 12. Relation between land use and recharge for predevelopment and modern conditions in the 15 case-study basins in the Southwest Principal Aquifers study area. 
substantially toward their full state of development by the mid to late 1800 s (which includes most of the 15 case-study basins where appreciable irrigated agriculture is present) is likely to show evidence of irrigation seepage. Such evidence might include elevated dissolved solids, nutrients, and (or) pesticide concentrations in some areas relative to background conditions. The exact timing of agricultural development has probably influenced how deep and (or) how far downgradient in the aquifer these water-quality effects can be observed. Similarly, in basins where rapid urbanization took place by the 1940s-50s (which includes most case-study basins with substantial urban land use), water-quality alterations associated with urban recharge- - such as elevated concentrations of dissolved solids, nutrients, pesticides, and (or) VOCs - that presently can be observed are likely to be more widespread and to have affected greater depths than in basins where urbanization was not widespread until the 1970s (such as the Spanish Springs Valley). Generally, urban development has occurred in areas that were previously agricultural, resulting in water-quality effects at the same location from both types of land use, just on different time scales. In general, water-quality changes resulting from either agricultural or urban recharge/ contaminant sources also are likely to be more widespread and deeper at present in basins where intense groundwater pumping has been sustained for a long enough time to substantially alter horizontal and vertical flow gradients.

\section{Groundwater Ages and Residence Times}

The term "groundwater age" generally refers to the number of years that have elapsed since a water sample was isolated from the atmosphere - that is, the time since recharge (Plummer and Busenberg, 2006). Estimates of groundwater age are very useful in evaluating the susceptibility of an aquifer to contamination with human-related and (or) natural contaminants. The presence of common tracers of "young" (post-1940s) recharge - tritium, chlorofluorocarbons, and (or) sulfur hexafluoride - provide an indication that some fraction of groundwater likely recharged during a time when humanrelated contaminants might have been present and available for transport to the aquifer. Groundwater that does not have detectable concentrations of any of these tracers generally is considered unlikely to have been substantially affected by contamination resulting from human activities. Some tracers (including carbon-14) allow age estimation for groundwater that recharged from about 1,000 years to as much as 40,000 years before present. Water that has been in the ground for thousands of years generally is considered more likely to have acquired elevated concentrations of natural contaminants as a result of long contact times with geologic materials and the increased possibility of having encountered variable oxidationreduction (redox) conditions. Many groundwater samplesespecially those collected from wells with long open intervals - are actually mixtures of young and old groundwaters. Estimation of the distribution of groundwater ages that such a sample represents requires detailed mixing calculations using multiple tracers and (or) groundwater flow modeling.

Because age-dating techniques were developed relatively recently and are rather expensive, most of the 15 SWPA casestudy basins do not yet have age-dating data for many wells or for more than one or two tracers. A couple of exceptions are the Middle Rio Grande Basin (see the text box, "Groundwater Ages in the Middle Rio Grande Basin") and the Salt Lake Valley. In the Salt Lake Valley, multiple tracers of young groundwater measured in public-supply wells allowed estimation by Thiros and Manning (2004) of groundwater ages of less than 3 to more than 50 years. Data from several wells indicated that a large component of the groundwater had recharged prior to 1952; however, carbon-14 data from several wells without substantial quantities of young tracers indicated groundwater ages on the order of thousands of years. Detections of manmade compounds and elevated nitrate concentrations were well correlated with interpreted ages, indicating that wells with a greater component of young water were generally more vulnerable to human-related contamination.

Descriptions of the available age-dating information for all SWPA case-study basins are included in table 6 . In basins where samples for tracers of young water are known to have been collected, these tracers have been detected in most groundwater samples from the shallow part of the aquifer not used for drinking (typically up to about 30-50 ft below the water table in most basins). Young tracers have been detected somewhat less commonly in samples from the intermediate part of the aquifer generally used for domestic water supply (typically between about 30-50 ft and 100-200 ft below the water table). Finally, young tracers have been detected least frequently, but at least occasionally, in samples from the deep part of the aquifer generally used for public supply (typically more than about 100-200 ft below the water table). Data from the San Jacinto, Santa Ana Inland, and Santa Ana Coastal case-study basins in California and from the Sierra Vista subbasin, Upper Santa Cruz Basin, and West Salt River Valley in Arizona indicate that wells where tracers of young water (often tritium) are found commonly are associated with higher detection frequencies of manmade compounds. Dating of older groundwater using carbon-14 has been less common among the case-study basins. However, in the basins where radiocarbon dating has been conducted (the Middle Rio Grande Basin, Salt Lake Valley, San Luis Valley, and Sierra Vista subbasin), estimated groundwater ages exceeding 10,000 years for some wells suggest the potential for elevated concentrations of selected natural contaminants to be present. In the Middle Rio Grande Basin, for example, higher arsenic concentrations commonly were associated with areas where older, deeper groundwater was moving upward into shallower parts of the aquifer.

Groundwater residence time refers to the amount of time that elapses between water particles recharging to and discharging from the aquifer. Knowledge of residence time gives a sense of how long it takes dissolved contaminants to move 


\section{Groundwater Ages in the Middle Rio Grande Basin}

In the Middle Rio Grande Basin, New Mexico, Plummer and others (2004) estimated the age of groundwater across the basin using samples collected from nearly 300 wells of various types and depths. The samples were analyzed for multiple tracers of young water (tritium, chlorofluorocarbons, and sulfur hexafluoride) and for one tracer of old water (carbon-14). Based on the carbon-14 data, groundwater throughout most of the basin was found to have recharged thousands of years ago (see figure), implying generally low aquifer vulnerability to modern, human-related contaminants. Much of the groundwater currently within the aquifer actually was estimated to be at least twenty thousand years old, implying that it recharged during the last glacial maximum, when conditions in the Southwest were considerably cooler and wetter. The very long times required for groundwater to move from recharge to discharge areas indicate a generally low recharge rate relative to the large volume of the basin-fill aquifer.

Tracers of young water were detected primarily near known areas of aquifer recharge-particularly along the mountain fronts, near arroyos, and in the Rio Grande inner valley where depths to water are generally less than about 30 feet. However, some detections of young tracers were from water-table wells beneath upland areas where recharge is not thought to have occurred in substantial quantities under natural

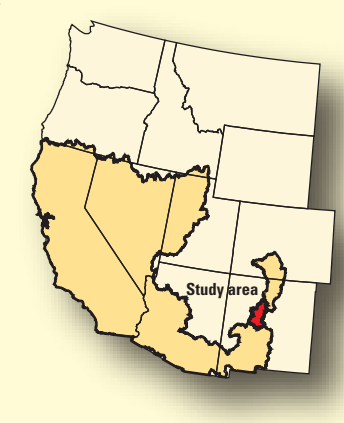

EXPLANATION

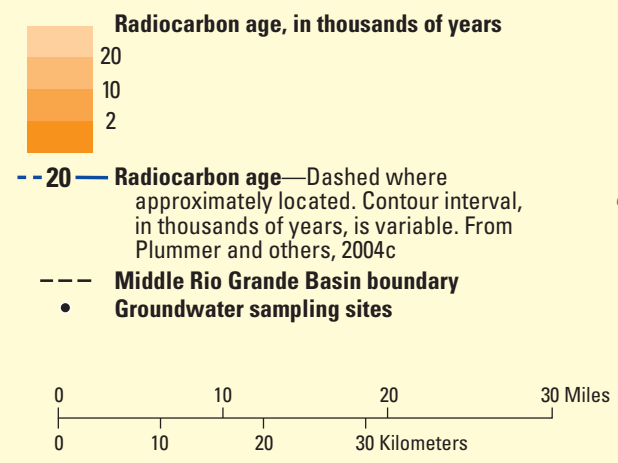

Base compiled from U.S. Geological Survey digital data, 1:100,00 scale, 1977, 1978 City of Albuquerque digital data, 1994

Albers Equal-Area Conic Projection, standard parallels $29^{\circ} 30^{\prime}, 45^{\circ} 30^{\prime}$, central meridian $106^{\circ} 40^{\prime}$

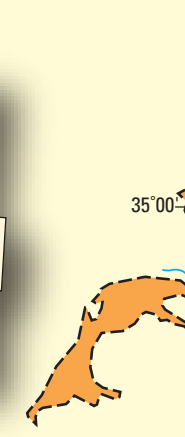

conditions. Detections of young tracers in these areas could indicate the presence of artificial recharge sources that have not been well characterized, and consequently, might suggest higher vulnerability to contamination than previously believed. The young water reaching the aquifer in these areas that previously lacked recharge is being introduced to a system with generally very old water and long flow paths. As a result, any associated contaminants will likely reside in the aquifer for long times before reaching the discharge

$$
\text { area. }
$$

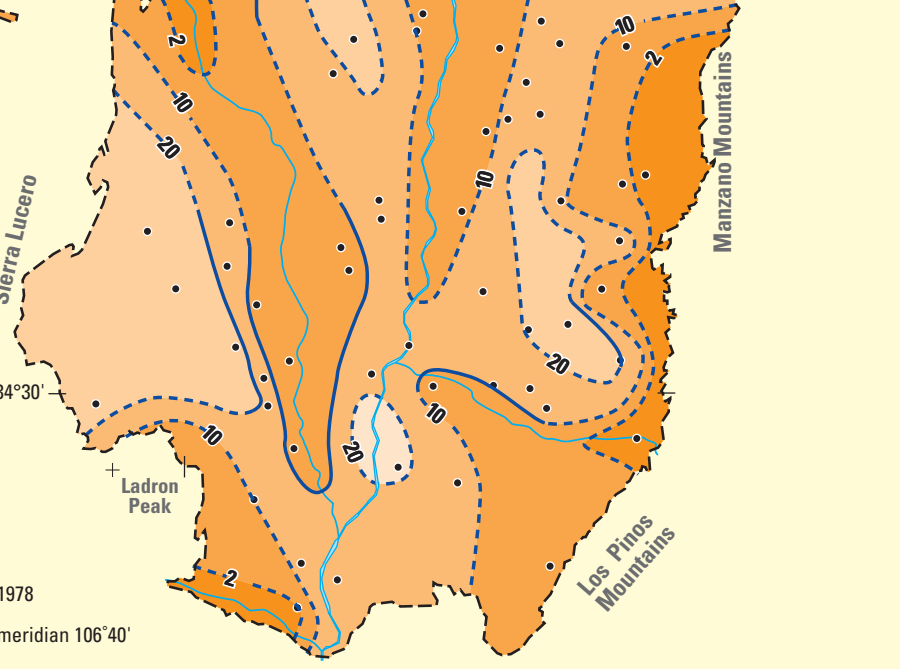




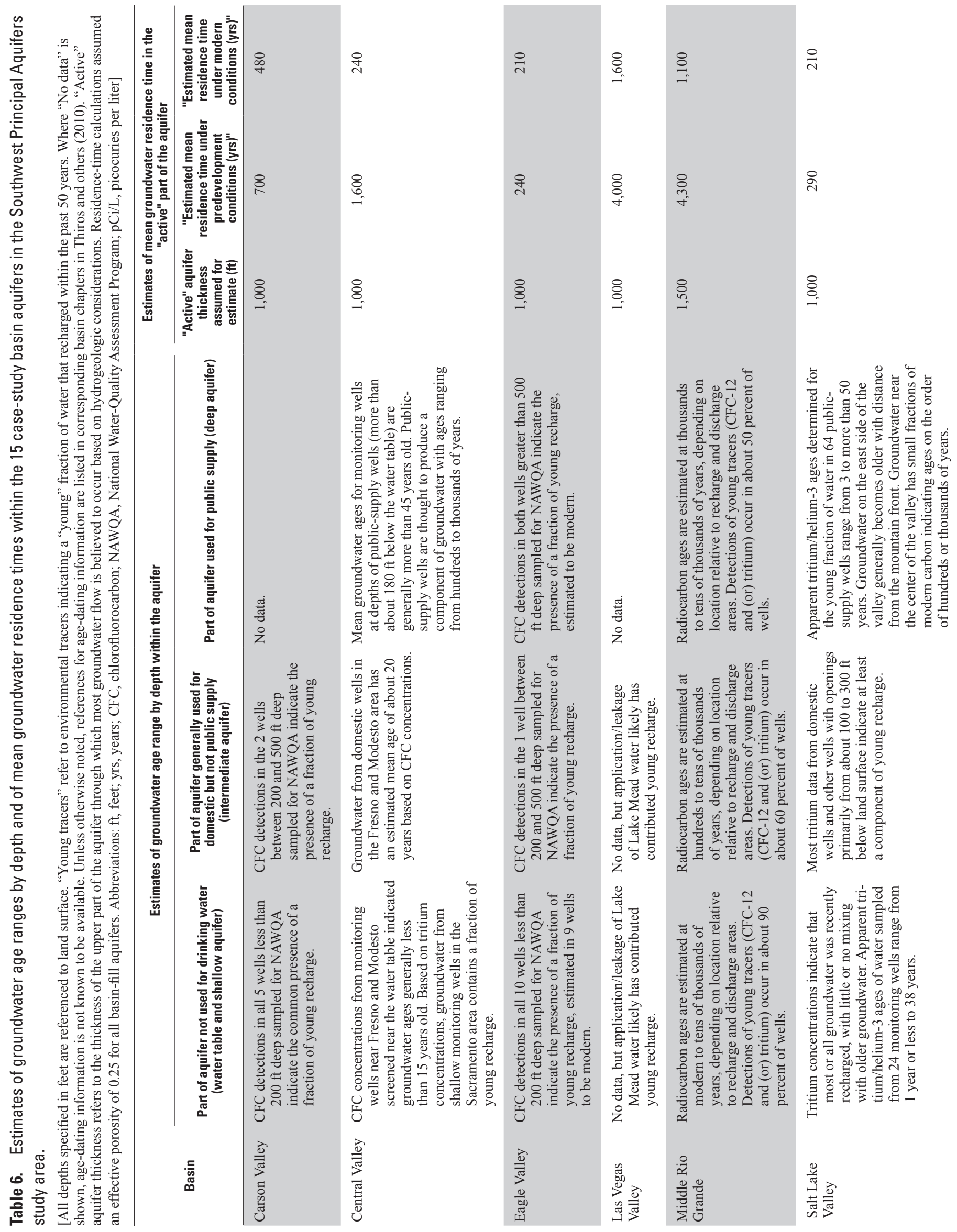




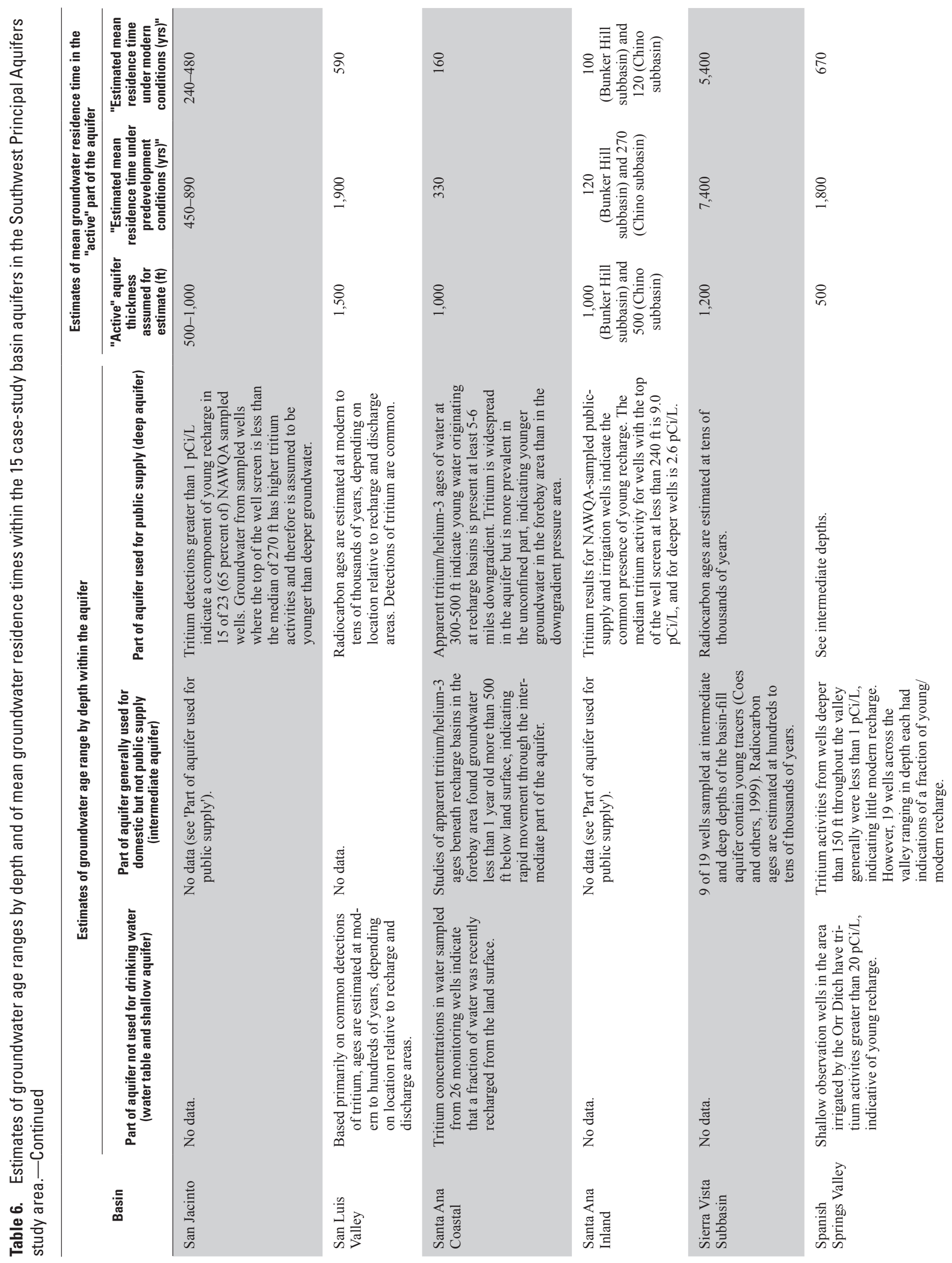




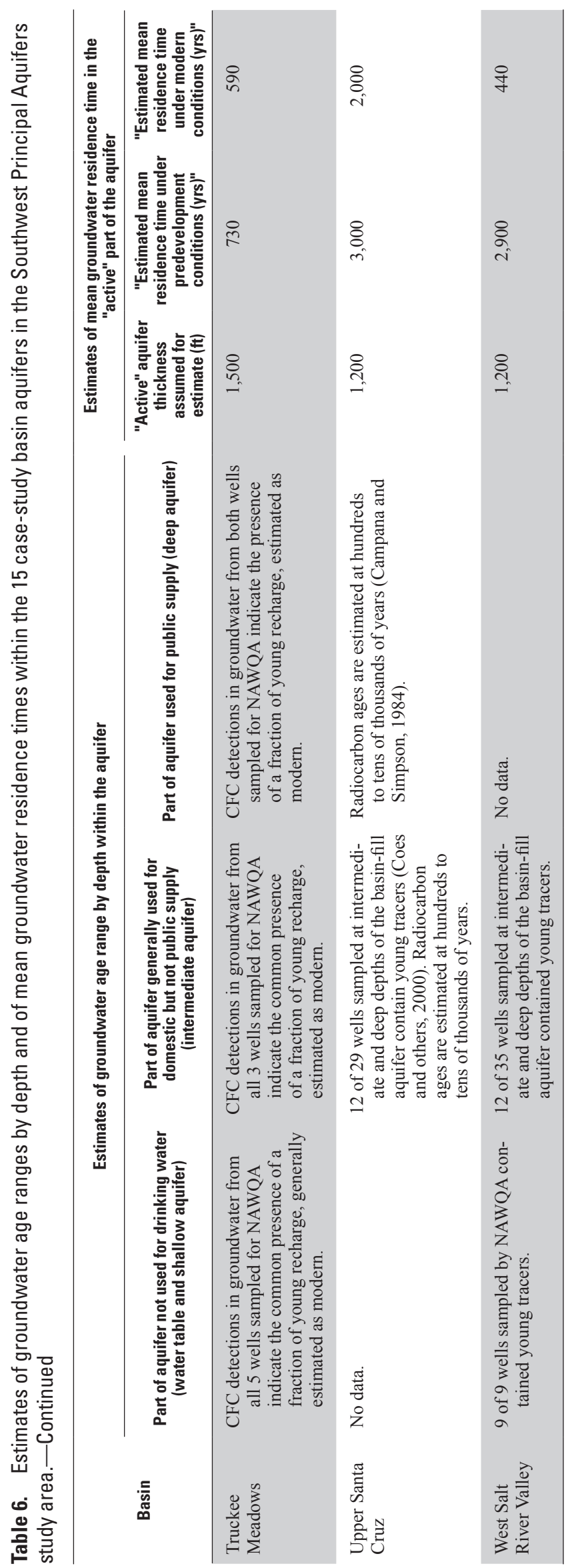

through the groundwater system and of the portion of the aquifer likely to contain water that recharged in modern times. In general, groundwater residence times are too long to measure directly with chemical tracers. Instead, a mean groundwater residence time in years can be estimated by dividing the approximate aquifer volume by the estimated annual recharge rate, assuming no change in aquifer storage (or minimal change in aquifer storage relative to aquifer volume). Estimated mean groundwater residence times under predevelopment and modern conditions were calculated for the 15 case-study basins using estimated annual recharge rates (fig. 9), estimated mean aquifer thicknesses, and an estimated effective porosity for aquifer sediments in southwestern basin-fill aquifers (table 6). The effective porosity represents the fraction of the total volume of aquifer sediments through which groundwater flow is effectively taking place (that is, the fraction of interconnected pore space). Estimates of groundwater residence time were calculated for this study using an effective porosity of 0.25 , on the basis of the general range of effective porosity values reported in the literature for unconsolidated sand and gravel aquifers (Gelhar and others, 1992; Stephens and others, 1998).

Selection of a mean aquifer thickness to assign to each aquifer is difficult because of generally insufficient information about the variability of aquifer thickness across a basin and the heterogeneity of aquifer sediments. Aquifer sediments generally decrease in hydraulic conductivity with increasing depth as a result of compaction and other factors. Consequently, most of the groundwater moving through relatively deep southwestern basin-fill aquifers actually travels through only a fraction of the entire aquifer thickness, with velocities and volumes of groundwater flow at greater depths being negligible by comparison. For the case-study basins, residence time in the upper, "active" part of the aquifer is the residence time of interest. The thickness of the "active" part of each basin-fill aquifer was generally estimated using knowledge of the hydrogeology and of the depth of deeper public-supply wells, which commonly are completed to the bottom of the most productive part of the aquifer. For some basins with less available information or large differences in thickness depending on location, a range of likely "active" aquifer thickness was selected for use in the residence-time calculations. Because of uncertainties in estimates of both "active" aquifer thickness and annual recharge rates, results of the residence-time calculations (table 6) should be considered order-of-magnitude estimates that likely are biased low for the aquifer as a whole (because less than the full thickness of basin-fill deposits was used in calculations). Despite the uncertainties, these residence-time estimates are quite useful in illustrating differences among the case-study basins, and between predevelopment and modern conditions, with respect to the portion of the used aquifer that is likely to contain a substantial fraction of young water.

As the values in table 6 illustrate, mean groundwater residence times in the "active" part of the aquifer under predevelopment conditions likely varied over more than 1.5 orders of magnitude, from about 100 to several thousands of years. In basins with estimated mean predevelopment residence times 
of about 1,000 years or less (Carson Valley, Eagle Valley, Salt Lake Valley, San Jacinto Basin, Santa Ana Coastal Basin, Truckee Meadows, and both subbasins of the Santa Ana Inland Basin), the portion of the aquifer containing water less than 50 years in age would be much greater than in basins with estimated residence times of about 3,000 years or longer (Las Vegas Valley, Middle Rio Grande, Sierra Vista subbasin, Upper Santa Cruz, and West Salt River Valley). The basins with the longest residence times would generally be more likely to have higher concentrations of natural contaminants that result from long contact times and would take longer to flush out any introduced contaminants. The mean residence times in the "active" part of the aquifer calculated for basins with available data on radiocarbon age compare reasonably well with those data, particularly considering that direct comparisons between estimated radiocarbon ages and mean residence times is not possible because of several factors including variability in the lengths of actual flow paths between recharge and discharge areas, the positions where individual sampled wells fall along those flow paths, and the depths of the aquifer represented by samples from those wells.

Estimated mean groundwater residence times in the "active" part of the aquifer under modern conditions, with the introduction of artificial recharge and groundwater pumping, are shorter for all basins than under predevelopment conditions, as would be expected. The range in the decrease of residence times is from about 10 percent (Eagle Valley) to about 85 percent (Central Valley and West Salt River Valley), or about 30 years or less (Eagle Valley and Bunker Hill subbasin of the Santa Ana Inland Basin) to about 2,400 years or more (Las Vegas Valley, Middle Rio Grande, and West Salt River Valley). These decreases in mean residence times illustrate the importance of artificial recharge and groundwater pumping in moving water more quickly through the aquifer, increasing the area that is likely to be affected by recent recharge containing anthropogenic contaminants. The modern mean residencetime calculations were examined for errors from the effects of up to 50 years of declines in aquifer storage at recent levels (associated with pumping) on the aquifer volume part of the residence-time calculation; residence times were affected by only about 1 percent or less because of the vast areal extent and thickness of the aquifer relative to the magnitude of waterlevel decline.

\section{Human Alterations to Groundwater Movement and Discharge}

Human activities can substantially alter the path that groundwater takes through an aquifer and the locations and quantities at which groundwater discharges. Changes in the location and quantity of recharge that result from artificial sources alter hydraulic head gradients in the aquifer, changing the direction (horizontally and vertically) and the velocity of groundwater flow. The typical result of artificial recharge is a wider spatial distribution of young groundwater that is more likely to contain human-related contaminants. In substantial quantities, groundwater pumping for any of the most common uses (irrigation, domestic, and public supply) can also alter flow patterns. In many alluvial basins of the Southwest, groundwater withdrawals are the single largest mechanism of discharge under modern conditions. Pumping from deep wells can enhance movement of human-related contamination from the water table to parts of the aquifer that commonly are used for public supply by lowering hydraulic heads in deeper parts of the aquifer, either inducing larger downward gradients or causing gradients to reverse from upward to downward. Even when not in use, deep wells that are screened over large intervals can provide pathways for vertical groundwater movement.

Although the degree to which groundwater flow directions have been altered by artificial recharge sources has not been thoroughly assessed for all Southwestern alluvial basins, the resulting changes have been well documented for some basins where they have been particularly dramatic. For example, in the San Joaquin Valley of California (the southern part of the Central Valley), seepage of excess irrigation water applied to crops recharges the water table in the center of the valley, which was exclusively a discharge area under predevelopment conditions. The combination of increased recharge to the water table and increased pumping from deeper parts of the aquifer has caused a reversal in the direction of the hydraulic gradient from upward to downward (Williamson and others, 1989). This change has increased the susceptibility of both shallow and deeper parts of the aquifer in the center of the valley, where young water can now be observed more than 100 $\mathrm{ft}$ below the water table (Burow and others, 2008). In the Salt Lake and San Luis Valleys, seepage from irrigation canals and (or) irrigated fields has resulted in a localized water-table rise of as much as $50 \mathrm{ft}$, thereby increasing saturated thicknesses. The resulting groundwater mounds change the magnitude of hydraulic gradients, resulting in flow away from the area of increased recharge.

In 11 of the 15 SWPA case-study basins, more than half of the groundwater discharge from the basin-fill aquifer under modern conditions is the result of pumping (fig. 9). Groundwater pumping accounts for about 75 percent or more of groundwater discharge in the Las Vegas Valley, San Jacinto Basin, Santa Ana Coastal Basin, Santa Ana Inland Basin, Spanish Springs Valley, Upper Santa Cruz Basin, and West Salt River Valley. Among all 15 basins, the total quantity of groundwater pumping ranges from about 5,400 acre-ft/yr for Spanish Springs Valley to about 9.3 million acre-ft/yr for the Central Valley (fig. 13). When averaged over the basin area, pumping ranges from about $0.4 \mathrm{in} / \mathrm{yr}$ in the Sierra Vista subbasin to $28.2 \mathrm{in} / \mathrm{yr}$ in the Bunker Hill subbasin of the Santa Ana Inland Basin.

Relative to predevelopment conditions, discharge through groundwater pumping typically results in substantial decreases in the quantity of water discharged through the natural processes of evapotranspiration, spring flow, net stream gain, and (or) subsurface outflow. In some cases, the primary 


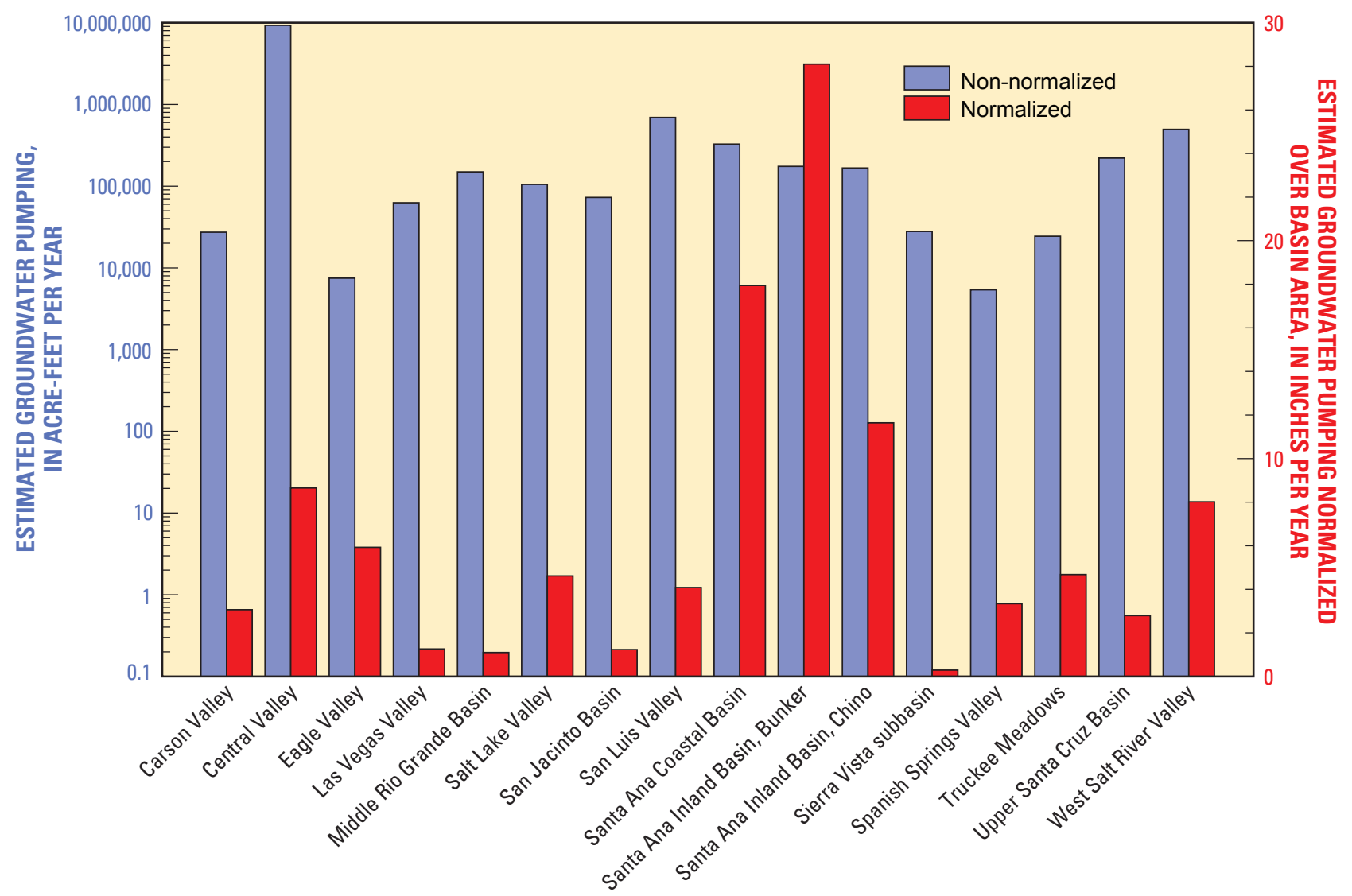

Figure 13. Estimated quantities of groundwater pumping from case-study basins in the Southwest Principal Aquifers study area under modern conditions.

mechanisms of groundwater discharge under predevelopment conditions essentially cease. For example, in the Bunker Hill subbasin of the Santa Ana Inland Basin, the large amount of groundwater pumping has reduced the combined quantity of natural discharge through evapotranspiration, net stream gain, and subsurface outflow by almost 90 percent. Large changes in the quantity of discharge through natural mechanisms are indicative of the changes in flow directions that have resulted from substantial quantities of groundwater pumping. Pumping captures groundwater that otherwise would have continued on a path to a natural discharge area and can even induce greater recharge from streams in hydraulic connection with the aquifer. Groundwater pumping in the Albuquerque area of the Middle Rio Grande Basin has resulted in increased infiltration of surface water from the Rio Grande. Where pumping induces recharge from streams that previously only gained flow, the aquifer becomes susceptible to contamination from constituents present in this new source of recharge.

In sufficient quantities, pumping results in not just slight changes to the direction and magnitude of hydraulic gradients but in reversals of flow directions and removal of groundwater from aquifer storage. Despite the large quantities of artificial recharge that have been introduced to many of the SWPA case-study basins, pumping from most of these basins has caused increases in discharge between predevelopment and modern conditions to exceed increases in recharge (fig. 14). In the 10 case-study basins where groundwater discharge is currently estimated to exceed recharge by at least 1,000 acre-ft/yr, the quantity of water being removed from aquifer storage annually is as much as 1.3 million acre-ft (fig. 9). The largest estimated decrease in aquifer storage is in the Central Valley, where water-level declines of more than 400 $\mathrm{ft}$ have been observed. Water-level declines of at least $100 \mathrm{ft}$ also have been observed in other case-study basins, including the Las Vegas Valley, Middle Rio Grande, Santa Ana Inland, Upper Santa Cruz, and West Salt River Valley. Such declines typically have substantially altered regional flow directions (see the text box, "Water-Level Changes in the West Salt River Valley"). They also have caused or enhanced downward vertical movement of groundwater from shallower to deeper parts of the aquifer system, increasing the susceptibility of deeper parts of the aquifer to contamination. Although this enhanced downward movement of shallow groundwater can result in a higher frequency of contaminant detection at greater depths, the resulting mixing with deeper groundwater (which is generally less likely to have been affected by human-related contamination) can dilute contaminants, resulting in lower concentrations. 


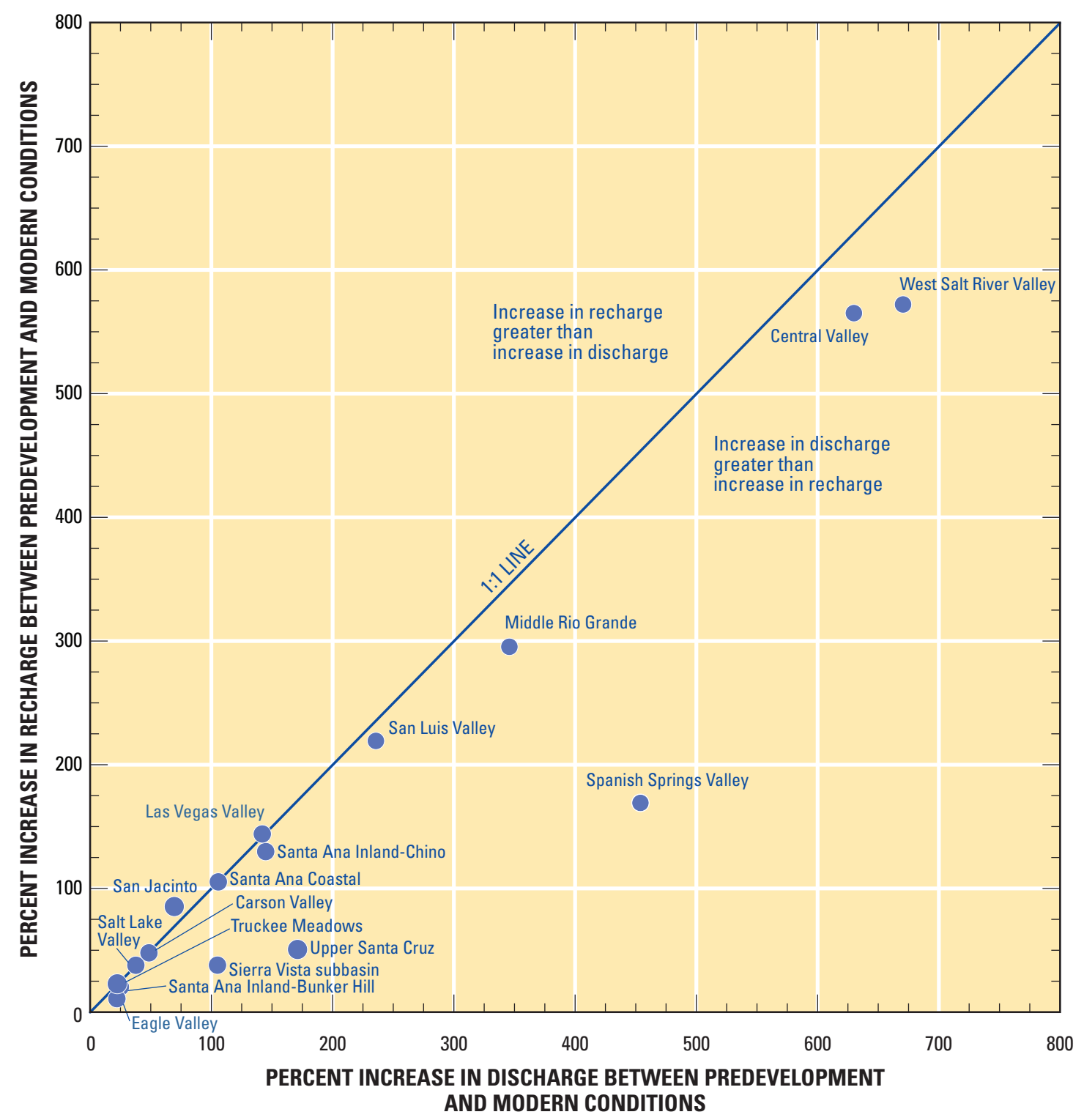

Figure 14. Relation between increase in recharge and increase in discharge between predevelopment and modern conditions for the 15 case-study basins in the Southwest Principal Aquifers study area.

Deeper groundwater wells (most of which are used for public supply, but some of which are intended for other uses such as irrigation) can affect aquifer susceptibility in ways other than the alteration of hydraulic gradients through groundwater withdrawals. These wells typically are open to the aquifer over large depth intervals that differ in hydraulic head. Even when the wells are not pumping, groundwater tends to flow through the wellbores, which provide a preferential path for vertical movement (fig. 15). In areas where ambient hydraulic gradients are downward, young water can move down wellbores into deeper parts of the aquifer, increasing the susceptibility of the aquifer to contamination at depths that are used for public supply. Such downward migration of shallow groundwater along a wellbore to deeper parts of the aquifer has been documented to affect uranium concentrations and detections of VOCs and pesticides in and near a public-supply well in Modesto, California (Jurgens and others, 2008). In the case of a well that is screened across multiple aquifers, young water can move from a shallower aquifer that is not used for public supply to a deeper one that is. In areas where hydraulic gradients are upward, wellbores can provide pathways for older water that might have elevated concentrations of natural contaminants to move into shallower parts of the aquifer where natural contaminants are not typically a problem.

Wells are not the only manmade discharge features that can alter groundwater flow directions and discharge quantities. Groundwater drains have been constructed in many agricultural areas of the Southwest to maintain the water table at a sufficient depth below land surface to allow sustained irrigated agriculture without damaging crops. These groundwater drains 


\section{Water-Level Changes in the West Salt River Valley}

The groundwater flow system of the West Salt River Valley has been substantially reshaped by water development, especially as a result of withdrawals from regional pumping centers as well as incidental recharge from canal seepage and irrigation losses on croplands and turf (Corkhill and others, 1993; Corkhill and others, 2004). Groundwater discharge from predevelopment conditions to 2005 increased about eightfold as a result of groundwater pumping (Thiros and others, 2010). While much of this deficit is counterbalanced by recharge from canal seepage and irrigation losses, there is still a net decrease in groundwater storage. As of 1988, total storage depletion over time was about 23 million acre-ft (Corkhill and others, 1993).

Storage depletion has resulted in large water-level declines in most areas and downward hydraulic gradients in many areas (Corkhill and others, 1993). The largest declines occur in regional pumping centers north and west of Sun City, where water levels have fallen between 300 and 400 feet (Anderson and others, 1992). In the southern part of the basin waterlevel changes are much less dramatic. Declines are less than 50 feet near the Salt and Gila
Rivers, owing to more reliance on surface-water supplies and treated municipal effluent than on groundwater, and to incidental recharge from irrigation using those supplies.

Groundwater movement has changed direction as a result of water-level declines, and now flows toward large depressions in the water table caused by regional pumping centers, such as those mentioned to the north and west of Sun City (Corkhill and others, 1993). In the vicinity of such depressions, groundwater flow changed from primarily horizontal under predevelopment conditions to include an additional downward component under developed conditions. Currently, groundwater also flows away from apparent mounds near Goodyear and between Glendale and Sun City, which are essentially relict areas where water levels fell less than in surrounding areas.

\section{EXPLANATION}

Approximate boundary for listed water-level decline, in feet Approximate boundary of basin-fill sediments Groundwater-flow direction, 2005 Groundwater-flow direction, predevelopment

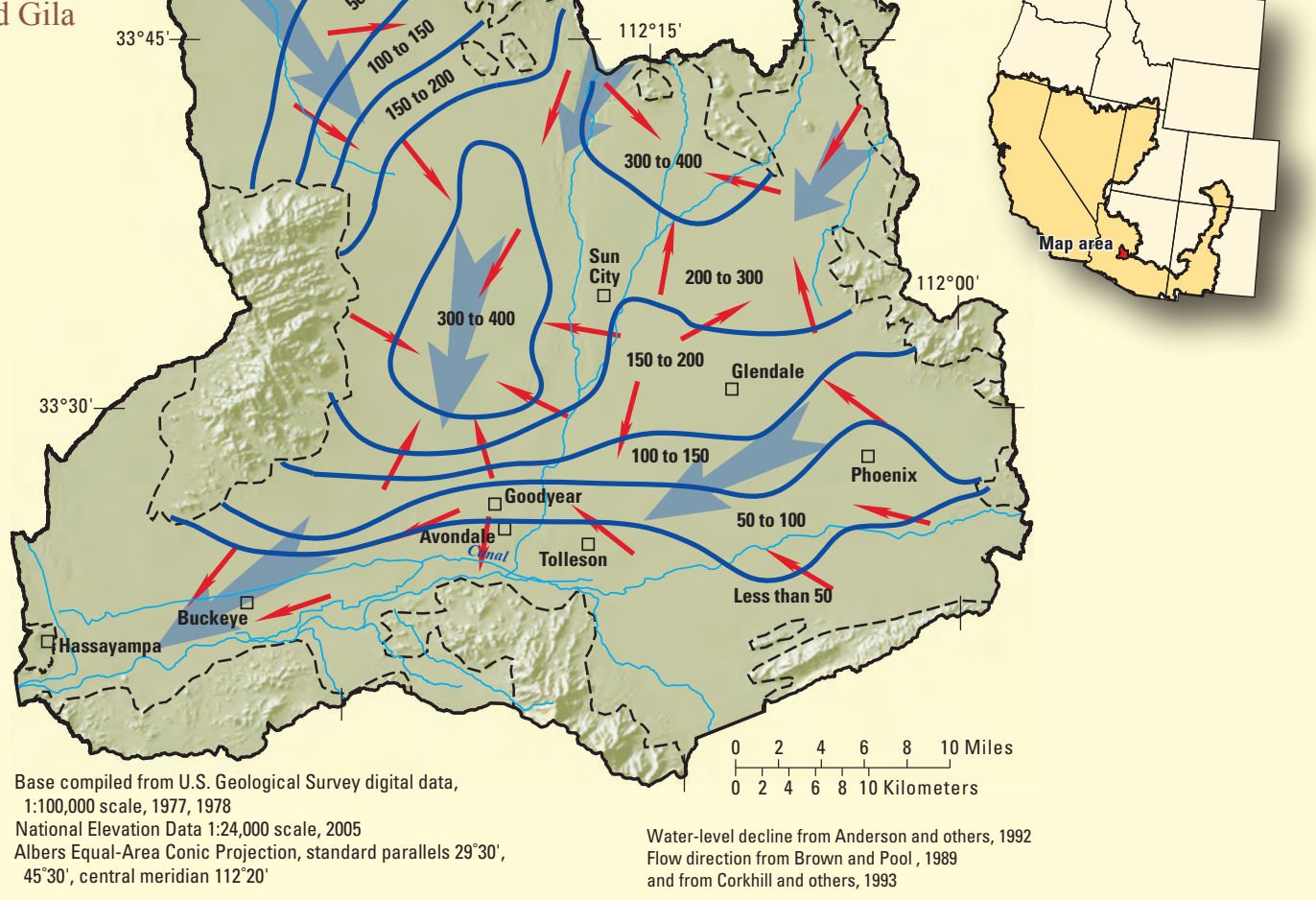




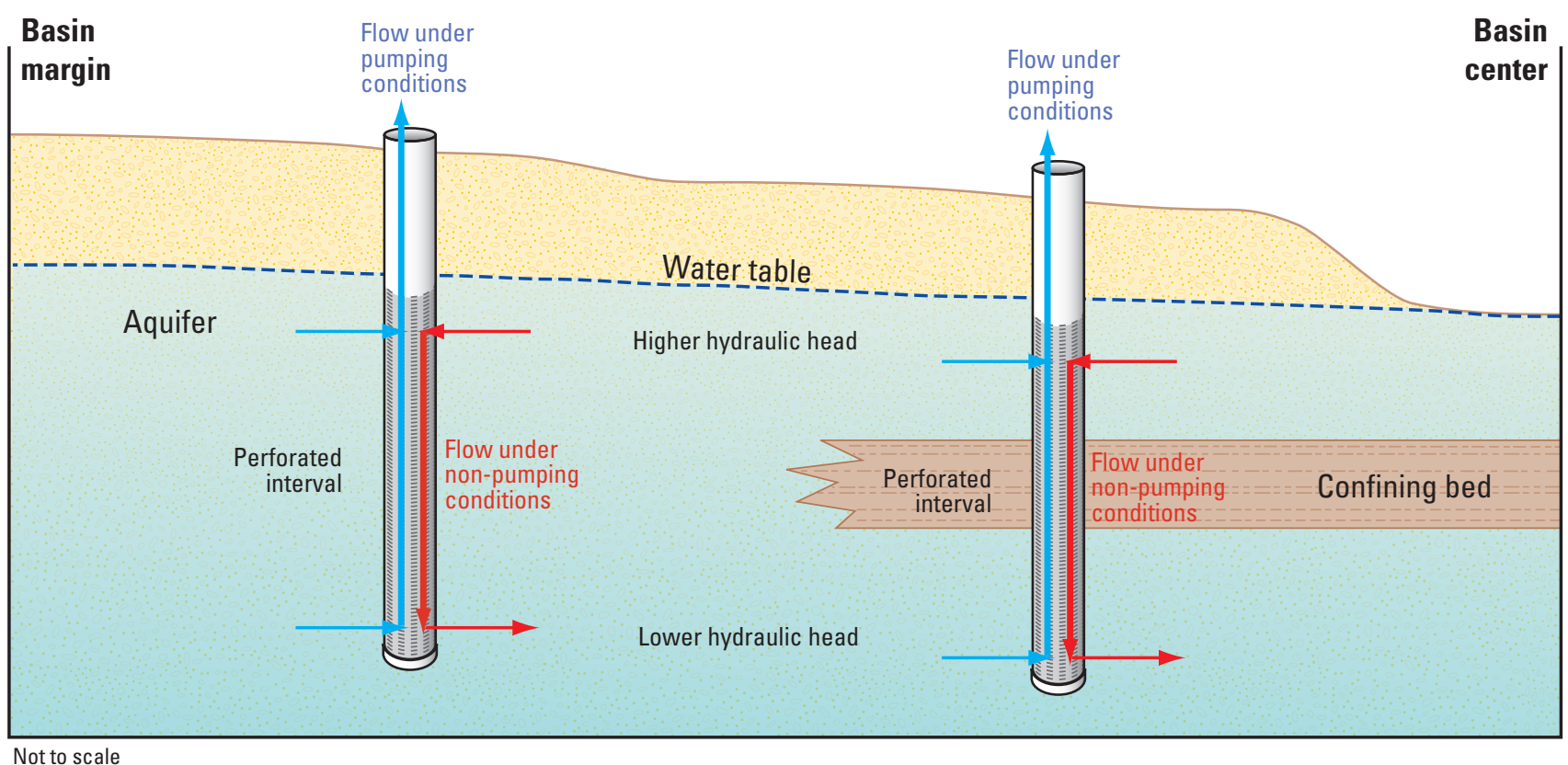

Figure 15. Generalized diagram of the potential influence of deep wells on vertical groundwater flow in an alluvial basin.

primarily capture water that has seeped through irrigated fields and from irrigation canals, although in some systems deeper regional groundwater might also discharge to the drains. In the case of the Middle Rio Grande Basin, drains also intercept leakage from the Rio Grande; the drain system eventually returns all captured water to the river, increasing the flux between the groundwater and surface-water systems. Construction of a groundwater drainage system can also affect groundwater discharge by lowering the water table sufficiently to reduce evapotranspiration from native riparian vegetation and wetlands. In the Middle Rio Grande Basin, for example, the largest component of outflow from the aquifer system has shifted from riparian evapotranspiration under predevelopment conditions to discharge to the groundwater drain system under modern conditions (fig. 9). Much of the water captured by groundwater drains is shallow groundwater that is most susceptible to increases in dissolved-solids concentrations through evapotranspiration and to the presence of agricultural chemicals. The drains can, therefore, negatively impact the quality of streams or other surface-water features into which the drains are emptied, while simultaneously helping to protect the deeper groundwater system from contaminated shallow groundwater that might otherwise migrate downward.

\section{Aquifer Properties}

Several basic types of aquifer properties can largely determine the susceptibility of groundwater in a particular basin-fill aquifer to contamination. Several of these properties are intrinsic to the aquifer and are essentially unalterable on a broad scale, whereas others can be influenced to some degree by human activities. The grain size, sorting, and other properties of the sedimentary deposits composing a basin-fill aquifer will result in a certain distribution of hydraulic conductivity, which might or might not include extensive zones of very low conductivity. This distribution of hydraulic conductivity, which is not substantially altered by human activities, affects groundwater traveltimes and the connection between shallower and deeper parts of an aquifer. Along with the distribution of hydraulic conductivity, the distribution and quantity of recharge to and discharge from a basin-fill aquifer exert primary control over unsaturated-zone thickness and the general direction and magnitude of vertical hydraulic gradients. These properties, which can be altered by artificial recharge and discharge, affect the ability of contaminants to reach the water table and to be transported to greater depths, respectively. A variety of hydrologic and geologic factors determine the redox conditions and $\mathrm{pH}$ range of groundwater in a basin-fill aquifer, which can be altered (only locally in most cases) by human activities. Redox and $\mathrm{pH}$ are both important controls on contaminant transport and fate.

Along with the magnitude of hydraulic gradients and the porosity of aquifer materials, the distribution of hydraulic conductivity within an aquifer is a primary control on groundwater flow velocities and, therefore, traveltimes. Given the same hydraulic gradient and porosity, groundwater will travel more quickly through aquifer materials with higher hydraulic conductivity, resulting in generally younger apparent groundwater ages and faster migration of dissolved contaminants. Thus, higher hydraulic conductivities result in broader areas of an aquifer being susceptible to contamination at any given time - although higher conductivities can also translate into faster flushing of contaminants through (and out of) the groundwater system. Because basin-fill aquifers of the Southwest are composed of broadly similar materials (gravel, sand, silt, and clay), they tend to have similar values of porosity and 
similar ranges of hydraulic conductivity (table 7), generally estimated to be about $1 \mathrm{ft} / \mathrm{d}$ or less for the least conductive sediments to hundreds of feet per day for the most conductive sediments. However, differences in the distribution of hydraulic conductivity among the basins have important implications for groundwater flow and contaminant transport.

As a result of past low-energy depositional environments, basin-fill deposits within several of the SWPA case-study basins include clay layers of very low hydraulic conductivity that are thick and extensive enough to substantially affect the hydraulic connection between parts of the basin-fill aquifer above and below them. These thick clay layers, which generally are present across broad areas of valley floors, impede downward movement of groundwater - and, therefore, of contaminants-between the shallow groundwater system and the deeper system typically used for domestic or public supply. As a result, susceptibility of deeper parts of the aquifer system to contamination generally is lower in basins where such clay layers are present. A similar protective effect can be provided by thinner, more discontinuous fine-grained layers if they are sufficiently numerous. As indicated in table 7, more than half of the SWPA case-study basins have clay layers capable of impeding vertical groundwater movement in at least some areas. The effects of extensive clay layers on groundwater flow in the Alamosa Basin of the San Luis Valley with respect to impeding downward flow that is common near basin margins are illustrated in figure 8. Although low-conductivity layers typically are protective of deeper aquifer zones, if these layers happen to become saturated with contaminants such as certain VOCs, they can instead act as reservoirs that slowly release those contaminants to higher-conductivity layers over long periods of time.

Unsaturated-zone thickness is an important control on whether dissolved contaminants being transported in water that infiltrates into the soil ultimately reach the water table and, if so, when and at what concentrations. All other factors being equal, the thicker the unsaturated zone, the longer it will take for infiltrating water to reach the water table and the more likely it is that any dissolved contaminants will sorb or degrade during infiltration. In areas where infiltration associated with precipitation events typically does not produce recharge (which is common in the Southwest because of relatively low rates of precipitation relative to evapotranspiration), solutes can build up over time, resulting in high solute concentrations in water that does recharge periodically. In Southwestern alluvial basins overall, soil properties might generally be less important of a factor than unsaturated-zone thickness in hindering downward movement of water from the land surface to the water table because of the general lack of very clayey soils in most areas. However, where less permeable sediment layers are present, they tend to retard infiltration and contaminant transport.

Unsaturated-zone thickness is determined largely by topography in combination with the distribution and quantity of recharge and discharge, with some additional effect from the distribution of hydraulic conductivity. Thus, unsaturatedzone thickness can be altered by human activities such as the addition of quantities of artificial recharge sufficient to cause a water-table rise, or the withdrawal of quantities of groundwater sufficient to cause a water-table decline. Under natural conditions, patterns of unsaturated-zone thickness tend to be similar among many Southwestern alluvial basins. In general, the depth to water is less than $50 \mathrm{ft}$ beneath some part of the valley floor near the central part of the basin and from 50 to several hundred feet beneath upland areas. This range of unsaturated-zone thickness is common among the 15 case-study basins (table 7), although the portion of the basin underlain by a thinner (less than $50-\mathrm{ft}$ thick) unsaturated zone can vary widely.

The vertical hydraulic gradients in a specified area of an aquifer determine whether groundwater flow in that area is generally upward or downward. In areas of generally upward vertical gradients, the deeper groundwater system tends to be protected from human-related contamination at or near the land surface, even if contaminants reach the water table and migrate though the shallow part of the aquifer. However, in these same areas, the quality of water in the shallower groundwater system could be degraded by upward mixing of older groundwater that has relatively high concentrations of natural contaminants as a result of long contact times and (or) travel through varying redox zones. In areas of generally downward vertical gradients, human-related contaminants that reach the water table are likely to migrate to the deeper groundwater system over time. The time scale of downward contaminant migration will depend on the magnitude of the hydraulic gradients, along with the hydraulic conductivity and porosity of the aquifer materials. Under natural conditions, vertical hydraulic gradients in Southwestern alluvial basins tend to be downward along basin margins (where recharge generally occurs) and upward in the central part of the valley floor (where discharge generally occurs) (table 7). However, because hydraulic gradients are largely the result of the distribution and quantity of recharge and discharge, they can be strongly affected by human activities. Both artificial recharge and groundwater pumping can enhance downward gradients or even cause the direction of gradients to reverse from upward to downward.

The redox conditions and $\mathrm{pH}$ range of groundwater are primary controls on contaminant fate in an aquifer, affecting the degree to which natural attenuation of contaminants will occur through chemical transformation or sorption. Under natural conditions, redox and $\mathrm{pH}$ of groundwater are largely determined by the chemical composition and organic-carbon content of rocks and sediments encountered along a flow path and by rates of recharge and discharge. Oxic conditions (dissolved-oxygen concentrations exceeding about $0.5 \mathrm{mg} / \mathrm{L}$; see text box, "How Redox Conditions are Determined") are conducive to the degradation of some contaminants, such as many petroleum hydrocarbons, whereas anoxic conditions (dissolved-oxygen concentrations less than about $0.5 \mathrm{mg} / \mathrm{L}$ ) are conducive to the degradation of others, such as solvents 
Table 7. Summary of aquifer properties that are important to characterization of intrinsic susceptibility and vulnerability within the 15 case-study basins in the Southwest Principal Aquifers study area.

[Thicker unsaturated zones can help prevent contaminants from reaching the aquifer. Presence of extensive, thick, and non-leaky confining units can substantially impede contaminant migration from shallower to deeper parts of the aquifer, as can consistently upward vertical hydraulic gradients. Larger horizontal hydraulic conductivity values allow for the possibility of generally faster migration of contaminants through the aquifer. Unless otherwise noted, references for the information presented here are listed in corresponding basin chapters in Thiros and others (2010). Abbreviations: $\mathrm{ft}$, feet; ft/d, feet per day; <, less than; bls, below land surface; \%, percent]

\begin{tabular}{|c|c|c|}
\hline Basin & $\begin{array}{c}\text { Estimated range of unsaturated-zone } \\
\text { thickness }\end{array}$ & Confining layers \\
\hline Carson Valley & $\begin{array}{l}\text { Very thin (about } 5 \mathrm{ft} \text { ) near basin } \\
\text { center because a high water table } \\
\text { is maintained by infiltration of } \\
\text { irrigation water that is diverted } \\
\text { across the valley floor through } \\
\text { canals, ditches, and flood-irrigated } \\
\text { fields. Generally deeper (greater } \\
\text { than } 200 \mathrm{ft} \text { ) near basin margins, } \\
\text { beneath alluvial fans. }\end{array}$ & $\begin{array}{l}\text { No single confining layer. } \\
\text { Scattered discontinuous clay } \\
\text { beds, } 30 \text { to } 70 \mathrm{ft} \text { thick, occur at } \\
\text { a depth of } 200 \text { to } 300 \mathrm{ft} \text {. }\end{array}$ \\
\hline Central Valley & $\begin{array}{l}\text { Ranges from near land surface along } \\
\text { parts of the valley axis to about } \\
400 \mathrm{ft} \text { along some parts of the } \\
\text { valley margins. Less than } 50 \mathrm{ft} \text { to } \\
\text { water across much of the basin. }\end{array}$ & $\begin{array}{l}\text { Numerous discontinuous fine- } \\
\text { grained lenses locally act as } \\
\text { confining layers to interbedded } \\
\text { sand and gravel layers. The } \\
\text { Corcoran Clay is an areally } \\
\text { extensive layer of lacustrine } \\
\text { clay that separates basin- } \\
\text { fill deposits into an upper } \\
\text { unconfined to semiconfined } \\
\text { zone and a lower confined } \\
\text { zone where present in the San } \\
\text { Joaquin Valley, generally from } \\
\text { its axis to its western margin. }\end{array}$ \\
\hline Eagle Valley & $\begin{array}{l}\text { Thinner near basin center }(5-25 \mathrm{ft} \\
\text { thick) and thicker near the basin } \\
\text { margins ( } 50-250 \mathrm{ft} \text { thick) } \\
\text { (unpublished USGS data). }\end{array}$ & $\begin{array}{l}\text { Clay layers are present in the } \\
\text { central part of the basin but are } \\
\text { discontinuous. }\end{array}$ \\
\hline Las Vegas Valley & $\begin{array}{l}\text { The central part of the basin generally } \\
\text { has }<50 \mathrm{ft} \text { of unsaturated zone, } \\
\text { although depth to water increases } \\
\text { radially out from the center. } \\
\text { Unsaturated-zone thickness in the } \\
\text { south-central part of the basin is } \\
\text { about } 30 \mathrm{ft} \text {. }\end{array}$ & $\begin{array}{l}\text { Clays or caliche deposits } \\
\text { typically occur within } 50 \mathrm{ft} \text { of } \\
\text { land surface. Layers and lenses } \\
\text { of sand and gravel become } \\
\text { separated by layers of clay and } \\
\text { silt, resulting in semiconfined } \\
\text { to confined conditions in the } \\
\text { principal aquifer towards the } \\
\text { middle of the valley. }\end{array}$ \\
\hline
\end{tabular}

Middle Rio Grande $\begin{gathered}\text { Less than } 50 \mathrm{ft} \text { across most of the } \\ \text { Rio Grande inner valley and near } \\ \text { the Jemez River; generally larger } \\ \text { elsewhere, ranging to more than } \\ 900 \mathrm{ft} \text { beneath the West Mesa. }\end{gathered}$
Salt Lake Valley $\quad \begin{aligned} & \text { Ranges from near land surface along } \\ & \text { the basin axis to more than } 500 \mathrm{ft} \\ & \text { along parts of the basin margins. } \\ & \text { Less than } 50 \mathrm{ft} \text { to water across } \\ & \text { much of the eastern part of the } \\ & \text { basin. }\end{aligned}$

No extensive confining layers.

Direction of vertical hydraulic

gradients

Downward near basin margins and A pump test indicated values of upward near the basin center. about $15 \mathrm{ft} / \mathrm{d}$.

No change in gradients under modern conditions.

\begin{tabular}{|c|c|c|c|c|}
\hline San Jacinto & $\begin{array}{l}\text { Ranges from near land surface where } \\
\text { the San Jacinto River and Salt } \\
\text { Creek exit the basin to about } 100 \\
\mathrm{ft} .\end{array}$ & $\begin{array}{l}\text { Layers of fine-grained material in } \\
\text { the lower parts of the eastern } \\
\text { subbasins confine deeper parts } \\
\text { of the basin-fill aquifer. No } \\
\text { extensive confining layers are } \\
\text { present in the western sub- } \\
\text { basins. }\end{array}$ & $\begin{array}{l}\text { Downward near the basin margins } \\
\text { and in much of the basin. Up- } \\
\text { ward where faults and bedrock } \\
\text { constrict flow. }\end{array}$ & $\begin{array}{l}\text { Hydraulic conductivities estimated } \\
\text { for the western subbasins from } \\
\text { transmissivities reported by the } \\
\text { Eastern Municipal Water District } \\
(2005) \text { and an assumption that the } \\
\text { wells were open to about } 300 \mathrm{ft} \\
\text { of saturated material range from } \\
\text { about } 1 \text { to } 50 \mathrm{ft} / \mathrm{d} \text {. }\end{array}$ \\
\hline
\end{tabular}

San Luis Valley Less than $50 \mathrm{ft}$ (and commonly less than $25 \mathrm{ft}$ ) throughout most of the Alamosa Basin, which covers roughly half of the valley; $80 \mathrm{ft}$ or more near basin margins.
Leaky clay confining layers interbedded with sand extend throughout most of the Alamosa Basin (except at margins), beginning at about $60-120 \mathrm{ft}$ bls and varying from about 100 to $1,200 \mathrm{ft}$ thick.
Under predevelopment conditions, Model-simulated hydraulic the vertical gradient was downward around the margins of the valley and upward in the center. Under modern conditions, the combination of increased recharge to the water table and groundwater pumping from the lower confined zone has reversed the direction of the hydraulic gradient from upward to downward in areas in the center of the valley.

Downward near basin margins and Ranges from about 1 to $31 \mathrm{ft} / \mathrm{d}$ in upward near the basin center. No change in gradients in modern conditions. shallow sediments and from 0.03 to $155 \mathrm{ft} / \mathrm{d}$ in the deeper, coarser and more transmissive part of the aquifer.

Generally downward near basin margins and upward near the basin center. The combination of

Rough estimates based on transmissivities range from about increased recharge to the water table and increased pumping from the lower confined zone has reversed the direction of the hydraulic gradient from upward to downward in the center of the valley. conductivities in Sacramento coarse-grained material. Simulated hydraulic conductivities in San Joaquin Valley were $0.024 \mathrm{ft} / \mathrm{d}$ for fine-grained material and $330 \mathrm{ft} / \mathrm{d}$ for coarse-grained material. Valley were $0.075 \mathrm{ft} / \mathrm{d}$ for fine-
Downward near the mountain front, in and west of the Rio Grande inner valley; upward beneath most of the East Mesa.
$0.05 \mathrm{ft} / \mathrm{d}$ for the lower Santa Fe Formation to $325 \mathrm{ft} / \mathrm{d}$ for postSanta Fe Group alluvium; typical values $1.5-60 \mathrm{ft} / \mathrm{d}$.
Clay lenses and layers confine deeper parts of the basin-fill aquifer, except near the basin margins.
Downward near the basin margins Typically range from 1 to $200 \mathrm{ft} / \mathrm{d}$. and upward along the basin axis and in discharge areas.
Downward along the margins of the Alamosa Basin and upward near the basin center.
$0.1 \mathrm{ft} / \mathrm{d}$ for lower Santa Fe Formation to $400 \mathrm{ft} / \mathrm{d}$ for coarse Rio Grande alluvium and alluvial fan deposits; typical values 5-100 ft/d. 
Table 7. Summary of aquifer properties that are important to characterization of intrinsic susceptibility and vulnerability within the 15 case-study basins in the Southwest Principal Aquifers study area.-Continued

\begin{tabular}{|c|c|c|c|c|}
\hline Basin & $\begin{array}{l}\text { Estimated range of unsaturated-zone } \\
\text { thickness }\end{array}$ & Confining layers & $\begin{array}{l}\text { Direction of vertical hydraulic } \\
\text { gradients }\end{array}$ & $\begin{array}{l}\text { Estimated range of horizontal } \\
\text { hydraulic conductivity }\end{array}$ \\
\hline Santa Ana Coastal & $\begin{array}{l}\text { Prior to development, groundwater } \\
\text { was near land surface in the } \\
\text { pressure area of the basin. Thick } \\
\text { unsaturated zones do not underlie } \\
\text { the recharge basins but occur } \\
\text { along the mountain front where } \\
\text { less recharge occurs. }\end{array}$ & $\begin{array}{l}\text { Fine-grained sediments in the } \\
\text { forebay area are laterally } \\
\text { discontinuous and generally } \\
\text { do not impede the vertical } \\
\text { movement of groundwater. } \\
\text { Relatively continuous, thick } \\
\text { layers of silt and clay at } \\
\text { shallow depths (generally } \\
\text { within the upper } 50 \mathrm{ft} \text { ) extend } \\
\text { from the western edge of the } \\
\text { forebay area to the Pacific } \\
\text { Ocean. }\end{array}$ & $\begin{array}{l}\text { Downward in the forebay } \\
\text { (eastern) part of the basin and } \\
\text { upward in the pressure (west- } \\
\text { ern) part near the Newport- } \\
\text { Inglewood Fault Zone. }\end{array}$ & $\begin{array}{l}\text { Hydraulic conductivity values } \\
\text { modeled in the forebay area } \\
\text { ranged from } 150-300 \mathrm{ft} / \mathrm{d} \text { for } \\
\text { permeable material; } 1 \mathrm{ft} / \mathrm{d} \text { was } \\
\text { used in the groundwater flow } \\
\text { model for fine-grained material. }\end{array}$ \\
\hline Santa Ana Inland & $\begin{array}{l}\text { Ranges from at land surface near the } \\
\text { San Jacinto Fault to } 300 \mathrm{ft} \text { near } \\
\text { the mountain front in the Bunker } \\
\text { Hill subbasin. Ranges from near } \\
\text { land surface in the southern and } \\
\text { western parts of the Chino sub- } \\
\text { basin to more than } 500 \mathrm{ft} \text { in the } \\
\text { northern unconfined part. }\end{array}$ & $\begin{array}{l}\text { Confining layers occur in the } \\
\text { western part of the Bunker } \\
\text { Hill subbasin and the western } \\
\text { and southwestern parts of the } \\
\text { Chino subbasin. }\end{array}$ & $\begin{array}{l}\text { Downward near the mountain } \\
\text { front and upward near the San } \\
\text { Jacinto Fault in the Bunker } \\
\text { Hill subbasin. Downward } \\
\text { through most of the Chino } \\
\text { subbasin. }\end{array}$ & $\begin{array}{l}\text { Permeable deposits in the Bunker } \\
\text { Hill subbasin are estimated to } \\
\text { range from } 40-100 \mathrm{ft} / \mathrm{d} \text {. }\end{array}$ \\
\hline $\begin{array}{l}\text { Sierra Vista Sub- } \\
\text { basin }\end{array}$ & $\begin{array}{l}\text { About } 10 \% \text { of the basin-fill aquifer } \\
\text { has depth to water less than } 50 \\
\mathrm{ft} \text {, mostly along and adjacent to } \\
\text { the San Pedro River and Lower } \\
\text { Babocomari River. Depth to } \\
\text { water is about } 500 \mathrm{ft} \text { near Fort } \\
\text { Huachuca, Benson, and the Little } \\
\text { Dragoon Mountains. }\end{array}$ & $\begin{array}{l}\text { Confining layers occur in the } \\
\text { Palominas-Hereford area, and } \\
\text { the St. David-Pomerene area. }\end{array}$ & $\begin{array}{l}\text { Downward gradients occur in } \\
\text { recharge areas along the basin } \\
\text { margins, losing reaches of the } \\
\text { San Pedro and Babocomari } \\
\text { Rivers, and areas with heavy } \\
\text { pumping; upward gradients } \\
\text { occur along gaining reaches of } \\
\text { the San Pedro River, including } \\
\text { the Palominas-Hereford and } \\
\text { St. David-Pomerene confined } \\
\text { areas. }\end{array}$ & $\begin{array}{l}\text { For the lower basin-fill sediments, } \\
\text { average values range from } 0.016 \\
\mathrm{ft} / \mathrm{d} \text { for silt and clay to } 3.2 \mathrm{ft} / \mathrm{d} \text { for } \\
\text { sand and gravel. For the upper } \\
\text { basin-fill sediments, average } \\
\text { values range from } 0.75 \mathrm{ft} / \mathrm{d} \text { for } \\
\text { silt and clay and about } 11 \mathrm{ft} / \mathrm{d} \text { for } \\
\text { sand and gravel. }\end{array}$ \\
\hline $\begin{array}{l}\text { Spanish Springs } \\
\text { Valley }\end{array}$ & $\begin{array}{l}\text { The unsaturated zone is }<50 \mathrm{ft} \text { thick } \\
\text { in the central part of the basin and } \\
\text { increases toward basin margins. }\end{array}$ & $\begin{array}{l}\text { Little evidence to support a } \\
\text { laterally extensive confining } \\
\text { layer. }\end{array}$ & $\begin{array}{l}\text { Downward near the basin } \\
\text { margins and upward in the dis- } \\
\text { charge area. Reversal occurs } \\
\text { seasonally in the southeastern } \\
\text { basin because of pumping. }\end{array}$ & $\begin{array}{l}\text { Less than } 0.03 \text { to } 30 \mathrm{ft} / \mathrm{d} \text { for the } \\
\text { upper } 330 \mathrm{ft} \text { of saturated basin } \\
\text { fill, with most of the central part } \\
\text { of the valley less than } 3 \mathrm{ft} / \mathrm{d} \text {. }\end{array}$ \\
\hline Truckee Meadows & $\begin{array}{l}\text { Northeast to north-central parts of } \\
\text { the basin (near the Truckee River) } \\
\text { have }<50 \mathrm{ft} \text { of unsaturated zone, } \\
\text { which becomes thicker to the } \\
\text { west and south. }\end{array}$ & $\begin{array}{l}\text { No continuous confining layer. } \\
\text { Finer-grained flood-plain } \\
\text { deposits are interbedded with } \\
\text { coarser-grained stream-chan- } \\
\text { nel deposits in the lower parts } \\
\text { of the basin. }\end{array}$ & $\begin{array}{l}\text { Downward near the basin } \\
\text { margins and upward in the } \\
\text { discharge area, mostly in the } \\
\text { northeastern part of the basin. } \\
\text { Downward near large pumping } \\
\text { centers. }\end{array}$ & $\begin{array}{l}\text { About } 12 \text { to } 28 \mathrm{ft} / \mathrm{d} \text { for basin- } \\
\text { fill material estimated from } \\
\text { pumping-test data. }\end{array}$ \\
\hline Upper Santa Cruz & $\begin{array}{l}\text { About } 5 \% \text { of the basin-fill aquifer } \\
\text { has depth to water less than } 50 \\
\mathrm{ft}, \text { mostly along and adjacent to } \\
\text { the Rillito River, Sapori Wash, } \\
\text { and southern reaches of the Santa } \\
\text { Cruz River. Depth to water is } \\
\text { greater than } 400 \mathrm{ft} \text { along the basin } \\
\text { margins in several areas. }\end{array}$ & No extensive confining layers. & $\begin{array}{l}\text { Downward in recharge areas } \\
\text { along basin margins, along } \\
\text { losing stream reaches, and in } \\
\text { areas with heavy pumping. } \\
\text { Upward in some areas along } \\
\text { the gaining reaches of the } \\
\text { Santa Cruz River. Davidson } \\
\text { (1973) notes some areas with } \\
\text { gravel or sand that have down- } \\
\text { ward gradients, and other area } \\
\text { with silt and clay that have } \\
\text { upward gradients. }\end{array}$ & $\begin{array}{l}\text { Values in the southern part of the } \\
\text { basin range from about } 0.3 \text { to } 3.0 \\
\mathrm{ft} / \mathrm{d} \text { for the Nogales Formation, } 1 \\
\text { to } 50 \mathrm{ft} / \mathrm{d} \text { for the older alluvium, } \\
\text { and } 100 \text { to } 600 \mathrm{ft} / \mathrm{d} \text { for the } \\
\text { younger alluvium. Values in } \\
\text { the northern part of the basin } \\
\text { range from } 1 \text { to } 50 \mathrm{ft} / \mathrm{d} \text { for the } \\
\text { Tinaja Beds, and } 20 \text { to } 100 \mathrm{ft} / \mathrm{d} \\
\text { for the overlaying Fort Lowel } \\
\text { Formation. }\end{array}$ \\
\hline $\begin{array}{l}\text { West Salt River } \\
\text { Valley }\end{array}$ & $\begin{array}{l}\text { About } 20 \% \text { of the basin-fill aquifer } \\
\text { has depth to water less than } 50 \\
\mathrm{ft} \text {, mostly along and adjacent to } \\
\text { the Salt and Gila Rivers. Depth } \\
\text { to water is greater than } 400 \mathrm{ft} \text { in } \\
\text { northern parts of the basin. }\end{array}$ & $\begin{array}{l}\text { Extensive silt and clay layers } \\
\text { form a confining bed near } \\
\text { Goodyear and also near } \\
\text { Glendale. }\end{array}$ & $\begin{array}{l}\text { Downward gradients occur in } \\
\text { many areas because of ground- } \\
\text { water pumping. Upward } \\
\text { gradients occur along parts of } \\
\text { the Gila River. }\end{array}$ & $\begin{array}{l}\text { Values range from } 6 \text { to } 14 \mathrm{ft} / \mathrm{d} \text { for } \\
\text { the lower part of the lower unit } \\
\text { of the basin fill, } 3 \text { to } 25 \mathrm{ft} / \mathrm{d} \text { for } \\
\text { the upper part of the lower unit, } \\
4 \text { to } 60 \mathrm{ft} / \mathrm{d} \text { for the middle unit, } \\
\text { and } 180 \text { to } 1,700 \mathrm{ft} / \mathrm{d} \text { for the } \\
\text { upper unit. }\end{array}$ \\
\hline
\end{tabular}




\section{How Redox Conditions are Determined}

Redox conditions present within an aquifer play an important role in groundwater quality, particularly in determining whether certain contaminants (including individual trace elements, anthropogenic compounds, or natural compounds) are capable of forming or persisting in groundwater. A variety of methods have been proposed in the scientific literature for determining a meaningful classification or value that can be assigned to represent aquifer redox conditions and their likely effect on elements or compounds of interest. However, many of these methods require specialized equipment and (or) provide results that are specific to only certain chemical processes. McMahon and Chapelle (2008) designed a framework that assigns redox conditions to generalized but widely useful categories based on the dissolved concentrations of specific redox-sensitive species commonly measured in regional assessments of groundwater quality conducted by NAWQA. The table shown here indicates the various parameters that are used to classify individual groundwater samples as oxic (generally where dissolved oxygen is present at a concentration of $0.5 \mathrm{mg} / \mathrm{L}$ or more), suboxic (generally where dissolved oxygen is less than $0.5 \mathrm{mg} / \mathrm{L}$ but no other parameters exceed specified thresholds), or anoxic (generally where dissolved oxygen is less than $0.5 \mathrm{mg} / \mathrm{L}$ and other parameters exceed specified thresholds). Where some characteristic of the aquifer and (or) sampled well results in mixing of groundwater from multiple flowpaths, "mixed" redox conditions can result, meaning that criteria for more than one redox classification are met.

Threshold concentrations for identifying redox processes in regional aquifer systems

\begin{tabular}{|c|c|c|c|c|c|c|}
\hline \multirow[b]{2}{*}{ Redox process } & \multicolumn{5}{|c|}{ Water quality criteria (milligrams per liter) } & \multirow[b]{2}{*}{ Comments } \\
\hline & $\mathbf{O}_{2}$ & $\mathrm{NO}_{3}^{-} \mathrm{N}$ & $\mathbf{M n}^{2+}$ & $\mathrm{Fe}^{2+}$ & $\mathrm{SO}_{4}^{2-}$ & \\
\hline \multicolumn{7}{|l|}{ Oxic } \\
\hline $\mathrm{O}_{2}$ reduction & $\geq 0.5$ & - & $<0.05$ & $<0.1$ & - & - \\
\hline \multicolumn{7}{|l|}{ Suboxic } \\
\hline- & $<0.5$ & $<0.5$ & $<0.05$ & $<0.1$ & - & Further definition of redox processes not possible \\
\hline \multicolumn{7}{|l|}{ Anoxic } \\
\hline $\mathrm{NO}_{3}^{-}$reduction & $<0.5$ & $\geq 0.5$ & $<0.05$ & $<0.1$ & - & - \\
\hline $\mathrm{Mn}(\mathrm{IV})$ reduction & $<0.5$ & $<0.5$ & $\geq 0.05$ & $<0.1$ & - & - \\
\hline $\mathrm{Fe}(\mathrm{III}) / \mathrm{SO}_{4}^{2-}$ reduction & $<0.5$ & $<0.5$ & - & $\geq 0.1$ & $\geq 0.5$ & - \\
\hline Methanogenesis & $<0.5$ & $<0.5$ & - & $\geq 0.1$ & $<0.5$ & - \\
\hline \multicolumn{7}{|l|}{ Mixed } \\
\hline - & - & - & - & - & - & Criteria for more than one redox process are met \\
\hline
\end{tabular}

(Zogorski and others, 2006). Redox conditions also affect the mobility of many naturally occurring trace elements, including arsenic and uranium. For example, arsenic tends to be more mobile in the primary form that it takes under anoxic conditions (arsenite) than in the form that it takes under oxic conditions (arsenate) because of differences in sorption characteristics. The sorption of trace elements such as arsenic onto aquifer materials is also $\mathrm{pH}$-dependent, with greater sorption of arsenate onto iron oxides occurring at $\mathrm{pH}$ values less than about 8.0, for example. Higher organic-carbon content within aquifer materials also can result in greater sorption of some contaminants, but the organic-carbon content of Southwestern basin-fill aquifers is generally low. Patterns in redox conditions and $\mathrm{pH}$ can be altered by human activities, including the addition of artificial recharge water (which is commonly oxic) and by groundwater withdrawals that cause transient dewatering, through which anoxic sediments can be exposed to the atmosphere and subsequently rewetted.

Conditions in the basin-fill aquifers of most of the 15 casestudy basins are generally oxic, particularly near the basin margin and in the upper part of the aquifer (table 8). However, anoxic conditions are relatively common at depth and near basin centers, particularly where fine-grained materials with higher organic-carbon contents are more likely to be present. This information is generally consistent with the analysis of McMahon and Chapelle (2008), who found that more than 85 percent of domestic wells in the Basin and Range and Central Valley principal aquifers were oxic. For most case-study 
basins, $\mathrm{pH}$ values generally appear to fall within a range of about 6.5 to 8.5 (table 8). In a few basins (particularly Carson Valley, Eagle Valley, Middle Rio Grande, and San Luis Valley), $\mathrm{pH}$ values exceed 8.0 across broad areas, which could result in larger groundwater concentrations of arsenic and possibly other trace elements as a result of desorption from sediments.

\section{Synthesis of Contaminant Occurrence and Major Factors Affecting Aquifer Vulnerability in Case-Study Basins}

Likely as a result of the general similarities among the 15 SWPA case-study basins in terms of physiographic setting, climate, and hydrogeology, certain groundwater contaminants are common to many of the basins. However, differences in important natural and human characteristics among the basins are reflected in observations of individual contaminants above levels of concern across broad areas of some basins but only small areas of other basins. These differences also are reflected in the sources and hydrogeologic controls that have been documented to affect the geographic areas (whether small or extensive) and aquifer depths where those contaminants are observed. In this section, on the basis of information presented for each case-study basin in Thiros and others (2010) and summarized in tables 9 through 11, observations of six relatively common groundwater contaminants and (or) contaminant classes are compared and contrasted among the basins. Individual contaminants (dissolved solids, nitrate, arsenic, and uranium) are discussed relative to a threshold concentration selected for reasons described below. Synthetic compounds in the contaminant classes of VOCs and pesticide compounds are discussed primarily in terms of mere presence or absence. See the text box, "Known Groundwater Contaminants in Southwestern Alluvial Basins" for information about additional contaminants not included in the analysis conducted for this report. Also, on the basis of information presented in Thiros and others (2010) and summarized in tables 9 through 11 , the most common natural and human sources of these contaminants among SWPA case-study basins are presented and discussed; as presented in this report, these sources can include the original source of the contaminant (such as a leaky storage tank containing VOCs) or a primary pathway by which the contaminant reaches the aquifer (such as through infiltration of wastewater containing VOCs). Also discussed are common hydrogeologic controls on where the contaminants are present. Given the range among the 15 case-study basins of the natural and human-related characteristics that have the

\section{Known Groundwater Contaminants in Southwestern Alluvial Basins}

Several groundwater contaminants have been detected across either small or large areas of Southwestern alluvial basins at levels of potential concern. The amount of information available on contaminant presence, concentration, and distribution varies widely by contaminant. In the interest of brevity, this report focuses on a total of just four contaminants (dissolved solids, nitrate, arsenic, and uranium) and two contaminant classes (VOCs and pesticide compounds) that represent a variety of potential natural and (or) anthropogenic sources, have been commonly detected at concentrations of potential concern, and have been studied thoroughly enough to allow some conclusions to be drawn about their prevalence and behavior in groundwater. Other groundwater contaminants that have been detected in Southwestern alluvial basins, but are not specifically addressed in the analysis presented in this report, include a variety of trace elements, radionuclides, microorganisms, and individual organic compounds. The presence of several such contaminants (listed in the table shown here) in water from domestic wells sampled in Southwestern alluvial basins is addressed in DeSimone (2009). Contaminants in the table were not chosen for inclusion in this report, generally, because of a low frequency of detection at levels of potential concern or a lack of regional data on presence and (or) behavior.

Contaminants previously detected in groundwater of Southwestern alluvial basins but not covered in the analysis presented in this report

\begin{tabular}{cccc}
\hline Minor or trace elements & Radionuclides & Microorganisms & Individual organic compounds \\
\hline Boron & Radon & Total coliform bacteria & Chloroform \\
Fluoride & Gross alpha-particle radioactivity & Escherichia coli bacteria & Methyl tert-butyl ether \\
Manganese & Gross beta-particle radioactivity & & Atrazine \\
Strontium & Radium-226 plus radium-228 & & Deethylatrazine \\
\hline
\end{tabular}


Table 8. Redox environments and pH ranges observed for groundwater in the 15 case-study basins in the Southwest Principal Aquifers study area.

[Unless otherwise noted, references for redox and pH information are listed in corresponding basin chapters in Thiros and others (2010). See the text box "How Redox Conditions are Determined" for definitions of redox terms and constituent thresholds used (unless otherwise indicated). Abbreviations: >, greater than; mg/L, milligrams per liter; NAWQA, National Water-Quality Assessment Program; ft, feet; Mn, manganese; Fe, iron; \%, percent]

\begin{tabular}{ccl}
\hline Basin & \multicolumn{1}{c}{ Estimated range of unsaturated-zone thickness } & \multicolumn{1}{c}{ Confining layers } \\
\hline Carson Valley & $\begin{array}{c}\text { Dissolved-oxygen concentrations were }>0.5 \mathrm{mg} / \mathrm{L} \text { in } 14 \text { of } 17 \text { wells } \\
\text { in the principal aquifer, mostly on the west side of the valley. }\end{array}$ & $\begin{array}{l}\mathrm{pH} \text { in } 31 \text { wells completed in the principal aquifer ranges from } 6.4 \\
\text { to } 9.1, \text { with } 6 \text { wells having pH }>8.0, \text { mostly on the west side of the } \\
\text { valley. }\end{array}$
\end{tabular}

Central Valley Groundwater in the coarser-grained alluvial-fan deposits on the eastern side of the valley is generally oxic, while in the finer grained basin and lake deposit areas near the axis of the valley it is usually anoxic.

Eagle Valley Dissolved-oxygen concentrations were $>0.5 \mathrm{mg} / \mathrm{L}$ in 15 of 22 wells in the principal aquifer, mostly on the west side of the valley.

Las Vegas Valley All 21 principal-aquifer wells had dissolved-oxygen concentrations greater than $0.5 \mathrm{mg} / \mathrm{L}$.

Middle Rio Generally oxic and (or) nitrate reducing except in about the upper

Grande

$300 \mathrm{ft}$ of aquifer within Rio Grande inner valley, where conditions are typically $\mathrm{Mn}$ and (or) Fe reducing; mixed redox conditions exist sporadically across the basin.

Salt Lake Valley Water near valley margins is generally oxic with redox conditions transitioning to anoxic near the valley center. The secondary recharge area is conceptualized as a transition zone between oxic and iron-reducing (anoxic) conditions (Stolp, 2007).

\begin{tabular}{|c|c|}
\hline San Jacinto & $\begin{array}{l}\text { Groundwater sampled by NAWQA in the San Jacinto Basin from } \\
\text { wells where the top of the well screen was deeper than a median } \\
\text { value of } 270 \mathrm{ft} \text { below land surface had a median dissolved-oxy- } \\
\text { gen concentration of } 0.5 \mathrm{mg} / \mathrm{L} \text { compared to wells with shallower } \\
\text { open intervals where the median dissolved-oxygen concentration } \\
\text { was } 5.8 \mathrm{mg} / \mathrm{L} \text {. }\end{array}$ \\
\hline
\end{tabular}

San Luis Valley Generally oxic and (or) nitrate reducing, with sporadic Mn reducing or mixed conditions; some methanogenesis, mainly in the center of the Alamosa Basin.

Santa Ana Dissolved-oxygen concentrations in water from 19 NAWQA Coastal sampled water-supply wells ranged from 0.3 to $4.4 \mathrm{mg} / \mathrm{L}$ with a median value of $1.8 \mathrm{mg} / \mathrm{L}$. Both concentrations less than 0.5 $\mathrm{mg} / \mathrm{L}$ were from the confined part of the aquifer.

Santa Ana Inland Oxic conditions were indicated by dissolved-oxygen concentrations in water sampled by NAWQA from 29 supply wells in the Inland Basin.The unconfined part of the Bunker Hill subbasin receives recharge from the mountain front and from the land surface resulting in oxic conditions. Lower dissolved-oxygen concentrations in downgradient monitoring wells in the confined part of the aquifer indicate anoxic conditions.

\begin{tabular}{|l|l|}
\hline $\begin{array}{l}\text { Sierra Vista Sub- } \\
\text { basin }\end{array}$ & $\begin{array}{r}1 \text { of } 19 \text { subunit survey samples }(5 \%) \text { had dissolved-oxygen concen- } \\
\text { trations less than } 0.5 \mathrm{mg} / \mathrm{L} .\end{array}$ \\
\hline $\begin{array}{l}\text { Spanish Springs } \\
\text { Valley }\end{array} \begin{array}{r}18 \text { of } 21 \text { public-supply wells had dissolved-oxygen concentrations } \\
>0.5 \mathrm{mg} / \mathrm{L} \text {, whereas } 7 \text { of } 7 \text { shallow wells had dissolved-oxygen } \\
\text { concentrations }>0.5 \mathrm{mg} / \mathrm{L} .\end{array}$
\end{tabular}

$\begin{aligned} & \text { Truckee Mead- } \\ & \text { ows }\end{aligned}$
$\begin{aligned} & \text { Dissolved-oxygen concentrations were }>0.5 \mathrm{mg} / \mathrm{L} \text { in } 16 \text { of } 17 \\ & \text { principal-aquifer wells. }\end{aligned}$

The median $\mathrm{pH}$ for groundwater sampled as part of the Central Valley NAWQA studies ranged from 7.1 to 7.4 standard units.

$\mathrm{pH}$ in 24 wells completed in the principal aquifer ranges from 6.6 to 8.5 , with 7 wells having $\mathrm{pH}>8.0$, mostly in the northern half of the basin.

22 water-supply wells completed in the principal aquifer had $\mathrm{pH}$ ranging from about 7.1 to 7.8 .

$\mathrm{pH}$ typically ranges from about 7.4 near the eastern mountain front to 8.2 west of the Rio Grande, where values exceed 8.0 across broad areas.

$\mathrm{pH}$ ranged from 7.0 to 8.0 with a median value of 7.4 in 50 water samples collected by NAWQA from the principal aquifer.

$\mathrm{pH}$ ranged from 6.7 to 8.9 with a median value of 7.6 in 23 water samples collected by NAWQA from the principal aquifer; 3 samples from relatively deep wells had $\mathrm{pH}$ greater than 8 .

$\mathrm{pH}$ typically ranges from about 7.2 in the northeastern Alamosa Basin to 8.3 in the basin center, where values commonly exceed 8 .

$\mathrm{pH}$ in water from 20 NAWQA sampled water-supply wells ranged from 6.9 to 8.7 with a median value of $7.6 \mathrm{mg} / \mathrm{L}$. The two $\mathrm{pH}$ values greater than 8.0 were from the confined part of the aquifer.

$\mathrm{pH}$ ranged from 6.9 to 7.8 with a median value of 7.5 in 29 water samples collected by NAWQA from the principal aquifer.

$80 \%$ of the subunit survey samples were greater than 7.2 , the 10 th percentile, and less than 7.9 , the 90th percentile.

$\mathrm{pH}$ in 22 wells completed in the principal aquifer ranges from 7.0 to 9.0 , with 5 wells having $\mathrm{pH}>8.0$, located in the central to southcentral parts of the basin.

$\mathrm{pH}$ in 17 wells completed in the principal aquifer ranges from 7.0 to 8.1 , with 1 well having $\mathrm{pH}>8.0$, located near the center of the valley.

$80 \%$ of the subunit survey samples were greater than 6.9 , the 10 th percentile, and less than 7.7, the 90th percentile.

$80 \%$ of the subunit survey samples were greater than 7.2 , the 10 th percentile, and less than 8.4 , the 90th percentile; values exceeding 8 occurred sporadically across the basin. 
Table 9. For each of the 15 case-study basins in the Southwest Principal Aquifers study area, locations where concentrations of $A$, dissolved solids, and $B$, nitrate, which have important natural and human sources, exceed specified thresholds in groundwater and associated sources and hydrogeologic controls.

[Unless otherwise noted, references for information presented here are listed in corresponding basin chapters in Thiros and others (2010). Abbreviations: GW, groundwater; DS, dissolved solids; $\mathrm{NO}_{3}$, nitrate; $\mathrm{mg} / \mathrm{L}$, milligrams per liter; ft, feet; ET, evapotranspiration; <, less than]

A. Dissolved solids, threshold concentration $500 \mathrm{mg} / \mathrm{L}$

\begin{tabular}{|c|c|c|c|c|c|}
\hline \multirow[b]{2}{*}{ Basin } & \multicolumn{2}{|c|}{ Location(s) within groundwater flow system } & \multicolumn{2}{|c|}{ Primary contaminant source(s) } & \multirow[b]{2}{*}{ Primary hydrogeologic control(s) } \\
\hline & $\begin{array}{l}\text { Areal location(s) where } \\
\text { DS exceeds } 500 \mathrm{mg} / \mathrm{L}\end{array}$ & $\begin{array}{l}\text { Vertical location(s) } \\
\text { where DS exceeds } \\
\quad 500 \mathrm{mg} / \mathrm{L}\end{array}$ & Natural source(s) & Human source(s) & \\
\hline \multirow[t]{2}{*}{ Carson Valley } & $\begin{array}{l}\text { Localized areas near } \\
\text { agricultural land use. }\end{array}$ & $\begin{array}{l}\text { Mostly shallow depths } \\
<50 \mathrm{ft} \text { deep. }\end{array}$ & No primary source. & $\begin{array}{l}\text { Agricultural irrigation } \\
\text { water infiltrating } \\
\text { through canals and (or) } \\
\text { fields; imported treated } \\
\text { municipal effluent } \\
\text { infiltrating through } \\
\text { streams, conveyance } \\
\text { channels, and irrigated } \\
\text { fields; wastewater leaking } \\
\text { from urban sewer pipes } \\
\text { and infiltrating from } \\
\text { septic systems. }\end{array}$ & $\begin{array}{l}\text { Presence of a shallow water table in areas with large } \\
\text { sources of potential artificial recharge; presence } \\
\text { of confining units inhibiting downward GW } \\
\text { movement to used part of aquifer. }\end{array}$ \\
\hline & Near thermal springs. & $\begin{array}{l}\text { Mostly shallow depths } \\
<50 \mathrm{ft} \text { deep. }\end{array}$ & $\begin{array}{l}\text { Saline water of } \\
\text { deep and (or) } \\
\text { geothermal origin. }\end{array}$ & None identified. & $\begin{array}{l}\text { Presence of faults or other structural features } \\
\text { enhancing upward movement of saline GW. }\end{array}$ \\
\hline \multirow[t]{2}{*}{ Central Valley } & $\begin{array}{l}\text { Broad areas mainly on } \\
\text { the western side of } \\
\text { basin. }\end{array}$ & Most or all depths. & $\begin{array}{l}\text { Natural recharge } \\
\text { water that } \\
\text { interacted with } \\
\text { rocks/sediments } \\
\text { prior to recharge; } \\
\text { rocks/sediments } \\
\text { contacted by GW } \\
\text { along flow paths } \\
\text { within the basin. }\end{array}$ & $\begin{array}{l}\text { Agricultural irrigation } \\
\text { water infiltrating through } \\
\text { canals and (or) fields; } \\
\text { wastewater infiltrating } \\
\text { from animal feedlots or } \\
\text { dairies. }\end{array}$ & $\begin{array}{l}\text { High ET of water during artificial recharge } \\
\text { processes; presence of reactive bedrock/sediments } \\
\text { in recharge areas; presence of reactive aquifer } \\
\text { sediments; application of artificial recharge } \\
\text { to areas of DS accumulation in the soil zone } \\
\text { over long periods of low recharge and high ET; } \\
\text { large sources of potential artificial recharge and } \\
\text { associated high modern recharge rates and young } \\
\text { GW ages; and high degree of modification of the } \\
\text { GW system (recharge and discharge), resulting in } \\
\text { increased flow rates and mixing. }\end{array}$ \\
\hline & $\begin{array}{l}\text { Discharge areas along } \\
\text { valley floor and in } \\
\text { southern part of basin. }\end{array}$ & Most or all depths. & $\begin{array}{l}\text { Natural recharge } \\
\text { water that } \\
\text { interacted with } \\
\text { rocks/sediments } \\
\text { prior to recharge; } \\
\text { rocks/sediments } \\
\text { contacted by GW } \\
\text { along flow paths } \\
\text { within the basin; } \\
\text { saline water of } \\
\text { deep and (or) } \\
\text { geothermal origin. }\end{array}$ & $\begin{array}{l}\text { Agricultural irrigation } \\
\text { water infiltrating through } \\
\text { canals and (or) fields; } \\
\text { wastewater infiltrating } \\
\text { from animal feedlots or } \\
\text { dairies. }\end{array}$ & $\begin{array}{l}\text { High ET of water during artificial recharge } \\
\text { processes; high ET of shallow GW in natural } \\
\text { discharge areas; presence of reactive bedrock/ } \\
\text { sediments in recharge areas; presence of reactive } \\
\text { aquifer sediments; application of artificial recharge } \\
\text { to areas of DS accumulation in the soil zone } \\
\text { over long periods of low recharge and high ET; } \\
\text { high degree of modification of the GW system } \\
\text { (recharge and discharge), resulting in increased } \\
\text { flow rates and mixing; presence of GW with very } \\
\text { long residence times; and presence of structural } \\
\text { features enhancing upward movement of saline } \\
\text { GW. }\end{array}$ \\
\hline Eagle Valley & $\begin{array}{l}\text { Western and central } \\
\text { areas of basin. }\end{array}$ & $\begin{array}{l}\text { Almost exclusively } \\
\text { shallow depths }<50 \mathrm{ft} \\
\text { deep. }\end{array}$ & $\begin{array}{l}\text { Natural recharge } \\
\text { water that } \\
\text { interacted with } \\
\text { rocks/sediments } \\
\text { prior to recharge. }\end{array}$ & $\begin{array}{l}\text { Municipal-supply water } \\
\text { infiltrating through } \\
\text { irrigated yards/turf } \\
\text { areas or leaking from } \\
\text { distribution pipes; } \\
\text { treated urban wastewater } \\
\text { infiltrating through } \\
\text { irrigated fields. }\end{array}$ & $\begin{array}{l}\text { Presence of discontinuous confining units inhibiting } \\
\text { downward GW movement; application of urban } \\
\text { recharge to areas of previous agricultural activity; } \\
\text { presence of reactive bedrock/sediments in } \\
\text { recharge areas. }\end{array}$ \\
\hline $\begin{array}{l}\text { Las Vegas } \\
\text { Valley }\end{array}$ & $\begin{array}{l}\text { Urban areas through- } \\
\text { out most of basin. }\end{array}$ & $\begin{array}{l}\text { Both shallow }(<50 \mathrm{ft} \\
\text { from land surface) } \\
\text { and deeper wells, } \\
\text { although higher } \\
\text { concentrations in } \\
\text { shallow wells. }\end{array}$ & $\begin{array}{l}\text { Natural recharge } \\
\text { water that } \\
\text { interacted with } \\
\text { rocks/sediments } \\
\text { prior to recharge. }\end{array}$ & $\begin{array}{l}\text { Engineered recharge of } \\
\text { treated Lake Mead water } \\
\text { through injection wells; } \\
\text { municipal-supply water } \\
\text { infiltrating through } \\
\text { irrigated yards/turf } \\
\text { areas or leaking from } \\
\text { distribution pipes. }\end{array}$ & $\begin{array}{l}\text { Presence of confining units inhibiting downward } \\
\text { GW movement; presence of a shallow water table } \\
\text { in areas with large sources of potential artificial } \\
\text { recharge; presence of reactive bedrock/sediments } \\
\text { in recharge areas. }\end{array}$ \\
\hline
\end{tabular}


Table 9. For each of the 15 case-study basins in the Southwest Principal Aquifers study area, locations where concentrations of $A$, dissolved solids, and $B$, nitrate, which have important natural and human sources, exceed specified thresholds in groundwater and associated sources and hydrogeologic controls.-Continued

\section{A. Dissolved solids, threshold concentration $500 \mathrm{mg} / \mathrm{L}$}

\begin{tabular}{|c|c|c|c|c|c|}
\hline \multirow[b]{2}{*}{ Basin } & \multicolumn{2}{|c|}{ Location(s) within groundwater flow system } & \multicolumn{2}{|c|}{ Primary contaminant source(s) } & \multirow[b]{2}{*}{ Primary hydrogeologic control(s) } \\
\hline & $\begin{array}{l}\text { Areal location(s) where } \\
\text { DS exceeds } 500 \mathrm{mg} / \mathrm{L}\end{array}$ & $\begin{array}{l}\text { Vertical location(s) } \\
\text { where DS exceeds } \\
\quad 500 \mathrm{mg} / \mathrm{L}\end{array}$ & Natural source(s) & Human source(s) & \\
\hline \multirow[t]{4}{*}{$\begin{array}{l}\text { Middle Rio } \\
\text { Grande }\end{array}$} & $\begin{array}{l}\text { Western and southern } \\
\text { basin margins. }\end{array}$ & Most or all depths. & $\begin{array}{l}\text { Natural recharge } \\
\text { water that } \\
\text { interacted with } \\
\text { rocks/sediments } \\
\text { prior to recharge. }\end{array}$ & None. & $\begin{array}{l}\text { Presence of reactive bedrock/sediments in recharge } \\
\text { areas; high ET of water during natural recharge } \\
\text { processes; natural mixing of high- and low-DS } \\
\text { GW of different origin; recharge by high-DS } \\
\text { subsurface inflow from adjacent basins. }\end{array}$ \\
\hline & $\begin{array}{l}\text { Localized parts of the } \\
\text { Rio Grande inner } \\
\text { valley. }\end{array}$ & $\begin{array}{l}\text { Depths generally } \\
<100 \mathrm{ft} \text {. }\end{array}$ & $\begin{array}{l}\text { Natural recharge } \\
\text { water that } \\
\text { interacted with } \\
\text { rocks/sediments } \\
\text { prior to recharge. }\end{array}$ & $\begin{array}{l}\text { Agricultural irrigation } \\
\text { water infiltrating through } \\
\text { canals and (or) fields; } \\
\text { wastewater infiltrating } \\
\text { from septic systems; } \\
\text { possibly municipal- } \\
\text { supply water infiltrating } \\
\text { through irrigated yards/ } \\
\text { turf areas or leaking from } \\
\text { distribution pipes. }\end{array}$ & $\begin{array}{l}\text { High ET of water during natural and artificial } \\
\text { recharge processes; high ET of shallow GW in } \\
\text { natural discharge areas; presence of a shallow } \\
\text { water table in areas with large sources of potential } \\
\text { artificial recharge; high degree of modification of } \\
\text { the GW system (recharge and discharge), resulting } \\
\text { in increased flow rates and mixing; possible } \\
\text { application of artificial recharge to areas of DS } \\
\text { accumulation in the soil zone over long periods of } \\
\text { low recharge and high ET. }\end{array}$ \\
\hline & $\begin{array}{l}\text { Localized areas } \\
\text { observed in the } \\
\text { northern, central, } \\
\text { and eastern parts of } \\
\text { the basin (both basin } \\
\text { margins and valley } \\
\text { floor). }\end{array}$ & Most or all depths. & $\begin{array}{l}\text { Saline water of } \\
\text { deep and (or) } \\
\text { geothermal origin. }\end{array}$ & None. & $\begin{array}{l}\text { Presence of faults or other structural features } \\
\text { enhancing upward movement of saline GW. }\end{array}$ \\
\hline & $\begin{array}{l}\text { Broad areas in the } \\
\text { southern (downgra- } \\
\text { dient) part of the } \\
\text { basin. }\end{array}$ & Most or all depths. & $\begin{array}{l}\text { Saline water of } \\
\text { deep and (or) } \\
\text { geothermal origin. }\end{array}$ & None. & $\begin{array}{l}\text { Presence of structural features enhancing upward } \\
\text { movement of saline GW. }\end{array}$ \\
\hline \multirow[t]{3}{*}{$\begin{array}{l}\text { Salt Lake } \\
\text { Valley }\end{array}$} & $\begin{array}{l}\text { Much of valley except } \\
\text { for the southeast } \\
\text { part that receives } \\
\text { recharge from non- } \\
\text { reactive rocks. }\end{array}$ & $\begin{array}{l}\text { Main used part of } \\
\text { aquifer. }\end{array}$ & $\begin{array}{l}\text { Natural recharge } \\
\text { water that } \\
\text { interacted with } \\
\text { rocks/sediments } \\
\text { prior to recharge; } \\
\text { rocks/sediments } \\
\text { contacted by GW } \\
\text { along flow paths } \\
\text { within the basin. }\end{array}$ & $\begin{array}{l}\text { Agricultural irrigation } \\
\text { water infiltrating through } \\
\text { canals and (or) fields; } \\
\text { urban runoff (including } \\
\text { dissolved road salt) } \\
\text { infiltrating as diffuse } \\
\text { recharge. }\end{array}$ & $\begin{array}{l}\text { Presence of reactive bedrock/sediments in } \\
\text { recharge area; presence of reactive aquifer } \\
\text { sediments; large sources of potential artificial } \\
\text { recharge and associated high modern recharge } \\
\text { rates and young GW ages; pumping-enhanced } \\
\text { downward and (or) horizontal movement of } \\
\text { high-DS GW. }\end{array}$ \\
\hline & $\begin{array}{l}\text { Localized areas in } \\
\text { western, northwest- } \\
\text { ern, and southern } \\
\text { part of Salt Lake } \\
\text { Valley. }\end{array}$ & $\begin{array}{l}\text { Deeper parts of } \\
\text { aquifer including } \\
\text { Tertiary sediments. }\end{array}$ & $\begin{array}{l}\text { Rocks/sediments } \\
\text { contacted by GW } \\
\text { along flow paths } \\
\text { within the basin; } \\
\text { saline water of } \\
\text { deep and (or) } \\
\text { geothermal } \\
\text { origin. }\end{array}$ & None identified. & $\begin{array}{l}\text { Presence of reactive aquifer sediments; presence } \\
\text { of faults or other structural features enhancing } \\
\text { upward movement of saline GW; presence of } \\
\text { GW with very long residence times. }\end{array}$ \\
\hline & $\begin{array}{l}\text { Much of valley except } \\
\text { for the southeastern } \\
\text { part that receives } \\
\text { recharge from non- } \\
\text { reactive rocks. }\end{array}$ & $\begin{array}{l}\text { Shallow part of } \\
\text { aquifer in most of } \\
\text { valley except for } \\
\text { upgradient of canals } \\
\text { on east side. }\end{array}$ & $\begin{array}{l}\text { Natural recharge } \\
\text { water that } \\
\text { interacted with } \\
\text { rocks/sediments } \\
\text { prior to recharge; } \\
\text { rocks/sediments } \\
\text { contacted by GW } \\
\text { along flow paths } \\
\text { within the basin. }\end{array}$ & $\begin{array}{l}\text { Agricultural irrigation } \\
\text { water infiltrating through } \\
\text { canals and (or) fields; } \\
\text { urban runoff (including } \\
\text { dissolved road salt) } \\
\text { and irrigation water } \\
\text { infiltrating as diffuse } \\
\text { recharge. }\end{array}$ & $\begin{array}{l}\text { Presence of reactive bedrock/sediments in } \\
\text { recharge area; presence of reactive aquifer } \\
\text { sediments; high ET of shallow GW in natural } \\
\text { discharge areas; large sources of potential } \\
\text { artificial recharge and associated high modern } \\
\text { recharge rates and young GW ages; presence } \\
\text { of confining units that inhibit downward } \\
\text { groundwater movement. }\end{array}$ \\
\hline San Jacinto & $\begin{array}{l}\text { Most of the basin } \\
\text { except for the } \\
\text { southeastern part } \\
\text { that receives runoff } \\
\text { from the San Jacinto } \\
\text { Mountains. }\end{array}$ & Most or all depths. & $\begin{array}{l}\text { Rocks/sediments } \\
\text { contacted by GW } \\
\text { along flow paths } \\
\text { within the basin. }\end{array}$ & $\begin{array}{l}\text { Agricultural irrigation } \\
\text { water infiltrating through } \\
\text { canals and (or) fields; } \\
\text { imported river water } \\
\text { infiltrating through } \\
\text { streams, conveyance } \\
\text { channels, and (or) } \\
\text { irrigated fields. }\end{array}$ & $\begin{array}{l}\text { High ET of water during natural and artificial } \\
\text { recharge processes; high ET of shallow GW in } \\
\text { natural discharge areas; presence of reactive } \\
\text { aquifer sediments. }\end{array}$ \\
\hline
\end{tabular}


Table 9. For each of the 15 case-study basins in the Southwest Principal Aquifers study area, locations where concentrations of $A$, dissolved solids, and $B$, nitrate, which have important natural and human sources, exceed specified thresholds in groundwater and associated sources and hydrogeologic controls.-Continued

\section{A. Dissolved solids, threshold concentration $500 \mathrm{mg} / \mathrm{L}$}

\begin{tabular}{|c|c|c|c|c|c|}
\hline \multirow[b]{2}{*}{ Basin } & \multicolumn{2}{|c|}{ Location(s) within groundwater flow system } & \multicolumn{2}{|c|}{ Primary contaminant source(s) } & \multirow[b]{2}{*}{ Primary hydrogeologic control(s) } \\
\hline & $\begin{array}{l}\text { Areal location(s) where } \\
\text { DS exceeds } 500 \mathrm{mg} / \mathrm{L}\end{array}$ & $\begin{array}{l}\text { Vertical location(s) } \\
\text { where DS exceeds } \\
\quad 500 \mathrm{mg} / \mathrm{L}\end{array}$ & Natural source(s) & Human source(s) & \\
\hline \multirow[t]{2}{*}{$\begin{array}{l}\text { San Luis } \\
\text { Valley }\end{array}$} & $\begin{array}{l}\text { Ancestral sump area } \\
\text { of the valley floor in } \\
\text { the Alamosa Basin. }\end{array}$ & $\begin{array}{l}\text { Not well defined } \\
\text { for greater depths, } \\
\text { but perhaps depths } \\
\text { generally }<250 \mathrm{ft} .\end{array}$ & $\begin{array}{l}\text { Rocks/sediments } \\
\text { contacted by GW } \\
\text { along flow paths } \\
\text { within the basin. }\end{array}$ & $\begin{array}{l}\text { Agricultural irrigation } \\
\text { water infiltrating through } \\
\text { canals and (or) fields. }\end{array}$ & $\begin{array}{l}\text { High ET of shallow GW in natural discharge } \\
\text { areas; presence of GW redox and (or) } \mathrm{pH} \\
\text { conditions conducive to mineral dissolution. }\end{array}$ \\
\hline & $\begin{array}{l}\text { Localized parts of } \\
\text { agricultural areas in } \\
\text { the San Luis closed } \\
\text { basin (both basin } \\
\text { margins and valley } \\
\text { floor outside ances- } \\
\text { tral sump area). }\end{array}$ & $\begin{array}{l}\text { Depths generally } \\
<120 \mathrm{ft} \text { and above } \\
\text { the confining unit. }\end{array}$ & $\begin{array}{l}\text { No primary } \\
\text { source. }\end{array}$ & $\begin{array}{l}\text { Agricultural irrigation } \\
\text { water infiltrating through } \\
\text { canals and (or) fields. }\end{array}$ & $\begin{array}{l}\text { High ET of water during artificial recharge } \\
\text { processes; presence of a shallow water table in } \\
\text { areas with large sources of potential artificial } \\
\text { recharge; large sources of potential artificial } \\
\text { recharge and associated high modern recharge } \\
\text { rates and young GW ages; presence of confining } \\
\text { units and natural hydraulic gradients inhibiting } \\
\text { downward GW movement. }\end{array}$ \\
\hline \multirow[t]{3}{*}{$\begin{array}{l}\text { Santa Ana } \\
\text { Coastal }\end{array}$} & $\begin{array}{l}\text { Eastern and southern } \\
\text { margins of basin. }\end{array}$ & Most or all depths. & $\begin{array}{l}\text { Natural recharge } \\
\text { water that } \\
\text { interacted with } \\
\text { rocks/sediments } \\
\text { prior to recharge; } \\
\text { rocks/sediments } \\
\text { contacted by GW } \\
\text { along flow paths } \\
\text { within the basin. }\end{array}$ & $\begin{array}{l}\text { Engineered recharge of } \\
\text { urban runoff, imported } \\
\text { river water, and (or) } \\
\text { treated wastewater } \\
\text { through impoundments } \\
\text { and spreading facilities. }\end{array}$ & $\begin{array}{l}\text { Presence of reactive bedrock/sediments in } \\
\text { recharge areas; presence of reactive aquifer } \\
\text { sediments; large sources of potential artificial } \\
\text { recharge and associated high modern recharge } \\
\text { rates and young GW ages; high degree of } \\
\text { modification of the GW system (recharge and } \\
\text { discharge), resulting in increased flow rates and } \\
\text { mixing. }\end{array}$ \\
\hline & $\begin{array}{l}\text { Western margin of } \\
\text { basin. }\end{array}$ & Most or all depths. & $\begin{array}{l}\text { Saline water of } \\
\text { marine origin. }\end{array}$ & None. & $\begin{array}{l}\text { Seawater intrusion as a result of GW pumping } \\
\text { near coastal areas. }\end{array}$ \\
\hline & $\begin{array}{l}\text { Pressure area (con- } \\
\text { fined part) of basin. }\end{array}$ & $\begin{array}{l}\text { Shallow depths above } \\
\text { confining layer. }\end{array}$ & $\begin{array}{l}\text { Saline water of } \\
\text { marine origin. }\end{array}$ & $\begin{array}{l}\text { Municipal-supply water } \\
\text { infiltrating through } \\
\text { irrigated yards/turf } \\
\text { areas or leaking from } \\
\text { distribution pipes. }\end{array}$ & $\begin{array}{l}\text { High ET of water during natural and artificial } \\
\text { recharge processes; high ET of shallow GW } \\
\text { in natural discharge areas; seawater intrusion } \\
\text { as a result of GW pumping near coastal areas; } \\
\text { presence of confining units that inhibit downward } \\
\text { groundwater movement. }\end{array}$ \\
\hline \multirow[t]{2}{*}{$\begin{array}{l}\text { Santa Ana } \\
\text { Inland }\end{array}$} & $\begin{array}{l}\text { Riverside, Arlington, } \\
\text { Temescal, and south- } \\
\text { ern part of Chino } \\
\text { subbasins (downgra- } \\
\text { dient part of Santa } \\
\text { Ana Inland Basin } \\
\text { along the Santa Ana } \\
\text { River). }\end{array}$ & Most or all depths. & $\begin{array}{l}\text { Rocks/sediments } \\
\text { contacted by GW } \\
\text { along flow paths } \\
\text { within the basin. }\end{array}$ & $\begin{array}{l}\text { Agricultural irrigation } \\
\text { water infiltrating through } \\
\text { canals and (or) fields; } \\
\text { engineered recharge of } \\
\text { treated wastewater and } \\
\text { imported river water } \\
\text { through impoundments } \\
\text { and spreading facilities; } \\
\text { wastewater infiltrating } \\
\text { from animal feedlots or } \\
\text { dairies. }\end{array}$ & $\begin{array}{l}\text { High ET of water during natural and artificial } \\
\text { recharge processes; high ET of shallow GW in } \\
\text { natural discharge areas; presence of reactive } \\
\text { aquifer sediments; presence of a shallow water } \\
\text { table in areas with large sources of potential } \\
\text { artificial recharge. }\end{array}$ \\
\hline & $\begin{array}{l}\text { Southern part of } \\
\text { Chino subbasin } \\
\text { (downgradient part } \\
\text { of Santa Ana Inland } \\
\text { Basin). }\end{array}$ & $\begin{array}{l}\text { Mostly shallow } \\
\text { depths (between } \\
\text { land surface and } \\
\text { first major confining } \\
\text { layer). }\end{array}$ & $\begin{array}{l}\text { Rocks/sediments } \\
\text { contacted by GW } \\
\text { along flow paths } \\
\text { within the basin. }\end{array}$ & $\begin{array}{l}\text { Agricultural irrigation } \\
\text { water infiltrating through } \\
\text { canals and (or) fields; } \\
\text { wastewater infiltrating } \\
\text { from animal feedlots or } \\
\text { dairies. }\end{array}$ & $\begin{array}{l}\text { High ET of water during natural and artificial } \\
\text { recharge processes; high ET of shallow GW in } \\
\text { natural discharge areas; presence of reactive } \\
\text { aquifer sediments; presence of a shallow water } \\
\text { table in areas with large sources of potential } \\
\text { artificial recharge. }\end{array}$ \\
\hline $\begin{array}{l}\text { Sierra Vista } \\
\text { Subbasin }\end{array}$ & $\begin{array}{l}\text { Localized part of the } \\
\text { basin between the } \\
\text { Whetstone Moun- } \\
\text { tains and the San } \\
\text { Pedro River. } 37 \text { of } \\
39 \text { wells distributed } \\
\text { across the basin had } \\
\text { DS below } 500 \mathrm{mg} / \mathrm{L} \text {. }\end{array}$ & Not defined. & $\begin{array}{l}\text { Natural recharge } \\
\text { that interacted } \\
\text { with deposits of } \\
\text { gypsum interbed- } \\
\text { ded with siltstone } \\
\text { and dolomite in } \\
\text { the Whetstone } \\
\text { mountains prior } \\
\text { to recharge. }\end{array}$ & None identified. & $\begin{array}{l}\text { Presence of reactive bedrock/sediments (gypsum) } \\
\text { in recharge areas. }\end{array}$ \\
\hline
\end{tabular}


Table 9. For each of the 15 case-study basins in the Southwest Principal Aquifers study area, locations where concentrations of $A$, dissolved solids, and $B$, nitrate, which have important natural and human sources, exceed specified thresholds in groundwater and associated sources and hydrogeologic controls.-Continued

\section{A. Dissolved solids, threshold concentration $500 \mathrm{mg} / \mathrm{L}$}

\begin{tabular}{|c|c|c|c|c|c|}
\hline \multirow[b]{2}{*}{ Basin } & \multicolumn{2}{|c|}{ Location(s) within groundwater flow system } & \multicolumn{2}{|c|}{ Primary contaminant source(s) } & \multirow[b]{2}{*}{ Primary hydrogeologic control(s) } \\
\hline & $\begin{array}{l}\text { Areal location(s) where } \\
\text { DS exceeds } 500 \mathrm{mg} / \mathrm{L}\end{array}$ & $\begin{array}{l}\text { Vertical location(s) } \\
\text { where DS exceeds } \\
\quad 500 \mathrm{mg} / \mathrm{L}\end{array}$ & Natural source(s) & Human source(s) & \\
\hline $\begin{array}{l}\text { Spanish } \\
\text { Springs } \\
\text { Valley }\end{array}$ & $\begin{array}{l}\text { Very southern part of } \\
\text { basin near Orr Ditch } \\
\text { and North Truckee } \\
\text { Drain. }\end{array}$ & $\begin{array}{l}\text { Mostly greater than } \\
150 \mathrm{ft} \text { from land } \\
\text { suface. }\end{array}$ & $\begin{array}{l}\text { Natural recharge } \\
\text { water that inter- } \\
\text { acted with rocks/ } \\
\text { sediments prior } \\
\text { to recharge. }\end{array}$ & $\begin{array}{l}\text { Imported river water } \\
\text { infiltrating through } \\
\text { streams and (or) } \\
\text { conveyance channels; } \\
\text { (imported) agricultural } \\
\text { irrigation water } \\
\text { infiltrating through } \\
\text { canals and (or) fields. }\end{array}$ & $\begin{array}{l}\text { High ET of water during artificial recharge } \\
\text { processes; large sources of potential artificial } \\
\text { recharge and associated high modern recharge } \\
\text { rates and young GW ages; presence of reactive } \\
\text { bedrock/sediments in recharge areas. }\end{array}$ \\
\hline \multirow[t]{2}{*}{$\begin{array}{l}\text { Truckee } \\
\text { Meadows }\end{array}$} & Northern half of basin & $\begin{array}{l}\text { Mostly shallow } \\
\text { depths }\end{array}$ & $\begin{array}{l}\text { Natural recharge } \\
\text { water that inter- } \\
\text { acted with rocks/ } \\
\text { sediments prior } \\
\text { to recharge }\end{array}$ & $\begin{array}{l}\text { Wastewater leaking from } \\
\text { urban sewer pipes or } \\
\text { infiltrating from septic } \\
\text { systems }\end{array}$ & $\begin{array}{l}\text { High ET of shallow GW in natural discharge } \\
\text { areas; application of urban recharge to areas of } \\
\text { previous agricultural activity }\end{array}$ \\
\hline & $\begin{array}{l}\text { Near Steamboat Hills } \\
\text { geothermal area to } \\
\text { the south. }\end{array}$ & $\begin{array}{l}\text { Mostly shallow } \\
\text { depths. }\end{array}$ & $\begin{array}{l}\text { Saline water of } \\
\text { deep and (or) } \\
\text { geothermal } \\
\text { origin. }\end{array}$ & None identified. & $\begin{array}{l}\text { Presence of faults or other structural features } \\
\text { enhancing upward movement of saline GW. }\end{array}$ \\
\hline \multirow[t]{2}{*}{$\begin{array}{l}\text { Upper Santa } \\
\text { Cruz }\end{array}$} & $\begin{array}{l}\text { Localized parts of } \\
\text { basin within about } \\
1.25 \text { miles of major } \\
\text { faults in basin-fill } \\
\text { sediments. }\end{array}$ & Not defined & $\begin{array}{l}\text { Gypsiferous sedi- } \\
\text { ments contacted } \\
\text { by groundwater } \\
\text { along flow paths } \\
\text { within the basin; } \\
\text { saline water of } \\
\text { deep origin. }\end{array}$ & None identified. & $\begin{array}{l}\text { Presence of reactive materials (gypsum) along } \\
\text { groundwater flow paths in basin-fill aquifer; } \\
\text { presence of low hydraulically conductive } \\
\text { sediments uplifted by faulting that inhibit } \\
\text { lateral flow and promote upward groundwater } \\
\text { movement. }\end{array}$ \\
\hline & Vail to central Tucson. & Not defined. & $\begin{array}{l}\text { Gypsiferous sedi- } \\
\text { ments contacted } \\
\text { by groundwater } \\
\text { along flow paths } \\
\text { within the basin. }\end{array}$ & None identified. & $\begin{array}{l}\text { Presence of reactive materials (gypsum) along } \\
\text { groundwater flow paths in basin-fill aquifer. }\end{array}$ \\
\hline \multirow[t]{2}{*}{$\begin{array}{l}\text { West Salt } \\
\text { River Valley }\end{array}$} & $\begin{array}{l}\text { Areas adjacent to } \\
\text { and downgradient } \\
\text { from the Luke Salt } \\
\text { Body, especially } \\
\text { those areas south of } \\
\text { Interstate } 10 .\end{array}$ & Most or all depths. & $\begin{array}{l}\text { A halite body and } \\
\text { bedded evapo- } \\
\text { rites in the basin- } \\
\text { fill sediments. }\end{array}$ & None identified. & $\begin{array}{l}\text { Presence of reactive materials (halite, gypsum, } \\
\text { and other evaporites) in saturated basin-fill } \\
\text { sediments. }\end{array}$ \\
\hline & Agricultural areas. & $\begin{array}{l}\text { Most or all depths, } \\
\text { but especially the } \\
\text { top } 10 \mathrm{ft} \text { of the } \\
\text { aquifer. }\end{array}$ & $\begin{array}{l}\text { No primary } \\
\text { source. }\end{array}$ & $\begin{array}{l}\text { Agricultural irrigation } \\
\text { water infiltrating through } \\
\text { canals and (or) fields; } \\
\text { wastewater infiltrating } \\
\text { from animal feedlots or } \\
\text { dairies. }\end{array}$ & $\begin{array}{l}\text { High ET of water during artificial recharge } \\
\text { processes; presence of confining units that inhibit } \\
\text { downward groundwater movement, especially } \\
\text { near Buckeye. }\end{array}$ \\
\hline
\end{tabular}


Table 9. For each of the 15 case-study basins in the Southwest Principal Aquifers study area, locations where concentrations of $A$, dissolved solids, and $B$, nitrate, which have important natural and human sources, exceed specified thresholds in groundwater and associated sources and hydrogeologic controls.-Continued

\section{B. Nitrate, threshold concentration $5 \mathrm{mg} / \mathrm{L}$}

\begin{tabular}{|c|c|c|c|c|c|}
\hline \multirow[b]{2}{*}{ Basin } & \multicolumn{2}{|c|}{ Location(s) within groundwater flow system } & \multicolumn{2}{|c|}{ Primary contaminant source(s) } & \multirow[b]{2}{*}{ Primary hydrogeologic control(s) } \\
\hline & $\begin{array}{l}\text { Areal location(s) where } \\
\mathrm{NO}_{3} \text { exceeds } 5 \mathrm{mg} / \mathrm{L}\end{array}$ & $\begin{array}{c}\text { Vertical location(s) } \\
\text { where } \mathrm{NO}_{3} \text { exceeds } \\
5 \mathrm{mg} / \mathrm{L}\end{array}$ & Natural source(s) & Human source(s) & \\
\hline Carson Valley & $\begin{array}{l}\text { No concentrations } \\
\text { exceeding } 5 \mathrm{mg} / \mathrm{L} \\
\text { have been } \\
\text { documented. }\end{array}$ & Not applicable. & Not applicable. & Not applicable. & None identified. \\
\hline Central Valley & $\begin{array}{l}\text { Broad areas mainly on } \\
\text { the eastern side of the } \\
\text { basin. }\end{array}$ & $\begin{array}{l}\text { More prevalent in } \\
\text { shallower parts of the } \\
\text { aquifer system. }\end{array}$ & None identified. & $\begin{array}{l}\text { Agricultural irrigation } \\
\text { water infiltrating } \\
\text { through fertilized fields, } \\
\text { wastewater infiltrating } \\
\text { from animal feedlots } \\
\text { or dairies; wastewater } \\
\text { leaking from urban sewer } \\
\text { pipes or infiltrating from } \\
\text { septic systems; municipal- } \\
\text { supply water infiltrating } \\
\text { through fertilized yards/ } \\
\text { turf areas; urban runoff } \\
\text { infiltrating through } \\
\text { streams and (or) as diffuse } \\
\text { recharge. }\end{array}$ & $\begin{array}{l}\text { Presence of oxic GW conditions conducive to } \mathrm{NO}_{3} \\
\text { formation and (or) persistence; large sources of } \\
\text { potential artificial recharge and associated high } \\
\text { modern recharge rates and young GW ages; } \\
\text { high degree of modification of the GW system } \\
\text { (recharge and discharge) resulting in increased } \\
\text { flow rates and mixing; application of urban } \\
\text { recharge to areas of previous agricultural activity. }\end{array}$ \\
\hline
\end{tabular}

\begin{tabular}{|c|c|c|c|c|c|}
\hline Eagle Valley & $\begin{array}{l}\text { Localized areas mostly } \\
\text { in the central part of } \\
\text { the basin, also to the } \\
\text { south. }\end{array}$ & $\begin{array}{l}\text { Mostly shallow parts } \\
\text { of the aquifer }<100 \mathrm{ft} \\
\text { from land surface. }\end{array}$ & None identified. & $\begin{array}{l}\text { Wastewater leaking from } \\
\text { urban sewer pipes and } \\
\text { (or) infiltrating from } \\
\text { septic systems; municipal- } \\
\text { supply water infiltrating } \\
\text { through fertilized yards; } \\
\text { treated urban wastewater } \\
\text { infiltrating through } \\
\text { irrigated golf courses. }\end{array}$ & $\begin{array}{l}\text { Application of urban recharge to areas of previous } \\
\text { agricultural activity; presence of natural hydraulic } \\
\text { gradients inhibiting downward GW movement; } \\
\text { presence of oxic GW conditions conducive to } \mathrm{NO}_{3} \\
\text { persistence. }\end{array}$ \\
\hline $\begin{array}{l}\text { Las Vegas } \\
\text { Valley }\end{array}$ & $\begin{array}{l}\text { Localized parts of } \\
\text { central, urban valley } \\
\text { floor areas. }\end{array}$ & $\begin{array}{l}\text { Shallow part of aquifer } \\
<85 \mathrm{ft} \text { from land } \\
\text { surface. }\end{array}$ & None identified. & $\begin{array}{l}\text { Municipal-supply water } \\
\text { infiltrating through } \\
\text { fertilized yards/turf areas; } \\
\text { engineered recharge of } \\
\text { urban runoff and treated } \\
\text { wastewater through } \\
\text { injection wells. }\end{array}$ & $\begin{array}{l}\text { Presence of confining units inhibiting downward } \\
\text { GW movement; high degree of modification of the } \\
\text { GW system (recharge and discharge), resulting in } \\
\text { increased flow rates and mixing; presence of oxic } \\
\text { GW conditions conducive to } \mathrm{NO}_{3} \text { persistence. }\end{array}$ \\
\hline
\end{tabular}

\begin{tabular}{|c|c|c|c|c|c|}
\hline $\begin{array}{l}\text { Middle Rio } \\
\text { Grande }\end{array}$ & $\begin{array}{l}\text { Localized parts of the } \\
\text { northwest area of the } \\
\text { basin (primarily near } \\
\text { basin margins). }\end{array}$ & $\begin{array}{l}\text { Not well defined, } \\
\text { but depths perhaps } \\
\text { extending a few } \\
\text { hundred } \mathrm{ft} \text { below } \\
\text { the water table. }\end{array}$ & $\begin{array}{l}\text { Likely natural } \\
\text { recharge water } \\
\text { containing } \mathrm{NO}_{3} \\
\text { from precipitation } \\
\text { or soil-zone } \\
\text { accumulation over } \\
\text { long periods of } \\
\text { low recharge and } \\
\text { high ET. }\end{array}$ & None. & $\begin{array}{l}\text { High ET of water during natural recharge processes; } \\
\text { presence of oxic GW conditions conducive to } \mathrm{NO}_{3} \\
\text { persistence. }\end{array}$ \\
\hline & $\begin{array}{l}\text { Localized parts of the } \\
\text { Rio Grande inner } \\
\text { valley. }\end{array}$ & $\begin{array}{l}\text { Depths generally } \\
<100 \mathrm{ft} \text {. }\end{array}$ & None identified. & $\begin{array}{l}\text { Agricultural irrigation } \\
\text { water infiltrating } \\
\text { through fertilized fields; } \\
\text { wastewater infiltrating } \\
\text { from septic systems. }\end{array}$ & $\begin{array}{l}\text { High ET of water during natural and artificial } \\
\text { recharge processes; high ET of shallow GW in } \\
\text { natural discharge areas; presence of a shallow } \\
\text { water table in areas with large sources of potential } \\
\text { artificial recharge; high degree of modification of } \\
\text { the GW system (recharge and discharge), resulting } \\
\text { in increased flow rates and mixing. }\end{array}$ \\
\hline $\begin{array}{l}\text { Salt Lake } \\
\text { Valley }\end{array}$ & $\begin{array}{l}\text { Broad areas of the } \\
\text { valley with recent } \\
\text { residential land use. }\end{array}$ & $\begin{array}{l}\text { Shallow part of } \\
\text { aquifer system. }\end{array}$ & None identified. & $\begin{array}{l}\text { Agricultural irrigation } \\
\text { water infiltrating } \\
\text { through fertilized fields; } \\
\text { municipal-supply water } \\
\text { infiltrating through } \\
\text { fertilized yards/turf areas; } \\
\text { wastewater infiltrating } \\
\text { from animal feedlots } \\
\text { or dairies; wastewater } \\
\text { leaking from urban sewer } \\
\text { pipes or infiltrating from } \\
\text { septic systems; urban } \\
\text { runoff infiltrating through } \\
\text { streams and (or) as diffuse } \\
\text { recharge. }\end{array}$ & $\begin{array}{l}\text { Presence of oxic GW conditions conducive to } \mathrm{NO}_{3} \\
\text { formation and (or) persistence; large sources of } \\
\text { potential artificial recharge and associated high } \\
\text { modern recharge rates and young GW ages; } \\
\text { application of urban recharge to areas of previous } \\
\text { agricultural activity; presence of confining units } \\
\text { that inhibit downward groundwater movement. }\end{array}$ \\
\hline
\end{tabular}


Table 9. For each of the 15 case-study basins in the Southwest Principal Aquifers study area, locations where concentrations of $A$, dissolved solids, and $B$, nitrate, which have important natural and human sources, exceed specified thresholds in groundwater and associated sources and hydrogeologic controls.-Continued

\section{$B$. Nitrate, threshold concentration $5 \mathrm{mg} / \mathrm{L}$}

\begin{tabular}{|c|c|c|c|c|c|}
\hline \multirow[b]{2}{*}{ Basin } & \multicolumn{2}{|c|}{ Location(s) within groundwater flow system } & \multicolumn{2}{|c|}{ Primary contaminant source(s) } & \multirow[b]{2}{*}{ Primary hydrogeologic control(s) } \\
\hline & $\begin{array}{l}\text { Areal location(s) where } \\
\mathrm{NO}_{3} \text { exceeds } 5 \mathrm{mg} / \mathrm{L}\end{array}$ & $\begin{array}{l}\text { Vertical location(s) } \\
\text { where } \mathrm{NO}_{3} \text { exceeds } \\
\qquad 5 \mathrm{mg} / \mathrm{L}\end{array}$ & Natural source(s) & Human source(s) & \\
\hline San Jacinto & $\begin{array}{l}\text { Localized areas, both } \\
\text { along the basin } \\
\text { margin and in basin } \\
\text { floor areas. }\end{array}$ & $\begin{array}{l}\text { More prevalent in } \\
\text { shallower parts of } \\
\text { the aquifer system. }\end{array}$ & None identified. & $\begin{array}{l}\text { Agricultural irrigation } \\
\text { water infiltrating } \\
\text { through fertilized fields; } \\
\text { wastewater infiltrating } \\
\text { from animal feedlots } \\
\text { or dairies; wastewater } \\
\text { leaking from urban sewer } \\
\text { pipes or infiltrating from } \\
\text { septic systems; municipal- } \\
\text { supply water infiltrating } \\
\text { through fertilized yards/ } \\
\text { turf areas; treated urban } \\
\text { wastewater infiltrating } \\
\text { through irrigated } \\
\text { fields and (or) through } \\
\text { impoundments. }\end{array}$ & $\begin{array}{l}\text { Presence of oxic GW conditions conducive to } \mathrm{NO}_{3} \\
\text { formation and (or) persistence; large sources of } \\
\text { potential artificial recharge and associated high } \\
\text { modern recharge rates and young GW ages. }\end{array}$ \\
\hline $\begin{array}{l}\text { San Luis } \\
\text { Valley }\end{array}$ & $\begin{array}{l}\text { Agricultural areas } \\
\text { both within and } \\
\text { south of the San } \\
\text { Luis closed basin } \\
\text { (both basin margins } \\
\text { and valley floor). }\end{array}$ & $\begin{array}{l}\text { Depths generally } \\
<120 \mathrm{ft} \text { and above } \\
\text { the confining unit. }\end{array}$ & None identified. & $\begin{array}{l}\text { Agricultural irrigation } \\
\text { water infiltrating through } \\
\text { fertilized fields. }\end{array}$ & $\begin{array}{l}\text { High ET of water during artificial recharge } \\
\text { processes; presence of a shallow water table in } \\
\text { areas with large sources of potential artificial } \\
\text { recharge; large sources of potential artificial } \\
\text { recharge and associated high modern recharge } \\
\text { rates and young GW ages; presence of confining } \\
\text { units and natural hydraulic gradients inhibiting } \\
\text { downward GW movement; presence of oxic GW } \\
\text { conditions conducive to } \mathrm{NO}_{3} \text { formation and (or) } \\
\text { persistence in large areas. }\end{array}$ \\
\hline $\begin{array}{l}\text { Santa Ana } \\
\text { Coastal }\end{array}$ & $\begin{array}{l}\text { Broad areas, mainly in } \\
\text { the } 1 / 3 \text { of the basin } \\
\text { where unconfined } \\
\text { conditions exist. }\end{array}$ & $\begin{array}{l}\text { More prevalent in } \\
\text { shallower parts of } \\
\text { the aquifer system. }\end{array}$ & None identified. & $\begin{array}{l}\text { Agricultural irrigation } \\
\text { water infiltrating } \\
\text { through fertilized fields; } \\
\text { engineered recharge of } \\
\text { urban runoff or treated } \\
\text { wastewater through } \\
\text { impoundments and } \\
\text { spreading facilities; } \\
\text { wastewater leaking from } \\
\text { urban sewer pipes or } \\
\text { infiltrating from septic } \\
\text { systems; municipal- } \\
\text { supply water infiltrating } \\
\text { through fertilized yards/ } \\
\text { turf areas; urban runoff } \\
\text { infiltrating through } \\
\text { streams and (or) as diffuse } \\
\text { recharge. }\end{array}$ & $\begin{array}{l}\text { Presence of oxic GW conditions conducive to } \mathrm{NO}_{3} \\
\text { formation and (or) persistence; large sources of } \\
\text { potential artificial recharge and associated high } \\
\text { modern recharge rates and young GW ages; } \\
\text { high degree of modification of the GW system } \\
\text { (recharge and discharge), resulting in increased } \\
\text { flow rates and mixing; application of urban } \\
\text { recharge to areas of previous agricultural activity; } \\
\text { presence of confining units that inhibit downward } \\
\text { groundwater movement. }\end{array}$ \\
\hline \multirow[t]{2}{*}{$\begin{array}{l}\text { Santa Ana } \\
\text { Inland }\end{array}$} & $\begin{array}{l}\text { Much of basin, both } \\
\text { along the basin } \\
\text { margin and in basin } \\
\text { floor areas. }\end{array}$ & $\begin{array}{l}\text { More prevalent in } \\
\text { shallower parts of } \\
\text { the aquifer system. }\end{array}$ & None identified. & $\begin{array}{l}\text { Agricultural irrigation } \\
\text { water infiltrating } \\
\text { through fertilized fields; } \\
\text { wastewater infiltrating } \\
\text { from animal feedlots } \\
\text { or dairies; wastewater } \\
\text { leaking from urban sewer } \\
\text { pipes or infiltrating from } \\
\text { septic systems; municipal- } \\
\text { supply water infiltrating } \\
\text { through fertilized yards/ } \\
\text { turf areas; treated urban } \\
\text { wastewater infiltrating } \\
\text { through irrigated fields. }\end{array}$ & $\begin{array}{l}\text { Presence of oxic GW conditions conducive to } \\
\mathrm{NO}_{3} \text { formation and (or) persistence; presence of } \\
\text { a shallow water table in areas with large sources } \\
\text { of potential artificial recharge; large sources of } \\
\text { potential artificial recharge and associated high } \\
\text { modern recharge rates and young GW ages. }\end{array}$ \\
\hline & $\begin{array}{l}\text { Southern part of } \\
\text { Chino subbasin } \\
\text { (downgradient part } \\
\text { of Santa Ana Inland } \\
\text { Basin). }\end{array}$ & $\begin{array}{l}\text { Mostly shallow } \\
\text { depths (between } \\
\text { land surface and } \\
\text { first major confining } \\
\text { layer). }\end{array}$ & None identified. & $\begin{array}{l}\text { Agricultural irrigation } \\
\text { water infiltrating } \\
\text { through fertilized fields; } \\
\text { wastewater infiltrating } \\
\text { from animal feedlots or } \\
\text { dairies. }\end{array}$ & $\begin{array}{l}\text { Presence of oxic GW conditions conducive to } \\
\mathrm{NO}_{3} \text { formation and (or) persistence; presence of } \\
\text { a shallow water table in areas with large sources } \\
\text { of potential artificial recharge; large sources of } \\
\text { potential artificial recharge and associated high } \\
\text { modern recharge rates and young GW ages. }\end{array}$ \\
\hline
\end{tabular}


Table 9. For each of the 15 case-study basins in the Southwest Principal Aquifers study area, locations where concentrations of $A$, dissolved solids, and $B$, nitrate, which have important natural and human sources, exceed specified thresholds in groundwater and associated sources and hydrogeologic controls.-Continued

\section{B. Nitrate, threshold concentration $5 \mathrm{mg} / \mathrm{L}$}

\begin{tabular}{|c|c|c|c|c|c|}
\hline \multirow[b]{2}{*}{ Basin } & \multicolumn{2}{|c|}{ Location(s) within groundwater flow system } & \multicolumn{2}{|c|}{ Primary contaminant source(s) } & \multirow[b]{2}{*}{ Primary hydrogeologic control(s) } \\
\hline & $\begin{array}{l}\text { Areal location(s) where } \\
\mathrm{NO}_{3} \text { exceeds } 5 \mathrm{mg} / \mathrm{L}\end{array}$ & $\begin{array}{c}\text { Vertical location(s) } \\
\text { where } \mathrm{NO}_{3} \text { exceeds } \\
5 \mathrm{mg} / \mathrm{L}\end{array}$ & Natural source(s) & Human source(s) & \\
\hline $\begin{array}{l}\text { Sierra Vista } \\
\text { subbasin }\end{array}$ & $\begin{array}{l}\text { Very localized; only } \\
2 \text { of } 39 \text { wells ( } 5 \\
\text { percent) distributed } \\
\text { across the basin ex- } \\
\text { ceeded } 5 \mathrm{mg} / \mathrm{L} \text {. }\end{array}$ & Not assessed. & None identified. & None identified. & $\begin{array}{l}\text { Presence of oxic GW conditions conducive to } \mathrm{NO}_{3} \\
\text { persistence. }\end{array}$ \\
\hline $\begin{array}{l}\text { Spanish } \\
\text { Springs Valley }\end{array}$ & $\begin{array}{l}\text { Near urban areas; } 17 \\
\text { of } 19 \text { shallow wells } \\
\text { exceeded } 5 \mathrm{mg} / \mathrm{L} .\end{array}$ & $\begin{array}{l}\text { Generally less than } \\
120 \mathrm{ft} \text { from land } \\
\text { surface. }\end{array}$ & $\begin{array}{l}\text { Natural recharge } \\
\text { water containing } \\
\mathrm{NO}_{3} \text { from an } \\
\text { unidentified } \\
\text { but likely } \\
\text { natural source } \\
\text { (precipitation, } \\
\text { soil-zone } \\
\text { accumulation, and } \\
\text { (or) vegetation). }\end{array}$ & $\begin{array}{l}\text { Wastewater leaking } \\
\text { from urban sewer } \\
\text { pipes or infiltrating } \\
\text { from septic systems; } \\
\text { agricultural irrigation } \\
\text { water infiltrating through } \\
\text { fertilized fields. }\end{array}$ & $\begin{array}{l}\text { High ET of water during artificial recharge } \\
\text { processes; high degree of modification of the } \\
\text { GW system (recharge and discharge), resulting in } \\
\text { increased flow rates and mixing; presence of oxic } \\
\text { GW conditions conducive to } \mathrm{NO}_{3} \text { persistence. }\end{array}$ \\
\hline $\begin{array}{l}\text { Truckee } \\
\text { Meadows }\end{array}$ & $\begin{array}{l}\text { Localized areas } \\
\text { mostly in the south. }\end{array}$ & $\begin{array}{l}\text { Shallow part of } \\
\text { aquifer, }<50 \mathrm{ft} \text { from } \\
\text { land surface. }\end{array}$ & $\begin{array}{l}\text { Nitrogen fixation by } \\
\text { bacteria associated } \\
\text { with desert } \\
\text { legumes. }\end{array}$ & $\begin{array}{l}\text { Wastewater leaking from } \\
\text { urban sewer pipes or } \\
\text { infiltrating from septic } \\
\text { systems; treated urban } \\
\text { wastewater infiltrating } \\
\text { through irrigated fields; } \\
\text { agricultural irrigation } \\
\text { water infiltrating through } \\
\text { fertilized fields. }\end{array}$ & $\begin{array}{l}\text { Presence of oxic GW conditions conducive to } \mathrm{NO}_{3} \\
\text { persistence. }\end{array}$ \\
\hline $\begin{array}{l}\text { Upper Santa } \\
\text { Cruz }\end{array}$ & $\begin{array}{l}\text { Localized parts of the } \\
\text { basin; } 8 \text { of } 58 \text { wells } \\
\text { (14 percent) distrib- } \\
\text { uted across the basin } \\
\text { exceeded } 5 \mathrm{mg} / \mathrm{L} .\end{array}$ & Not assessed. & None identified. & $\begin{array}{l}\text { Sources have not been } \\
\text { determined definitively; } \\
\text { however, potential urban } \\
\text { sources of recently } \\
\text { recharged water include } \\
\text { treated effluent, septic } \\
\text { system seepage, urban } \\
\text { irrigation containing } \\
\text { household fertilizers, } \\
\text { and infiltration of urban } \\
\text { runoff. }\end{array}$ & $\begin{array}{l}\text { Possible presence of preferential flow paths of } \\
\text { unknown origin; presence of oxic GW conditions } \\
\text { conducive to } \mathrm{NO}_{3} \text { persistence; may include } \\
\text { application of urban recharge to areas of previous } \\
\text { agricultural activity. }\end{array}$ \\
\hline \multirow[t]{2}{*}{$\begin{array}{l}\text { West Salt } \\
\text { River Valley }\end{array}$} & $\begin{array}{l}\text { Local, undeveloped } \\
\text { parts of the basin, } \\
\text { especially the north- } \\
\text { ern part. }\end{array}$ & Not assessed. & $\begin{array}{l}\text { Natural recharge } \\
\text { water containing } \\
\text { nitrate from an } \\
\text { unidentified } \\
\text { but likely } \\
\text { natural source } \\
\text { (precipitation, } \\
\text { soil-zone } \\
\text { accumulation, and } \\
\text { (or) vegetation). }\end{array}$ & None identified. & $\begin{array}{l}\text { Presence of oxic GW conditions conducive to } \mathrm{NO}_{3} \\
\text { persistence. }\end{array}$ \\
\hline & $\begin{array}{l}\text { Broad areas in devel- } \\
\text { oped parts of the } \\
\text { basin, especially the } \\
\text { southern part. }\end{array}$ & $\begin{array}{l}\text { Most depths of the } \\
\text { aquifer. }\end{array}$ & None identified. & $\begin{array}{l}\text { Agricultural irrigation } \\
\text { water infiltrating through } \\
\text { canals and (or) fertilized } \\
\text { fields; municipal-supply } \\
\text { water infiltrating through } \\
\text { fertilized yards/turf areas; } \\
\text { wastewater infiltrating } \\
\text { from animal feedlots } \\
\text { or dairies; urban runoff } \\
\text { infiltrating through } \\
\text { streams, through dry } \\
\text { wells, and (or) as diffuse } \\
\text { recharge; treated urban } \\
\text { wastewater infiltrating } \\
\text { from streams or through } \\
\text { irrigated fields. }\end{array}$ & $\begin{array}{l}\text { Large sources of potential artificial recharge and } \\
\text { associated high modern recharge rates and young } \\
\text { groundwater ages; high ET of water during } \\
\text { artificial recharge processes; application of urban } \\
\text { recharge in areas of previous agricultural activity. }\end{array}$ \\
\hline
\end{tabular}


Table 9. For each of the 15 case-study basins in the Southwest Principal Aquifers study area, locations where concentrations of $A$, dissolved solids, and $B$, nitrate, which have important natural and human sources, exceed specified thresholds in groundwater and associated sources and hydrogeologic controls.-Continued

\section{B. Nitrate, threshold concentration $5 \mathrm{mg} / \mathrm{L}$}

\begin{tabular}{|c|c|c|c|c|c|}
\hline \multirow[b]{2}{*}{ Basin } & \multicolumn{2}{|c|}{ Location(s) within groundwater flow system } & \multicolumn{2}{|c|}{ Primary contaminant source(s) } & \multirow[b]{2}{*}{ Primary hydrogeologic control(s) } \\
\hline & $\begin{array}{l}\text { Areal location(s) where } \\
\mathrm{NO}_{3} \text { exceeds } 5 \mathrm{mg} / \mathrm{L}\end{array}$ & $\begin{array}{c}\text { Vertical location(s) } \\
\text { where } \mathrm{NO}_{3} \text { exceeds } \\
5 \mathrm{mg} / \mathrm{L}\end{array}$ & Natural source(s) & Human source(s) & \\
\hline
\end{tabular}

greatest potential to affect aquifer vulnerability (as described in the previous section of this report), conclusions reached about important sources of and controls on groundwater contaminants in aquifers of these basins are believed to be generally representative of sources and controls in basin-fill aquifers across the Southwest.

Although the focus of the following discussion is on areas where the contaminants of interest have been detected in groundwater and on sources and factors that have contributed to the presence of those contaminants, the importance of the lack of contaminant detection in other areas where studies have been conducted should not be diminished. Areas where contaminant sources and (or) factors contributing to groundwater contamination are not present can be quite extensive in many basins and represent areas where land and water resources can still be managed to help prevent groundwater contamination from occurring.

\section{Contaminants with Important Natural and Human Sources}

\section{Dissolved Solids}

The dissolved-solids concentration of a water sample is a measure of the total amount of material that has dissolved in the water, both inorganic and organic. Examples of natural processes that can increase dissolved-solids concentrations are mineral dissolution and evapotranspiration. Human sources of dissolved solids to groundwater include septic-tank effluent and excess irrigation water. As described in detail in Anning and others (2007), the dissolved-solids concentration of water is a major determinant of its appropriate uses (such as for crop irrigation or drinking water). For this discussion, a concentration of $500 \mathrm{mg} / \mathrm{L}$ was selected as the threshold above which dissolved-solids concentrations could be of concern. This threshold is equivalent to the USEPA secondary (non-enforceable) standard for dissolved solids in drinking water, which is based on concerns related to potential cosmetic or aesthetic effects rather than health effects. For each of the 15 case-study basins, the locations in the basin-fill aquifer where dissolvedsolids concentrations exceed $500 \mathrm{mg} / \mathrm{L}$ are described in table 9; the sources of and important hydrogeologic controls on dissolved-solids concentrations exceeding $500 \mathrm{mg} / \mathrm{L}$ also are described.

Dissolved-solids concentrations are known to exceed $500 \mathrm{mg} / \mathrm{L}$ in at least some part of the basin-fill aquifer in all 15 case-study basins and across broad areas of the basin-fill aquifer in 11 case-study basins (all but the Carson Valley, Sierra Vista subbasin, Spanish Springs Valley, and Upper Santa Cruz) (table 9A). In four basins (Carson Valley, Eagle Valley, San Luis Valley, and Truckee Meadows), studies suggest that elevated dissolved-solids concentrations are present primarily in shallow groundwater not used for drinking. In nine casestudy basins distributed across the SWPA study area, concentrations exceeding $500 \mathrm{mg} / \mathrm{L}$ have been documented at most or all aquifer depths.

In all case-study basins, at least one primary source of dissolved solids resulting in concentrations greater than $500 \mathrm{mg} / \mathrm{L}$ is of natural origin. A natural source of primary importance in nine basins (Central Valley, Eagle Valley, Las Vegas Valley, Middle Rio Grande, Salt Lake Valley, Santa Ana Coastal, Sierra Vista subbasin, Spanish Springs Valley, and Truckee Meadows) is recharge water that interacted with rocks or sediments prior to natural recharge to the aquifer; in most cases, this rock-water interaction probably occurred outside the boundary of the alluvial basin. Seven of these basins (all but Spanish Springs Valley and Truckee Meadows) are among the eight with sedimentary and carbonate rocks together covering at least 20 percent of the surrounding hydrogeologic area (fig. 3), and the median percentage of surrounding sedimentary plus carbonate rocks for the basins as a group is significantly higher than the median percentage for the other basins at the 95-percent probability level (fig. 16). In eight basins (Central Valley, Salt Lake Valley, San Jacinto, San Luis Valley, Santa Ana Coastal, Santa Ana Inland, Upper Santa Cruz, and West Salt River Valley), a natural source of primary importance is the sediments (or rocks) contacted by groundwater along flow paths within the basin's 
aquifer. In Arizona, for example, halite and gypsum deposits within the basin have a substantial effect on dissolved-solids concentrations. Saline water of deep and (or) geothermal origin also increases the concentrations of dissolved solids in groundwater in six basins (Carson Valley, Central Valley, Middle Rio Grande, Salt Lake Valley, Truckee Meadows, and Upper Santa Cruz).

In all six case-study basins with at least 14 percent agricultural land use (fig. 17), infiltration of agricultural irrigation water through fields and (or) canals is listed as a primary human source contributing to elevated dissolved-solids concentrations in groundwater. In two (Middle Rio Grande and Santa Ana Inland) of the three basins where agricultural irrigation water is listed as a primary contributor to elevated dissolved-solids concentrations despite having less than 10 percent agricultural land use, the presence of a shallow water table in areas where substantial quantities of artificial recharge (including agricultural irrigation water) are applied is listed as an important hydrogeologic control. Wastewater infiltrating from animal feedlots and (or) dairies is another agricultural source of elevated dissolved-solids concentrations, listed as a primary source for three basins. In total, at least one contaminant source associated with agricultural land use is listed as a primary source of dissolved solids in nine case-study basins (fig. 17).
Urban recharge sources (including municipal-supply water infiltrating through irrigated yards/turf areas or from distribution pipes, urban runoff infiltrating as diffuse recharge, wastewater infiltrating from septic/sewer systems, treated urban wastewater infiltrating through irrigated fields, and (or) engineered recharge of various types) are listed as primary contributors to elevated dissolved-solids concentrations in groundwater in eight basins, five of which have at least 52 percent urban land use (fig. 17). The individual urban recharge source most commonly contributing to elevated dissolvedsolids concentrations is infiltrating municipal-supply water (table 9A), which can increase in solute concentration during infiltration as a result of evapotranspiration or of flushing of dissolved solids that had previously built up in the unsaturated zone. In five of the eight basins with important urban sources (including two of the three basins with relatively small areas of urban land use), engineered recharge or use of urban wastewater for irrigation is listed as a contributor.

The primary hydrogeologic controls on the locations and depths where dissolved-solids concentrations exceed $500 \mathrm{mg} / \mathrm{L}$ in the basin-fill aquifers of the 15 case-study basins include natural and human-related processes/characteristics. Natural controls of importance in concentrating dissolved solids include high rates of evapotranspiration of shallow groundwater in natural discharge areas and high rates of evapotranspiration during recharge of natural and artificial recharge water. In the
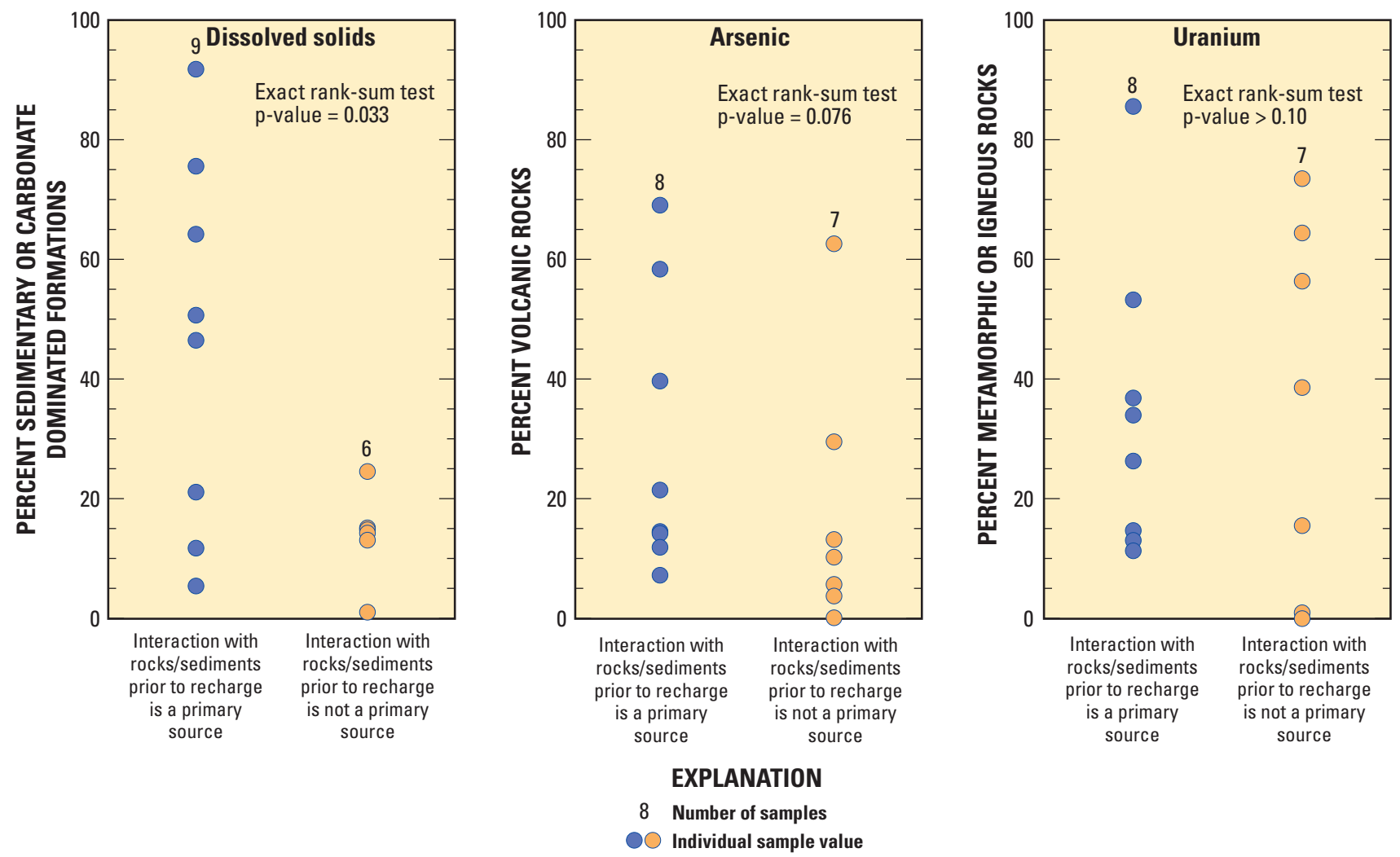

Figure 16. Comparison of selected categories of generalized geology surrounding the 15 case-study basins in the Southwest Principal Aquifers study area for basins where interaction with rocks or sediments prior to recharge is and is not a primary source of $A$, dissolved solids, $B$, arsenic, or $C$, uranium to groundwater. 

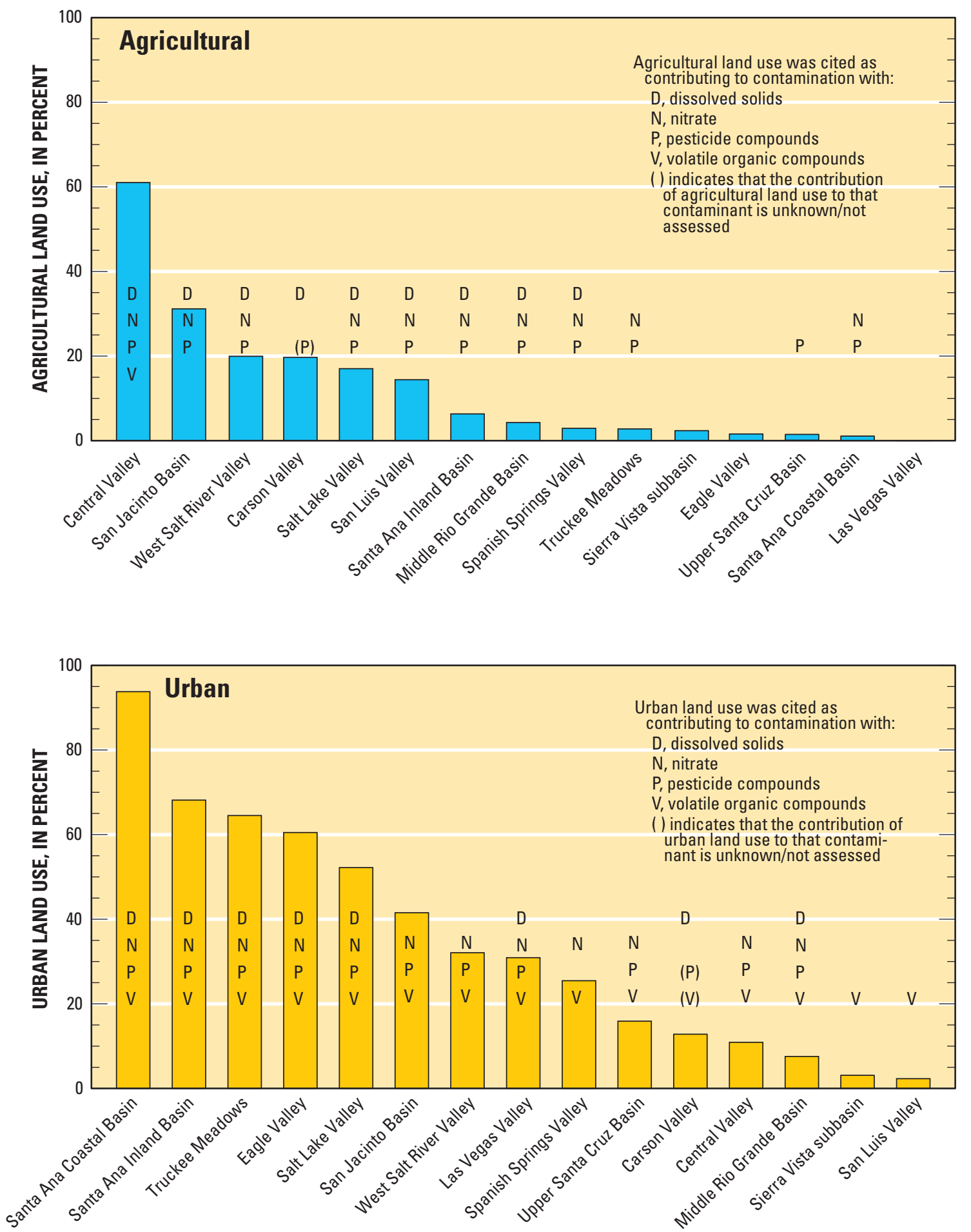

Figure 17. Comparison of the case-study basins in the Southwest Principal Aquifers study area where $A$, agricultural or $B$, urban land use was cited as a primary contributor to groundwater contamination with respect to contaminants with human sources. 
six basins where deep and (or) geothermal water is a source of elevated dissolved solids, structural controls including faults acting as conduits and (or) the presence of bedrock highs enhance upward movement of deep and (or) geothermal water into shallower parts of the aquifer. Another natural control important to the distribution of elevated dissolved-solids concentrations in seven basins (Carson Valley, Eagle Valley, Las Vegas Valley, Salt Lake Valley, San Luis Valley, Santa Ana Coastal, and West Salt River Valley) is the presence of natural confining units and (or) upward hydraulic gradients that help to protect the deeper aquifer used for domestic or public supply from contamination that is present in the shallower aquifer.

Human-related controls of importance in contributing to the distribution of elevated dissolved-solids concentrations in groundwater include the establishment of large sources of artificial recharge (resulting in increased modern recharge rates and younger overall groundwater ages) and the substantial modification of groundwater systems with respect to both recharge and discharge processes (resulting in increased groundwater flow rates and mixing). Case-study basins where large sources of artificial recharge and high degrees of system modification are cited as contributing factors are the Central Valley, Middle Rio Grande, San Luis Valley, Spanish Springs Valley, and Santa Ana Coastal, all of which have had recharge more than double between predevelopment and modern conditions (fig. 18).

Overall, findings from the 15 case-study basins suggest that elevated dissolved-solids concentrations commonly limit the use of untreated groundwater for drinking water (and perhaps other uses) in Southwestern alluvial basins. In the majority of basins (13), sources associated with natural and human-related processes/characteristics have been documented to contribute to the distribution of elevated dissolved-solids concentrations. The natural interaction of water with rocks and sediments in recharge areas has been cited as an important source with slightly greater frequency than the natural interaction of water with rocks and sediments within the aquifer. Agricultural and urban recharge sources also have been cited as important with nearly equal frequency and have been noted to contribute appreciably to elevated dissolved-solids concentrations even in basins where the individual land use of interest accounts for only a small fraction of land use in the basin as a whole. Extensive modifications of the hydrologic system primarily for either agricultural or urban purposes have influenced the distribution of elevated dissolved-solids concentrations in a few basins. Natural hydrogeologic controls are occasionally cited as providing some measure of protection to the aquifer (particularly confining units and (or) natural upward gradients that protect greater aquifer depths) but are more commonly cited as contributing to elevated dissolvedsolids concentrations.

\section{Nitrate}

Nitrate is the nutrient most frequently detected in groundwater in Southwestern alluvial basins and is a relatively common groundwater contaminant. Natural sources of nitrate can be present in the unsaturated zone (Bohlke and others, 1997; Walvoord and others, 2003; Graham and others, 2008) and consequently in groundwater. Human sources of nitrate include fertilizers applied to irrigated fields, runoff from animal feedlots, and septic-tank effluent. The USEPA primary (healthbased) drinking-water standard for nitrate is $10 \mathrm{mg} / \mathrm{L}$ because of the potential for elevated nitrate to restrict oxygen transport in the blood of infants (U.S. Environmental Protection Agency, 2009). For this discussion, a concentration of $5 \mathrm{mg} / \mathrm{L}$ was selected as the threshold above which nitrate could be of concern. This threshold is substantially higher than the upper bound estimate of $1 \mathrm{mg} / \mathrm{L}$ for relative background concentration of nitrate in shallow, recently recharged groundwaters of the conterminous United States as determined by Nolan and Hitt (2003) for areas mostly unaffected by agriculture and urban land. Therefore, the selected threshold of $5 \mathrm{mg} / \mathrm{L}$ is indicative of groundwater that has likely been affected by elevated nitrate inputs, even though concentrations have not reached standards established for the protection of human health.

Nitrate concentrations are known to exceed $5 \mathrm{mg} / \mathrm{L}$ in at least some part of the basin-fill aquifer in 14 case-study basins and across broad areas of the basin-fill aquifer in 6 basins (Central Valley, San Jacinto, San Luis Valley, Santa Ana Inland, Spanish Springs Valley, and West Salt River Valley) (table 9B). In only one basin, the West Salt River Valley, do studies suggest that elevated nitrate concentrations commonly extend beyond shallow depths of the aquifer.

In four case-study basins (Middle Rio Grande, Spanish Springs Valley, Truckee Meadows, and West Salt River Valley), at least one primary source of nitrate resulting in concentrations greater than $5 \mathrm{mg} / \mathrm{L}$ is of natural origin. Although the exact origins of natural nitrate in groundwater generally have not been studied in most basins, they are believed to include flushing of soil-zone or subsoil accumulations of nitrate. In areas where recharge through the soil profile is minimal over long periods, such accumulations can result from evapotranspiration of precipitation or nitrification of ammonium produced by nitrogen-fixing organisms usually associated with leguminous plants (Walvoord and others, 2003; Graham and others, 2008). In at least one basin (the Middle Rio Grande), evidence for elevated nitrate resulting merely from evapotranspiration of natural recharge (without subsequent denitrification) has been documented.

In five of the six case-study basins with at least 14 percent agricultural land use (fig. 17), infiltration of agricultural irrigation water through fertilized fields is listed as a primary human source contributing to elevated nitrate in groundwater. In five additional basins, agricultural irrigation water is listed as a primary contributor to elevated nitrate despite only about 1 to 6 percent of land use being agricultural. Wastewater infiltrating from animal feedlots and (or) dairies is another agricultural source of elevated nitrate concentrations that is listed as a primary source for five basins. In total, at least one contaminant source associated with agricultural land use is 

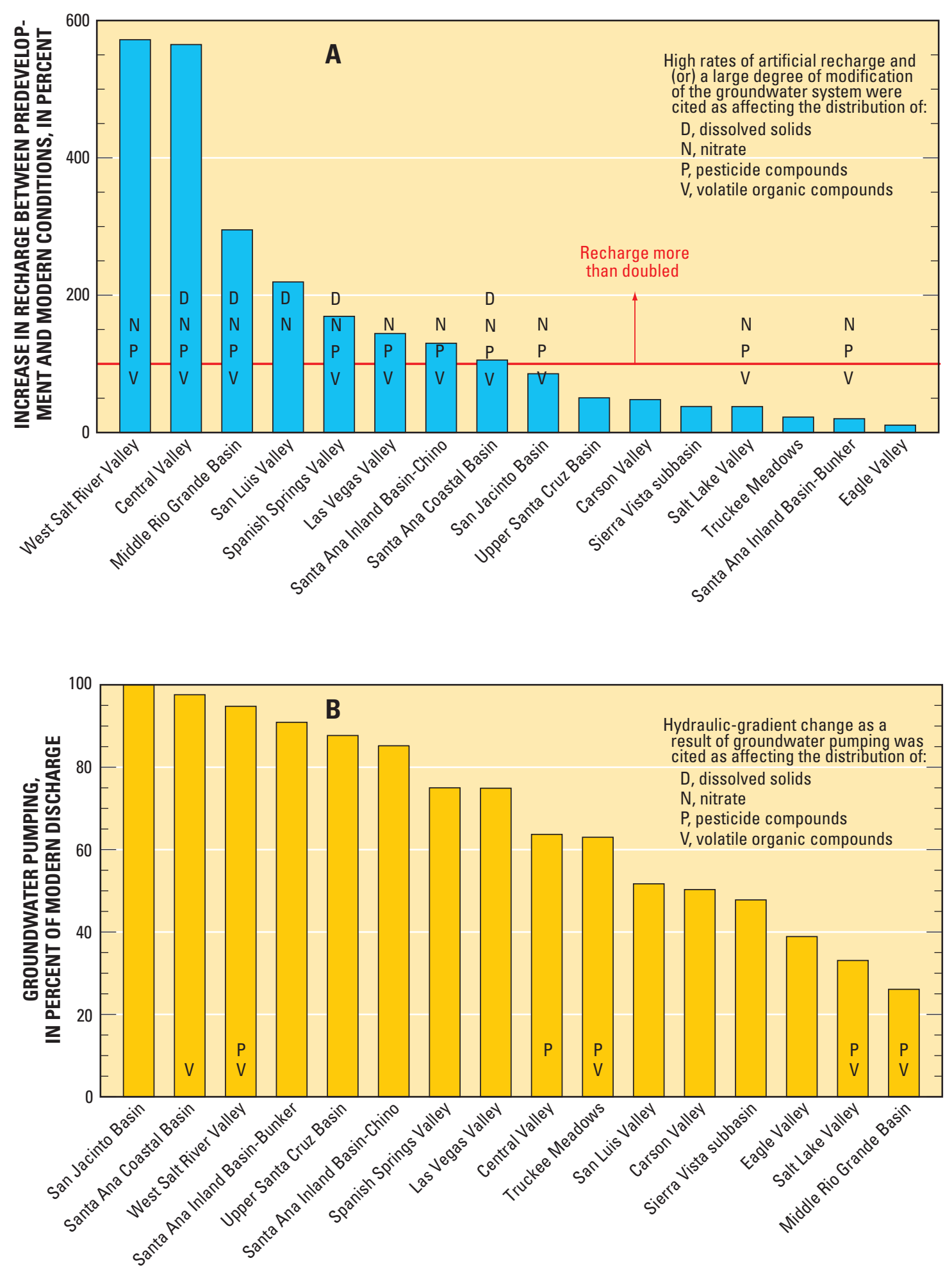

Figure 18. Comparison of the case-study basins in the Southwest Principal Aquifers study area where $A$, high rates of artificial recharge and (or) a large degree of modification of the groundwater system or $B$, hydraulic-gradient change as a result of groundwater pumping was cited as affecting the distribution of selected contaminants in groundwater. 
listed as a primary source in 10 of the 14 case-study basins where elevated nitrate concentrations have been documented (fig. 17).

Urban recharge sources (including municipal-supply water infiltrating through irrigated and fertilized yards/turf areas, urban runoff infiltrating as diffuse recharge, wastewater infiltrating from septic/sewer systems, treated urban wastewater infiltrating through irrigated fields, and (or) engineered recharge of various types) are listed as primary contributors to elevated nitrate concentrations in groundwater in 12 of the 14 basins where elevated nitrate concentrations have been documented (fig. 17). Of these 14 basins, only the 2 basins (San Luis Valley and Sierra Vista subbasin) with less than 5 percent urban land are not listed as having urban sources of elevated nitrate. The most commonly listed urban sources are wastewater leaking from sewer/septic systems (10 basins) and infiltration of urban irrigation water ( 8 basins). Treated urban wastewater infiltrating through irrigated fields/impoundments is listed as an important contributor in six basins, and urban runoff is listed in five basins.

The primary hydrogeologic controls on the locations and depths where nitrate concentrations exceed $5 \mathrm{mg} / \mathrm{L}$ in the basin-fill aquifers of the case-study basins include natural and human-related processes/characteristics. A natural control of major importance in allowing nitrate to form and (or) persist is the presence of oxic conditions in the aquifer, which is common in Southwestern alluvial basins and is listed as a factor in every case-study basin where elevated nitrate concentrations have been documented. High evapotranspiration of naturally discharging and naturally or artificially recharging water is cited as a factor in concentrating nitrate concentrations in four basins (Middle Rio Grande, San Luis Valley, Spanish Springs Valley, and West Salt River Valley). Another natural control important to the distribution of elevated nitrate concentrations in six basins (Eagle Valley, Las Vegas Valley, Salt Lake Valley, San Luis Valley, Santa Ana Coastal, and West Salt River Valley) is the presence of natural confining units and (or) upward hydraulic gradients that help to protect the deeper (used) aquifer from contamination that is present in the shallower aquifer.

Human-related controls of importance in contributing to the distribution of elevated nitrate concentrations in groundwater include the establishment of large sources of artificial recharge (resulting in increased modern recharge rates and younger overall groundwater ages) and the substantial modification of groundwater systems with respect to both recharge and discharge processes (resulting in increased groundwater flow rates and mixing). Case-study basins where large sources of artificial recharge and (or) high degrees of system modification are cited as contributing factors are the Central Valley, Las Vegas Valley, Middle Rio Grande, Salt Lake Valley, San Jacinto, San Luis Valley, Santa Ana Coastal, Santa Ana Inland, Spanish Springs Valley, and West Salt River Valley, which includes all eight basins where recharge has at least doubled between predevelopment and modern conditions (fig. 18). In each of the two basins where recharge has not at least doubled (Salt Lake Valley and San Jacinto), the quantity of artificial recharge per unit area is relatively high, at about 3 or more inches per year. In four basins (Middle Rio Grande, San Luis Valley, Santa Ana Inland, and West Salt River Valley), the presence of a shallow water table in areas where substantial quantities of artificial recharge are applied is listed as an important hydrogeologic control.

Overall, findings from the 15 case-study basins suggest that elevated nitrate concentrations in groundwater of Southwestern alluvial basins are not as areally or vertically extensive as elevated dissolved-solids concentrations and currently are not as limiting with respect to the use of untreated groundwater for drinking water. However, nitrate concentrations above $5 \mathrm{mg} / \mathrm{L}$ have been observed across broad areas and (or) depths in the aquifers of eight case-study basins, suggesting that nitrate is a constituent of concern, particularly for future use of the deeper groundwater resource. In four basins, sources associated with natural and human-related processes/ characteristics have been documented to contribute to the distribution of elevated nitrate concentrations. Potential natural sources are related to the evapotranspiration of infiltrating precipitation and (or) bacterial processes in the soil zone. Agricultural and urban recharge sources have been cited as important with nearly equal frequency and have been noted to contribute appreciably to elevated nitrate concentrations even in basins where the individual land use of interest accounts for only a small fraction of land use in the basin as a whole. Extensive modifications of the hydrologic system primarily for either agricultural or urban purposes have influenced the distribution of elevated nitrate concentrations in several basins. Natural hydrogeologic controls are occasionally cited as providing some measure of protection to the aquifer (particularly at greater depths) but are more commonly cited as contributing to elevated nitrate concentrations.

\section{Contaminants with Primarily Natural Sources}

\section{Arsenic}

Arsenic is a trace element that has been observed at elevated concentrations across broad areas of the southwestern United States (Welch and others, 2000). Although arsenic was once an ingredient in pesticides applied to specific crops, most arsenic in groundwater of the United States is associated with natural sources and (or) processes, including geothermal water, iron oxides (where arsenic tends to sorb), sulfide minerals, or evaporative concentration (Welch and others, 1999). As discussed in the "Aquifer Properties" section of this report, arsenic concentrations in groundwater also are dependent on redox conditions and $\mathrm{pH}$. The USEPA primary drinking-water standard for arsenic is $10 \mu \mathrm{g} / \mathrm{L}$ because of the potential for elevated arsenic concentrations to contribute to skin damage, circulatory problems, and certain types of cancer (U.S. Environmental Protection Agency, 2009). For this discussion, a concentration of $5 \mu \mathrm{g} / \mathrm{L}$ was selected as the threshold above which arsenic could be of concern because concentrations of this magnitude indicate the presence of arsenic sources that could result in exceedances of the drinking-water standard in some parts of the aquifer. 
Arsenic concentrations are known to exceed $5 \mu \mathrm{g} / \mathrm{L}$ in at least some part of the basin-fill aquifer in all 15 case-study basins and across broad areas of the basin-fill aquifer in 7 casestudy basins (Carson Valley, Eagle Valley, Middle Rio Grande, Salt Lake Valley, Spanish Springs Valley, Truckee Meadows, and West Salt River Valley) (table 10A). In seven basins, studies have documented that elevated arsenic concentrations commonly extend throughout various depths of the aquifer, and in one basin (Las Vegas Valley), elevated concentrations occur primarily in deep wells. In the other seven basins, the vertical extent of elevated arsenic concentrations has not been well defined.

In the 11 case-study basins where arsenic occurrence in groundwater has been sufficiently studied to make a determination about source, high-arsenic rocks/sediments in the recharge area and within the aquifer are commonly cited as primary sources. For the eight basins where natural recharge interacting with rocks or sediments prior to recharge is cited as a primary source (Carson Valley, Central Valley, Eagle Valley, Las Vegas Valley, Middle Rio Grande, Salt Lake Valley, Spanish Springs Valley, and Truckee Meadows), the median percentage of the surrounding hydrogeologic area covered by volcanic rocks is not significantly higher than for the other seven basins at the 95-percent probability level but is significantly higher at the 90-percent probability level (fig. 16). Only in the Middle Rio Grande Basin is high-arsenic water of deep and (or) geothermal origin listed as a primary source.

Other than the presence of high-arsenic rocks within the recharge area or aquifer, hydrogeologic controls on arsenic concentrations generally have not been well documented for more than a few of the 15 case-study basins. The presence of groundwater with long traveltimes, which would allow for greater rock-water interaction, is cited as an important arsenic control in the Central Valley, Middle Rio Grande, and Salt Lake Valley. The occurrence of high evapotranspiration rates of shallow discharging groundwater is cited as a control in two basins (Central Valley and Salt Lake Valley). In the Central Valley and Middle Rio Grande Basin, high $\mathrm{pH}$ values are cited as being conducive to desorption of arsenic from metal oxides in aquifer sediments. Additional controls each listed as being important for a single basin include the presence of anoxic conditions conducive to dissolution of metal oxides with adsorbed arsenic, artificial-recharge-induced changes to redox conditions in the aquifer, inflow of high-arsenic groundwater

Table 10. For each of the 15 case-study basins in the Southwest Principal Aquifers study area, locations where concentrations of $A$, arsenic, and $B$, uranium, which have primarily natural sources, exceed specified thresholds in groundwater and associated sources and hydrogeologic controls.

[Unless otherwise noted, references for information presented here are listed in corresponding basin chapters in Thiros and others (2010). Abbreviations: As, arsenic; $\mathrm{U}$, uranium; $\mu \mathrm{g} / \mathrm{L}$, micrograms per liter; ft, feet; ET, evapotranspiration; MRL, laboratory method reporting limit; GW, groundwater; <, less than; $>$, greater than]

\section{A. Arsenic, threshold concentration $5 \mu \mathrm{g} / \mathrm{L}$}

\begin{tabular}{|c|c|c|c|c|}
\hline \multirow[b]{2}{*}{ Basin } & \multicolumn{2}{|c|}{ Location(s) within groundwater flow system } & \multirow[b]{2}{*}{ Primary contaminant source(s) } & \multirow[b]{2}{*}{ Primary hydrogeologic control(s) } \\
\hline & $\begin{array}{l}\text { Areal location(s) where } \\
\text { As exceeds } 5 \mu \mathrm{g} / \mathrm{L}\end{array}$ & $\begin{array}{l}\text { Vertical location(s) } \\
\text { where As exceeds } \\
\qquad 5 \mu \mathrm{g} / \mathrm{L}\end{array}$ & & \\
\hline Carson Valley & $\begin{array}{l}18 \text { of } 37 \text { wells had } \\
\text { concentrations } \\
\text { greater than } 5 \mu \mathrm{g} / \mathrm{L}\end{array}$ & Most or all depths & $\begin{array}{l}\text { Natural recharge water that interacted with As- } \\
\text { containing rocks/sediments prior to recharge }\end{array}$ & $\begin{array}{l}\text { Presence of high-As bedrock/sediments in recharge } \\
\text { areas }\end{array}$ \\
\hline Central Valley & $\begin{array}{l}\text { Localized areas in } \\
\text { central and southern } \\
\text { parts of basin }\end{array}$ & Most or all depths & $\begin{array}{l}\text { Natural recharge water that interacted with As- } \\
\text { containing rocks/sediments prior to recharge; } \\
\text { As-containing rocks/sediments contacted by } \\
\text { GW along flow paths within the basin }\end{array}$ & $\begin{array}{l}\text { Presence of high-As bedrock/sediments in recharge } \\
\text { areas; presence of high-As aquifer sediments; } \\
\text { presence of anoxic GW conditions conducive } \\
\text { to dissolution of metal oxides with adsorbed } \\
\text { arsenic; presence of } \mathrm{GW} \text { pH values conducive } \\
\text { to desorption of arsenic from metal oxides in } \\
\text { sediments; presence of GW with very long } \\
\text { residence times; high ET of shallow GW in natural } \\
\text { discharge areas }\end{array}$ \\
\hline Eagle Valley & $\begin{array}{l}17 \text { of } 21 \text { wells had } \\
\text { concentrations } \\
\text { greater than } 5 \mu \mathrm{g} / \mathrm{L}, \\
\text { mostly in the central } \\
\text { parts of the basin }\end{array}$ & Most or all depths & $\begin{array}{l}\text { Natural recharge water that interacted with As- } \\
\text { containing rocks/sediments prior to recharge }\end{array}$ & $\begin{array}{l}\text { Presence of high-As bedrock/sediments in recharge } \\
\text { areas }\end{array}$ \\
\hline $\begin{array}{l}\text { Las Vegas } \\
\text { Valley }\end{array}$ & $\begin{array}{l}\text { Localized parts of } \\
\text { central, urban valley } \\
\text { floor areas }\end{array}$ & Primarily deep wells & $\begin{array}{l}\text { Natural recharge water that interacted with As- } \\
\text { containing rocks/sediments prior to recharge }\end{array}$ & $\begin{array}{l}\text { Presence of high-As bedrock/sediments in recharge } \\
\text { areas; presence of confining units inhibiting } \\
\text { upward vertical movement of high-As GW }\end{array}$ \\
\hline $\begin{array}{l}\text { Middle Rio } \\
\text { Grande }\end{array}$ & $\begin{array}{l}\text { Broad parts of the } \\
\text { western and north- } \\
\text { western areas of the } \\
\text { basin }\end{array}$ & Most or all depths & $\begin{array}{l}\text { Natural recharge water that interacted with As- } \\
\text { containing rocks/sediments prior to recharge; } \\
\text { As-containing rocks/sediments contacted by } \\
\text { GW along flow paths within the basin }\end{array}$ & $\begin{array}{l}\text { Presence of high-As bedrock/sediments (volcanics) } \\
\text { in recharge areas; presence of high-As aquifer } \\
\text { sediments; presence of GW pH values conducive } \\
\text { to desorption of arsenic from metal oxides in } \\
\text { aquifer sediments; recharge by high-As subsurface } \\
\text { inflow from adjacent basins; presence of GW with } \\
\text { very long residence times }\end{array}$ \\
\hline
\end{tabular}


Table 10. For each of the 15 case-study basins in the Southwest Principal Aquifers study area, locations where concentrations of $A$, arsenic, and $B$, uranium, which have primarily natural sources, exceed specified thresholds in groundwater and associated sources and hydrogeologic controls.-Continued

\section{A. Arsenic, threshold concentration $5 \mu \mathrm{g} / \mathrm{L}$}

\begin{tabular}{|c|c|c|c|c|}
\hline \multirow[b]{2}{*}{ Basin } & \multicolumn{2}{|c|}{ Location(s) within groundwater flow system } & \multirow[b]{2}{*}{ Primary contaminant source(s) } & \multirow[b]{2}{*}{ Primary hydrogeologic control(s) } \\
\hline & $\begin{array}{l}\text { Areal location(s) where } \\
\text { As exceeds } 5 \mu \mathrm{g} / \mathrm{L}\end{array}$ & $\begin{array}{l}\text { Vertical location(s) } \\
\text { where As exceeds } \\
\qquad 5 \mu \mathrm{g} / \mathrm{L}\end{array}$ & & \\
\hline $\begin{array}{l}\text { Middle Rio } \\
\text { Grande- } \\
\text { Continued }\end{array}$ & $\begin{array}{l}\text { Localized parts of the } \\
\text { eastern and central } \\
\text { areas of the basin }\end{array}$ & Most or all depths & $\begin{array}{l}\text { High-As water of deep and (or) geothermal } \\
\text { origin }\end{array}$ & $\begin{array}{l}\text { Presence of faults or other structural features } \\
\text { enhancing upward movement of high-As GW; } \\
\text { presence of GW with very long residence times }\end{array}$ \\
\hline $\begin{array}{l}\text { Salt Lake } \\
\text { Valley }\end{array}$ & $\begin{array}{l}\text { Much of the western } \\
\text { part of the valley }\end{array}$ & Most or all depths & $\begin{array}{l}\text { Natural recharge water that interacted with As- } \\
\text { containing rocks/sediments prior to recharge; } \\
\text { As-containing rocks/sediments contacted by } \\
\text { GW along flow paths within the basin }\end{array}$ & $\begin{array}{l}\text { Presence of high-As bedrock/sediments in recharge } \\
\text { areas; presence of high-As aquifer sediments; high } \\
\text { ET of shallow GW in natural discharge areas; } \\
\text { artificial-recharge-induced changes in GW redox } \\
\text { conditions conducive to As desorption and (or) } \\
\text { dissolution of As-containing aquifer materials; } \\
\text { presence of GW with very long residence times }\end{array}$ \\
\hline San Jacinto & $\begin{array}{l}\text { Localized areas in } \\
\text { central and southern } \\
\text { parts of basin; } 3 \text { of } 23 \\
\text { water-supply wells } \\
\text { exceeded } 5 \mu \mathrm{g} / \mathrm{L}\end{array}$ & Unknown/not assessed & Unknown/not assessed & Unknown/not assessed \\
\hline $\begin{array}{l}\text { San Luis } \\
\text { Valley }\end{array}$ & $\begin{array}{l}\text { Localized parts of the } \\
\text { San Luis closed basin } \\
\text { (particularly toward } \\
\text { the center) }\end{array}$ & $\begin{array}{l}\text { Not well defined, but } \\
\text { observed at depths } \\
\text { up to } 50 \mathrm{ft} \text { in the } \\
\text { unconfined aquifer }\end{array}$ & Unknown/not assessed & Unknown/not assessed \\
\hline $\begin{array}{l}\text { Santa Ana } \\
\text { Coastal }\end{array}$ & $\begin{array}{l}\text { Localized areas; } 1 \text { of } \\
20 \text { water-supply wells } \\
\text { and } 8 \text { of } 25 \text { shallow } \\
\text { monitoring wells } \\
\text { exceeded } 5 \mu \mathrm{g} / \mathrm{L}\end{array}$ & Unknown/not assessed & Unknown/not assessed & Unknown/not assessed \\
\hline $\begin{array}{l}\text { Santa Ana } \\
\text { Inland }\end{array}$ & $\begin{array}{l}\text { Localized areas; } 2 \text { of } \\
29 \text { water-supply wells } \\
\text { exceeded } 5 \mu \mathrm{g} / \mathrm{L}\end{array}$ & $\begin{array}{l}\text { Not well defined, but } \\
\text { perhaps mostly at } \\
\text { shallow depths }\end{array}$ & Unknown/not assessed & Unknown/not assessed \\
\hline $\begin{array}{l}\text { Sierra Vista } \\
\text { Subbasin }\end{array}$ & $\begin{array}{l}\text { Localized parts of the } \\
\text { basin. Five of } 39 \\
\text { ( } 13 \text { percent of) wells } \\
\text { distributed across } \\
\text { the basin exceeded } \\
10 \mu \mathrm{g} / \mathrm{L} \text {. More may } \\
\text { have exceeded } 5 \\
\mu \mathrm{g} / \mathrm{L}, \text { but the } 10 \mu \mathrm{g} / \mathrm{L} \\
\text { MRL precluded this } \\
\text { determination }\end{array}$ & Not assessed & $\begin{array}{l}\text { As-containing rocks/sediments contacted by GW } \\
\text { along flow paths within the basin }\end{array}$ & Presence of high-As aquifer sediments \\
\hline $\begin{array}{l}\text { Spanish } \\
\text { Springs Valley }\end{array}$ & Basin-wide & Most or all depths & $\begin{array}{l}\text { Natural recharge water that interacted with As- } \\
\text { containing rocks/sediments prior to recharge }\end{array}$ & $\begin{array}{l}\text { Presence of high-As bedrock/sediments in recharge } \\
\text { areas }\end{array}$ \\
\hline $\begin{array}{l}\text { Truckee } \\
\text { Meadows }\end{array}$ & $\begin{array}{l}\text { Central and northeast- } \\
\text { ern parts of basin }\end{array}$ & Most or all depths & $\begin{array}{l}\text { Natural recharge water that interacted with As- } \\
\text { containing rocks/sediments prior to recharge }\end{array}$ & $\begin{array}{l}\text { Presence of high-As bedrock/sediments in recharge } \\
\text { areas }\end{array}$ \\
\hline $\begin{array}{l}\text { Upper Santa } \\
\text { Cruz }\end{array}$ & $\begin{array}{l}\text { Localized parts of the } \\
\text { basin. Eight of } 58 \\
\text { ( } 14 \text { percent of) wells } \\
\text { distributed across } \\
\text { the basin exceeded } \\
10 \mu \mathrm{g} / \mathrm{L} . \text { More may } \\
\text { have exceeded } 5 \\
\mu \mathrm{g} / \mathrm{L}, \text { but the } 10 \mu \mathrm{g} / \mathrm{L} \\
\text { MRL precluded this } \\
\text { determination }\end{array}$ & Not assessed & $\begin{array}{l}\text { As-containing rocks/sediments contacted by GW } \\
\text { along flow paths within the basin }\end{array}$ & Presence of high-As aquifer sediments \\
\hline $\begin{array}{l}\text { West Salt } \\
\text { River Valley }\end{array}$ & $\begin{array}{l}\text { More than half of the } \\
35 \text { wells sampled } \\
\text { across the basin } \\
\text { had concentrations } \\
\text { greater than } 5 \mu \mathrm{g} / \mathrm{L}\end{array}$ & Not assessed & $\begin{array}{l}\text { As-containing rocks/sediments contacted by GW } \\
\text { along flow paths within the basin }\end{array}$ & Presence of high-As aquifer sediments \\
\hline
\end{tabular}


Table 10. For each of the 15 case-study basins in the Southwest Principal Aquifers study area, locations where concentrations of $A$, arsenic, and $B$, uranium, which have primarily natural sources, exceed specified thresholds in groundwater and associated sources and hydrogeologic controls.-Continued

\section{$B$. Uranium, threshold concentration $15 \mu \mathrm{g} / \mathrm{L}$}

\begin{tabular}{|c|c|c|c|c|}
\hline \multirow[b]{2}{*}{ Basin } & \multicolumn{2}{|c|}{ Location(s) within groundwater flow system } & \multirow[b]{2}{*}{ Primary contaminant source(s) } & \multirow[b]{2}{*}{ Primary hydrogeologic control(s) } \\
\hline & $\begin{array}{l}\text { Areal location(s) } \\
\text { where U exceeds } \\
\qquad 15 \mu \mathrm{g} / \mathrm{L}\end{array}$ & $\begin{array}{l}\text { Vertical location(s) } \\
\text { where U exceeds } \\
\qquad 15 \mu \mathrm{g} / \mathrm{L}\end{array}$ & & \\
\hline Carson Valley & $\begin{array}{l}4 \text { of } 30 \text { wells had } \\
\text { concentrations above } \\
15 \mu \mathrm{g} / \mathrm{L} \text {, mostly in } \\
\text { western part of the } \\
\text { basin }\end{array}$ & $\begin{array}{l}\text { Shallow part of the } \\
\text { aquifer, generally } \\
<20 \mathrm{ft} \text { from land } \\
\text { surface }\end{array}$ & $\begin{array}{l}\text { Natural recharge water that interacted with } \\
\text { U-containing rocks/sediments prior to } \\
\text { recharge; U-containing rocks/sediments } \\
\text { contacted by GW along flow paths within the } \\
\text { basin }\end{array}$ & $\begin{array}{l}\text { Presence of high-U bedrock/sediments in recharge } \\
\text { areas; presence of high-U aquifer sediments; } \\
\text { presence of oxic GW conditions conducive to } \\
\text { formation of mobile U complexes }\end{array}$ \\
\hline Central Valley & $\begin{array}{l}\text { Localized areas on } \\
\text { eastern side of basin }\end{array}$ & Not well defined & $\begin{array}{l}\text { Natural recharge water that interacted with } \\
\text { U-containing rocks/sediments prior to } \\
\text { recharge; U-containing rocks/sediments } \\
\text { contacted by GW along flow paths within the } \\
\text { basin }\end{array}$ & $\begin{array}{l}\text { Presence of high-U bedrock/sediments in recharge } \\
\text { areas and in aquifer sediments; presence of oxic } \\
\text { GW conditions conducive to formation of mobile } \\
U \text { complexes; pumping-induced and artificial- } \\
\text { recharge-induced changes in GW redox conditions } \\
\text { conducive to U mobilization }\end{array}$ \\
\hline Eagle Valley & $\begin{array}{l}5 \text { of } 30 \text { wells had } \\
\text { concentrations above } \\
15 \mu \mathrm{g} / \mathrm{L} \text {, mostly in } \\
\text { northern part of the } \\
\text { basin }\end{array}$ & $\begin{array}{l}\text { Mostly in deeper wells } \\
>100 \mathrm{ft} \text { from land } \\
\text { surface }\end{array}$ & $\begin{array}{l}\text { Natural recharge water that interacted with } \\
\text { U-containing rocks/sediments prior to } \\
\text { recharge; U-containing rocks/sediments } \\
\text { contacted by GW along flow paths within the } \\
\text { basin }\end{array}$ & $\begin{array}{l}\text { Presence of high-U bedrock/sediments in recharge } \\
\text { areas; presence of high-U aquifer sediments }\end{array}$ \\
\hline $\begin{array}{l}\text { Las Vegas } \\
\text { Valley }\end{array}$ & $\begin{array}{l}\text { South-central urban } \\
\text { area; } 4 \text { of } 5 \text { shallow } \\
\text { wells had concentra- } \\
\text { tions above } 15 \mu \mathrm{g} / \mathrm{L}\end{array}$ & $\begin{array}{l}\text { Shallow part of aqui- } \\
\text { fer within top } 50 \mathrm{ft}\end{array}$ & Not assessed & $\begin{array}{l}\text { Presence of confining units inhibiting downward } \\
\text { vertical movement of high-U GW }\end{array}$ \\
\hline \multirow[t]{2}{*}{$\begin{array}{l}\text { Middle Rio } \\
\text { Grande }\end{array}$} & $\begin{array}{l}\text { Localized areas along } \\
\text { the eastern mountain } \\
\text { front and in the valley } \\
\text { center }\end{array}$ & Most or all depths & $\begin{array}{l}\text { Natural recharge water that interacted with } \\
\text { U-containing rocks/sediments prior to } \\
\text { recharge; U-containing rocks/sediments } \\
\text { contacted by GW along flow paths within the } \\
\text { basin }\end{array}$ & $\begin{array}{l}\text { Presence of high-U bedrock/sediments in recharge } \\
\text { areas (granitic rocks); presence of high-U aquifer } \\
\text { sediments (of volcanic origin); presence of oxic } \\
\text { GW conditions conducive to formation of mobile } \\
\text { U complexes }\end{array}$ \\
\hline & $\begin{array}{l}\text { Localized areas along } \\
\text { the Rio Puerco and } \\
\text { possibly Abo Arroyo }\end{array}$ & Not well defined & $\begin{array}{l}\text { Natural recharge water that interacted with } \\
\text { U-containing rocks/sediments prior to recharge }\end{array}$ & $\begin{array}{l}\text { Presence of high-U bedrock/sediments in recharge } \\
\text { areas; presence of oxic } \mathrm{GW} \text { conditions conducive } \\
\text { to formation of mobile } \mathrm{U} \text { complexes }\end{array}$ \\
\hline $\begin{array}{l}\text { Salt Lake } \\
\text { Valley }\end{array}$ & $\begin{array}{l}\text { Localized areas in } \\
\text { southeastern part of } \\
\text { valley; } 1 \text { of } 47 \text { water- } \\
\text { supply wells and } 5 \\
\text { of } 30 \text { shallow wells } \\
\text { exceeded } 15 \mu \mathrm{g} / \mathrm{L}\end{array}$ & $\begin{array}{l}\text { Not well defined, but } \\
\text { perhaps mostly at } \\
\text { shallow depths }\end{array}$ & $\begin{array}{l}\text { Natural recharge water that interacted with } \\
\text { U-containing rocks/sediments prior to } \\
\text { recharge; U-containing rocks/sediments } \\
\text { contacted by GW along flow paths within the } \\
\text { basin }\end{array}$ & $\begin{array}{l}\text { Presence of high-U bedrock/sediments in recharge } \\
\text { areas; presence of high-U aquifer sediments; } \\
\text { presence of oxic GW conditions conducive to } \\
\text { formation of mobile U complexes }\end{array}$ \\
\hline San Jacinto & $\begin{array}{l}\text { Localized areas; } 1 \text { of } \\
23 \text { water-supply wells } \\
\text { exceeded } 15 \mu \mathrm{g} / \mathrm{L}\end{array}$ & $\begin{array}{l}\text { Unknown/not assessed } \\
\text { (no shallow samples } \\
\text { available) }\end{array}$ & Unknown/not assessed & Unknown/not assessed \\
\hline $\begin{array}{l}\text { San Luis } \\
\text { Valley }\end{array}$ & $\begin{array}{l}\text { Localized areas both } \\
\text { within and south of } \\
\text { the San Luis closed } \\
\text { basin (particularly } \\
\text { toward the valley } \\
\text { center) }\end{array}$ & $\begin{array}{l}\text { Not well defined, but } \\
\text { at least to depths } \\
\text { generally }<120 \mathrm{ft} \\
\text { and above the } \\
\text { confining unit }\end{array}$ & Unknown/not assessed & Unknown/not assessed \\
\hline $\begin{array}{l}\text { Santa Ana } \\
\text { Coastal }\end{array}$ & $\begin{array}{l}\text { Localized areas; } 2 \text { of } \\
20 \text { water-supply wells } \\
\text { and } 14 \text { of } 25 \text { shallow } \\
\text { wells exceeded } 15 \\
\mu \mathrm{g} / \mathrm{L}\end{array}$ & $\begin{array}{l}\text { Not well defined, but } \\
\text { perhaps mostly at } \\
\text { shallow depths }\end{array}$ & Unknown/not assessed & Unknown/not assessed \\
\hline $\begin{array}{l}\text { Santa Ana } \\
\text { Inland }\end{array}$ & $\begin{array}{l}\text { Localized areas; } 3 \text { of } \\
29 \text { water-supply wells } \\
\text { exceeded } 15 \mu \mathrm{g} / \mathrm{L}\end{array}$ & $\begin{array}{l}\text { Unknown/not assessed } \\
\text { (no shallow samples } \\
\text { available) }\end{array}$ & Unknown/not assessed & Unknown/not assessed \\
\hline $\begin{array}{l}\text { Sierra Vista } \\
\text { subbasin }\end{array}$ & $\begin{array}{l}\text { Localized parts of } \\
\text { basin. Only } 1 \text { of } 26 \\
\text { ( } 4 \text { percent of) wells } \\
\text { distributed across } \\
\text { the basin contained } \\
\text { concentrations above } \\
15 \mu \mathrm{g} / \mathrm{L}\end{array}$ & Not well defined & Unknown/not assessed & Unknown/not assessed \\
\hline
\end{tabular}


Table 10. For each of the 15 case-study basins in the Southwest Principal Aquifers study area, locations where concentrations of $A$, arsenic, and $B$, uranium, which have primarily natural sources, exceed specified thresholds in groundwater and associated sources and hydrogeologic controls. - Continued

\section{$B$. Uranium, threshold concentration $15 \mu \mathrm{g} / \mathrm{L}$}

\begin{tabular}{|c|c|c|c|c|}
\hline \multirow[b]{2}{*}{ Basin } & \multicolumn{2}{|c|}{ Location(s) within groundwater flow system } & \multirow[b]{2}{*}{ Primary contaminant source(s) } & \multirow[b]{2}{*}{ Primary hydrogeologic control(s) } \\
\hline & $\begin{array}{l}\text { Areal location(s) } \\
\text { where U exceeds } \\
\qquad 15 \mu \mathrm{g} / \mathrm{L}\end{array}$ & $\begin{array}{l}\text { Vertical location(s) } \\
\text { where U exceeds } \\
\qquad 15 \mu \mathrm{g} / \mathrm{L}\end{array}$ & & \\
\hline $\begin{array}{l}\text { Spanish } \\
\text { Springs Valley }\end{array}$ & $\begin{array}{l}3 \text { of } 9 \text { shallow wells } \\
\text { were above } 15 \mu \mathrm{g} / \mathrm{L} \\
\text { in central-eastern part } \\
\text { of basin }\end{array}$ & $\begin{array}{l}\text { Mostly }<75 \mathrm{ft} \text { from } \\
\text { land surface }\end{array}$ & $\begin{array}{l}\text { Natural recharge water that interacted with } \\
\text { U-containing rocks/sediments prior to recharge }\end{array}$ & $\begin{array}{l}\text { Presence of high- } U \text { bedrock/sediments in recharge } \\
\text { areas }\end{array}$ \\
\hline $\begin{array}{l}\text { Truckee } \\
\text { Meadows }\end{array}$ & $\begin{array}{l}\text { Along Truckee } \\
\text { River corridor and } \\
\text { in southeastern area; } \\
7 \text { of } 28 \text { samples were } \\
\text { above } 15 \mu \mathrm{g} / \mathrm{L}\end{array}$ & $\begin{array}{l}\text { Shallow part of aqui- } \\
\text { fer within } 50 \mathrm{ft} \text { of } \\
\text { land surface }\end{array}$ & $\begin{array}{l}\text { Natural recharge water that interacted with } \\
\text { U-containing rocks/sediments prior to recharge }\end{array}$ & $\begin{array}{l}\text { Presence of high-U bedrock/sediments in recharge } \\
\text { areas; presence of high- } U \text { aquifer sediments (of } \\
\text { volcanic origin); presence of oxic GW conditions } \\
\text { conducive to formation of mobile } U \text { complexes }\end{array}$ \\
\hline $\begin{array}{l}\text { Upper Santa } \\
\text { Cruz }\end{array}$ & $\begin{array}{l}\text { Localized parts of } \\
\text { basin. Four of } 29 \\
\text { (14 percent of) wells } \\
\text { distributed across } \\
\text { the basin contained } \\
\text { concentrations above } \\
15 \mu \mathrm{g} / \mathrm{L}\end{array}$ & Not well defined & Unknown/not assessed & Unknown/not assessed \\
\hline \multirow[t]{2}{*}{$\begin{array}{l}\text { West Salt } \\
\text { River Valley }\end{array}$} & $\begin{array}{l}\text { Western part of basin, } \\
\text { near Buckeye. Nine } \\
\text { of } 9(100 \text { percent } \\
\text { of }) \text { wells in an } \\
\text { agricultural area had } \\
\text { concentrations above } \\
15 \mu \mathrm{g} / \mathrm{L}\end{array}$ & $\begin{array}{l}\text { Shallow part of } \\
\text { aquifer above clay } \\
\text { layer, generally the } \\
\text { top } 10 \mathrm{ft}\end{array}$ & $\begin{array}{l}\text { Likely sources include natural recharge water } \\
\text { that interacted with U-containing rocks/ } \\
\text { sediments prior to recharge; U-containing } \\
\text { rocks/sediments contacted by GW along flow } \\
\text { paths within the basin }\end{array}$ & $\begin{array}{l}\text { Likely controls include presence of high-U bedrock/ } \\
\text { sediments in recharge areas (granitic rocks); } \\
\text { presence of high-U aquifer sediments; presence } \\
\text { of oxic GW conditions conducive to formation of } \\
\text { mobile U complexes }\end{array}$ \\
\hline & $\begin{array}{l}\text { Localized; } 14 \text { of } 64 \\
\text { ( } 22 \text { percent of) wells } \\
\text { distributed across } \\
\text { the basin contained } \\
\text { concentrations above } \\
15 \mu \mathrm{g} / \mathrm{L}\end{array}$ & All parts & $\begin{array}{l}\text { Likely sources include natural recharge water } \\
\text { that interacted with U-containing rocks/ } \\
\text { sediments prior to recharge; U-containing } \\
\text { rocks/sediments contacted by GW along flow } \\
\text { paths within the basin }\end{array}$ & $\begin{array}{l}\text { Likely controls include presence of high-U bedrock/ } \\
\text { sediments in recharge areas (granitic rocks); } \\
\text { presence of high-U aquifer sediments; presence } \\
\text { of oxic GW conditions conducive to formation of } \\
\text { mobile U complexes }\end{array}$ \\
\hline
\end{tabular}

from adjacent basins, upwelling of high-arsenic water along faults, and presence of naturally downward hydraulic gradients inhibiting upward movement of high-arsenic groundwater.

Overall, findings from the 15 Southwestern case-study basins indicate that elevated arsenic concentrations (exceeding $5 \mu \mathrm{g} / \mathrm{L}$ ) have been observed in groundwater across broad areas and (or) depths in the aquifers of 9 case-study basins, suggesting that arsenic is a constituent of concern for use of the groundwater resource. Although release of arsenic through either dissolution or desorption from rocks and sediments in the recharge area and (or) aquifer is known to be the primary source of elevated arsenic concentrations in Southwestern alluvial basins, few studies appear to have established the specific aquifer conditions and hydrogeologic controls that result in the release of arsenic to groundwater in the 15 case-study basins.

\section{Uranium}

Uranium is a radioactive trace element that has been observed at elevated concentrations in several Southwestern basin-fill aquifers (DeSimone, 2009). Most uranium in groundwater is associated with its natural release from rocks having relatively high uranium content, including granites.
Oxic conditions favor uranium mobility. The USEPA primary drinking-water standard for uranium is $30 \mu \mathrm{g} / \mathrm{L}$ because of the potential for elevated uranium concentrations to contribute to kidney damage and certain types of cancer (U.S. Environmental Protection Agency, 2009). For this discussion, a concentration of $15 \mu \mathrm{g} / \mathrm{L}$ was selected as the threshold above which uranium could be of concern because concentrations of this magnitude indicate the presence of uranium sources that could result in exceedances of the drinking-water standard in some parts of the aquifer.

Uranium concentrations are known to exceed $15 \mu \mathrm{g} / \mathrm{L}$ in at least some part of the basin-fill aquifer in all 15 case-study basins but across broad areas of the basin-fill aquifer only in the West Salt River Valley, where elevated uranium concentrations have been detected at various depths in the aquifer (table 10B). Among the five other basins where the distribution of elevated uranium concentrations with depth has been characterized, four (Carson Valley, Las Vegas Valley, Spanish Springs Valley, and Truckee Meadows) have elevated uranium primarily at shallow depths, one (Eagle Valley) has elevated uranium primarily at greater depths, and one (Middle Rio Grande) has elevated uranium throughout various depths, although in only localized geographic areas. 
In the eight case-study basins where uranium occurrence in groundwater has been sufficiently studied to make a determination about source, high-uranium rocks/sediments in the recharge area and within the aquifer are commonly cited as primary sources. The median percentage of the surrounding hydrogeologic area covered by metamorphic or intrusive igneous rocks is not significantly higher at either the 90 - or 95-percent probability level for the eight basins where natural recharge with high-uranium rocks prior to recharge is cited as a primary source relative to the other seven basins (fig. 16); however, the median percentage of the surrounding hydrogeologic area covered by volcanic rocks is significantly higher for the first group at the 90-percent probability level. Water of deep and (or) geothermal origin is not listed as a primary source of elevated uranium in any of the 15 case-study basins.

Other than the presence of high-uranium rocks within the recharge area or aquifer, hydrogeologic controls on uranium concentrations generally have not been well documented for more than a few of the 15 case-study basins. However, the presence of oxic conditions conducive to formation of mobile uranium complexes is cited as a control in six basins (Carson Valley, Central Valley, Middle Rio Grande, Salt Lake Valley, Truckee Meadows, and West Salt River Valley). Pumpinginduced and artificial-recharge-induced alteration of redox conditions is listed as a control in the Central Valley, and the presence of confining units inhibiting downward movement of high-uranium groundwater is listed as a control in the Las Vegas Valley.

Overall, findings from the 15 Southwestern case-study basins indicate that elevated uranium concentrations (exceeding $15 \mu \mathrm{g} / \mathrm{L}$ ) have been observed in groundwater across broad areas and (or) depths in the aquifers of only 2 case-study basins, suggesting that uranium is primarily only a localized constituent of concern for use of the groundwater resource. Although release of uranium from rocks and sediments in the recharge area and (or) aquifer is known to be the primary source of elevated uranium concentrations in Southwestern alluvial basins, few studies appear to have established the specific aquifer conditions and hydrogeologic controls that result in the release of uranium to groundwater in the 15 case-study basins.

\section{Contaminants with Primarily Human Sources}

\section{Volatile Organic Compounds}

Organic compounds that move relatively easily between water and air can be grouped into a general contaminant class known as volatile organic compounds (VOCs), which are primarily of human origin. Compounds that are categorized as VOCs include gasoline hydrocarbons and oxygenates, solvents, trihalomethanes (THMs, by-products of water chlorination), refrigerants, and fumigants. Zogorski and others (2006) discuss the specific VOCs that have been included in assessments conducted by NAWQA, including general sources and uses of these compounds. As described in the "Urban Sources" section of this report, VOCs can be associated with either point or diffuse sources that are most commonly present in urban areas. Some VOCs are more persistent and mobile under oxic conditions, whereas others are more persistent under anoxic conditions. The USEPA has established primary drinkingwater standards for 29 VOCs because of the potential for these compounds to increase the risk of certain types of cancer and (or) to contribute to nervous, circulatory, reproductive, and respiratory problems (Zogorski and others, 2006); for many of these compounds, the drinking-water standard has been set at $5 \mu \mathrm{g} / \mathrm{L}$ or less (U.S. Environmental Protection Agency, 2009). For this discussion, all detections of VOCs in groundwater are considered to be a potential cause for concern because detection at any concentration is indicative of vulnerability of that aquifer to human-related contamination. Information on observed VOC concentrations is listed on table 11A, including an indicator of whether compounds might have been detected at concentrations known to be of concern for human health.

VOCs have been detected in at least part of the basin-fill aquifer in 14 of 15 case-study basins and across broad areas of the basin-fill aquifer in 10 basins (Central Valley, Las Vegas Valley, Salt Lake Valley, San Jacinto, Santa Ana Coastal, Santa Ana Inland, Sierra Vista subbasin, Truckee Meadows, Upper Santa Cruz, and West Salt River Valley), including basins with relatively small but dispersed urban areas (table $11 \mathrm{~A}$ and fig. 17). Among the 14 basins where the distribution of VOC detections with depth has been characterized, 12 have had detections throughout various depths, generally including depths where wells are completed for public supply. Eagle Valley and San Luis Valley are the only basins where studies do not indicate several detections of VOCs beyond the shallow aquifer.

Findings with respect to the types of VOCs detected in groundwater of the 15 SWPA case-study basins were similar to findings of the nationwide NAWQA assessment by Zogorski and others (2006). The VOCs most commonly detected in the case-study basins were THMs and solvents (detected in 13 and 11 basins, respectively). VOCs of all other types except fumigants were each detected in four to six basins (fumigants were detected in two). Where detected, individual VOCs, regardless of type, were generally present at concentrations below $5 \mu \mathrm{g} / \mathrm{L}$, although higher concentrations were measured in some instances.

In only one case-study basin (the Central Valley) has irrigation associated with agricultural land use been documented to be a major source of a VOC to the aquifer (fig. 17). In the Central Valley, the soil fumigant dibromochloropropane (DBCP) was used in orchards and vineyards from the 1950s until its use was banned in 1977. In the eastern San Joaquin Valley, DBCP has been detected in groundwater at concentrations above the primary drinking-water standard to depths of nearly $130 \mathrm{ft}$ below the water table (Burow and others, 2007).

With the exception of DBCP, the VOCs detected in groundwater of the case-study basins are associated with urban uses. The two urban recharge sources most commonly listed as important sources of VOCs to groundwater of the basins are urban point sources (which can include landfills, leaky storage tanks, spills, and (or) improper disposal points in industrial, 
commercial, and (or) military settings) and chlorinated municipal-supply water infiltrating through irrigated yards/turf areas or leaking from distribution pipes. Chlorinated municipal-supply water is the most likely source of THMs, whereas urban point sources are more likely to contribute solvents, gasoline compounds, and organic synthesis compounds to groundwater. Other urban sources that can contribute various types of VOCs include urban runoff (listed as important for six basins), wastewater leaking from sewer or septic systems (listed for two basins), treated urban wastewater infiltrating through streams or fields (listed for two basins), and engineered recharge (listed for two basins).

The primary hydrogeologic controls on the locations and depths where VOCs have been detected in the basin-fill aquifers of 14 case-study basins include natural and human-related processes/characteristics. As mentioned previously, a natural control of major importance in allowing VOCs to persist is the redox conditions in the aquifer, which are listed as a factor in 13 basins. The oxic conditions that are typically found in Southwestern basin-fill aquifers are more conducive to the persistence of many THMs and solvents than of many petroleum hydrocarbons. Another natural control important to the distribution of VOCs in nine basins is the direction of natural vertical hydraulic gradients. In five basins (Central Valley, Salt Lake Valley, San Jacinto, Santa Ana Coastal, and Santa Ana Inland), natural downward gradients are listed as important in enhancing downward movement of VOCs that reach the water table in at least some areas; in five basins (Eagle Valley, Las Vegas Valley, Salt Lake Valley, San Luis Valley, and West Salt River Valley), natural upward gradients and (or) the existence of confining units are listed as important controls that in at least some areas help to protect the deeper (used) aquifer from contamination that is present in the shallower aquifer.

Human-related controls of importance in contributing to the distribution of VOCs in groundwater include the establishment of large sources of artificial recharge (resulting in increased modern recharge rates and younger overall groundwater ages), the initiation of large quantities of groundwater pumping (resulting in alteration of flow directions and gradients), and (or) the substantial modification of groundwater systems with respect to recharge and discharge processes (resulting in increased groundwater flow rates and mixing).

Table 11. For each of the 15 case-study basins in the Southwest Principal Aquifers study area, locations where $A$, volatile organic compounds, and $B$, pesticide compounds, which have primarily human sources, have been detected in groundwater and associated sources and hydrogeologic controls.

[Unless otherwise noted, references for information presented here are listed in corresponding basin chapters in Thiros and others (2010). Abbreviations: VOC, volatile organic compound; $\mu \mathrm{g} / \mathrm{L}$, micrograms per liter; ft, feet; THM, trihalomethane; GW, groundwater; <, less than; >, greater than; NAWQA, National WaterQuality Assessment Program; PCE, tetrachloroethylene; MTBE, methyl tert-butyl ether; DCE, dichloroethylene; CFC, chlorofluorocarbon; BTEX, the gasoline hydrocarbons benzene, toluene, ethylbenzene, and xylenes; p,p'-DDE, a degradate of the organochlorine pesticide p,p'-DDT]

\section{A. Volatile organic compounds}

\begin{tabular}{|c|c|c|c|c|c|c|}
\hline \multirow[b]{2}{*}{ Basin } & \multicolumn{2}{|c|}{$\begin{array}{c}\text { Location(s) within groundwater flow } \\
\text { system }\end{array}$} & \multirow{2}{*}{$\begin{array}{l}\text { Types of VOCs } \\
\text { observed }\end{array}$} & \multirow{2}{*}{$\begin{array}{c}\text { Observed } \\
\text { concentrations of } \\
\text { VOCs }\end{array}$} & \multirow[b]{2}{*}{ Human source(s) } & \multirow[b]{2}{*}{ Primary hydrogeologic control(s) } \\
\hline & $\begin{array}{c}\text { Areal location(s) } \\
\text { where VOCs have } \\
\text { been detected }\end{array}$ & $\begin{array}{c}\text { Vertical location(s) } \\
\text { where VOCs ave } \\
\text { been detected }\end{array}$ & & & & \\
\hline Carson Valley & No data & Not assessed & No data & No data & Unknown/not assessed & Unknown/not assessed \\
\hline Central Valley & $\begin{array}{l}\text { Much of basin, } \\
\text { more frequently } \\
\text { on the eastern side } \\
\text { of the San Joaquin } \\
\text { Valley where most } \\
\text { recharge occurs }\end{array}$ & $\begin{array}{l}\text { Most depths, } \\
\text { although more } \\
\text { frequently detected } \\
\text { in shallower } \\
\text { rather than deeper } \\
\text { production wells } \\
\text { in unconfined part } \\
\text { of basin }\end{array}$ & $\begin{array}{l}\text { Chloroform and } \\
\text { the soil fumigant } \\
\text { dibromochloro- } \\
\text { propane (DBCP) }\end{array}$ & Generally $<1 \mu \mathrm{g} / \mathrm{L}$ & $\begin{array}{l}\text { Chlorinated municipal-supply } \\
\text { water infiltrating through } \\
\text { irrigated yards/turf areas or } \\
\text { leaking from distribution pipes; } \\
\text { agricultural irrigation water } \\
\text { infiltrating through canals and } \\
\text { (or) fields where VOCs have } \\
\text { been applied as a pesticide }\end{array}$ & $\begin{array}{l}\text { Presence of GW redox } \\
\text { conditions conducive to } \\
\text { compound persistence; } \\
\text { presence of natural hydraulic } \\
\text { gradients enhancing downward } \\
\text { GW movement; large sources } \\
\text { of potential artificial recharge } \\
\text { and associated high modern } \\
\text { recharge rates and young GW } \\
\text { ages }\end{array}$ \\
\hline Eagle Valley & $\begin{array}{l}5 \text { of } 7 \text { wells used } \\
\text { for municipal } \\
\text { supply had VOC } \\
\text { detections in } \\
\text { northern part of } \\
\text { basin }\end{array}$ & $\begin{array}{l}\text { Less than } 250 \mathrm{ft} \\
\text { from land surface }\end{array}$ & $\begin{array}{l}\text { Solvents, organic } \\
\text { synthesis } \\
\text { compounds, } \\
\text { gasoline related } \\
\text { hydrocarbons, } \\
\text { THMs }\end{array}$ & Generally $<2 \mu \mathrm{g} / \mathrm{L}$ & $\begin{array}{l}\text { Urban point sources that might } \\
\text { include landfills, leaky storage } \\
\text { tanks, spills, and (or) improper } \\
\text { disposal points in industrial, } \\
\text { commercial, and (or) military } \\
\text { settings }\end{array}$ & $\begin{array}{l}\text { Presence of natural hydraulic } \\
\text { gradients inhibiting downward } \\
\text { GW movement; presence } \\
\text { of GW redox conditions } \\
\text { conducive to compound } \\
\text { persistence }\end{array}$ \\
\hline $\begin{array}{l}\text { Las Vegas } \\
\text { Valley }\end{array}$ & $\begin{array}{l}\text { Urban areas across } \\
\text { much of the basin }\end{array}$ & All depths & THMs, solvents & $\begin{array}{l}\text { Generally }>5 \mu \mathrm{g} / \mathrm{L} \\
\text { and as high as } \\
89 \mu \mathrm{g} / \mathrm{L}\end{array}$ & $\begin{array}{l}\text { Engineered recharge of urban } \\
\text { runoff or treated wastewater } \\
\text { through injection wells; } \\
\text { chlorinated municipal-supply } \\
\text { water infiltrating through } \\
\text { turf areas and leaking from } \\
\text { distribution pipes }\end{array}$ & $\begin{array}{l}\text { Presence of confining units } \\
\text { inhibiting downward GW } \\
\text { movement; presence of a } \\
\text { shallow water table in areas } \\
\text { with large sources of potential } \\
\text { artificial recharge; high degree } \\
\text { of modification of the GW sys- } \\
\text { tem (recharge and discharge), } \\
\text { resulting in increased flow rates } \\
\text { and mixing; presence of GW } \\
\text { redox conditions conducive to } \\
\text { compound persistence }\end{array}$ \\
\hline
\end{tabular}


Table 11. For each of the 15 case-study basins in the Southwest Principal Aquifers study area, locations where $A$, volatile organic compounds, and $B$, pesticide compounds, which have primarily human sources, have been detected in groundwater and associated sources and hydrogeologic controls.-Continued

\section{A. Volatile organic compounds}

\begin{tabular}{|c|c|c|c|c|c|c|}
\hline \multirow[b]{2}{*}{ Basin } & \multicolumn{2}{|c|}{$\begin{array}{l}\text { Location(s) within groundwater flow } \\
\text { system }\end{array}$} & \multirow{2}{*}{$\begin{array}{l}\text { Types of VOCs } \\
\text { observed }\end{array}$} & \multirow{2}{*}{$\begin{array}{c}\text { Observed } \\
\text { concentrations of } \\
\text { VOCs }\end{array}$} & \multirow[b]{2}{*}{ Human source(s) } & \multirow[b]{2}{*}{ Primary hydrogeologic control(s) } \\
\hline & $\begin{array}{c}\text { Areal location(s) } \\
\text { where VOCs have } \\
\text { been detected }\end{array}$ & $\begin{array}{c}\text { Vertical location(s) } \\
\text { where VOCs ave } \\
\text { been detected }\end{array}$ & & & & \\
\hline \multirow[t]{2}{*}{$\begin{array}{l}\text { Middle Rio } \\
\text { Grande }\end{array}$} & $\begin{array}{l}\text { Localized areas of } \\
\text { the Rio Grande } \\
\text { inner valley, } \\
\text { particularly in and } \\
\text { near Albuquerque }\end{array}$ & $\begin{array}{l}\text { Primarily shallow } \\
\text { GW (depths }<100 \\
\mathrm{ft} \text { ); occasional } \\
\text { detections up to } \\
\text { a couple hundred } \\
\text { feet below the } \\
\text { water table }\end{array}$ & $\begin{array}{l}\text { Solvents; gasoline } \\
\text { hydrocarbons; } \\
\text { gasoline } \\
\text { oxygenates; } \\
\text { THMs }\end{array}$ & $\begin{array}{l}\text { Generally }<2 \mu \mathrm{g} / \mathrm{L} \text {, } \\
\text { except near } \\
\text { known chemical } \\
\text { releases }\end{array}$ & $\begin{array}{l}\text { Urban point sources that include } \\
\text { landfills, leaky storage tanks, } \\
\text { spills, and (or) improper } \\
\text { disposal points in industrial, } \\
\text { commercial, and (or) military } \\
\text { settings; possible contributions } \\
\text { of some compounds from } \\
\text { chlorinated municipal-supply } \\
\text { water infiltrating through } \\
\text { irrigated yards/turf areas or } \\
\text { leaking from distribution pipes; } \\
\text { possible contributions of some } \\
\text { compounds from wastewater } \\
\text { leaking from urban sewer } \\
\text { pipes or infiltrating from septic } \\
\text { systems }\end{array}$ & $\begin{array}{l}\text { Presence of a shallow water } \\
\text { table in areas with large } \\
\text { sources of potential artificial } \\
\text { recharge; pumping-enhanced } \\
\text { downward and (or) horizontal } \\
\text { movement of GW containing } \\
\text { VOCs; presence of GW } \\
\text { redox conditions conducive } \\
\text { to compound persistence; } \\
\text { high degree of modification } \\
\text { of the GW system (recharge } \\
\text { and discharge), resulting in } \\
\text { increased flow rates and mixing }\end{array}$ \\
\hline & $\begin{array}{l}\text { Very localized } \\
\text { areas outside the } \\
\text { Rio Grande inner } \\
\text { valley, particularly } \\
\text { in and near } \\
\text { Albuquerque }\end{array}$ & $\begin{array}{l}\text { Depths up to at least } \\
\text { a couple hundred } \\
\text { feet below the } \\
\text { water table }\end{array}$ & $\begin{array}{l}\text { Solvents; gasoline } \\
\text { hydrocarbons; } \\
\text { gasoline } \\
\text { oxygenates; } \\
\text { THMs }\end{array}$ & Generally $<2 \mu \mathrm{g} / \mathrm{L}$ & $\begin{array}{l}\text { Urban point sources that include } \\
\text { landfills, leaky storage tanks, } \\
\text { spills, and (or) improper } \\
\text { disposal points in industrial, } \\
\text { commercial, and (or) military } \\
\text { settings; possible contributions } \\
\text { of some compounds from } \\
\text { chlorinated municipal-supply } \\
\text { water infiltrating through } \\
\text { irrigated yards/turf areas or } \\
\text { leaking from distribution pipes; } \\
\text { possible contributions of some } \\
\text { compounds from wastewater } \\
\text { leaking from urban sewer } \\
\text { pipes or infiltrating from septic } \\
\text { systems }\end{array}$ & $\begin{array}{l}\text { Pumping-enhanced downward } \\
\text { and (or) horizontal movement } \\
\text { of GW containing VOCs; } \\
\text { presence of GW redox } \\
\text { conditions conducive to } \\
\text { compound persistence; possible } \\
\text { presence of preferential flow } \\
\text { paths (such as wellbores) } \\
\text { between different aquifer } \\
\text { depths }\end{array}$ \\
\hline \multirow[t]{2}{*}{$\begin{array}{l}\text { Salt Lake } \\
\text { Valley }\end{array}$} & $\begin{array}{l}\text { Broad areas of the } \\
\text { valley with recent } \\
\text { residential land use }\end{array}$ & $\begin{array}{l}\text { Detected in } 28 \text { of } 30 \\
\text { shallow monitoring } \\
\text { wells sampled by } \\
\text { NAWQA in valley }\end{array}$ & THMs, solvents & $\begin{array}{l}\text { Generally less } \\
\text { than } 0.1 \mu \mathrm{g} / \mathrm{L} \text {, } \\
\text { except for some } \\
\text { samples with } \\
\text { THMs }>1 \mu \mathrm{g} / \mathrm{L}\end{array}$ & $\begin{array}{l}\text { Chlorinated municipal-supply } \\
\text { water infiltrating through } \\
\text { irrigated yards/turf areas or } \\
\text { leaking from distribution pipes; } \\
\text { wastewater leaking from urban } \\
\text { sewer pipes or infiltrating from } \\
\text { septic systems; urban point } \\
\text { sources that might include } \\
\text { landfills, leaky storage tanks, } \\
\text { spills, and (or) improper } \\
\text { disposal points in industrial, } \\
\text { commercial, and (or) military } \\
\text { settings; urban runoff infiltrating } \\
\text { through streams and (or) as } \\
\text { diffuse recharge }\end{array}$ & $\begin{array}{l}\text { Presence of GW redox } \\
\text { conditions conducive to } \\
\text { compound persistence; } \\
\text { presence of confining units } \\
\text { inhibiting downward GW } \\
\text { movement; large sources of } \\
\text { potential artificial recharge } \\
\text { and associated high modern } \\
\text { recharge rates and young GW } \\
\text { ages }\end{array}$ \\
\hline & $\begin{array}{l}\text { Broad areas of } \\
\text { valley, particularly } \\
\text { in areas with a } \\
\text { component of } \\
\text { recent recharge } \\
\text { and a downward } \\
\text { hydraulic gradient }\end{array}$ & $\begin{array}{l}\text { Depths typically } \\
\text { accessed by public- } \\
\text { supply wells }\end{array}$ & $\begin{array}{l}\text { THMs, solvents, } \\
\text { refrigerants }\end{array}$ & $\begin{array}{l}\text { Generally less } \\
\text { than } 0.1 \mu \mathrm{g} / \mathrm{L} \text {, } \\
\text { except for some } \\
\text { samples with } \\
\text { THMs }>1 \mu \mathrm{g} / \mathrm{L}\end{array}$ & $\begin{array}{l}\text { Chlorinated municipal-supply } \\
\text { water infiltrating through } \\
\text { irrigated yards/turf areas or } \\
\text { leaking from distribution pipes; } \\
\text { wastewater leaking from urban } \\
\text { sewer pipes or infiltrating from } \\
\text { septic systems; urban point } \\
\text { sources that might include } \\
\text { landfills, leaky storage tanks, } \\
\text { spills, and (or) improper } \\
\text { disposal points in industrial, } \\
\text { commercial, and (or) military } \\
\text { settings; urban runoff infiltrating } \\
\text { through streams and (or) as } \\
\text { diffuse recharge }\end{array}$ & $\begin{array}{l}\text { Presence of GW redox } \\
\text { conditions conducive to } \\
\text { compound persistence; } \\
\text { presence of natural hydraulic } \\
\text { gradients enhancing downward } \\
\text { GW movement; pumping- } \\
\text { enhanced downward and (or) } \\
\text { horizontal movement of GW } \\
\text { containing VOCs; large sources } \\
\text { of potential artificial recharge } \\
\text { and associated high modern } \\
\text { recharge rates and young GW } \\
\text { ages }\end{array}$ \\
\hline
\end{tabular}


Table 11. For each of the 15 case-study basins in the Southwest Principal Aquifers study area, locations where $A$, volatile organic compounds, and $B$, pesticide compounds, which have primarily human sources, have been detected in groundwater and associated sources and hydrogeologic controls.-Continued

\section{A. Volatile organic compounds}

\begin{tabular}{|c|c|c|c|c|c|c|}
\hline \multirow[b]{2}{*}{ Basin } & \multicolumn{2}{|c|}{$\begin{array}{c}\text { Location(s) within groundwater flow } \\
\text { system }\end{array}$} & \multirow{2}{*}{$\begin{array}{l}\text { Types of VOCs } \\
\text { observed }\end{array}$} & \multirow{2}{*}{$\begin{array}{l}\text { Observed } \\
\text { concentrations of } \\
\text { VOCs }\end{array}$} & \multirow[b]{2}{*}{ Human source(s) } & \multirow[b]{2}{*}{ Primary hydrogeologic control(s) } \\
\hline & $\begin{array}{l}\text { Areal location(s) } \\
\text { where VOCs have } \\
\text { been detected }\end{array}$ & $\begin{array}{c}\text { Vertical Iocation(s) } \\
\text { where VOCs ave } \\
\text { been detected }\end{array}$ & & & & \\
\hline San Jacinto & Much of basin & $\begin{array}{l}\text { Most depths, } \\
\text { although more } \\
\text { frequently detected } \\
\text { in shallower } \\
\text { rather than deeper } \\
\text { production wells }\end{array}$ & Chloroform, PCE & $\begin{array}{l}\text { Generally less } \\
\text { than } 1 \mu \mathrm{g} / \mathrm{L}\end{array}$ & $\begin{array}{l}\text { Chlorinated municipal-supply } \\
\text { water infiltrating through } \\
\text { irrigated yards/turf areas or } \\
\text { leaking from distribution pipes; } \\
\text { urban point sources that might } \\
\text { include landfills, leaky storage } \\
\text { tanks, spills, and (or) improper } \\
\text { disposal points in industrial, } \\
\text { commercial, and (or) military } \\
\text { settings }\end{array}$ & $\begin{array}{l}\text { Presence of GW redox } \\
\text { conditions conducive to } \\
\text { compound persistence and } \\
\text { presence of natural hydraulic } \\
\text { gradients enhancing downward } \\
\text { GW movement; large sources } \\
\text { of potential artificial recharge } \\
\text { and associated high modern } \\
\text { recharge rates and young GW } \\
\text { ages }\end{array}$ \\
\hline $\begin{array}{l}\text { San Luis } \\
\text { Valley }\end{array}$ & $\begin{array}{l}\text { Of } 35 \text { shallow wells } \\
\text { sampled, } 1 \text { VOC } \\
\text { detection beneath } \\
\text { the valley floor of } \\
\text { the San Luis closed } \\
\text { basin }\end{array}$ & Well depth $<25 \mathrm{ft}$ & $\begin{array}{l}\text { MTBE (a gasoline } \\
\text { oxygenate) }\end{array}$ & $0.6 \mu \mathrm{g} / \mathrm{L}$ & $\begin{array}{l}\text { Likely urban point source that } \\
\text { might include a leaky storage } \\
\text { tank or spill }\end{array}$ & $\begin{array}{l}\text { Presence of a shallow water table } \\
\text { in areas with large sources of } \\
\text { potential artificial recharge; } \\
\text { presence of confining units } \\
\text { inhibiting downward GW } \\
\text { movement }\end{array}$ \\
\hline $\begin{array}{l}\text { Santa Ana } \\
\text { Coastal }\end{array}$ & $\begin{array}{l}\text { Much of unconfined } \\
\text { part of basin }\end{array}$ & $\begin{array}{l}\text { Most depths, } \\
\text { although more } \\
\text { frequently detected } \\
\text { in shallower } \\
\text { rather than deeper } \\
\text { production wells } \\
\text { in unconfined part } \\
\text { of basin }\end{array}$ & $\begin{array}{l}\text { Chloroform, } \\
\text { 1,1,1-trichloro- } \\
\text { ethane (TCA), } \\
\text { MTBE }\end{array}$ & $\begin{array}{l}\text { Generally less } \\
\text { than } 1 \mu \mathrm{g} / \mathrm{L}\end{array}$ & $\begin{array}{l}\text { Urban point sources that might } \\
\text { include landfills, leaky storage } \\
\text { tanks, spills, and (or) improper } \\
\text { disposal points in industrial, } \\
\text { commercial, and (or) military } \\
\text { settings; chlorinated municipal- } \\
\text { supply water infiltrating through } \\
\text { irrigated yards/turf areas or } \\
\text { leaking from distribution pipes; } \\
\text { engineered recharge of urban } \\
\text { runoff or treated wastewater } \\
\text { through impoundments and } \\
\text { spreading facilities; urban runoff } \\
\text { infiltrating through streams, } \\
\text { through dry wells, and (or) as } \\
\text { diffuse recharge }\end{array}$ & $\begin{array}{l}\text { Presence of GW redox } \\
\text { conditions conducive to } \\
\text { compound persistence; } \\
\text { presence of natural hydraulic } \\
\text { gradients enhancing downward } \\
\text { GW movement; pumping- } \\
\text { enhanced downward and } \\
\text { (or) horizontal movement of } \\
\text { GW containing VOCs; large } \\
\text { sources of potential artificial } \\
\text { recharge and associated high } \\
\text { modern recharge rates and } \\
\text { young GW ages; high degree of } \\
\text { modification of the GW system } \\
\text { (recharge and discharge), } \\
\text { resulting in increased flow rates } \\
\text { and mixing }\end{array}$ \\
\hline $\begin{array}{l}\text { Santa Ana } \\
\text { Inland }\end{array}$ & Much of basin & $\begin{array}{l}\text { Most depths, } \\
\text { although more } \\
\text { frequently detected } \\
\text { in shallower } \\
\text { rather than deeper } \\
\text { production wells }\end{array}$ & $\begin{array}{l}\text { Chloroform, TCE, } \\
\text { PCE, DCE, } \\
\text { MTBE }\end{array}$ & $\begin{array}{l}\text { Generally less } \\
\text { than } 1 \mu \mathrm{g} / \mathrm{L} \\
\text { although } 3 \\
\text { production wells } \\
\text { sampled by } \\
\text { NAWQA had } \\
\text { concentrations } \\
>5 \mu \mathrm{g} / \mathrm{L}\end{array}$ & $\begin{array}{l}\text { Urban point sources that might } \\
\text { include landfills, leaky storage } \\
\text { tanks, spills, and (or) improper } \\
\text { disposal points in industrial, } \\
\text { commercial, and (or) military } \\
\text { settings; chlorinated municipal- } \\
\text { supply water infiltrating through } \\
\text { irrigated yards/turf areas or } \\
\text { leaking from distribution pipes; } \\
\text { urban runoff infiltrating through } \\
\text { streams, through dry wells, and } \\
\text { (or) as diffuse recharge }\end{array}$ & $\begin{array}{l}\text { Presence of GW redox } \\
\text { conditions conducive to } \\
\text { compound persistence; } \\
\text { presence of natural hydraulic } \\
\text { gradients enhancing downward } \\
\text { GW movement; large sources } \\
\text { of potential artificial recharge } \\
\text { and associated high modern } \\
\text { recharge rates and young GW } \\
\text { ages }\end{array}$ \\
\hline $\begin{array}{l}\text { Sierra Vista } \\
\text { subbasin }\end{array}$ & $\begin{array}{l}\text { A total of } 11 \text { of the } \\
87 \text { VOCs analyzed } \\
\text { were detected } \\
\text { among } 14 \text { of } 19 \\
\text { ( } 74 \text { percent of) } \\
\text { wells distributed } \\
\text { across the basin }\end{array}$ & $\begin{array}{l}\text { Depths up to at least } \\
\text { a couple hundred } \\
\text { feet below the } \\
\text { water table }\end{array}$ & $\begin{array}{l}\text { Gasoline } \\
\text { and related } \\
\text { hydrocarbons, } \\
\text { organic synthesis } \\
\text { compounds, } \\
\text { solvents, CFCs, } \\
\text { disinfection } \\
\text { by-products of } \\
\text { chlorination, } \\
\text { BTEX compounds }\end{array}$ & Generally $<5 \mu \mathrm{g} / \mathrm{L}$ & $\begin{array}{l}\text { Urban point sources that might } \\
\text { include landfills, leaky storage } \\
\text { tanks, spills, and (or) improper } \\
\text { disposal points in industrial, } \\
\text { commercial, and (or) military } \\
\text { settings; possible contributions } \\
\text { of some compounds from } \\
\text { chlorinated municipal-supply } \\
\text { water infiltrating through } \\
\text { irrigated yards/turf areas or } \\
\text { leaking from distribution pipes }\end{array}$ & $\begin{array}{l}\text { Possible presence of preferential } \\
\text { flow paths (such as wellbores) } \\
\text { between different aquifer } \\
\text { depths }\end{array}$ \\
\hline $\begin{array}{l}\text { Spanish } \\
\text { Springs Valley }\end{array}$ & $\begin{array}{l}\text { Localized within } \\
\text { central part of } \\
\text { basin }\end{array}$ & All depths & $\begin{array}{l}\text { THMs, gasoline } \\
\text { related } \\
\text { hydrocarbons }\end{array}$ & $\begin{array}{l}\text { Generally }<0.05 \\
\mu \mathrm{g} / \mathrm{L} \text { in deep } \\
\text { and }<0.4 \mu \mathrm{g} / \mathrm{L} \\
\text { shallow }\end{array}$ & $\begin{array}{l}\text { Chlorinated municipal-supply } \\
\text { water infiltrating through } \\
\text { irrigated yards/turf areas or } \\
\text { leaking from distribution pipes }\end{array}$ & $\begin{array}{l}\text { High degree of modification } \\
\text { of the GW system (recharge } \\
\text { and discharge), resulting } \\
\text { in increased flow rates and } \\
\text { mixing; presence of GW } \\
\text { redox conditions conducive to } \\
\text { compound persistence }\end{array}$ \\
\hline
\end{tabular}


Table 11. For each of the 15 case-study basins in the Southwest Principal Aquifers study area, locations where $A$, volatile organic compounds, and $B$, pesticide compounds, which have primarily human sources, have been detected in groundwater and associated sources and hydrogeologic controls.-Continued

\section{A. Volatile organic compounds}

\begin{tabular}{|c|c|c|c|c|c|c|}
\hline \multirow[b]{2}{*}{ Basin } & \multicolumn{2}{|c|}{$\begin{array}{l}\text { Location(s) within groundwater flow } \\
\text { system }\end{array}$} & \multirow{2}{*}{$\begin{array}{l}\text { Types of VOCs } \\
\text { observed }\end{array}$} & \multirow{2}{*}{$\begin{array}{l}\text { Observed } \\
\text { concentrations of } \\
\text { VOCs }\end{array}$} & \multirow[b]{2}{*}{ Human source(s) } & \multirow[b]{2}{*}{ Primary hydrogeologic control(s) } \\
\hline & $\begin{array}{l}\text { Areal location(s) } \\
\text { where VOCs have } \\
\text { been detected }\end{array}$ & $\begin{array}{l}\text { Vertical location(s) } \\
\text { where VOCs ave } \\
\text { been detected }\end{array}$ & & & & \\
\hline $\begin{array}{l}\text { Truckee } \\
\text { Meadows }\end{array}$ & $\begin{array}{l}\text { VOCs were detected } \\
\text { in } 19 \text { of } 28 \text { shallow } \\
\text { wells and } 10 \text { of } 18 \\
\text { deeper wells }\end{array}$ & All depths & $\begin{array}{l}\text { THMs, solvents, } \\
\text { gasoline } \\
\text { oxygenates }\end{array}$ & $\begin{array}{l}\text { Generally }<5 \\
\mu \mathrm{g} / \mathrm{L}, \text { although } \\
\text { several shallow } \\
\text { wells exceed } \\
10 \mu \mathrm{g} / \mathrm{L} \text {, with } \\
\text { observed } \\
\text { concentrations as } \\
\text { high as } 220 \mu \mathrm{g} / \mathrm{L}\end{array}$ & $\begin{array}{l}\text { Chlorinated municipal-supply } \\
\text { water infiltrating through } \\
\text { irrigated yards/turf areas or } \\
\text { leaking from distribution pipes; } \\
\text { urban point sources that might } \\
\text { include landfills, leaky storage } \\
\text { tanks, spills, and (or) improper } \\
\text { disposal points in industrial, } \\
\text { commercial, and (or) military } \\
\text { settings }\end{array}$ & $\begin{array}{l}\text { Pumping-enhanced downward } \\
\text { and (or) horizontal movement } \\
\text { of GW containing VOCs; } \\
\text { presence of GW redox } \\
\text { conditions conducive to } \\
\text { compound persistence }\end{array}$ \\
\hline $\begin{array}{l}\text { Upper Santa } \\
\text { Cruz }\end{array}$ & $\begin{array}{l}\text { A total of } 11 \text { of the } \\
86 \text { VOCs analyzed } \\
\text { were detected } \\
\text { among } 15 \text { of } 29 \\
\text { (52 percent of) } \\
\text { wells distributed } \\
\text { across the basin }\end{array}$ & $\begin{array}{l}\text { Depths up to at least } \\
\text { a couple hundred } \\
\text { feet below the } \\
\text { water table }\end{array}$ & $\begin{array}{l}\text { Disinfection } \\
\text { by-products of } \\
\text { chlorination, } \\
\text { fumigants, } \\
\text { solvents, } \\
\text { refrigerants, } \\
\text { BTEX } \\
\text { compounds, and } \\
\text { organic synthesis } \\
\text { compounds }\end{array}$ & Generally $<5 \mu \mathrm{g} / \mathrm{L}$ & $\begin{array}{l}\text { Possible sources include: urban } \\
\text { runoff infiltrating through } \\
\text { streams, through dry wells, } \\
\text { and (or) as diffuse recharge; } \\
\text { urban point sources that } \\
\text { might include landfills, leaky } \\
\text { storage tanks, spills, and (or) } \\
\text { improper disposal points in } \\
\text { industrial, commercial, and (or) } \\
\text { military settings; treated urban } \\
\text { wastewater infiltrating from } \\
\text { streams or through irrigated } \\
\text { fields; chlorinated municipal- } \\
\text { supply water infiltrating through } \\
\text { irrigated yards/turf areas or } \\
\text { leaking from distribution pipes }\end{array}$ & $\begin{array}{l}\text { Possible presence of preferential } \\
\text { flow paths (such as wellbores) } \\
\text { between different aquifer } \\
\text { depths }\end{array}$ \\
\hline \multirow[t]{2}{*}{$\begin{array}{l}\text { West Salt } \\
\text { River Valley }\end{array}$} & $\begin{array}{l}\text { A total of } 18 \text { VOCs } \\
\text { were detected } \\
\text { among } 21 \text { of } 30 \\
\text { ( } 70 \text { percent of }) \\
\text { wells distributed } \\
\text { across the basin }\end{array}$ & $\begin{array}{l}\text { Depths up to at least } \\
\text { a couple hundred } \\
\text { feet below the } \\
\text { water table }\end{array}$ & $\begin{array}{l}\text { Oxygenate } \\
\text { compounds, } \\
\text { BTEX } \\
\text { compounds, } \\
\text { CFCs, gasoline } \\
\text { related } \\
\text { hydrocarbons, } \\
\text { organic synthesis } \\
\text { compounds, } \\
\text { solvents, } \\
\text { refrigerants, } \\
\text { disinfection } \\
\text { by-product of } \\
\text { chlorination }\end{array}$ & $\begin{array}{l}\text { Generally }<5 \\
\mu \mathrm{g} / \mathrm{L} ; \text { may be } \\
\text { able to refine } \\
\text { number }\end{array}$ & $\begin{array}{l}\text { Possible sources include: urban } \\
\text { runoff infiltrating through } \\
\text { streams, through dry wells, } \\
\text { and (or) as diffuse recharge; } \\
\text { urban point sources that } \\
\text { might include landfills, leaky } \\
\text { storage tanks, spills, and (or) } \\
\text { improper disposal points in } \\
\text { industrial, commercial, and (or) } \\
\text { military settings; treated urban } \\
\text { wastewater infiltrating from } \\
\text { streams or through irrigated } \\
\text { fields; chlorinated municipal- } \\
\text { supply water infiltrating through } \\
\text { irrigated yards/turf areas or } \\
\text { leaking from distribution pipes }\end{array}$ & $\begin{array}{l}\text { Presence of confining units } \\
\text { inhibiting downward GW } \\
\text { movement; possible presence } \\
\text { of preferential flow paths (such } \\
\text { as wellbores) between different } \\
\text { aquifer depths; pumping- } \\
\text { enhanced downward and (or) } \\
\text { horizontal movement of GW } \\
\text { containing VOCs; high degree } \\
\text { of modification of the GW } \\
\text { system (recharge and discharge) }\end{array}$ \\
\hline & $\begin{array}{l}\text { A total of } 20 \text { VOCs } \\
\text { were detected } \\
\text { among } 9 \text { of } 9 \\
\text { (100 percent of) } \\
\text { wells located in an } \\
\text { agricultural setting }\end{array}$ & $\begin{array}{l}\text { Top } 10 \mathrm{ft} \text { of the } \\
\text { aquifer }\end{array}$ & $\begin{array}{l}\text { Trichloromethane } \\
\text { (also known } \\
\text { as chloroform) } \\
\text { was the most } \\
\text { commonly } \\
\text { detected VOC, } \\
\text { followed by PCE }\end{array}$ & Generally $<5 \mu \mathrm{g} / \mathrm{L}$ & $\begin{array}{l}\text { Possible sources include: treated } \\
\text { urban wastewater infiltrating } \\
\text { from streams or through } \\
\text { irrigated fields; urban runoff } \\
\text { infiltrating through streams, } \\
\text { through dry wells, and (or) as } \\
\text { diffuse recharge; urban point } \\
\text { sources that might include } \\
\text { landfills, leaky storage tanks, } \\
\text { spills, and (or) improper } \\
\text { disposal points in industrial, } \\
\text { commercial, and (or) military } \\
\text { settings; chlorinated municipal- } \\
\text { supply water infiltrating through } \\
\text { irrigated yards/turf areas or } \\
\text { leaking from distribution pipes }\end{array}$ & $\begin{array}{l}\text { Presence of confining units } \\
\text { inhibiting downward GW } \\
\text { movement; possible presence } \\
\text { of preferential flow paths (such } \\
\text { as wellbores) between different } \\
\text { aquifer depths; pumping- } \\
\text { enhanced downward and (or) } \\
\text { horizontal movement of GW } \\
\text { containing VOCs }\end{array}$ \\
\hline
\end{tabular}


Table 11. For each of the 15 case-study basins in the Southwest Principal Aquifers study area, locations where $A$, volatile organic compounds, and $B$, pesticide compounds, which have primarily human sources, have been detected in groundwater and associated sources and hydrogeologic controls.-Continued

\section{B. Pesticides}

\begin{tabular}{|c|c|c|c|c|c|c|}
\hline \multirow[b]{2}{*}{ Basin } & \multicolumn{2}{|c|}{ Location(s) within ground-water flow system } & \multirow[b]{2}{*}{$\begin{array}{l}\text { Types of pesticide } \\
\text { compounds observed }\end{array}$} & \multirow[b]{2}{*}{$\begin{array}{l}\text { Observed } \\
\text { concentrations } \\
\text { of pesticide } \\
\text { compounds }\end{array}$} & \multirow[b]{2}{*}{ Human source(s) } & \multirow[b]{2}{*}{$\begin{array}{l}\text { Primary hydrogeologic } \\
\text { control(s) }\end{array}$} \\
\hline & $\begin{array}{c}\text { Areal location(s) } \\
\text { where pesticide } \\
\text { compounds have been } \\
\text { detected }\end{array}$ & $\begin{array}{c}\text { Vertical location(s) } \\
\text { where pesticide } \\
\text { compounds have been } \\
\text { detected }\end{array}$ & & & & \\
\hline Carson Valley & Few detections & Not assessed & No data & No data & Unknown/not assessed & Unknown/not assessed \\
\hline Central Valley & $\begin{array}{l}\text { Much of basin, more } \\
\text { frequently on the } \\
\text { eastern side of the } \\
\text { San Joaquin Valley } \\
\text { where most recharge } \\
\text { occurs }\end{array}$ & $\begin{array}{l}\text { Most depths, although } \\
\text { more frequently } \\
\text { detected in shallower } \\
\text { rather than deeper } \\
\text { production wells in } \\
\text { unconfined part of } \\
\text { basin }\end{array}$ & $\begin{array}{l}\text { Agricultural and } \\
\text { non-agricultural } \\
\text { herbicides and (or) } \\
\text { their degradates } \\
\text { (including } \\
\text { simazine, atrazine, } \\
\text { deethylatrazine, } \\
\text { diuron, bentazon, } \\
\text { and the soil fumigant } \\
\text { 1,2-dibromo-3- } \\
\text { chloropropane } \\
\text { (DBCP)) }\end{array}$ & $\begin{array}{l}\text { Generally }<1 \\
\mu \mathrm{g} / \mathrm{L} \text {, except } \\
\text { for bentazon in } \\
\text { the Sacramento } \\
\text { Valley and } \\
\text { DBCP in the San } \\
\text { Joaquin Valley }\end{array}$ & $\begin{array}{l}\text { Agricultural irrigation } \\
\text { water infiltrating through } \\
\text { canals and (or) fields } \\
\text { where pesticides have } \\
\text { been applied; municipal- } \\
\text { supply water infiltrating } \\
\text { through yards/turf areas } \\
\text { where pesticides have } \\
\text { been applied; urban } \\
\text { runoff infiltrating through } \\
\text { streams, through dry } \\
\text { wells, and (or) as diffuse } \\
\text { recharge }\end{array}$ & $\begin{array}{l}\text { Presence of GW redox } \\
\text { conditions conducive to } \\
\text { compound persistence; } \\
\text { pumping-enhanced } \\
\text { downward and (or) } \\
\text { horizontal movement of GW } \\
\text { containing pesticides; high } \\
\text { degree of modification of } \\
\text { the GW system (recharge } \\
\text { and discharge), resulting } \\
\text { in increased flow rates and } \\
\text { mixing }\end{array}$ \\
\hline Eagle Valley & $\begin{array}{l}11 \text { of } 23 \text { wells had a } \\
\text { pesticide detection in } \\
\text { northeastern part of } \\
\text { the basin }\end{array}$ & $\begin{array}{l}\text { Depths less than } 500 \mathrm{ft} \\
\text { from land surface }\end{array}$ & $\begin{array}{l}\text { Herbicides likely } \\
\text { for mostly non- } \\
\text { agricultural uses } \\
\text { (atrazine and its } \\
\text { degradation product } \\
\text { deethylatrazine) }\end{array}$ & $\begin{array}{l}\text { Generally } \\
<1.2 \mu \mathrm{g} / \mathrm{L}\end{array}$ & $\begin{array}{l}\text { Municipal-supply water } \\
\text { infiltrating through } \\
\text { yards/turf areas where } \\
\text { pesticides have been } \\
\text { applied; treated urban } \\
\text { wastewater infiltrating } \\
\text { through irrigated fields }\end{array}$ & $\begin{array}{l}\text { Presence of natural hydraulic } \\
\text { gradients inhibiting } \\
\text { downward GW movement; } \\
\text { presence of GW redox } \\
\text { conditions conducive to } \\
\text { compound persistence }\end{array}$ \\
\hline $\begin{array}{l}\text { Las Vegas } \\
\text { Valley }\end{array}$ & $\begin{array}{l}\text { Localized urban valley } \\
\text { floor areas; } 5 \text { of } 32 \\
\text { shallow wells and } 2 \\
\text { of } 22 \text { deep wells }\end{array}$ & All depths & $\begin{array}{l}\text { Non-agricultural } \\
\text { herbicides including } \\
\text { atrazine and } \\
\text { prometon }\end{array}$ & $<0.05 \mu \mathrm{g} / \mathrm{L}$ & $\begin{array}{l}\text { Municipal-supply water } \\
\text { infiltrating through } \\
\text { yards/turf areas where } \\
\text { pesticides have been } \\
\text { applied }\end{array}$ & $\begin{array}{l}\text { Presence of confining units } \\
\text { inhibiting downward GW } \\
\text { movement; presence of } \\
\text { a shallow water table in } \\
\text { areas with large sources of } \\
\text { potential artificial recharge; } \\
\text { presence of GW redox } \\
\text { conditions conducive to } \\
\text { compound persistence; high } \\
\text { degree of modification of } \\
\text { the GW system (recharge } \\
\text { and discharge), resulting } \\
\text { in increased flow rates and } \\
\text { mixing }\end{array}$ \\
\hline \multirow[t]{2}{*}{$\begin{array}{l}\text { Middle Rio } \\
\text { Grande }\end{array}$} & $\begin{array}{l}\text { Localized areas of the } \\
\text { Rio Grande inner } \\
\text { valley }\end{array}$ & $\begin{array}{l}\text { Primarily shallow } \\
\text { groundwater (depths } \\
<100 \mathrm{ft} \text { ); occasional } \\
\text { detections up to a } \\
\text { couple hundred feet } \\
\text { below the water table }\end{array}$ & $\begin{array}{l}\text { Agricultural and } \\
\text { non-agricultural } \\
\text { herbicides and } \\
\text { insecticides, and } \\
\text { (or) their degradates } \\
\text { (including atrazine, } \\
\text { carbaryl, metolachlor, } \\
\text { prometon) }\end{array}$ & $\begin{array}{l}\text { Generally } \\
<1 \mu \mathrm{g} / \mathrm{L}\end{array}$ & $\begin{array}{l}\text { Agricultural irrigation } \\
\text { water infiltrating through } \\
\text { canals and (or) fields } \\
\text { where pesticides have } \\
\text { been applied; likely urban } \\
\text { runoff infiltrating as } \\
\text { diffuse recharge }\end{array}$ & $\begin{array}{l}\text { Presence of a shallow } \\
\text { water table in areas with } \\
\text { large sources of potential } \\
\text { artificial recharge; pumping- } \\
\text { enhanced downward and } \\
\text { (or) horizontal movement of } \\
\text { GW containing pesticides; } \\
\text { high degree of modification } \\
\text { of the GW system (recharge } \\
\text { and discharge), resulting } \\
\text { in increased flow rates and } \\
\text { mixing }\end{array}$ \\
\hline & $\begin{array}{l}\text { Very localized } \\
\text { areas outside but } \\
\text { generally near the Rio } \\
\text { Grande inner valley, } \\
\text { particularly in and } \\
\text { near Albuquerque } \\
\text { (unpublished USGS } \\
\text { data) }\end{array}$ & $\begin{array}{l}\text { Depths up to at least a } \\
\text { couple hundred feet } \\
\text { below the water table }\end{array}$ & $\begin{array}{l}\text { Agricultural and } \\
\text { non-agricultural } \\
\text { herbicides and } \\
\text { insecticides, and } \\
\text { (or) their degradates } \\
\text { (including atrazine, } \\
\text { deethylatrazine, } \\
\text { dieldrin, metolachlor, } \\
\text { simazine) }\end{array}$ & $\begin{array}{l}\text { Generally } \\
<1 \mu \mathrm{g} / \mathrm{L}\end{array}$ & $\begin{array}{l}\text { Possible municipal-supply } \\
\text { water infiltrating through } \\
\text { yards/turf areas where } \\
\text { pesticides have been } \\
\text { applied; possible urban } \\
\text { runoff infiltrating through } \\
\text { streams and (or) as } \\
\text { diffuse recharge }\end{array}$ & $\begin{array}{l}\text { Pumping-enhanced downward } \\
\text { and (or) horizontal } \\
\text { movement of GW containing } \\
\text { pesticides; possible presence } \\
\text { of preferential flow paths } \\
\text { (such as wellbores) between } \\
\text { different aquifer depths }\end{array}$ \\
\hline
\end{tabular}


Table 11. For each of the 15 case-study basins in the Southwest Principal Aquifers study area, locations where $A$, volatile organic compounds, and $B$, pesticide compounds, which have primarily human sources, have been detected in groundwater and associated sources and hydrogeologic controls. - Continued

\section{B. Pesticides}

\begin{tabular}{|c|c|c|c|c|c|}
\hline \multirow[b]{2}{*}{ Basin } & \multicolumn{2}{|c|}{ Location(s) within ground-water flow system } & \multirow[b]{2}{*}{$\begin{array}{l}\text { Types of pesticide } \\
\text { compounds observed }\end{array}$} & \multirow[b]{2}{*}{$\begin{array}{l}\text { Observed } \\
\text { concentrations } \\
\text { of pesticide } \\
\text { compounds }\end{array}$} & \multirow[b]{2}{*}{ Human source(s) } \\
\hline & $\begin{array}{c}\text { Areal location(s) } \\
\text { where pesticide } \\
\text { compounds have been } \\
\text { detected }\end{array}$ & $\begin{array}{c}\text { Vertical location(s) } \\
\text { where pesticide } \\
\text { compounds have been } \\
\text { detected }\end{array}$ & & & \\
\hline \multirow[t]{2}{*}{$\begin{array}{l}\text { Salt Lake } \\
\text { Valley }\end{array}$} & $\begin{array}{l}\text { Broad areas of the } \\
\text { valley with recent } \\
\text { residential land use }\end{array}$ & $\begin{array}{c}\text { Detected in } 28 \text { of } 30 \\
\text { shallow monitoring } \\
\text { wells sampled by } \\
\text { NAWQA in valley }\end{array}$ & $\begin{array}{l}\text { Agricultural and } \\
\text { non-agricultural } \\
\text { herbicides and (or) } \\
\text { their degradates } \\
\text { (including atrazine, } \\
\text { deethylatrazine, } \\
\text { simazine) }\end{array}$ & $\begin{array}{l}\text { Generally } \\
<0.1 \mu \mathrm{g} / \mathrm{L}\end{array}$ & $\begin{array}{l}\text { Agricultural irrigation } \\
\text { and municipal-supply } \\
\text { water infiltrating through } \\
\text { fields and yards/turf } \\
\text { areas where pesticides } \\
\text { have been applied; urban } \\
\text { runoff infiltrating through } \\
\text { streams and (or) as } \\
\text { diffuse recharge }\end{array}$ \\
\hline & $\begin{array}{l}\text { Broad areas, mainly on } \\
\text { west side of valley, } \\
\text { particularly in areas } \\
\text { with a component of } \\
\text { recent recharge and a } \\
\text { downward hydraulic } \\
\text { gradient }\end{array}$ & $\begin{array}{l}\text { Depths typically } \\
\text { accessed by domestic } \\
\text { and public-supply } \\
\text { wells }\end{array}$ & $\begin{array}{l}\text { Agricultural and } \\
\text { non-agricultural } \\
\text { herbicides and (or) } \\
\text { their degradates } \\
\text { (including atrazine, } \\
\text { deethylatrazine, } \\
\text { simazine) }\end{array}$ & $\begin{array}{l}\text { Generally } \\
<0.1 \mu \mathrm{g} / \mathrm{L}\end{array}$ & $\begin{array}{l}\text { Agricultural irrigation } \\
\text { and municipal-supply } \\
\text { water infiltrating through } \\
\text { fields and yards/turf } \\
\text { areas where pesticides } \\
\text { have been applied; urban } \\
\text { runoff infiltrating through } \\
\text { streams and (or) as } \\
\text { diffuse recharge }\end{array}$ \\
\hline
\end{tabular}

\begin{tabular}{|c|c|c|c|c|c|c|}
\hline San Jacinto & Much of basin & $\begin{array}{l}\text { Most depths, although } \\
\text { more frequently } \\
\text { detected in shallower } \\
\text { rather than deeper } \\
\text { production wells }\end{array}$ & $\begin{array}{l}\text { Agricultural and } \\
\text { non-agricultural } \\
\text { herbicides and (or) } \\
\text { their degradates } \\
\text { (including atrazine, } \\
\text { deethylatrazine, } \\
\text { simazine) }\end{array}$ & $\begin{array}{l}\text { Less than } 0.5 \mu \mathrm{g} / \mathrm{L} \\
\text { and generally } \\
\text { less than } 0.1 \\
\mu \mathrm{g} / \mathrm{L}\end{array}$ & $\begin{array}{l}\text { Agricultural irrigation } \\
\text { and municipal-supply } \\
\text { water infiltrating through } \\
\text { fields and yards/turf areas } \\
\text { where pesticides have } \\
\text { been applied }\end{array}$ & $\begin{array}{l}\text { Presence of GW redox } \\
\text { conditions conducive to } \\
\text { compound persistence; } \\
\text { presence of natural hydraulic } \\
\text { gradients enhancing } \\
\text { downward GW movement; } \\
\text { large sources of potential } \\
\text { artificial recharge and } \\
\text { associated high modern } \\
\text { recharge rates and young } \\
\text { GW ages }\end{array}$ \\
\hline San Luis Valley & $\begin{array}{l}\text { Localized areas both } \\
\text { within and south of } \\
\text { the San Luis closed } \\
\text { basin, primarily } \\
\text { beneath the valley } \\
\text { floor }\end{array}$ & $\begin{array}{l}\text { Depths generally } \\
<120 \mathrm{ft} \text { and above } \\
\text { the confining unit }\end{array}$ & $\begin{array}{l}\text { Agricultural and } \\
\text { non-agricultural } \\
\text { herbicides, } \\
\text { insecticides, and } \\
\text { fungicides, and (or) } \\
\text { their degradates } \\
\text { (including } \\
\text { chlorothalonil, } \\
\text { metolachlor, } \\
\text { metribuzin, p,p'- } \\
\text { DDE, prometon) }\end{array}$ & $\begin{array}{l}\text { Generally } \\
<5 \mu \mathrm{g} / \mathrm{L}\end{array}$ & $\begin{array}{l}\text { Agricultural irrigation } \\
\text { water infiltrating through } \\
\text { canals and (or) fields } \\
\text { where pesticides have } \\
\text { been applied; possible } \\
\text { runoff from non- } \\
\text { agricultural (but not } \\
\text { necessarily urban) areas } \\
\text { infiltrating as diffuse } \\
\text { recharge }\end{array}$ & $\begin{array}{l}\text { Presence of a shallow water } \\
\text { table in areas with large } \\
\text { sources of potential artificial } \\
\text { recharge; presence of } \\
\text { confining units inhibiting } \\
\text { downward GW movement }\end{array}$ \\
\hline $\begin{array}{l}\text { Santa Ana } \\
\text { Coastal }\end{array}$ & $\begin{array}{l}\text { Localized areas, } \\
\text { mainly in unconfined } \\
\text { part of basin where } \\
\text { recharge occurs }\end{array}$ & Not well defined & $\begin{array}{l}\text { Agricultural and } \\
\text { non-agricultural } \\
\text { herbicides and (or) } \\
\text { their degradates } \\
\text { (including } \\
\text { atrazine, simazine, } \\
\text { deethylatrazine, } \\
\text { tebuthiuron) }\end{array}$ & $\begin{array}{l}\text { Less than } 0.5 \mu \mathrm{g} / \mathrm{L} \\
\text { and generally } \\
\text { less than } 0.1 \\
\mu \mathrm{g} / \mathrm{L}\end{array}$ & $\begin{array}{l}\text { Urban runoff infiltrating } \\
\text { through streams and } \\
\text { (or) as diffuse recharge; } \\
\text { engineered recharge of } \\
\text { urban runoff or treated } \\
\text { wastewater through } \\
\text { impoundments and } \\
\text { spreading facilities; } \\
\text { agricultural irrigation } \\
\text { and municipal-supply } \\
\text { water infiltrating through } \\
\text { fields and yards/turf areas } \\
\text { where pesticides have } \\
\text { been applied }\end{array}$ & $\begin{array}{l}\text { Presence of GW redox } \\
\text { conditions conducive to } \\
\text { compound persistence; } \\
\text { presence of natural hydraulic } \\
\text { gradients enhancing } \\
\text { downward GW movement; } \\
\text { large sources of potential } \\
\text { artificial recharge and } \\
\text { associated high modern } \\
\text { recharge rates and young } \\
\text { GW ages; high degree of } \\
\text { modification of the GW } \\
\text { system (recharge and } \\
\text { discharge), resulting in } \\
\text { increased flow rates and } \\
\text { mixing }\end{array}$ \\
\hline
\end{tabular}


Table 11. For each of the 15 case-study basins in the Southwest Principal Aquifers study area, locations where $A$, volatile organic compounds, and $B$, pesticide compounds, which have primarily human sources, have been detected in groundwater and associated sources and hydrogeologic controls.-Continued

\section{B. Pesticides}

\begin{tabular}{|c|c|c|c|c|c|c|}
\hline \multirow[b]{2}{*}{ Basin } & \multicolumn{2}{|c|}{ Location(s) within ground-water flow system } & \multirow[b]{2}{*}{$\begin{array}{l}\text { Types of pesticide } \\
\text { compounds observed }\end{array}$} & \multirow[b]{2}{*}{$\begin{array}{l}\text { Observed } \\
\text { concentrations } \\
\text { of pesticide } \\
\text { compounds }\end{array}$} & \multirow[b]{2}{*}{ Human source(s) } & \multirow[b]{2}{*}{$\begin{array}{c}\text { Primary hydrogeologic } \\
\text { control(s) }\end{array}$} \\
\hline & $\begin{array}{c}\text { Areal location(s) } \\
\text { where pesticide } \\
\text { compounds have been } \\
\text { detected }\end{array}$ & $\begin{array}{l}\text { Vertical location(s) } \\
\text { where pesticide } \\
\text { compounds have been } \\
\text { detected }\end{array}$ & & & & \\
\hline $\begin{array}{l}\text { Santa Ana } \\
\text { Inland }\end{array}$ & Much of basin & $\begin{array}{l}\text { Most depths, although } \\
\text { more frequently } \\
\text { detected in shallower } \\
\text { rather than deeper } \\
\text { production wells }\end{array}$ & $\begin{array}{l}\text { Agricultural and } \\
\text { non-agricultural } \\
\text { herbicides and (or) } \\
\text { their degradates } \\
\text { (including atrazine, } \\
\text { deethylatrazine, } \\
\text { simazine) }\end{array}$ & $\begin{array}{l}\text { Generally }<0.5 \\
\mu \mathrm{g} / \mathrm{L}\end{array}$ & $\begin{array}{l}\text { Agricultural irrigation } \\
\text { and municipal-supply } \\
\text { water infiltrating through } \\
\text { fields and yards/turf areas } \\
\text { where pesticides have } \\
\text { been applied }\end{array}$ & $\begin{array}{l}\text { Presence of GW redox } \\
\text { conditions conducive to } \\
\text { compound persistence; } \\
\text { presence of natural hydraulic } \\
\text { gradients enhancing } \\
\text { downward GW movement; } \\
\text { application of urban } \\
\text { recharge to areas of previous } \\
\text { agricultural activity; large } \\
\text { sources of potential artificial } \\
\text { recharge and associated high } \\
\text { modern recharge rates and } \\
\text { young GW ages }\end{array}$ \\
\hline
\end{tabular}

\begin{tabular}{|c|c|c|c|c|c|c|}
\hline $\begin{array}{l}\text { Sierra Vista } \\
\text { subbasin }\end{array}$ & $\begin{array}{l}\text { No pesticide } \\
\text { compounds were } \\
\text { detected in } 19 \text { wells } \\
\text { distributed across the } \\
\text { basin }\end{array}$ & $\begin{array}{l}\text { Not applicable } \\
\text { - pesticides not } \\
\text { detected }\end{array}$ & None observed & $\begin{array}{l}\text { Not applicable } \\
\text { - pesticides not } \\
\text { detected }\end{array}$ & $\begin{array}{l}\text { Pesticide usage in basin is } \\
\text { small because of minimal } \\
\text { agricultural and urban } \\
\text { land use in basin }\end{array}$ & $\begin{array}{l}\text { Not applicable - pesticides not } \\
\text { detected }\end{array}$ \\
\hline $\begin{array}{l}\text { Spanish } \\
\text { Springs Valley }\end{array}$ & $\begin{array}{l}\text { Western part of basin } \\
\text { near highway; } 1 \\
\text { public-supply well }\end{array}$ & $\begin{array}{l}\text { About } 200 \mathrm{ft} \text { from land } \\
\text { surface }\end{array}$ & $\begin{array}{l}\text { Agricultural and } \\
\text { non-agricultural } \\
\text { herbicides } \\
\text { (atrazine and its } \\
\text { degradation product } \\
\text { deethylatrazine) }\end{array}$ & $<0.05 \mu \mathrm{g} / \mathrm{L}$ & $\begin{array}{l}\text { Agricultural irrigation } \\
\text { water infiltrating through } \\
\text { fields where pesticides } \\
\text { have been applied }\end{array}$ & $\begin{array}{l}\text { High degree of modification } \\
\text { of the GW system (recharge } \\
\text { and discharge), resulting } \\
\text { in increased flow rates and } \\
\text { mixing; presence of GW } \\
\text { redox conditions conducive } \\
\text { to compound persistence }\end{array}$ \\
\hline $\begin{array}{l}\text { Truckee } \\
\text { Meadows }\end{array}$ & $\begin{array}{l}\text { Pesticides were } \\
\text { detected in } 19 \text { of } 28 \\
\text { shallow wells and } 8 \\
\text { of } 18 \text { deeper wells }\end{array}$ & All depths & $\begin{array}{l}\text { Agricultural and } \\
\text { non-agricultural } \\
\text { herbicides } \\
\text { (atrazine and its } \\
\text { degradation product } \\
\text { deethylatrazine, } \\
\text { prometon, and } \\
\text { simazine) }\end{array}$ & $\begin{array}{l}\text { Generally } \\
<0.1 \mu \mathrm{g} / \mathrm{L}\end{array}$ & $\begin{array}{l}\text { Agricultural irrigation } \\
\text { water infiltrating through } \\
\text { fields where pesticides } \\
\text { have been applied; } \\
\text { municipal-supply water } \\
\text { infiltrating through } \\
\text { yards/turf areas where } \\
\text { pesticides have been } \\
\text { applied; wastewater } \\
\text { leaking from urban sewer } \\
\text { pipes or infiltrating from } \\
\text { septic systems }\end{array}$ & $\begin{array}{l}\text { Pumping-enhanced downward } \\
\text { and (or) horizontal } \\
\text { movement of GW containing } \\
\text { pesticides; presence of GW } \\
\text { redox conditions conducive } \\
\text { to compound persistence }\end{array}$ \\
\hline $\begin{array}{l}\text { Upper Santa } \\
\text { Cruz }\end{array}$ & $\begin{array}{l}\text { Samples in } 8 \text { of the } 29 \\
\text { ( } 28 \text { percent of) wells } \\
\text { distributed across } \\
\text { the basin contained } \\
5 \text { of } 86 \text { pesticides } \\
\text { analyzed, indicating } \\
\text { some localized areas } \\
\text { of detection }\end{array}$ & $\begin{array}{l}\text { Depths up to at least a } \\
\text { couple hundred feet } \\
\text { below the water table }\end{array}$ & $\begin{array}{l}\text { Agricultural and } \\
\text { non-agricultural } \\
\text { herbicides } \\
\text { (atrazine and its } \\
\text { degradation product } \\
\text { deethylatrazine, as } \\
\text { well as prometon, } \\
\text { 2,4-D, and diuron) } \\
\text { and a fumigant (1,4 } \\
\text { dichlorobenzene) }\end{array}$ & $\begin{array}{l}\text { Generally } \\
<1 \mu \mathrm{g} / \mathrm{L}\end{array}$ & $\begin{array}{l}\text { Agricultural irrigation } \\
\text { water infiltrating through } \\
\text { canals and (or) fields } \\
\text { where pesticides have } \\
\text { been applied; municipal- } \\
\text { supply water infiltrating } \\
\text { through yards/turf areas } \\
\text { where pesticides have } \\
\text { been applied; urban } \\
\text { runoff infiltrating through } \\
\text { streams, through dry } \\
\text { wells, and (or) as diffuse } \\
\text { recharge; treated urban } \\
\text { wastewater infiltrating } \\
\text { from streams or through } \\
\text { irrigated fields }\end{array}$ & $\begin{array}{l}\text { Possible presence of } \\
\text { preferential flow paths } \\
\text { (such as wellbores) between } \\
\text { different aquifer depths; } \\
\text { possible presence of GW } \\
\text { redox conditions conducive } \\
\text { to compound persistence }\end{array}$ \\
\hline
\end{tabular}


Table 11. For each of the 15 case-study basins in the Southwest Principal Aquifers study area, locations where $A$, volatile organic compounds, and $B$, pesticide compounds, which have primarily human sources, have been detected in groundwater and associated sources and hydrogeologic controls. - Continued

\section{B. Pesticides}

\begin{tabular}{|c|c|c|c|c|c|c|}
\hline \multirow[b]{2}{*}{ Basin } & \multicolumn{2}{|c|}{ Location(s) within ground-water flow system } & \multirow[b]{2}{*}{$\begin{array}{l}\text { Types of pesticide } \\
\text { compounds observed }\end{array}$} & \multirow[b]{2}{*}{$\begin{array}{l}\text { Observed } \\
\text { concentrations } \\
\text { of pesticide } \\
\text { compounds }\end{array}$} & \multirow[b]{2}{*}{ Human source(s) } & \multirow[b]{2}{*}{$\begin{array}{l}\text { Primary hydrogeologic } \\
\text { control(s) }\end{array}$} \\
\hline & $\begin{array}{c}\text { Areal location(s) } \\
\text { where pesticide } \\
\text { compounds have been } \\
\text { detected }\end{array}$ & $\begin{array}{c}\text { Vertical location(s) } \\
\text { where pesticide } \\
\text { compounds have been } \\
\text { detected }\end{array}$ & & & & \\
\hline \multirow[t]{2}{*}{$\begin{array}{l}\text { West Salt River } \\
\text { Valley }\end{array}$} & $\begin{array}{l}\text { Samples in } 8 \text { of the } 35 \\
\text { ( } 23 \text { percent of) wells } \\
\text { distributed across } \\
\text { the basin contained } \\
8 \text { of } 86 \text { pesticides } \\
\text { analyzed }\end{array}$ & $\begin{array}{l}\text { Depths up to at least a } \\
\text { couple hundred feet } \\
\text { below the water table }\end{array}$ & $\begin{array}{l}\text { Agricultural and } \\
\text { non-agricultural } \\
\text { herbicides } \\
\text { (atrazine and its } \\
\text { degradation product } \\
\text { deethylatrazine, } \\
\text { as well as EPTC, } \\
\text { simazine, prometon, } \\
\text { acetochlor, triallate) } \\
\text { and agricultrual } \\
\text { insectide degradation } \\
\text { product (p,p'DDE) }\end{array}$ & $\begin{array}{l}\text { Generally } \\
<1 \mu \mathrm{g} / \mathrm{L}\end{array}$ & $\begin{array}{l}\text { Agricultural irrigation } \\
\text { water infiltrating through } \\
\text { canals and (or) fields } \\
\text { where pesticides have } \\
\text { been applied; municipal- } \\
\text { supply water infiltrating } \\
\text { through yards/turf areas } \\
\text { where pesticides have } \\
\text { been applied; urban } \\
\text { runoff infiltrating through } \\
\text { streams, through dry } \\
\text { wells, and (or) as diffuse } \\
\text { recharge; treated urban } \\
\text { wastewater infiltrating } \\
\text { from streams or through } \\
\text { irrigated fields }\end{array}$ & $\begin{array}{l}\text { Presence of confining units } \\
\text { inhibiting downward } \\
\text { GW movement; possible } \\
\text { presence of preferential flow } \\
\text { paths (such as wellbores) } \\
\text { between different aquifer } \\
\text { depths; pumping-enhanced } \\
\text { downward and (or) } \\
\text { horizontal movement of } \\
\text { GW containing pesticides; } \\
\text { possible presence of GW } \\
\text { redox conditions conducive } \\
\text { to compound persistence; } \\
\text { high degree of modification } \\
\text { of the GW system (recharge } \\
\text { and discharge) }\end{array}$ \\
\hline & $\begin{array}{l}\text { Ten of the } 86 \\
\text { pesticides analyzed } \\
\text { were detected in } \\
\text { samples from } 9 \text { of } 9 \\
\text { ( } 100 \text { percent of) wells } \\
\text { in an agricultural } \\
\text { setting }\end{array}$ & $\begin{array}{l}\text { Depths up to at least a } \\
\text { couple hundred feet } \\
\text { below the water table }\end{array}$ & $\begin{array}{l}\text { Agricultural and } \\
\text { non-agricultural } \\
\text { herbicides } \\
\text { (atrazine and its } \\
\text { degradation product } \\
\text { deethylatrazine, as } \\
\text { well as simazine, } \\
\text { diuron, acetochlor, } \\
\text { prometon, } \\
\text { metribuzin, and } \\
\text { trifluralin) and } \\
\text { agricultrual } \\
\text { insectides and } \\
\text { degradation products } \\
\text { (p,p'DDE, dieldrin, } \\
\text { and chlorpyrifos) }\end{array}$ & $\begin{array}{l}\text { Generally } \\
<1 \mu \mathrm{g} / \mathrm{L}\end{array}$ & $\begin{array}{l}\text { Agricultural irrigation } \\
\text { water infiltrating through } \\
\text { canals and (or) fields } \\
\text { where pesticides have } \\
\text { been applied; treated } \\
\text { urban wastewater } \\
\text { infiltrating from streams } \\
\text { or through irrigated fields }\end{array}$ & $\begin{array}{l}\text { Presence of confining units } \\
\text { inhibiting downward } \\
\text { GW movement; possible } \\
\text { presence of preferential flow } \\
\text { paths (such as wellbores) } \\
\text { between different aquifer } \\
\text { depths; pumping-enhanced } \\
\text { downward and (or) } \\
\text { horizontal movement of } \\
\text { GW containing pesticides; } \\
\text { possible presence of GW } \\
\text { redox conditions conducive } \\
\text { to compound persistence; } \\
\text { high degree of modification } \\
\text { of the GW system (recharge } \\
\text { and discharge) }\end{array}$ \\
\hline
\end{tabular}

Case-study basins where large sources of artificial recharge and (or) high degrees of system modification are cited as contributing factors are the Central Valley, Las Vegas Valley, Middle Rio Grande, Salt Lake Valley, San Jacinto, Santa Ana Coastal, Santa Ana Inland, Spanish Springs Valley, and West Salt River Valley. All these basins have modern recharge that is more than double predevelopment recharge (fig. 18) or have annual artificial recharge of about 3 in. or more per unit area. Case-study basins where large quantities of groundwater pumping are cited as contributing factors are the Middle Rio Grande, Salt Lake Valley, Santa Ana Coastal, Truckee Meadows, and West Salt River Valley, three of which have groundwater pumping accounting for more than half of modern discharge (fig. 18). In addition, the presence of deep wellbores and (or) long well screens that can act as preferential flow paths between different aquifer depths are listed as potentially important hydrogeologic controls in four basins (Middle Rio Grande, Sierra Vista subbasin, Upper Santa Cruz, and West Salt River Valley). In three basins (Las Vegas Valley, Middle Rio Grande, and San Luis Valley), the presence of a shallow water table in areas where substantial quantities of artificial recharge are applied is listed as an important hydrogeologic control.
Overall, findings from the 15 case-study basins suggest that VOC detections in groundwater of Southwestern alluvial basins commonly are areally and (or) vertically extensive, even in less urbanized basins. The detection of VOCs in several wells extending beyond the shallow aquifer in 12 basins suggests that VOCs are commonly of concern for use of the deeper groundwater resource in terms of indicating human-related effects on water quality, although documented VOC concentrations in deeper parts of the aquifer typically have been below human-health benchmarks. VOCs belonging to several different compound groups have been detected, which is indicative of the impact of multiple urban recharge sources, including infiltrating municipal-supply water that has been chlorinated, urban point sources of various types, and infiltrating wastewater. Extensive human modifications of the hydrologic system are believed to have influenced the distribution of VOCs in nearly two-thirds of the 15 case-study basins. Natural hydrogeologic controls are occasionally cited as providing some measure of protection to the aquifer (particularly at greater depths) but are more commonly cited as contributing to persistence and downward migration of VOCs. 


\section{Pesticide Compounds}

Organic compounds that are used to kill or control weeds, insects, rodents, or other unwanted organisms can be grouped into a general contaminant class known as pesticides. Gilliom and others (2006) discuss the specific pesticides that have been included in assessments conducted by NAWQA. These assessments have focused primarily on herbicides and insecticides (used against weeds and insects, respectively), including pesticides used primarily in agricultural areas, primarily in urban areas, or in both settings. NAWQA assessments also have included selected degradates - most notably deethylatrazine (a breakdown product of the herbicide atrazine). Similar to VOCs, pesticides differ in terms of the redox conditions under which they persist. The USEPA has established primary drinking-water standards for 21 pesticide compounds (pesticides and degradates); for several of these compounds, the drinking-water standard has been set at $5 \mu \mathrm{g} / \mathrm{L}$ or less (U.S. Environmental Protection Agency, 2009). For this discussion, all detections of pesticide compounds in groundwater are considered to be a potential cause for concern because detection at any concentration is indicative of vulnerability of that aquifer to human-related contamination. Information on observed pesticide concentrations is listed on table $11 \mathrm{~A}$, including an indicator of whether compounds might have been detected at concentrations known to be of concern for human health.

Pesticide compounds have been detected in at least part of the basin-fill aquifer in all case-study basins except the Sierra Vista subbasin and across broad areas of the basin-fill aquifer in six basins (Central Valley, Salt Lake Valley, San Jacinto, Santa Ana Inland, Truckee Meadows, and West Salt River Valley) (table 11B). Among the 14 basins where the distribution of pesticide detections with depth has been characterized, 9 have had detections throughout various depths, generally including depths where wells are completed for public supply. Only in Salt Lake Valley and San Luis Valley are the only basins where studies do not indicate several detections of pesticides beyond the shallow aquifer.

Findings with respect to the types of pesticides detected in groundwater of the 15 SWPA case-study basins were similar to findings of the nationwide NAWQA assessment by Gilliom and others (2006). The pesticides most commonly detected in the case-study basins were agricultural and (or) non-agricultural herbicides (13 basins). Pesticides of all other types were detected in three or fewer basins. Where detected, individual pesticides, regardless of type, were generally present at concentrations below $1 \mu \mathrm{g} / \mathrm{L}$, although higher concentrations were measured in some instances.

In all but 3 of the 14 case-study basins where pesticides have been detected in groundwater, infiltration of agricultural irrigation water through canals and (or) fields is listed as a primary human source contributing to pesticide detections in groundwater (fig. 17). Infiltration of agricultural irrigation water is listed as a primary source in basins with as little as about 1 percent agricultural land. Agricultural point sources resulting from spills during handling of pesticides also are possible but were not generally cited as major sources.

Urban recharge sources are listed as primary contributors to pesticide detections in groundwater in 11 basins (fig. 17). Therefore, of the 13 basins where pesticides have been detected and enough information is available to determine sources, only 2 do not have important urban sources. The most commonly listed urban source is urban irrigation water (11 basins), with urban runoff listed for 7 basins. In the San Luis Valley, non-agricultural (but not necessarily urban) runoff is listed as a source because of the detection of a nonagricultural herbicide that was likely used in non-crop areas of primarily agricultural land use, rather than in actual urban settings, which cover only about 2 percent of the basin. This same source might also be important in other basins. Other urban sources that can contribute various types of pesticides include treated urban wastewater infiltrating through streams or fields (listed for three basins), wastewater leaking from sewer or septic systems (listed for one basin), and engineered recharge (listed for one basin).

The primary hydrogeologic controls on the locations and depths where pesticides have been detected in the basin-fill aquifers of 14 case-study basins include natural and humanrelated processes/characteristics. As mentioned previously, a natural control of likely importance in contributing to pesticide persistence is the redox conditions in the aquifer, which are listed as a factor in 11 basins. More oxic conditions were shown by Paul and others (2007) to be associated with generally higher detection frequencies for several of the pesticide compounds most commonly detected at shallow depths in Southwestern basin-fill aquifers. Another natural control important to the distribution of pesticides in eight basins is the direction of natural vertical hydraulic gradients. In four basins (Salt Lake Valley, San Jacinto, Santa Ana Coastal, and Santa Ana Inland), natural downward gradients are listed as important in enhancing downward movement of pesticides that reach the water table in at least some areas; in five basins (Eagle Valley, Las Vegas Valley, Salt Lake Valley, San Luis Valley, and West Salt River Valley), natural upward gradients and (or) the existence of confining units are listed as important controls that help to protect the deeper (used) aquifer in at least some areas from contamination that is present in the shallower aquifer.

Human-related controls of importance in contributing to the distribution of pesticides in groundwater include the establishment of large sources of artificial recharge (resulting in increased modern recharge rates and younger overall groundwater ages), the initiation of large quantities of groundwater pumping (resulting in alteration of flow directions and gradients), and (or) the substantial modification of groundwater systems with respect to recharge and discharge processes (resulting in increased groundwater flow rates and mixing). Casestudy basins where large sources of artificial recharge, large quantities of groundwater pumping, and (or) high degrees of system modification are cited as contributing factors are the 
same basins where they were cited as contributing factors for VOCs: Central Valley, Las Vegas Valley, Middle Rio Grande, Salt Lake Valley, San Jacinto, Santa Ana Coastal, Santa Ana Inland, Spanish Springs Valley, and West Salt River Valley (fig. 18). In addition, the presence of deep wellbores that can act as preferential flow paths between different aquifer depths are listed as potentially important hydrogeologic controls in three basins. Also in three basins (Las Vegas Valley, Middle Rio Grande, and San Luis Valley), the presence of a shallow water table in areas where substantial quantities of artificial recharge are applied is listed as an important hydrogeologic control. In the Santa Ana Inland Basin, application of urban recharge to areas of previous agricultural activity is cited as a factor resulting in transport of pesticides to the aquifer.

Overall, findings from the 15 case-study basins suggest that pesticide detections in groundwater of Southwestern alluvial basins commonly are areally and (or) vertically extensive in areas of agricultural and (or) urban land use. The detection of pesticide compounds in several wells extending beyond the shallow aquifer in nine basins suggests that pesticides are generally of concern for use of the deeper groundwater resource in terms of indicating human-related effects on water quality, although documented pesticide concentrations in deeper parts of the aquifer typically have been below human-health benchmarks. Pesticides belonging to several different compound groups have been detected, which is indicative of the impact of multiple agricultural and non-agricultural/urban recharge sources. Extensive human modifications of the hydrologic system are believed to have influenced the distribution of pesticides in nearly two-thirds of the 14 case-study basins where pesticides have been detected. Natural hydrogeologic controls are occasionally cited as providing some measure of protection to the aquifer (particularly at greater depths) but are more commonly cited as contributing to persistence and downward migration of pesticides.

\section{Conceptual Models of Important Factors Affecting Vulnerability of Southwestern Basin-Fill Aquifers with Respect to Selected Contaminants}

On the basis of information presented in the "Factors with the Potential to Influence Aquifer Vulnerability and Their Variability Among Case-Study Basins" and "Synthesis of Contaminant Occurrence and Major Factors Affecting Aquifer Vulnerability in Case-Study Basins" sections of this report, conceptual models were developed to illustrate the most important factors likely to affect the vulnerability of Southwestern basin-fill aquifers to selected contaminants. These conceptual models are intended to provide a general understanding of major factors that should be considered in broad-scale characterization of aquifer vulnerability and to help guide future efforts at statistical modeling of contaminant occurrence. In this section, conceptual models are presented for the same six individual contaminants and (or) contaminant classes discussed in the "Synthesis of Contaminant Occurrence and Major Factors Affecting Aquifer Vulnerability in Case-Study Basins" section and presented in table 9. The conceptual models describe important sources and hydrogeologic processes relevant to each contaminant of interest as water moves from the land surface and unsaturated zone through the aquifer and to an individual well where the contaminant is measured, as illustrated in figures 19 through 24 and discussed separately below for each individual part of the flow path. Several of the important factors included in the conceptual models presented here can be characterized at a basin scale, which should allow for application of many aspects of the models even to Southwestern alluvial basins with sparse local-scale information.

It is important to note that not every potentially relevant factor (particularly of a localized nature) was considered in the analysis conducted for this report, including the development of the conceptual models. This is largely because either sufficient data generally were not available to adequately characterize the factor (for example, location and quantity of chemical use) or the factor provided more detail than was needed or desired for a general understanding of aquifer vulnerability (for example, crop type). However, some other factors were not included because they are common across essentially all Southwestern alluvial basins and, therefore, would not be useful in characterizing the relative vulnerability of different basins (or broad parts of basins) to contamination. For example, as discussed in "Factors with the Potential to Influence Aquifer Vulnerability and Their Variability Among Case-Study Basins," essentially all Southwestern alluvial basins have primarily relatively coarse soils with low organic content, relatively permeable aquifer sediments with similar ranges of hydraulic conductivity, and generally similar timeframes of agricultural and urban development. Additionally, the conceptual models presented in the text generally do not include factors of importance to only a minimal number of basins (although these factors are included on figures 19 through 24 as relevant but less important factors) to keep the models from becoming too complex for practical application. Finally, these conceptual models might not accurately capture all the most important factors determining aquifer vulnerability if the 15 SWPA case-study basins are not truly representative of sources and processes present across all Southwestern basinfill aquifers or if important factors in the individual case-study basins have not been accurately characterized in the current literature.

The factors included in the conceptual models as being most likely to affect the vulnerability of Southwestern basinfill aquifers to the six studied contaminants (or contaminant classes) are summarized in table 12. These are the factors that would be recommended for inclusion through appropriate variables in any assessment or statistical modeling of the vulnerability of Southwestern basin-fill aquifers with respect to these constituents. In table 12, an effort has been made to translate the relatively detailed individual sources and hydrogeologic factors listed in tables 9 through 11 into simplified 
Table 12. Potentially important factors recommended for inclusion in assessments/modeling of the vulerability of Southwestern alluvial basins to contamination with selected constituents.

[Factors that previous investigations in some alluvial basins have shown as likely to be important but that could not be adequately assessed for multiple casestudy basins with the currently available information are shown with a "(?)"]

\begin{tabular}{|c|c|c|c|c|}
\hline Constituent & Natural sources & Human sources & Natural hydrogeologic factors & Human factors \\
\hline \multirow[t]{3}{*}{ Dissolved solids } & $\begin{array}{l}\text { Presence of reactive rocks/sediments } \\
\text { within the recharge area }\end{array}$ & $\begin{array}{l}\text { Presence of agricultural sources } \\
\text { as a whole or individually }\end{array}$ & Rate of evapotranspiration & $\begin{array}{l}\text { Depth to water in areas of artificial } \\
\text { recharge }\end{array}$ \\
\hline & $\begin{array}{l}\text { Presence of reactive rocks/sediments } \\
\text { within the aquifer }\end{array}$ & $\begin{array}{l}\text { Presence of urban sources as a } \\
\text { whole or, for selected sources, } \\
\text { individually }\end{array}$ & $\begin{array}{l}\text { Presence of confining units and } \\
\text { (or) naturally upward hydraulic } \\
\text { gradients }\end{array}$ & $\begin{array}{l}\text { Contribution of artificial recharge to } \\
\text { overall basin groundwater budget }\end{array}$ \\
\hline & $\begin{array}{l}\text { Presence of saline (often geothermal) } \\
\text { water sources within or adjacent } \\
\text { to basin }\end{array}$ & & $\begin{array}{l}\text { Presence of faults and (or) } \\
\text { structural features enhancing } \\
\text { upward flow from depth }\end{array}$ & Magnitude of pumping stresses \\
\hline \multirow[t]{4}{*}{ Nitrate } & $\begin{array}{l}\text { Where known, presence of soil- } \\
\text { zone accumulations of nitrate } \\
\text { (resulting from natural physical } \\
\text { and biological processes) in areas } \\
\text { where recharge could periodically } \\
\text { occur }\end{array}$ & $\begin{array}{l}\text { Presence of agricultural sources } \\
\text { as a whole or individually }\end{array}$ & Rate of evapotranspiration & $\begin{array}{l}\text { Depth to water in areas of artificial } \\
\text { recharge }\end{array}$ \\
\hline & & $\begin{array}{l}\text { Presence of urban sources as a } \\
\text { whole or individually }\end{array}$ & Redox conditions & $\begin{array}{l}\text { Contribution of artificial recharge } \\
\text { to overall basin groundwater } \\
\text { budget }\end{array}$ \\
\hline & & & & Well depth \\
\hline & & & & $\begin{array}{l}\text { Presence of urban recharge in areas } \\
\text { of previous agriculture }\end{array}$ \\
\hline \multirow[t]{3}{*}{ Arsenic } & $\begin{array}{l}\text { Presence of high-arsenic rocks/sedi- } \\
\text { ments within the recharge area }\end{array}$ & None & Redox conditions (?) & None \\
\hline & $\begin{array}{l}\text { Presence of high-arsenic rocks/sedi- } \\
\text { ments within the aquifer }\end{array}$ & & pH values (?) & \\
\hline & $\begin{array}{l}\text { Presence of saline (often geothermal) } \\
\text { water sources within or adjacent } \\
\text { to basin (?) }\end{array}$ & & Groundwater residence time & \\
\hline Uranium & $\begin{array}{l}\text { Presence of high-uranium rocks/ } \\
\text { sediments within the recharge } \\
\text { area }\end{array}$ & None & Redox conditions & None \\
\hline \multirow{2}{*}{$\begin{array}{l}\text { Volatile organic } \\
\text { compounds }\end{array}$} & & & & Magnitude of pumping stresses \\
\hline & & & & Well depth \\
\hline \multirow[t]{4}{*}{$\begin{array}{l}\text { Pesticide com- } \\
\text { pounds }\end{array}$} & None & $\begin{array}{l}\text { Presence of agricultural sources } \\
\text { as a whole }\end{array}$ & $\begin{array}{l}\text { Presence of confining units and } \\
\text { (or) naturally upward hydrau- } \\
\text { lic gradients }\end{array}$ & $\begin{array}{l}\text { Depth to water in areas of artificial } \\
\text { recharge }\end{array}$ \\
\hline & & $\begin{array}{l}\text { Presence of urban sources as a } \\
\text { whole or individually }\end{array}$ & Redox conditions & $\begin{array}{l}\text { Contribution of artificial recharge } \\
\text { to overall basin groundwater } \\
\text { budget }\end{array}$ \\
\hline & & & & Magnitude of pumping stresses \\
\hline & & & & Well depth \\
\hline
\end{tabular}


variables that could be more readily characterized using available datasets. For example, rather than listing every potentially important type of urban recharge source, the table recommends use of data characterizing the presence of urban sources either individually or (if sources are not individually important or cannot be individually quantified) as a whole. Also, to represent extensive modification of the groundwater system with respect to recharge and (or) discharge, the table recommends use of data characterizing the contribution of artificial recharge to the overall basin groundwater budget and (or) data characterizing the magnitude of pumping stresses. In some cases noted in the table, certain sources or factors are recommended for inclusion in assessments/modeling on the basis of results of detailed hydrochemical studies that have been conducted in only one or two case-study basins (in combination with general knowledge from the literature). In these cases, the lack of inclusion of these factors for multiple basins in tables 9 through 11 is thought to indicate merely the lack of adequate assessment of these factors in available basin studies, rather than a lack of importance of the factors themselves.

\section{Contaminants with Important Natural and Human Sources}

\section{Dissolved Solids}

The conceptual model of major factors affecting the vulnerability of Southwestern basin-fill aquifers to contamination with dissolved solids is illustrated in figure 19 (natural factors are presented in figure 19A and human-related factors in figure 19B).

\section{Land Surface and Unsaturated Zone}

Both natural and human sources and processes that take place at or near the land surface are important to the vulnerability of Southwestern basin-fill aquifers to contamination with dissolved solids. With respect to natural sources and processes, relatively reactive rocks or sediments such as evaporites that are present at the land surface or in the unsaturated zone of recharge areas (primarily along basin margins) are commonly dissolved by precipitation or streams, resulting in increased dissolved-solids concentrations of water that ultimately recharges the aquifer. Evapotranspiration at the land surface or from the shallow soil zone can act to substantially further increase the dissolved-solids concentrations of recharging water. Importantly, evapotranspiration also increases the dissolvedsolids concentration of shallow groundwater in the discharge areas of Southwestern basin-fill aquifers, where riparian areas and (or) saline lakes commonly exist under natural conditions. Although likely relevant to only a few of the 15 case-study basins, where present, geothermal and (or) saline springs at the land surface can be a substantial source of recharge with high dissolved solids.

With respect to human activities at and near the land surface, the single most important factor affecting vulnerability of the aquifer to contamination with dissolved solids is the infiltration of excess agricultural irrigation water from fields and (or) conveyance channels, transporting solutes that have been concentrated by evapotranspiration. Agricultural wastewater infiltrating from disposal ponds is another agricultural source of somewhat lesser importance. Individual urban water sources that each contribute to increased dissolved-solids concentrations in the aquifers of a few case-study basins include municipal-supply water infiltrating through irrigated turf areas (where solutes in the infiltrating water are concentrated by evapotranspiration or by flushing of dissolved solids that had previously built up in the unsaturated zone); urban wastewater infiltrating from septic fields or leaky sewer lines; imported surface water infiltrating through streams, conveyance channels, or fields; and engineered recharge water. Although each of these urban sources is important to only a few basins, when taken as a whole, they are important in more than half of the case-study basins. In particular, groundwater dissolved-solids concentrations appear to be most substantially affected by urban activities in basins where modifications have been made to increase surface and (or) groundwater supplies, including importation of surface water or implementation of engineered recharge. Other than the presence of high evapotranspiration rates that concentrate solutes in artificial recharge, the primary near-surface hydrogeologic factor affecting aquifer vulnerability with respect to dissolved solids is the presence of a shallow water table (thin unsaturated zone) in areas where artificial recharge occurs. Where the unsaturated zone is thinner, less water needs to be applied to the land surface to result in aquifer recharge.

\section{Aquifer}

Both natural and human sources and processes are important to dissolved-solids concentrations once water has reached the aquifer. The most important factor appears to be natural dissolution of reactive rocks or sediments (such as gypsum) that are contacted by groundwater along a flow path. Although dissolution generally would be expected to progress to a greater degree along longer flow paths, groundwater residence time was cited as a primary factor resulting in elevated dissolved-solids concentrations in fewer than 20 percent of case-study basins. Instead, a more important factor appears to be the upward movement of saline water (of varying potential origin) from great depths into the used part of the aquifer as a result of faults or other structural features such as bedrock highs that either act directly as vertical conduits or that inhibit lateral flow at depth. Another factor of importance in several basins is the presence of confining units and (or) naturally upward hydraulic gradients that act to protect the used part of the aquifer from downward migration of shallow groundwater having elevated dissolved-solids concentrations as a result of near-surface sources or processes.

With respect to human-related factors that affect dissolved-solids concentrations of water once it has entered the aquifer, the two most important factors (combined affecting more than one third of case-study basins) relate to overall 


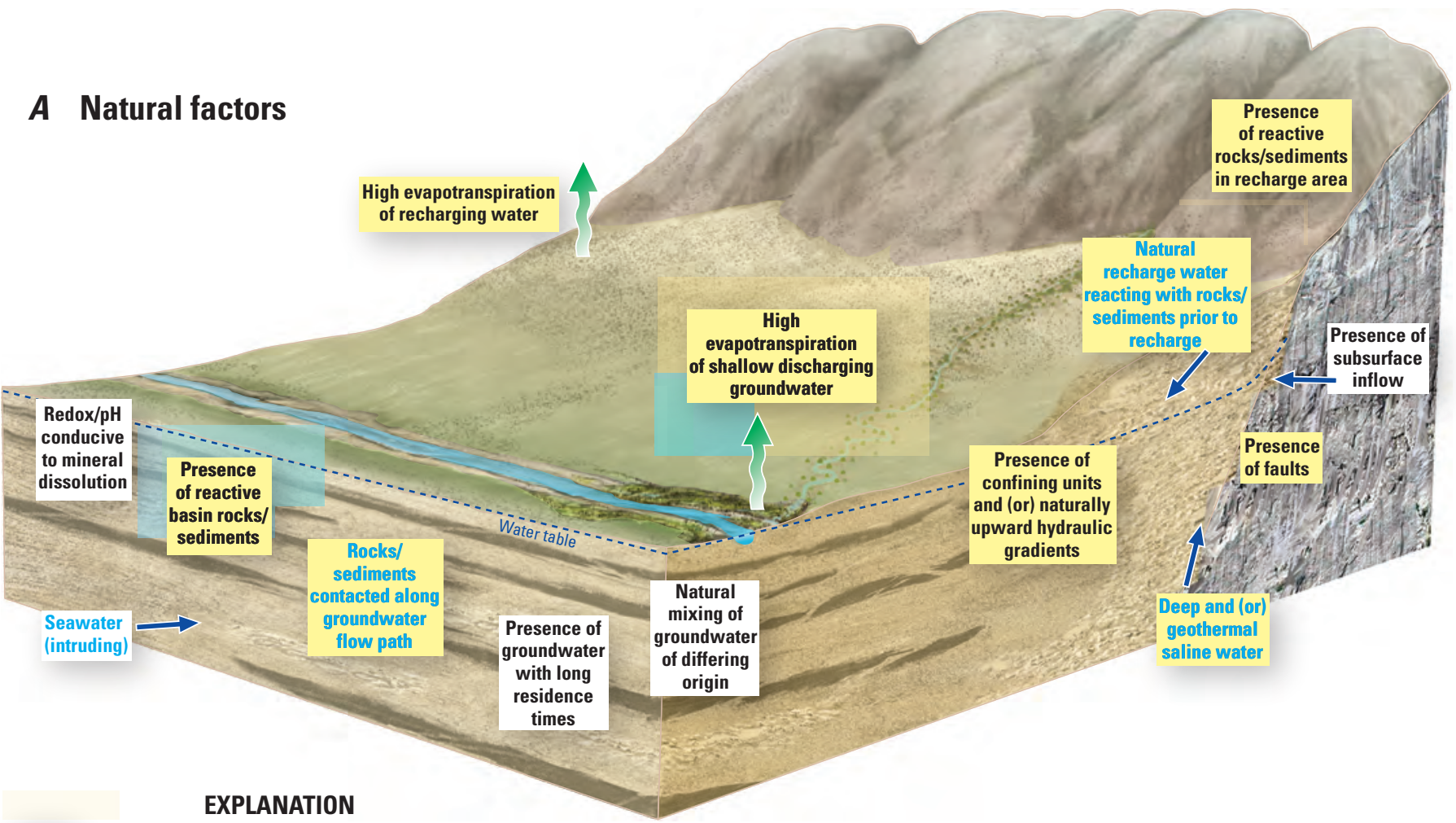

Contaminant source or hydrogeologic factor cited as being important in at least 20 percent of case-study basins

Contaminant source or hydrogeologic factor cited as being

important in fewer than 20 percent of case-study basins

Contaminant sources are shown in blue text

Hydrogeologic factors are shown in black text

\section{B Human factors}

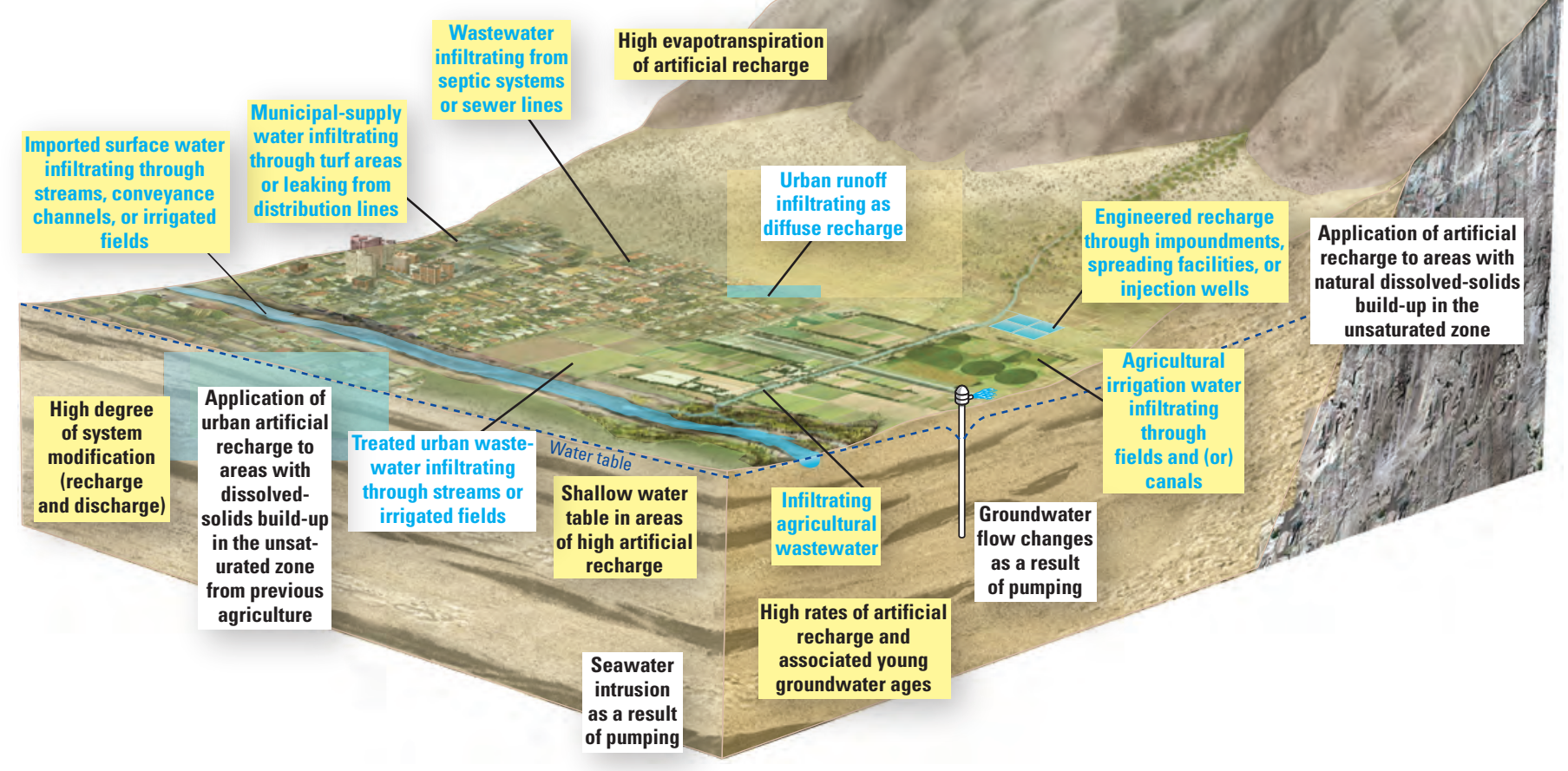

Figure 19. Conceptual model of major $A$, natural and $B$, human factors affecting the vulnerability of Southwestern basin-fill aquifers to contamination with dissolved solids. 
modification of the hydrologic system. In particular, the addition of a large quantity of artificial recharge (agricultural and (or) urban) to an aquifer increases the quantity of young water with potentially high dissolved-solids concentrations moving through the groundwater system and the rate at which that water travels. Combined modification of the mechanisms and quantities of recharge and discharge (with discharge modification typically being through the pumping of wells) also can substantially affect rates of groundwater flow, directions of groundwater flow, and mixing between waters of varying source and (or) age, thereby transporting water with high dissolved-solids concentrations horizontally and vertically to parts of the aquifer that would otherwise be unaffected.

\section{Well}

In most Southwestern basin-fill aquifers where dissolvedsolids concentrations are an issue, elevated concentrations have been observed at most or all depths of the aquifer, perhaps partly because sources are not located only or primarily at the land surface but also in the subsurface. Observation of elevated dissolved-solids concentrations across a wide range of depths indicates that wells used for domestic or public supply can be vulnerable to contamination. Wells screened beneath confining units or in areas of generally upward vertical gradients are, however, less likely to be affected by elevated dissolved-solids concentrations resulting from sources at the land surface. On the basis of the importance of hydrologic-system modification to the distribution of elevated dissolved-solids concentrations, higher-producing wells in areas of greater pumping stress would probably be more likely to eventually be affected by any existing high-dissolved-solids groundwater located nearby and (or) at shallow depths.

\section{Nitrate}

The conceptual model of major factors affecting the vulnerability of Southwestern basin-fill aquifers to contamination with nitrate is illustrated in figure 20 (natural factors are presented in figure 20A and human-related factors in figure 20B).

\section{Land Surface and Unsaturated Zone}

Although not as common as human sources, natural nitrate sources in the unsaturated zone have been documented to result in elevation of nitrate concentrations in some Southwestern basin-fill aquifers to levels of concern. This occurs through flushing of soil-zone accumulations likely resulting from long periods of high evapotranspiration of precipitation combined with minimal recharge through the soil profile and (or) from nitrification of ammonium produced by leguminous crops and nitrogen-fixing bacteria. Evapotranspiration of recharge water (often of artificial recharge water) is an important natural process at or near the land surface that contributes to elevated nitrate concentrations in groundwater.

Several types of human-related activities at the land surface introduce sources of nitrate that can ultimately contaminate groundwater. Excess irrigation water infiltrating from fertilized agricultural fields and (or) urban turf areas is among the most important sources of nitrate in the Southwestern alluvial basins. Nitrogen present in fertilizers used in agricultural and urban settings is quite soluble and mobile in the form of nitrate. Nitrate in excess of the amount used by the crops or turf to which fertilizer is applied can be readily transported by excess irrigation water through the relatively coarse soils of low organic-carbon content that are typical of most locations in the Southwestern alluvial basins. Urban wastewater infiltrating from septic fields or leaky sewer lines is another nitrate source of primary importance. Nitrogen in wastewater is readily converted to nitrate in the generally oxic conditions present in the unsaturated zone and aquifer. Other relatively common sources of nitrate to Southwestern basin-fill aquifers are agricultural wastewater infiltrating from disposal ponds, urban wastewater infiltrating through streams to which it is released or through fields to which it is applied, and diffuse urban runoff. Estimates of recent nitrogen inputs through fertilizer and manure (plus atmospheric deposition) are available (Ruddy and others, 2006) to help characterize nitrate contributions from agricultural activities and nonfarm fertilizer use, but these estimates of nitrogen input do not include contributions from other sources in areas of urban land use. Where urban recharge is occurring through areas of previous agricultural activity, nitrate remaining in the soil from previous fertilizer application also can be an important source to the aquifer. Other than the presence of high evapotranspiration rates that concentrate nitrate in artificial recharge, the primary near-surface hydrogeologic factor affecting aquifer vulnerability with respect to nitrate is the presence of a shallow water table (thin unsaturated zone) in areas where artificial recharge occurs.

Aquifer

The most important factor affecting nitrate concentrations in water that has reached the aquifer appears to be the natural redox conditions present. Oxic conditions are necessary for nitrate to form and persist. In groundwater, once dissolved oxygen has become substantially depleted by microbial activity, nitrate is favored by microorganisms for respiration, resulting in conversion of nitrate to nitrogen gas through denitrification. Nitrate attenuation capacity is believed to be relatively low in Southwestern basin-fill aquifers (McMahon and Chapelle, 2008), although denitrification can occur where the necessary electron donors (such as those supplied by organic matter) are present and might generally have progressed to a greater degree in older, deeper groundwater. Another natural hydrogeologic factor of importance in the distribution of nitrate in groundwater in several basins is the presence of confining units and (or) naturally upward hydraulic gradients that act to protect the used part of the aquifer from downward migration of shallow groundwater having elevated nitrate concentrations as a result of near-surface sources or processes.

As with dissolved-solids concentrations, the two most important human-related factors that affect nitrate concentrations of water once it has entered the aquifer relate to overall 


\section{A Natural factors}

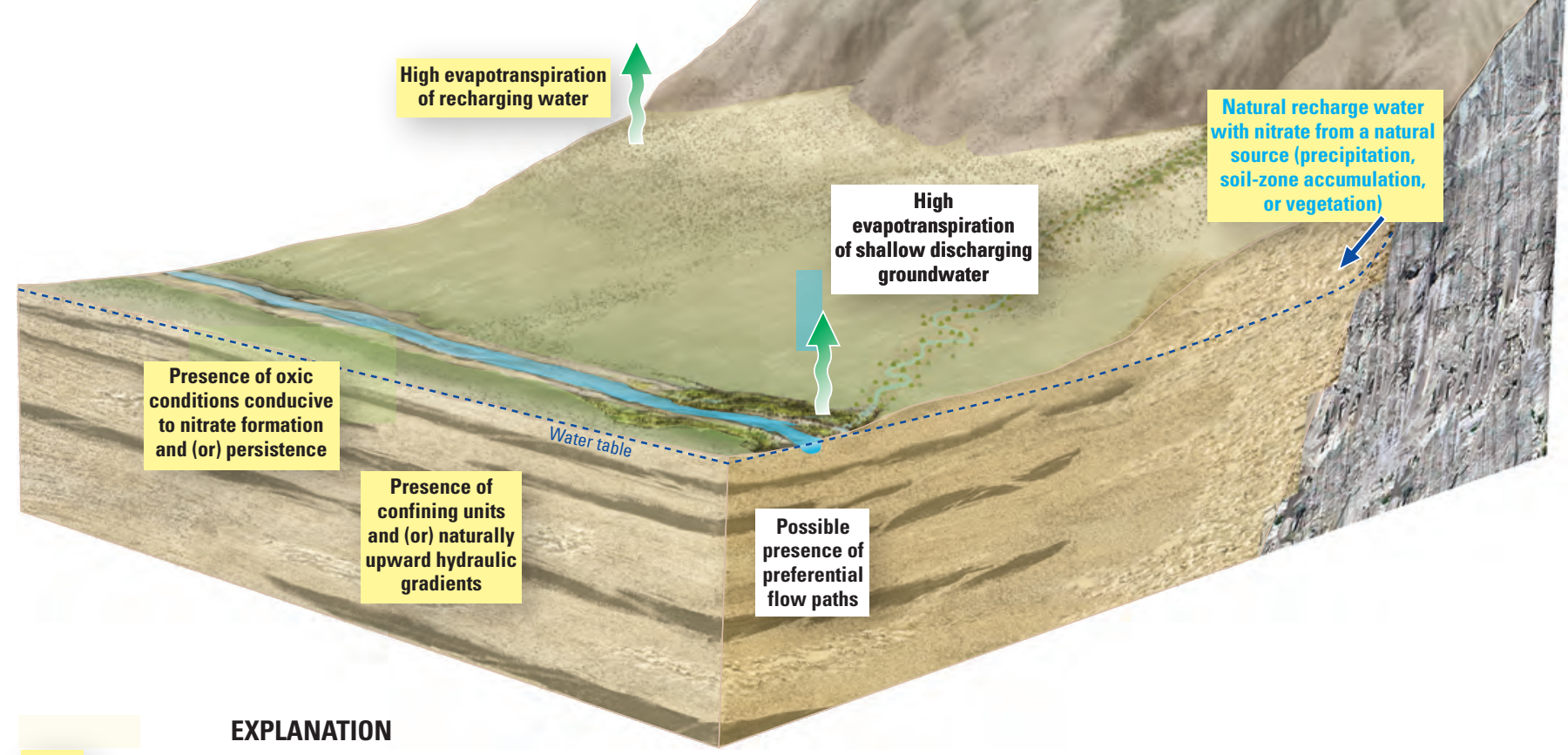

Contaminant source or hydrogeologic factor cited as being important in at least 20 percent of case-study basins

Contaminant source or hydrogeologic factor cited as being important in fewer than 20 percent of case-study basins

Contaminant sources are shown in blue text

Hydrogeologic factors are shown in black text

\section{B Human factors}

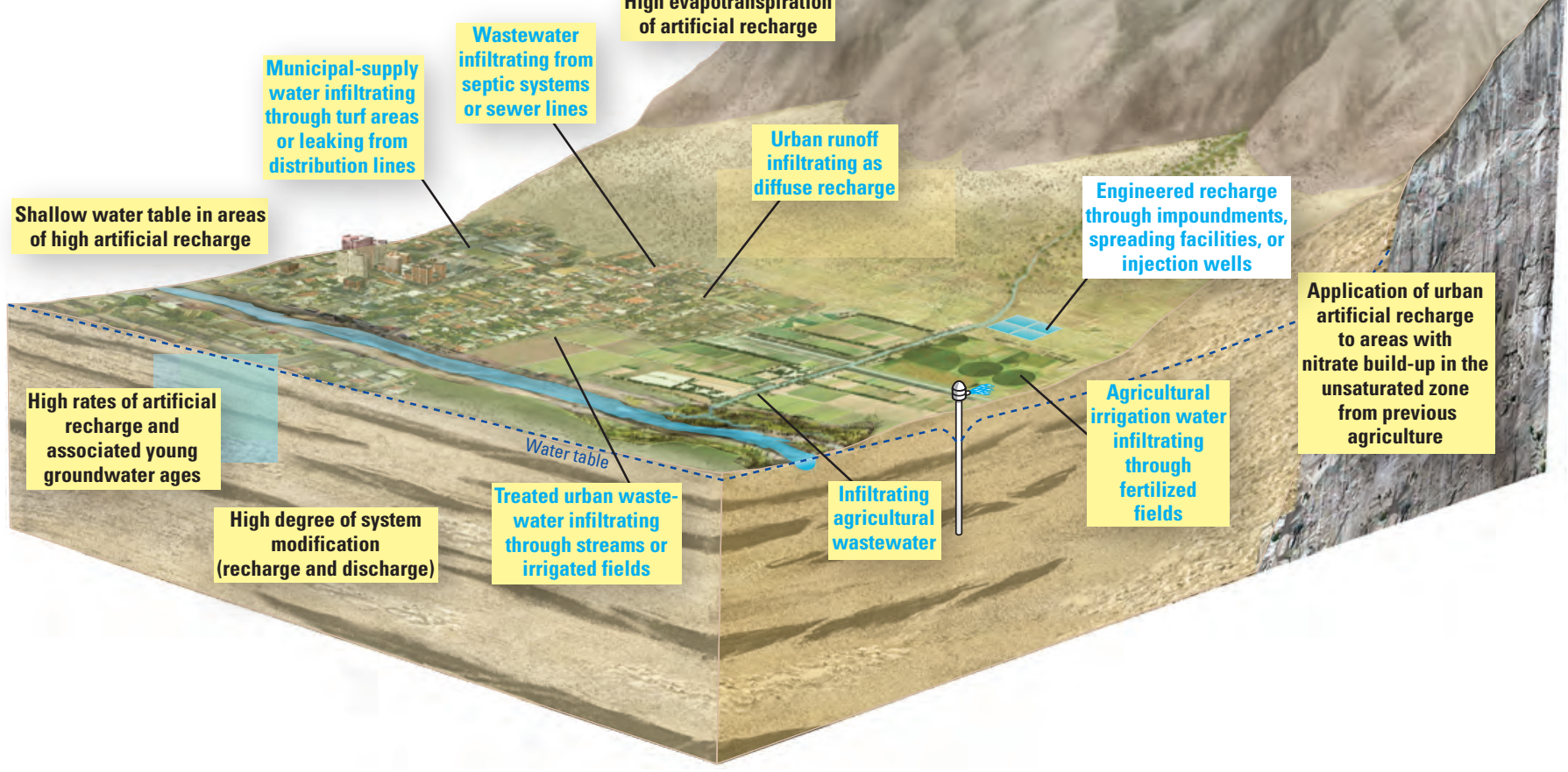

Figure 20. Conceptual model of major $A$, natural and $B$, human factors affecting the vulnerability of Southwestern basin-fill aquifers to contamination with nitrate. 
modification of the hydrologic system. In particular, the addition of a large quantity of artificial recharge to the aquifer and (or) the combined modification of the mechanisms and quantities of recharge and discharge can substantially affect rates of groundwater flow, directions of groundwater flow, and mixing between waters of varying source and (or) age, thereby transporting water with high nitrate concentrations horizontally and vertically to parts of the aquifer that would otherwise be unaffected.

\section{Well}

In most Southwestern basin-fill aquifers where nitrate concentrations are an issue, elevated concentrations have been observed primarily at shallow depths of the aquifer, which is consistent with most nitrate sources being at the land surface. Therefore, wells used for domestic or public supply generally do not appear to be particularly vulnerable to contamination with nitrate at concentrations above $5 \mathrm{mg} / \mathrm{L}$ under current aquifer conditions. However, the relative importance of hydrologic-system modification to the distribution of nitrate concentrations in some basins implies that higher-producing wells in areas of greater pumping stress could eventually be affected by any existing high-nitrate groundwater located nearby at shallow depths. Wells screened beneath confining units or in areas of generally upward vertical gradients are likely to be somewhat more protected from increasing nitrate concentrations.

\section{Contaminants with Primarily Natural Sources}

\section{Arsenic}

The conceptual model of major factors affecting the vulnerability of Southwestern basin-fill aquifers to contamination with arsenic is illustrated in figure 21 .

\section{Land Surface and Unsaturated Zone}

At or near the land surface, the primary natural factor important to the vulnerability of Southwestern basin-fill aquifers to contamination with arsenic is the presence of high-arsenic rocks or sediments that are contacted by recharging precipitation or surface water. Arsenic can be released to recharge water from these rocks or sediments either through dissolution or desorption.

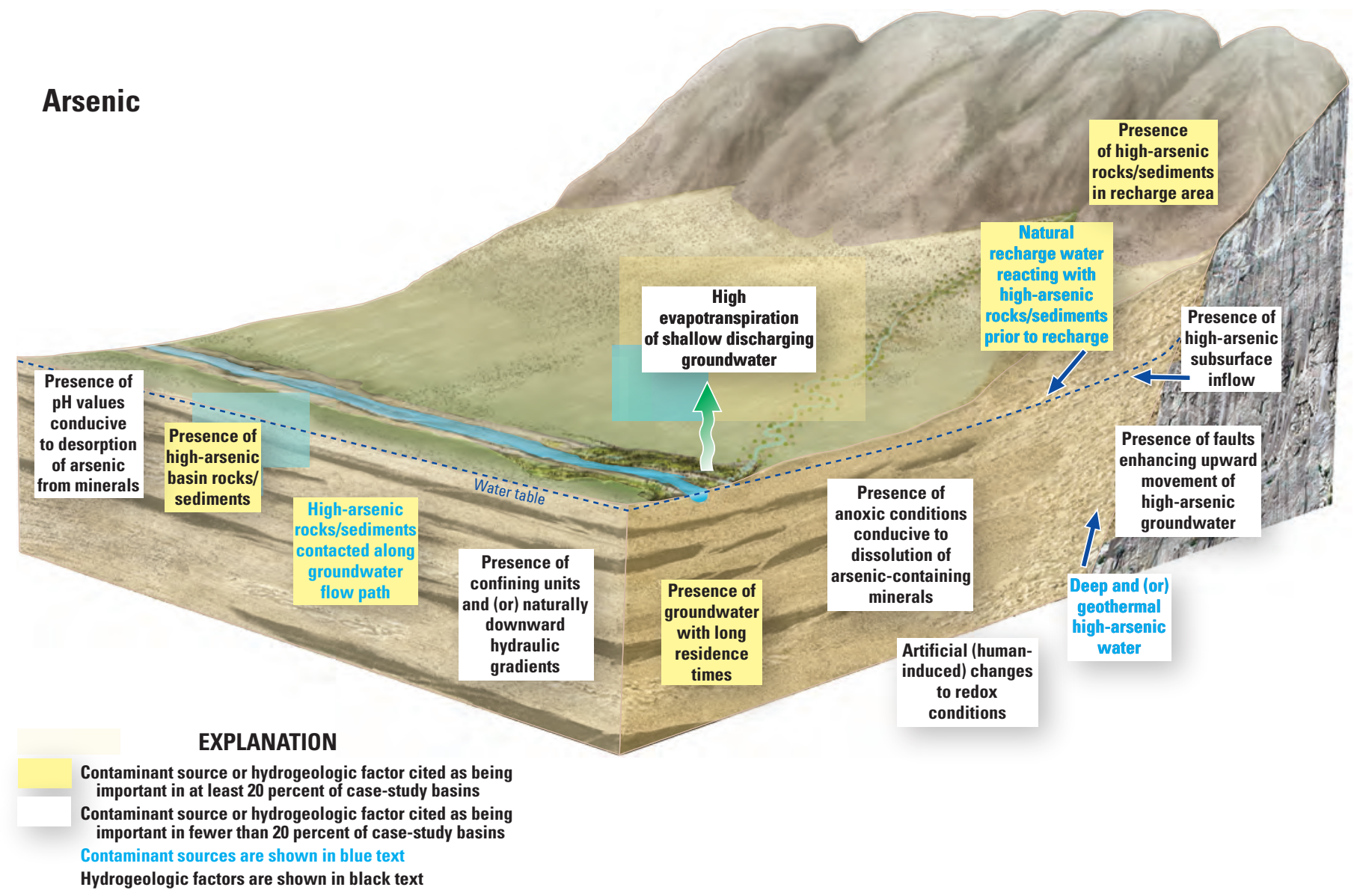

Figure 21. Conceptual model of major natural and human factors affecting the vulnerability of Southwestern basin-fill aquifers to contamination with arsenic. 


\section{Aquifer}

The most important factor affecting arsenic concentrations in water that has reached the aquifer is the presence of higharsenic rocks or sediments that are contacted by groundwater along a flow path. As at the land surface, the two main processes that release arsenic from aquifer sediments to groundwater are dissolution and desorption. The available studies in the case-study basins have documented cases where high $\mathrm{pH}$ values (greater than 8.0) have induced desorption of arsenic from iron hydroxides, where the presence of anoxic conditions have contributed to dissolution of iron hydroxides (with concurrent release of adsorbed arsenic), and where changes from anoxic to oxic conditions as a result of artificial recharge have likely resulted in dissolution of arsenic-containing sulfide minerals. However, a general lack of detailed studies of arsenic geochemistry in the case-study basins limits the conclusions that can be drawn about which of these processes and factors most commonly affect arsenic release from sediments in Southwestern alluvial basins. One contributing factor common to elevated arsenic concentrations in at least a few case-study basins is the presence of groundwater with long residence times.

\section{Well}

In most Southwestern basin-fill aquifers where arsenic concentrations are an issue and sufficient data are available to determine the distribution of arsenic with depth, elevated concentrations have been observed at most or all depths of the aquifer, perhaps partly because sources are not located only or primarily at the land surface but also in the subsurface. Observation of elevated arsenic concentrations (above $5 \mu \mathrm{g} / \mathrm{L}$ ) across a wide range of depths indicates that wells used for domestic or public supply can be vulnerable to contamination. The presence of confining units and modification of the aquifer system through changes to recharge and (or) discharge have not commonly been shown to substantially affect the distribution of elevated arsenic concentrations in the groundwater of Southwestern alluvial basins.

\section{Uranium}

The conceptual model of major factors affecting the vulnerability of Southwestern basin-fill aquifers to contamination with uranium is illustrated in figure 22 .

\section{Land Surface and Unsaturated Zone}

At or near the land surface, the presence of high-uranium rocks (such as granites) or sediments that are contacted by recharging precipitation or surface water is the primary natural factor important to the vulnerability of Southwestern basin-fill aquifers to contamination with uranium. Uranium can be released to recharge water from these rocks or sediments either through dissolution or desorption.
Aquifer

The most important factor affecting uranium concentrations in water that has reached the aquifer is the presence of high-uranium rocks or sediments that are contacted by groundwater along a flow path. As at the land surface, the two main processes that release uranium from aquifer sediments to groundwater are dissolution and desorption. The few available studies in SWPA case-study basins have documented cases where oxic conditions combined with relatively high alkalinity values have increased the mobility of available uranium by forming complexes that reduce and (or) inhibit adsorption to iron hydroxides, clays, or other materials. However, a general lack of detailed studies of uranium geochemistry in the casestudy basins limits the conclusions that can be drawn about the importance of these and other processes in affecting uranium release from sediments in Southwestern alluvial basins.

\section{Well}

In most Southwestern basin-fill aquifers where uranium concentrations are an issue, data are not sufficient to determine the distribution of uranium with depth. Therefore, the vulnerability of wells used for domestic or public supply and the potential importance of various factors in affecting the vertical distribution of elevated uranium concentrations cannot be confidently assessed.

\section{Contaminants with Primarily Human Sources}

\section{Volatile Organic Compounds}

The conceptual model of major factors affecting the vulnerability of Southwestern basin-fill aquifers to contamination with VOCs is illustrated in figure 23.

\section{Land Surface and Unsaturated Zone}

At or near the land surface, the primary human-related factors important to the vulnerability of Southwestern basinfill aquifers to contamination with VOCs are associated with urban land use. In particular, the most important sources appear to be urban point sources (such as landfills, leaky storage tanks, spills, and (or) improper disposal points in industrial, commercial, and (or) military settings) and chlorinated municipal-supply water infiltrating through irrigated turf areas or leaking from distribution pipes. Although detailed information on which VOCs are being used in what quantities and where generally is not available, these sources are known to be consistent with the most common types of VOCs detected in Southwestern basin-fill aquifers, which are THMs and chlorinated solvents followed by compounds related to gasoline. Another relatively common source of VOCs to Southwestern basin-fill aquifers is urban runoff infiltrating as diffuse recharge. Although mentioned for only a few case-study basins, the primary near-surface hydrogeologic factor affecting aquifer vulnerability with respect to VOCs is the presence of 


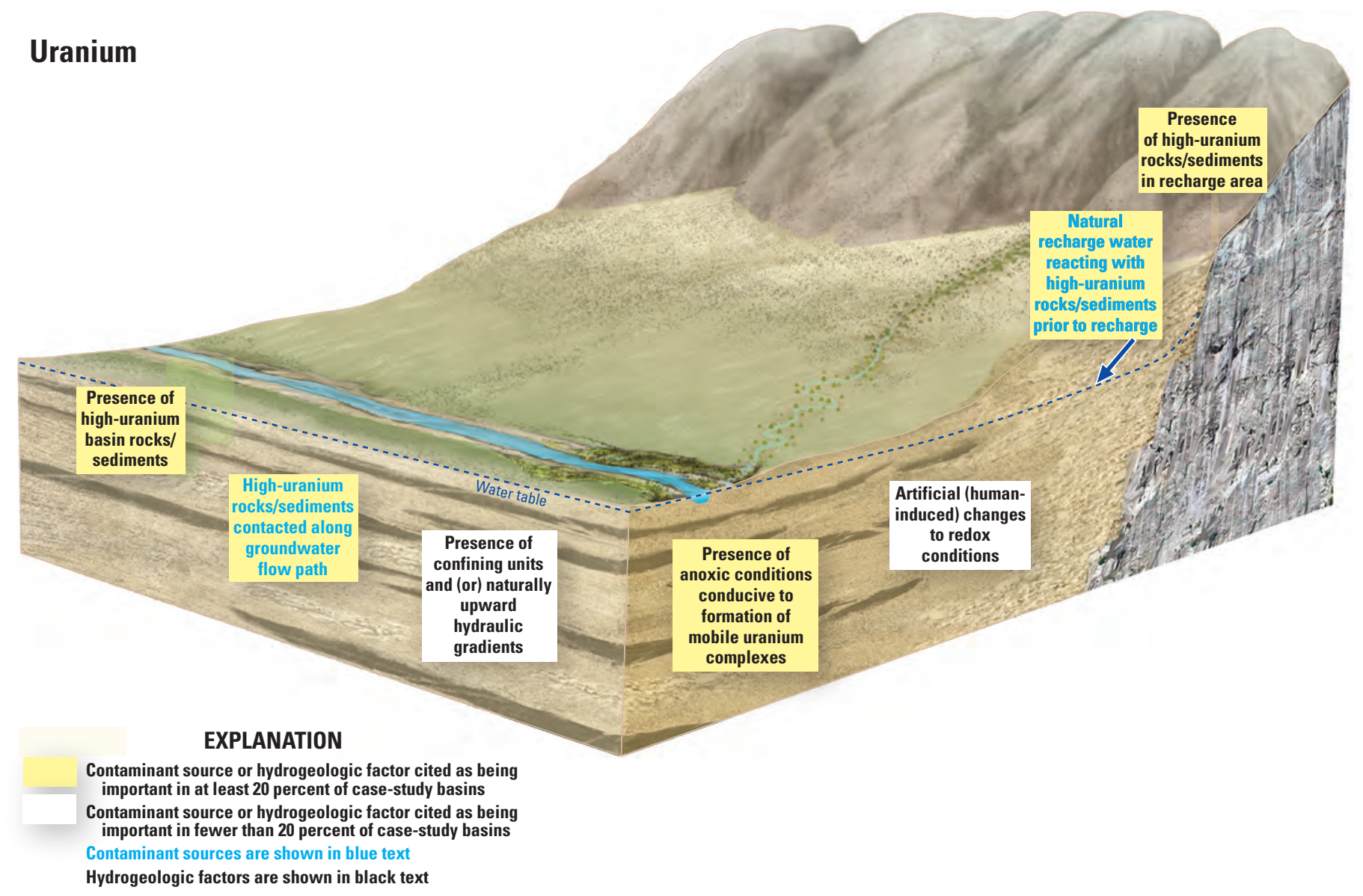

Figure 22. Conceptual model of major natural and human factors affecting the vulnerability of Southwestern basin-fill aquifers to contamination with uranium.

a shallow water table (thin unsaturated zone) in areas where artificial recharge occurs.

\section{Aquifer}

The most important factor affecting VOC detections in water that has reached the aquifer appears to be the natural redox conditions present. Oxic conditions are conducive to the degradation of some VOCs, such as many petroleum hydrocarbons, whereas anoxic conditions are conducive to the degradation of others, such as solvents and THMs. Another hydrogeologic factor of importance in the distribution of VOCs in groundwater is the primary direction of vertical gradients, which helps to determine the vulnerability of the deeper (used) aquifer to contamination. In several basins, naturally downward hydraulic gradients enhance transport of VOCs to deeper parts of the aquifer in some areas; however, in other areas or basins, the presence of confining units and (or) naturally upward hydraulic gradients act to protect the used part of the aquifer from downward migration of shallow groundwater having VOC detections.

The three most important human-related factors that affect VOC detections in water once it has entered the aquifer relate to overall modification of the hydrologic system. In particular, these factors are the addition of a large quantity of artificial recharge to the aquifer, the withdrawal of large quantities of groundwater through wells, and (or) the combined modification of the mechanisms and quantities of recharge and discharge. These factors can substantially affect rates of groundwater flow, directions of groundwater flow, and mixing between waters of varying source and (or) age, thereby transporting water with VOCs at detectable concentrations horizontally and vertically to parts of the aquifer that would otherwise be unaffected. The presence of wellbores that can act as preferential flow paths between different depths of the aquifer also appears to be a relatively common factor affecting the distribution of VOCs.

\section{Well}

In almost all Southwestern basin-fill aquifers where VOCs are an issue, compounds have been detected at most or all depths of the aquifer (although generally at very low concentrations) despite sources being located almost exclusively at the land surface. Observation of VOCs across a wide range of depths indicates that wells used for domestic or public supply can be vulnerable to contamination with at least low 


\section{Volatile organic compounds}

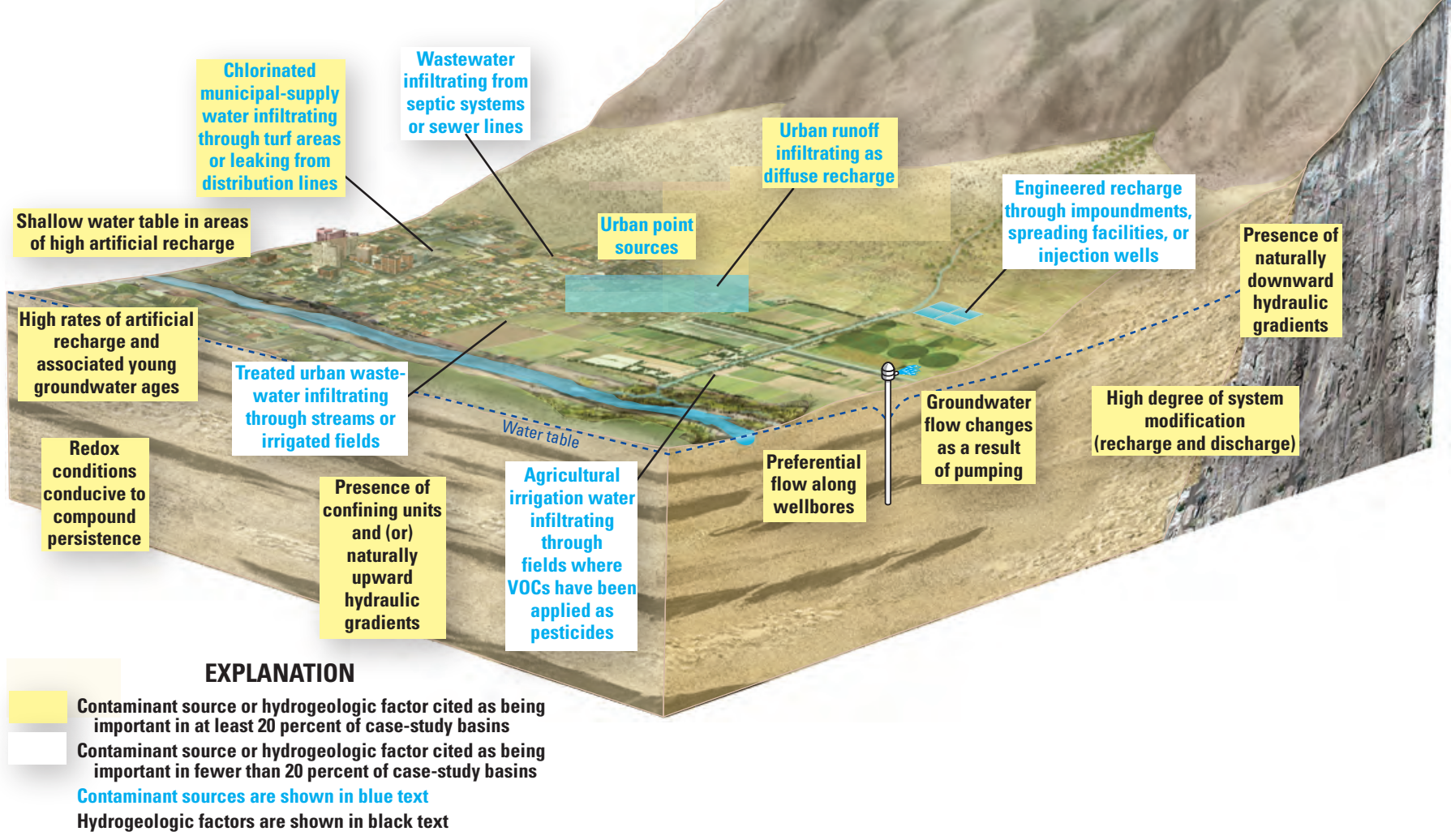

Figure 23. Conceptual model of major natural and human factors affecting the vulnerability of Southwestern basin-fill aquifers to contamination with volatile organic compounds.

concentrations of VOCs. On the basis of the importance of hydrologic-system modification to the distribution of VOCs, detections in deeper parts of the aquifer might reflect areas having large numbers of high-producing wells and large degrees of pumping stress. Such pumping centers are likely to be near urban areas, where the most VOC sources are present and where VOCs are commonly present at shallow aquifer depths. Wells screened beneath confining units or in areas of generally upward vertical gradients would be less likely to be affected by VOCs originating at the land surface.

\section{Pesticide Compounds}

The conceptual model of major factors affecting the vulnerability of Southwestern basin-fill aquifers to contamination with pesticide compounds is illustrated in figure 24 .

\section{Land Surface and Unsaturated Zone}

At or near the land surface, the primary human-related factors important to the vulnerability of Southwestern basinfill aquifers to contamination with pesticide compounds are associated with agricultural and urban land use. In particular, the most important source in Southwestern alluvial basins is excess irrigation water infiltrating from agricultural fields and (or) urban turf areas. The relatively coarse soils of low organic-carbon content that are typical of most locations in Southwestern alluvial basins are conducive to relatively fast transport of water through the soil zone with little opportunity for contaminants to partition or degrade. The quantities of particular pesticide compounds being applied to (and, consequently, available for transport from) agricultural fields has been estimated at the county scale (Thelin and Gianessi, 2000), but information on non-agricultural pesticide use is not available at this level of detail. Other relatively common sources of pesticides to Southwestern basin-fill aquifers are diffuse urban/non-agricultural runoff and urban wastewater infiltrating through streams to which the wastewater is released or through fields to which it is applied. Although mentioned for only a few case-study basins, the primary near-surface hydrogeologic factor affecting aquifer vulnerability with respect to pesticides is the presence of a shallow water table (thin unsaturated zone) in areas where artificial recharge occurs. 


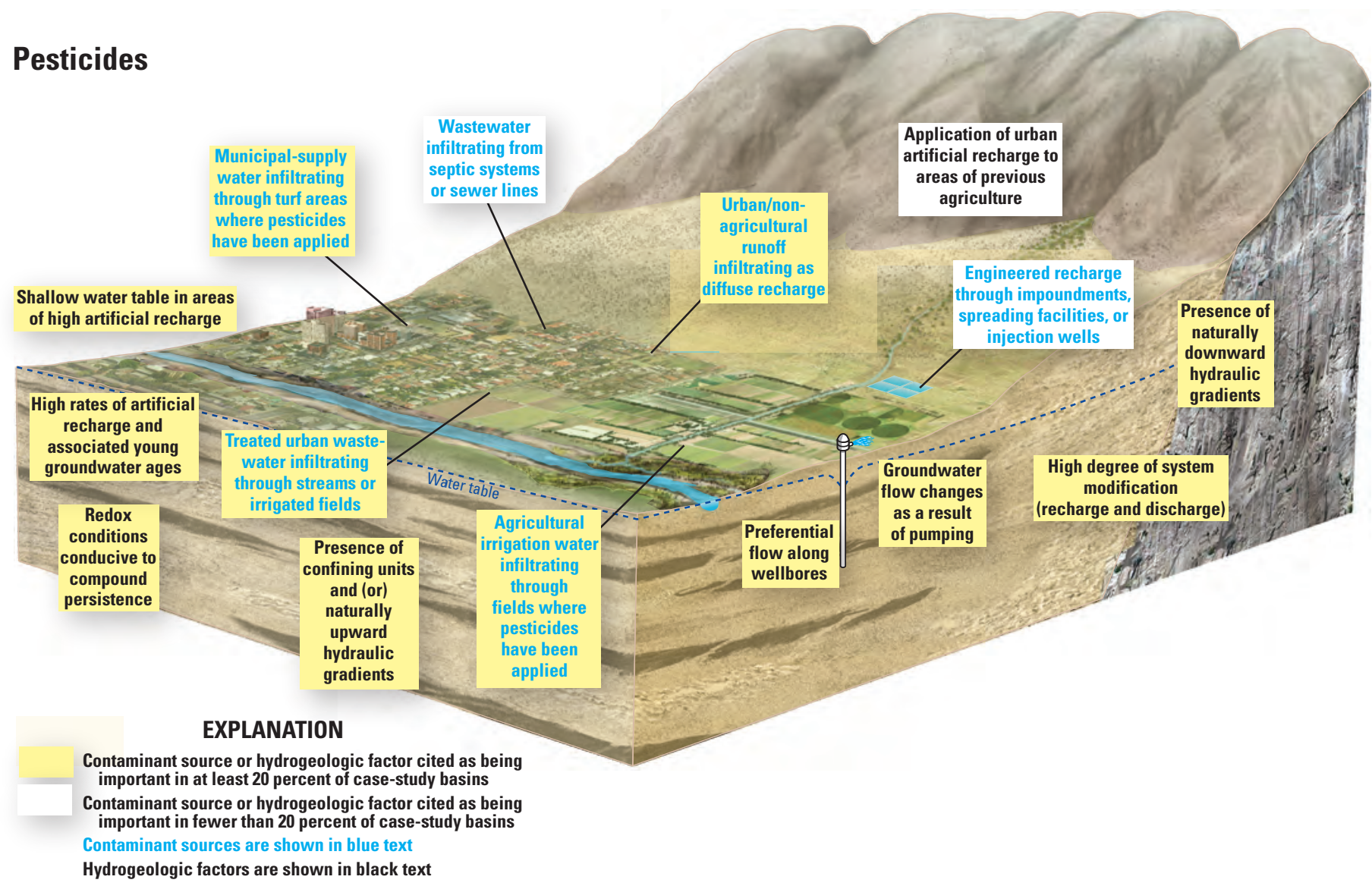

Figure 24. Conceptual model of major natural and human factors affecting the vulnerability of Southwestern basin-fill aquifers to contamination with pesticide compounds.

\section{Aquifer}

The most important factor affecting pesticide detections in water that has reached the aquifer appears to be the natural redox conditions present. Oxic conditions are conducive to the degradation of some pesticide compounds, whereas anoxic conditions are conducive to the degradation of others. Another hydrogeologic factor of importance in the distribution of pesticide compounds in groundwater is the primary direction of vertical gradients, which helps to determine the vulnerability of the deeper (used) aquifer to contamination. In several basins, naturally downward hydraulic gradients enhance transport of pesticide compounds to deeper parts of the aquifer in some areas; however, in other areas or basins, the presence of confining units and (or) naturally upward hydraulic gradients act to protect the used part of the aquifer from downward migration of shallow groundwater having pesticide detections.

The three most important human-related factors that affect pesticide detections in water once it has entered the aquifer relate to overall modification of the hydrologic system. In particular, these factors are the addition of a large quantity of artificial recharge to the aquifer, the withdrawal of large quantities of groundwater through wells, and (or) the combined modification of the mechanisms and quantities of recharge and discharge. These factors can substantially affect rates of groundwater flow, directions of groundwater flow, and mixing between waters of varying source and (or) age, thereby transporting water with pesticide compounds at detectable concentrations horizontally and vertically to parts of the aquifer that would otherwise be unaffected. The presence of wellbores that can act as preferential flow paths between different depths of the aquifer also appears to be a relatively common factor affecting the distribution of pesticides.

\section{Well}

In most Southwestern basin-fill aquifers where pesticides are an issue, compounds have been detected at most or all depths of the aquifer (although generally at very low concentrations) despite sources being located almost exclusively at the land surface. Observation of pesticides across a wide range of depths indicates that wells used for domestic or public supply can be vulnerable to contamination with at least low concentrations of pesticide compounds. On the basis of the importance of hydrologic-system modification to the distribution of pesticides, detections in deeper parts of the aquifer might reflect the presence of high-producing wells and areas of high pumping stress where pesticides present at shallow aquifer 
depths would tend to migrate downward. Wells screened beneath confining units or in areas of generally upward vertical gradients would be less likely to be affected by pesticide compounds originating at the land surface.

\section{Summary}

As part of the U.S. Geological Survey National WaterQuality Assessment (NAWQA) Program, the Southwest Principal Aquifer (SWPA) study is building a better understanding of the factors that affect water quality in basin-fill aquifers in the Southwestern United States by synthesizing the baseline knowledge of groundwater-quality conditions in 15 basins previously studied by the NAWQA Program. Resulting improvements in the understanding of the sources, movement, and fate of contaminants are assisting in the development of tools for use in assessing aquifer susceptibility and vulnerability. The SWPA study area includes four principal aquifers of the United States: the Basin and Range basin-fill aquifers in California, Nevada, Utah, and Arizona; the Rio Grande aquifer system in New Mexico and Colorado; and the Coastal Basin and Central Valley aquifer systems in California. About 46.6 million people live in the study area and rely heavily on goodquality groundwater supplies, accounting for about one quarter of the total withdrawals from all aquifers in the United States.

Similarities in the hydrogeology, land- and water-use practices, and water-quality issues for the basins within the SWPA study area allow for regional analysis. This report synthesizes available information summarized by the NAWQA Program into conceptual models of the primary natural and human factors commonly affecting groundwater quality with respect to selected contaminants, thereby helping to build a regional understanding of the susceptibility and vulnerability of basinfill aquifers to those contaminants. The conceptual models are intended in part to provide a foundation for subsequent development of regional-scale statistical models that relate specific groundwater-quality constituent concentrations or occurrence to natural and human factors. Regional-scale models and other decision-support tools that integrate aquifer characteristics, land use, and water-quality monitoring data will help water managers to estimate water-quality conditions in unmonitored areas, assess the sustainability of water resources for future supply, and develop cost-effective groundwater monitoring programs.

Synthesis of information from the 15 SWPA case-study basins indicates that although many general commonalities exist with respect to hydrogeology, climate, and other characteristics, multiple factors with the potential to substantially affect groundwater quality exhibit a broad range of conditions among the basins. Variation in the composition of bedrock in the hydrogeologic areas surrounding the case-study basins (which is a potential primary source of contaminants such as dissolved solids, arsenic, and uranium) is demonstrated by the range of less than 1 to 69 percent being covered by volcanic rocks, which have been associated with elevated concentrations of certain trace elements in groundwater in some parts of the Southwest. Variation in land use within the alluvial basins (which represents important sources of contaminants such as dissolved solids, nitrate, VOCs, and pesticide compounds) is demonstrated by the range of less than 1 to 61 percent of land use being agricultural and of 2 to 94 percent being urban, with population density ranging between 15 and 7,000 persons per square mile.

The general distribution, quantity, and mechanisms of groundwater recharge and discharge can be very important to aquifer vulnerability because they are related to such factors as how much water (and associated contaminant) is transported to the water table and at what locations, where groundwater flows from/to, and how fast groundwater travels. Among the 15 SWPA case-study basins, the dominant mechanism of recharge under natural conditions was consistently either mountain-front/mountain-block recharge at basin margins or stream loss (typically on valley floors); the dominant mechanism of discharge generally was evapotranspiration. However, the quantity of recharge under natural conditions ranged widely from 2,100 acre-ft/yr to 2.0 million acre-ft/yr for the basin as a whole. Artificial recharge sources resulting from development have increased the quantity of recharge in every case-study basin by as little as 11 percent to as much as 565 percent. The primary artificial recharge mechanism for many basins is infiltration of excess irrigation water (agricultural and (or) urban), but for at least one basin is engineered recharge. Under modern conditions, groundwater pumping from wells is a major discharge mechanism, ranging from about 26 to 100 percent of total discharge. On the basis of calculations using estimated aquifer dimensions, the typical residence time of groundwater within the "active" part of the basin-fill aquifers ranged from about 120 to 7,400 years under predevelopment conditions and from about 100 to 5,400 years under modern conditions.

General aquifer characteristics such as the thickness of the overlying unsaturated zone, the presence or absence of effective confining units, and the redox conditions can be very important to aquifer vulnerability because they exert some control over the quantity and distribution of water (and associated contaminants) reaching the aquifer, the depths to which contaminants are transported, and the persistence of contaminants within the aquifer, respectively. The unsaturated zone is less than $50 \mathrm{ft}$ thick over broad areas of some of the 15 case-study basins, whereas it exceeds $100 \mathrm{ft}$ in thickness across the majority of other basins. Some basins contain thick, extensive confining units that effectively inhibit downward vertical groundwater flow, whereas others have only relatively few thin, discontinuous clay layers that have a minimal effect on vertical flow. The case-study basins also vary in the extent of groundwater having oxic conditions and of groundwater having $\mathrm{pH}$ greater than 8 .

Synthesis of NAWQA data and published studies of groundwater quality in the 15 SWPA case-study basins allows for general conclusions to be drawn about which contaminants 
are of greatest concern and about factors relevant to aquifer vulnerability with respect to those contaminants. Differences in important natural and human-related characteristics among the 15 case-study basins (as described in the previous few paragraphs) are reflected in observed differences in the areal and vertical extent of individual contaminants in the basinfill aquifers above levels of concern and in the sources and hydrogeologic controls that have been documented to affect those contaminants. Groundwater contaminants common to many Southwestern basin-fill aquifers include contaminants with primarily natural sources (arsenic and uranium), primarily human sources (VOCs and pesticide compounds), and a combination of natural and human sources (dissolved solids and nitrate). For this report, these contaminants were investigated for sources and controls affecting their occurrence and distribution above specified levels of concern in groundwater of the case-study basins, and conceptual models of factors that are important to aquifer vulnerability with respect to those contaminants were subsequently formed.

Dissolved solids and nitrate are two contaminants that are commonly found in groundwater of Southwestern basin-fill aquifers and that have potentially important sources of natural and human origin. Dissolved-solids concentrations exceeding $500 \mathrm{mg} / \mathrm{L}$ are common across broad areas and depths of many Southwestern alluvial basins. With respect to natural sources, elevated concentrations are attributable primarily to reactive rocks and (or) sediments in aquifers and (or) their recharge areas, although saline water of deep and (or) geothermal origin is also a relatively common source. With respect to human sources, excess irrigation water infiltrating through agricultural fields is the primary contributor, although urban sources as a whole also can be particularly important. Agricultural and urban recharge have been noted to contribute appreciably to elevated dissolved-solids concentrations even in basins where the individual land use of interest accounts for only a small fraction of land use in the basin as a whole. Hydrogeologic factors most commonly affecting dissolved-solids concentrations include evapotranspiration of recharge (natural and artificial) and of shallow discharging groundwater, the presence of a shallow water table in areas of high artificial recharge, and substantial human modification of aquifer recharge and (or) discharge processes.

Nitrate concentrations exceeding $5 \mathrm{mg} / \mathrm{L}$ are common at shallow aquifer depths in either localized or broad areas of many Southwestern basin-fill aquifers. Although natural sources involving flushing of soil-zone accumulations of nitrate have been documented in a few basins, human sources are the primary contributors - in particular, excess irrigation water infiltrating through agricultural fields and urban turf areas where fertilizer has been applied and seepage of water from sewer and septic systems. Other common contributors are agricultural wastewater, urban wastewater applied to fields, and diffuse urban runoff. Similar to the case with dissolved solids, it appears that agricultural and urban recharge can contribute appreciably to elevated nitrate concentrations even in basins where the individual land use of interest covers a relatively small area. Hydrogeologic factors most commonly affecting nitrate concentrations include redox conditions in the aquifer, substantial human modification of aquifer recharge and (or) discharge processes, the presence of a shallow water table in areas of high artificial recharge, evapotranspiration of recharge (natural and artificial), and the presence of confining units and (or) upward gradients that help to protect deeper parts of the aquifer. Another factor of importance in several case-study basins is the occurrence of urban recharge in areas of previous agricultural activity.

Arsenic and uranium are two contaminants that are commonly found in groundwater of Southwestern basin-fill aquifers and that have primarily natural sources. Arsenic concentrations exceeding $5 \mu \mathrm{g} / \mathrm{L}$ are common to many Southwestern basin-fill aquifers across varying areal extents. Where data are sufficient to assess the vertical distribution of arsenic, elevated concentrations are observed at most or all aquifer depths. Elevated arsenic concentrations in groundwater are attributable primarily to high-arsenic rocks and (or) sediments within the aquifers and (or) their recharge areas. Although further investigation of the hydrogeologic factors resulting in release of arsenic from rocks and sediments in the Southwest is needed, available studies suggest that important factors include redox conditions, $\mathrm{pH}$, and the presence of groundwater with long residence times.

Uranium concentrations exceeding $15 \mu \mathrm{g} / \mathrm{L}$ are generally found in only localized areas of Southwestern alluvial basins. For most basins, investigations to date have not clearly established the range of depths where elevated uranium concentrations occur or the primary hydrogeologic factors causing release of uranium from its primary source, believed to be high-uranium rocks and (or) sediments within the aquifers and (or) their recharge areas. Available studies suggest that redox conditions might commonly play a role in the formation and persistence of mobile uranium complexes.

VOCs and pesticide compounds are two classes of contaminants that are regularly found in groundwater of Southwestern basin-fill aquifers and that have primarily human sources. VOC detections are common across broad areas and depths of many Southwestern alluvial basins and include primarily THMs and solvents. The main contributors of VOCs to groundwater are urban point sources (which can include landfills, leaky storage tanks, spills, and (or) improper disposal points in industrial, commercial, and (or) military settings) and chlorinated municipal-supply water infiltrating through irrigated yards/turf areas or leaking from distribution pipes. However, another relatively common contributor is diffuse urban runoff. Hydrogeologic factors most frequently affecting VOC detections include redox conditions in the aquifer, substantial human modification of aquifer recharge and (or) discharge processes, and the direction of natural vertical gradients that affect migration of VOCs to deeper parts of the aquifer. Available studies suggest that the presence of wellbores that can act as preferential flow pathways might also play a relatively frequent role in vertical migration of VOCs. 
Detections of pesticide compounds are common to many Southwestern basin-fill aquifers across varying areal extents and across most depths. Compounds detected typically include agricultural and non-agricultural herbicides. The primary contributor of pesticide compounds to groundwater is excess irrigation water infiltrating through agricultural fields and urban turf areas where pesticides have been applied, although diffuse urban runoff is another relatively common contributor. Hydrogeologic factors most frequently affecting detections of pesticide compounds include redox conditions in the aquifer, substantial human modification of aquifer recharge and (or) discharge processes, and the direction of natural vertical gradients that affect migration of compounds to deeper parts of the aquifer. Available studies suggest that the presence of wellbores that can act as preferential flow pathways might also play a relatively frequent role in vertical migration of pesticide compounds.

The conceptual models of factors that are important to the vulnerability of Southwestern basin-fill aquifers to contamination with respect to selected contaminants can be applied to vulnerability assessments and (or) modeling by indicating the types of variables that should be included in such efforts. More than 15 important factors in total were identified for the 6 contaminants included in this study. Several of these factors can be characterized using information available on a basin scale, which should allow application of assessments/models to sparsely studied alluvial basins. Among potential natural sources of contaminants, the ones that should be represented in assessments/models for at least one contaminant are the geologic composition of rocks and (or) sediments within the alluvial basin and in adjacent recharge areas (important for dissolved solids, arsenic, and uranium). The presence of geothermal water sources also is potentially important for dissolved solids and arsenic, and flushing of natural soil-zone or subsoil accumulations is potentially important for nitrate. Among human sources of contaminants, the ones that should be represented in assessments/models for at least one contaminant include agricultural sources, either individually or as a whole (important for dissolved solids, nitrate, and pesticide compounds), of which the most important is excess irrigation water infiltrating through fields. Sources that should be represented also include urban sources (important for dissolved solids, nitrate, VOCs, and pesticide compounds), either individually or as whole, depending on the contaminant and the objectives of the assessment/model.

Natural and human-related factors other than sources should be represented in assessments/models for most contaminants. Among natural hydrogeologic factors, the ones that should be represented for at least one contaminant are rates of evapotranspiration (important for dissolved solids and nitrate), presence/absence of confining units and (or) of upward versus downward natural hydraulic gradients (important for dissolved solids, nitrate, VOCs, and pesticide compounds), redox conditions in the aquifer (important for nitrate, VOCs, pesticide compounds, arsenic, and uranium), $\mathrm{pH}$ values in the aquifer (important for arsenic), and groundwater residence times (important for arsenic). Among human-related factors, the ones that should be represented are depth to water in areas of artificial recharge, contribution of artificial recharge to the overall basin budget, magnitude of pumping stresses, and well depth (all important for dissolved solids, nitrate, VOCs, and pesticide compounds); also, presence of urban recharge in areas of previous agricultural activity is important for nitrate.

The conceptual models presented in this report are intended to provide a general understanding of major factors that should be considered in broad-scale characterization of aquifer vulnerability and to help guide future efforts at statistical modeling of contaminant occurrence. The conceptual models should not be viewed as representing all potential factors important to the vulnerability of all Southwestern basin-fill aquifers to any class of contaminant. Not every potentially relevant factor was included in the analysis conducted for this report because of data limitations that did not allow for some factors to be adequately characterized, the occurrence of factors without sufficient variation among basins to assess their effects, and the intent to keep the conceptual models from becoming too complex for practical application. Finally, these conceptual models might not accurately capture all the most important factors determining aquifer vulnerability if the 15 SWPA case-study basins considered in the analysis are not truly representative of sources and processes present across all Southwestern basin-fill aquifers or if important factors in the individual case-study basins have not been accurately characterized in the current literature. Future advancements in the knowledge of factors affecting aquifer vulnerability within individual Southwestern basin-fill aquifers will allow for continuing improvement of regional vulnerability assessments.

Although the focus of this report was on areas where certain contaminants of interest have been detected in groundwater and on sources and factors that have contributed to the presence of those contaminants, the importance of the lack of contaminant detection in other areas where studies have been conducted should not be diminished. Areas where contaminant sources and (or) factors contributing to groundwater contamination are not present can be quite extensive in many Southwestern basin-fill aquifers and represent areas where land and water resources can still be managed to help prevent groundwater contamination from occurring. 


\section{References Cited}

Anderson, T.W., Freethey, G.W., and Tucci, P., 1992, Geohydrology and water resources of alluvial basins in south-central Arizona and parts of adjacent states: U.S. Geological Survey Professional Paper 1406-B, 67 p., 3 pl., scale 1:250,000.

Anning, D.W., Bauch, N.J., Gerner, S.J., Flynn, M.E., Hamlin, S.N., Moore, S.J., Schaefer, D.H., Anderholm, S.K., and Spangler, L.E., 2007, Dissolved solids in basin-fill aquifers and streams in the Southwestern United States: U.S. Geological Survey Scientific Investigations Report 2006$5315,336 \mathrm{p}$.

Anning, D.W., and Konieczki, A.D., 2005, Classification of hydrogeologic areas and hydrogeologic flow systems in the Basin and Range Physiographic Province, Southwestern United States: U.S. Geological Survey Professional Paper $1702,37 \mathrm{p}$.

Bohlke, J.K., Ericksen, G.E., and Revesz, K., 1997, Stable isotope evidence for an atmospheric origin of desert nitrate deposits in northern Chile and southern California, U.S.A.: Chemical Geology, v. 136, p. 135-152.

Brown, J.G., and Pool, D.R., 1989, Hydrogeology of the western part of the Salt River Valley, Maricopa County, Arizona: U.S. Geological Survey Water-Resources Investigations Report 88-4202, 5 sheets.

Burow, K.R., Dubrovsky, N.M., and Shelton, J.L., 2007, Temporal trends in concentrations of DBCP and nitrate in groundwater in the eastern San Joaquin Valley, California, USA: Hydrogeology Journal, v. 15, p. 991-1007.

Burow, K.R., Shelton, J.L., and Dubrovsky, N.M., 2008, Regional nitrate and pesticide trends in ground water in the eastern San Joaquin Valley, California: Journal of Environmental Quality, v. 37, no. 5, p. S-249-S-263.

California Department of Water Resources, 1993, SacramentoSan Joaquin Delta atlas: Sacramento, State of California Department of Water Resources, $121 \mathrm{p}$.

Campana, M.E., and Simpson, E.S., 1984, Groundwater residence times and recharge rates using a discrete-state compartment model and 14C data: Journal of Hydrology, v. 72, p. 171-185.

City of Albuquerque Public Works Department, 1997, City of Albuquerque water resources management strategyEvaluation of alternatives and strategy formulation: City of Albuquerque Public Works Department, Water Resources, February 1997, variously paged.

Coes, A.L., Gellenbeck, D.J., and Towne, D.C., 1999, Groundwater quality in the Sierra Vista Subbasin, Arizona, 199697: U.S. Geological Survey Water-Resources Investigations Report 99-4056, 50 p.
Coes, A.L., Gellenbeck, D.J., Towne, D.C., and Freark, M.C., 2000, Ground-water quality in the Upper Santa Cruz Basin, Arizona, 1998: U.S. Geological Survey Water-Resources Investigations Report 00-4117, 55 p. Available at http:// az.water.usgs.gov/pubs/WRIR00-4117intro.html.

Corkhill, E.F., Corell, Steve, Hill, B.M., and Carr, D.A., 1993, A regional groundwater flow model of the Salt River Valley_-Phase I: Phoenix Active Management Area hydrogeologic framework and basic data report, Arizona Department of Water Resources Modeling Report No. 6, 120 p., 2 pl.

Corkhill, F., Bota, L., Jahnke, P., Mason, D., and Hipke, W., 2004, Revised ground-water modeling results for the East Valley Water Forum Regional Water Planning Study, Arizona Department of Water Resources: accessed on October 13, 2006, at http://www.water.az.gov/dwr/content/ Publications/files/EVWF_revised_run1_12_2_04.pdf.

Davidson, E.S., 1973, Geohydrology and water resources of the Tucson Basin, Arizona: U.S. Geological Survey WaterSupply Paper 1939-E, 81 p.

Davisson, M.L., Hudson, G.B., Clark, J.F., Woodside, G., and Herndon, R., 2004, Final report on isotope tracer investigations in the Forebay of the Orange County groundwater basin: Lawrence Livermore National Laboratory UCRL-TR-201735, 115 p.

Dawson, B.J.M., Belitz, K., Land, M.T., and Danskin, W.R., 2003, Stable isotopes and volatile organic compounds along seven ground-water flow paths in divergent and convergent flow systems, southern California, 2000: U.S. Geological Survey Water-Resources Investigations Report 03-4059, 79 p. Available at http://water.usgs.gov/pubs/wri/wrir034059/.

DeSimone, L.A., 2009, Quality of water from domestic wells in principal aquifers of the United States, 1991-2004: U.S. Geological Survey Scientific Investigations Report 20085227, 139 p.

Eastern Municipal Water District, 2005, Eastern Municipal Water District urban water management plan 2005: accessed April 29, 2008, at http://www.emwd.org/news/pubs_uwmp. html.

Faunt, C.C., Hanson, R.T., and Belitz, K., 2009, Introduction, overview of hydrogeology, and textural model of California's Central Valley, in Faunt, C.C., ed., Groundwater availability of the Central Valley aquifer, California: U.S. Geological Survey Professional Paper 1766, p. 1-57.

Flint, L.E., and Flint, A.L., 2007, Regional analysis of groundwater recharge, in Stonestrom, D.A., Constantz, J., Ferré, T.P.A., and Leake, S.A., eds., Ground-water recharge in the arid and semiarid southwestern United States: U.S. Geological Survey Professional Paper 1703, p. 29-60. 
Focazio, M.J., Reilly, T.E., Rupert, M.G., and Helsel, D.R., 2002, Assessing ground-water vulnerability to contamination-Providing scientifically defensible information for decision makers: U.S. Geological Survey Circular 1224, 33 p. (Also available at http://pubs.usgs.gov/ circ/2002/circ1224/.)

Gelhar, L.W., Welty, C., and Rehfeldt, K.R., 1992, A critical review of data on field-scale dispersion in aquifers: Water Resources Research, v. 28, no. 7, p. 1955-1974.

Gilliom, R.J., Barbash, J.E., Crawford, C.G., Hamilton, P.A., Martin, J.D., Nakagaki, N., Nowell, L.H., Scott, J.C., Stackelberg, P.E., Thelin, G.P., and Wolock, D.M., 2006, The quality of our Nation's waters - Pesticides in the Nation's streams and ground water, 1992-2001: U.S. Geological Survey Circular 1291, 172 p.

Graham, R.C., Hirmas, D.R., Wood, Y.A., and Amrhein, C., 2008, Large near-surface nitrate pools in soils capped by desert pavement in the Mojave Desert, California: Geology, v. 36, no. 3, p. 259-262.

Helsel, D.R., and Hirsch, R.M., 1995, Statistical methods in water resources: U.S. Geological Survey Techniques of Water-Resources Investigations, book 4, chap. A3, 510 p.

Herndon, R.L., Brukner, D.B., and Sharp, G., 1997, Groundwater systems in the Orange County groundwater basin, Phase 1A Task 2.2 Report, prepared for the Santa Ana Watershed Project Authority, TIN/TOS Task Force: Orange County Water District, $12 \mathrm{p}$.

Hogan, J.F., Phillips, F.M., and Scanlon, B.R., eds., 2004, Groundwater recharge in a desert environment-The Southwestern United States: Washington, D.C., American Geophysical Union, Water Science and Application 9, 294 p.

Inland Empire Utilities Agency, 2005, 2005 regional urban water management plan: November 2005, v. II, accessed October 28, 2009, at http://www.ieua.org/news_reports/ docs/reports/2005UWMP/2005\%20UWMP/2005UrbanWat erManagementPlan.pdf.

Jurgens, B.C., Burow, K.R., Dalgish, B.A., and Shelton, J.L., 2008, Hydrogeology, water chemistry, and factors affecting the transport of contaminants in the zone of contribution of a public-supply well in Modesto, eastern San Joaquin Valley, California: U.S. Geological Survey Scientific Investigations Report 2008-5156, 78 p.

Lapham, W.W., Hamilton, P.A., and Myers, D.N., 2005, National Water-Quality Assessment Program-Cycle II Regional Assessments of Aquifers: U.S. Geological Survey Fact Sheet 2005-3013, 4 p.

Maupin, M.A., and Barber, N.L., 2005, Estimated withdrawals from principal aquifers in the United States, 2000: U.S. Geological Survey Circular 1279, 46 p.
McKinney, T.S., and Anning, D.W., 2009, Geospatial data to support analysis of water-quality conditions in basin-fill aquifers in the southwestern United States: U.S. Geological Survey Scientific Investigations Report 2008-5239, 16 p.

McMahon, P.B., and Chapelle, F.H., 2008, Redox processes and water quality of selected principal aquifer systems: Ground Water, v. 46, no. 2, p. 259-271.

Mendez, G.O., and Belitz, K., 2002, Identifying sources of base flow in the Santa Ana River, CA: American Water Resources Association 2002 summer specialty conference proceedings - Ground water/surface water interactions, $\mathrm{p}$. $567-572$.

Miller, J.A., 1999, Ground water atlas of the United StatesIntroduction and national summary: U.S. Geological Survey Hydrologic Atlas 730-A, 36 p.

Nolan, B.T., and Hitt, K.J., 2003, Nutrients in shallow ground waters beneath relatively undeveloped areas in the conterminous United States: U.S. Geological Survey WaterResources Investigations Report 2002-4289, 17 p.

Oak Ridge National Laboratory, 2005, LandScanTM Global Population Database, accessed September 2006, at http:// www.ornl.gov/landscan/.

Paschke, S.S., ed., 2007, Hydrogeologic settings and groundwater flow simulations for regional studies of the transport of anthropogenic and natural contaminants to public-supply wells-Studies begun in 2001: U.S. Geological Survey Professional Paper 1737-A, variously paged.

Paul, A.P., Seiler, R.L., Rowe, T.G., and Rosen, M.R., 2007, Effects of agriculture and urbanization on quality of shallow ground water in the arid to semiarid western United States, 1993-2004: U.S. Geological Survey Scientific Investigations Report 2007-5179, 56 p.

Plummer, L.N., Bexfield, L.M., Anderholm, S.K., Sanford, W.E., and Busenberg, E., 2004, Geochemical characterization of ground-water flow in the Santa Fe Group aquifer system, Middle Rio Grande Basin, New Mexico: U.S. Geological Survey Water-Resources Investigations Report 03-4131, 395 p.

Plummer, L.N., and Busenberg, E., 2006, Chapter 1 -Chlorofluorocarbons in aquatic environments, in International Atomic Energy Agency, Use of chlorofluorocarbons in hydrology-A guidebook: Vienna, International Atomic Energy Agency STI/PUB/1238, 277 p.

Reilly, T.E., Dennehy, K.F., Alley, W.M., and Cunningham, W.L., 2008, Ground-water availability in the United States: U.S. Geological Survey Circular 1323, 70 p.

Ruddy, B.C., Lorenz, D.L., and Mueller, D.K., 2006, Countylevel estimates of nutrient inputs to the land surface of the conterminous United States, 1982-2001: U.S. Geological Survey Scientific Investigations Report 2006-5012, 17 p. 
Smedley, P.L., and Kinniburgh, D.G., 2002, A review of the source, behaviour, and distribution of arsenic in natural waters: Applied Geochemistry, v. 17, p. 517-568.

Spencer, J., 2002, Natural occurrence of arsenic in Southwest ground water: Southwest Hydrology, May/June 2002, v. 1, no. 1, p. 14-15.

Stephens, D.B., Hsu, K.C., Prieksat, M.A., Ankeny, M.D., Blandford, N., Roth, T.L., Kelsey, J.A., and Whitworth, J.R., 1998, A comparison of estimated and calculated effective porosity: Hydrogeology Journal, v. 6, p. 156-165.

Stolp, B.J., 2007, Hydrologic setting and ground-water flow simulations of the Salt Lake Valley Regional Study Area, Utah, section 2, in Paschke, S.S., ed., Hydrogeologic settings and ground-water flow simulations for regional studies of the transport of anthropogenic and natural contaminants to public-supply wells - studies begun in 2001: U.S. Geological Survey Professional Paper 1737-A, p. 2-1 -2-22.

Stonestrom, D.A., Constantz, J., Ferré, T.P.A., and Leake, S.A., eds., 2007, Ground-water recharge in the arid and semiarid Southwestern United States: U.S. Geological Survey Professional Paper 1703, 414 p.

Thelin, G.P., and Gianessi, L.P., 2000, Method for estimating pesticide use for county areas of the conterminous United States: U.S. Geological Survey Open-File Report 00-250, $62 \mathrm{p}$.

Thiros, S.A., and Manning, A.H., 2004, Quality and sources of ground water used for public supply in Salt Lake Valley, Salt Lake County, Utah, 2001: U.S. Geological Survey Water-Resources Investigations Report 03-4325, 95 p.

Thiros, S.A., Bexfield, L.M., Anning, D.W., and Huntington, J.M., eds., 2010, Conceptual understanding and groundwater quality of selected basin-fill aquifers in the Southwestern United States: U.S. Geological Survey Professional Paper 1781, 288 p.

Ulmer-Scholle, D.S., 2010, Where is uranium found?: accessed February 3, 2010, at http://geoinfo.nmt.edu/ resources/uranium/where.html.
U.S. Environmental Protection Agency, 2009, National primary drinking water regulations: accessed November 2009 at http://www.epa.gov/safewater/contaminants/index. html.

U.S. Geological Survey, 2003a, Principal aquifers, in National Atlas of the United States of America, 1 sheet, accessed May 6, 2008, at http://nationalatlas.gov/mld/aquifrp.html.

U.S. Geological Survey, 2003b, Multi-Resolution Land Characteristics (MRLC) Consortium, National Land Cover Database (NLCD 2001), accessed May 17, 2010 at http:// www.mrlc.gov/.

U.S. Geological Survey, 2008, Water use in the United States, 2000 data for counties: accessed May 6, 2008, at http:// water.usgs.gov/watuse/.

Walvoord, M.A., Phillips, F.M., Stonestrom, D.A., Evans, R.D., Hartsough, P.C., Newman, B.D., and Striegl, R.G., 2003, A reservoir of nitrate beneath desert soils: Science, v. 302, no. 5647, p. 1021-1024.

Walvoord, M.A., and Scanlon, B.R., 2004, Hydrologic processes in deep vadose zones in interdrainage arid environments, in Hogan, J.F., Phillips, F.M., and Scanlon, B.R., eds., Groundwater recharge in a desert environmentThe Southwestern United States: Washington, D.C., American Geophysical Union, Water Science and Application 9, p. 15-28.

Welch, A.H., Helsel, D.R., Focazio, M.J., and Watkins, S.A., 1999, Arsenic in ground water supplies of the United States, in Calderon, R.L., Abernathy, C.O., and Chapelle, W.R., eds., Arsenic exposure and health effects: New York, Elsevier Science, p. 9-17, available at http://water.usgs.gov/ nawqa/trace/pubs/segh1998/.

Welch, A.H., Watkins, S.A., Helsel, D.R., and Focazio, M.J., 2000, Arsenic in ground-water resources of the United States: U.S. Geological Survey Fact Sheet 063-00, 4 p.

Wildermuth Environmental, Inc., 2000, TIN/TDS Phase 2A: Tasks 1 through 5, TIN/TDS study of the Santa Ana Watershed, Technical Memorandum, July 2000.

Williamson, A.K., Prudic, D.E., and Swain, L.A., 1989, Ground-water flow in the Central Valley, California: U.S. Geological Survey Professional Paper 1401-D, 127 p.

Woodside, G., and Westropp, M., 2009, Orange County Water District groundwater management plan 2009 update: accessed January 8, 2010, at http://www.ocwd.com/ Publications---Newsletters/ca-43.aspx.

Zogorski, J.S., Carter, J.M., Ivahnenko, T., Lapham, W.W., Moran, M.J., Rowe, B.L., Squillace, P.J., and Toccalino, P.L., 2006, Volatile organic compounds in the Nation's ground water and drinking-water supply wells: U.S. Geological Survey Circular 1292, 101 p. 



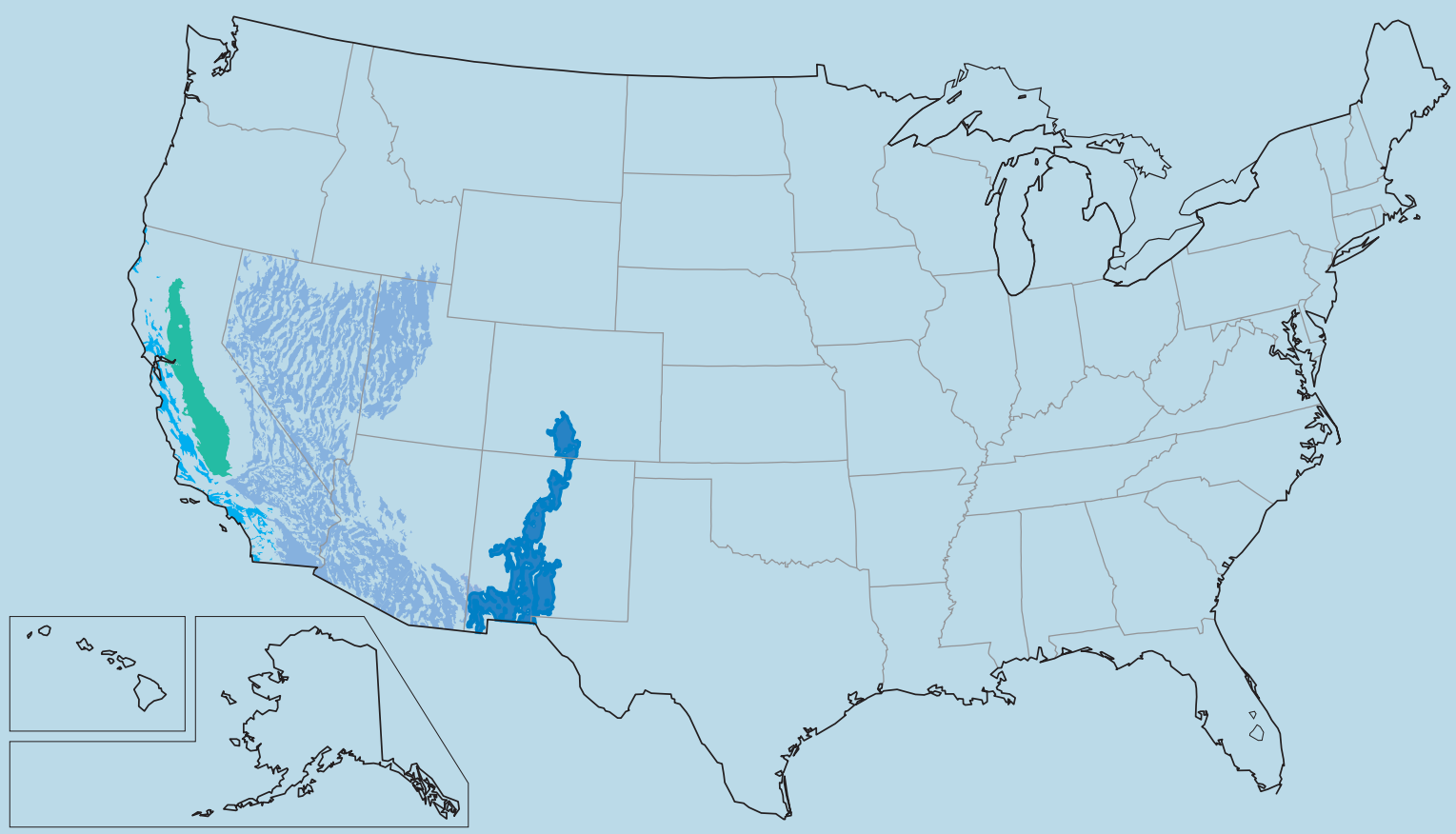

Southwest Principal Aquifers-Includes (from left to right) California Coastal Basin aquifers, Central Valley aquifer system, Basin and Range basin-fill aquifers, and Rio Grande aquifer system 